\author{
Universidade de São Paulo \\ Escola de Artes, Ciências e Humanidades \\ Programa de Pós-Graduação em Têxtil e Moda
}

Welton Fernando Zonatti

Estudo interdisciplinar entre reciclagem têxtil e o design: avaliação de compósitos produzidos com fibras de algodão 


\author{
Universidade de São Paulo \\ Escola de Artes, Ciências e Humanidades \\ Programa de Pós-Graduação em Têxtil e Moda
}

Welton Fernando Zonatti

\title{
Estudo interdisciplinar entre reciclagem têxtil e o design: avaliação de compósitos produzidos com fibras de algodão
}

Dissertação apresentada na Escola de Artes, Ciências e Humanidades da Universidade de São Paulo para obtenção do grau de Mestre em Ciências, Programa de Pós Graduação em Têxtil e Moda.

Linha de pesquisa: Materiais e Processos Têxteis

Orientadora: Prof ${ }^{a}$ Dra Júlia Baruque Ramos 
Autorizo a reprodução e divulgação total ou parcial deste trabalho, por qualquer meio convencional ou eletrônico, para fins de estudo e pesquisa, desde que citada a fonte.

Zonatti, Welton Fernando

Estudo interdisciplinar entre reciclagem têxtil e o design : avaliação de compósitos produzidos com fibras de algodão / Welton Fernando Zonatti ; orientadora Júlia Baruque Ramos. São Paulo, 2012.

$178 \mathrm{f}$. : il.

Dissertação (Mestrado em Ciências) - Programa de PósGraduação em Têxtil e Moda, Escola de Artes, Ciências e Humanidades da Universidade de São Paulo.

1. Tecidos (Indústria têxtil). 2. Fibras têxteis. 3. Algodão. 4. Materiais compósitos de fibras. 5. Resíduos sólidos - Reciclagem. 6. Fios (Indústria têxtil). 7 . Tecnologia têxtil. I. Ramos, Júlia Baruque, orient. II. Título. 


\section{AGRADECIMENTOS}

Quero agradecer imensamente todas as pessoas envolvidas neste trabalho, diretamente ou indiretamente. Venho agradecer, principalmente, a minha orientadora, Profa. Dra. Júlia Baruque Ramos, pela paciência, confiança e pela amizade que criamos no decorrer do tempo.

Agradeço também à minha família, meu pai Edson Antonio, minha mãe Teresa e meu irmão Wellington por estarem comigo sempre que necessário.

Agradeço ao meu amigo e companheiro inseparável, Júnior Marques, por estar ao meu lado nos momentos mais difíceis e nos mais incríveis.

Agradeço aos amigos maravilhosos que estiveram comigo nesta caminhada, em especial Bárbara Maria Gama Guimarães, Célia Regina da Costa, Camila Calado Vicente e Flávia Maciel Ribeiro Costa.

Agradeço também a CAPES (Coordenação de Aperfeiçoamento de Pessoal de Nível Superior), ao corpo técnico dos laboratórios multidisciplinares da EACH/USP e ao corpo docente da Universidade de São Paulo, em especial a Profa. Dra. Regina Aparecida Sanches, Profa. Dra. Maria Silvia Maria Barros de Held, Prof. Dr. Antonio Takao Kanamuru, Prof. Dr. Maurício Campos Araújo, Profa. Dra. Cláudia Regina Garcia Vicentini, Prof. Dr. Edson Leite e Prof. Dr. Eneus Trindade Barreto Filho. 
Sim! Conheço minha origem!

Insaciável como a chama

Ardo e me consumo.

Luz se torna tudo que pego.

Carvão, tudo que deixo:

Flama sou, certamente.

Friedrich Nietzsche 


\section{RESUMO}

ZONATTI, W. F. Estudo interdisciplinar entre reciclagem têxtil e o design: avaliação de compósitos produzidos com fibras de algodão. 2013. 178 p.

Dissertação (Mestrado) - Escola de Artes, Ciências e Humanidades, Universidade de São Paulo, São Paulo, 2013.

Visando o gerenciamento dos artigos têxteis advindos do descarte doméstico e dos refugos gerados nos processos de fabricação, a reciclagem e a reutilização surge como uma resposta emergencial aos problemas ambientais do setor de têxtil e moda.

O presente estudo teve como principais objetivos realizar uma revisão bibliográfica sobre técnicas de reuso e reciclagem de têxteis, principalmente das fibras de algodão, bem como temas relacionados à ecologia industrial, ao design de moda e ao eco-design. Na sua parte experimental também visou realizar ensaios de microscopia e de determinação de regain da fibra de algodão, bem como ensaios de tração, alongamento e microscopia em compósitos produzidos com três diferentes tipos de resinas termorrígidas (epóxi, poliéster ortoftálico e poliuretano) reforçadas com fibras têxteis de algodão, sugestão possível para a diminuição dos refugos têxteis em aterros sanitários. Para tais compósitos foram apontadas aplicações no setor de moda.

Conclui-se que os compósitos produzidos a partir de resíduos têxteis poderiam trazer benefícios ao meio-ambiente, pois além de possuírem atribuições como resistência e coesão, podem ser destinados à área de moda, entre outras áreas, pelos atributos visuais que proporcionam. Assim, são capazes de suprir necessidades específicas de consumo do mercado, ávido por novidades, bem como de suprir a demanda por estudos de novos materiais no setor de têxtil e moda, que carece de bibliografia especifica que reúna uma análise técnica e estética abrangendo todas as fases produtivas de materiais, processos, criação e design.

Palavras-chave: têxtil; reciclagem; reutilização; fibras de algodão; moda; design; compósitos; resina termofixa. 


\begin{abstract}
ZONATTI, W. F. Interdisciplinary study between recycling and design: evaluation of composites produced with cotton fibers. 2013. $178 \mathrm{p}$. Dissertação (Mestrado) - Escola de Artes, Ciências e Humanidades, Universidade de São Paulo, São Paulo, 2013.

Aiming management of textiles coming from household waste and scrap generated in the manufacturing processes, recycling and reuse arise as emergency responses to the environmental problems of the textile and fashion industry.
\end{abstract}

The present study main objectives were to perform an interdisciplinary literature review focused on techniques of reuse and recycling of textiles, mainly cotton fibers, as well as topics related to industrial ecology, the fashion design and eco design. On his experimental part it also aimed to carry out tests of microscopy and regain determination of cotton fibers as well as microscopy, tensile and elongation tests in composites made with three different types of thermoset resins (epoxy, polyester orthophthalic and polyurethane) reinforced with textile cotton fibers, configuring possible suggestion for the reduction of textile waste in landfills. For applications such composites were pointed in the fashion sector.

It is possible to conclude that the composites made from textile waste could bring benefits to the environment, because besides possessing strength and cohesion functions, they could be assigned to fashion design field from the visual attributes they provide. Thus, they are able to supply specific needs of the consumer market, eager for news, and to furnish the demand for studies of new materials in the textile and fashion sectors, which lacks specific bibliography that bring together aesthetic and technical analysis covering all production phases of materials, processes, creation an design.

Keywords: Textile; recycling, reuse, cotton fibers, fashion, design, composites, thermoset resin. 


\section{LISTA DE TABELAS}

Tabela 2.1. Benchmark global (processo comparativo entre dois ou mais sistemas) da instituição Werner International.. 7

Tabela 2.2. Principais características da fibra de algodão no que tange o meio ambiente. 10

Tabela 2.3. Influenciadores e motivações no momento da compra.

Tabela 2.4. Evolução histórica no estudo da Ecologia Industrial e seus principais autores.

Tabela 2.5. Exemplo de aplicação de Produção Mais limpa na indústria têxtil.. 30

Tabela 2.6. Comparação dos resultados e variáveis de estudos que realizaram a ACV para uma calça jeans. .36

Tabela 2.7. Triagem e destinação dada aos têxteis do Reino Unido por meio de entidades como a Oxfam e a Wastesave.

Tabela 2.8. Uso dos Processos Produtivos. 86

Tabela 2.9. Princípios amplos de apoio a boas práticas. .87

Tabela 4.1. Propriedades da resina epóxi BVR 222 e endurecedor BVE 0101

Tabela 4.2. Propriedades da resina poliéster ortoftálico Arazyn 1.0...... 120

Tabela 4.3. Propriedades da resina poliuretano Poly-Optic 1411 121

Tabela 4.4. Valores aproximados de tenacidade $\left(\sigma_{p}\right)$ e do módulo de Young $(E)$ para alguns materiais 129

Tabela 4.5. Resultados obtidos em dinamômetro com as resinas epóxi, de poliéster e de poliuretano puras e reforçadas com fibras de algodão provenientes de tecido denim. .130

Tabela 4.6. Comparação de resistências (Módulo de Young) entre diferentes materiais. 131

Tabela 8.1. Valores referentes à Carga Máxima (N), Tenacidade (MPa), Extensão de Ruptura e Módulo (MPa) das amostras produzidas com resina epóxi. 168

Tabela 8.2. Valores referentes à Carga Máxima (N), Tenacidade (MPa), Extensão de Ruptura e Módulo (MPa) das amostras produzidas com resina epóxi e reforçadas com fibras de algodão. 169 
Tabela 8.3. Valores referentes à Carga Máxima $(\mathrm{N})$, Tenacidade (MPa), Extensão de Ruptura e Módulo (MPa) das amostras produzidas com resina de poliéster pura com média. 170

Tabela 8.4. Valores referentes à Carga Máxima (N), Tenacidade (MPa), Extensão de Ruptura e Módulo (MPa) das amostras produzidas com resina de poliéster e reforçada com fibras de algodão. 171

Tabela 8.5. Valores referentes à Carga Máxima $(\mathrm{N})$, Tenacidade (MPa), Extensão de Ruptura e Módulo (MPa) das amostras produzidas com resina de poliuretano e reforçada com fibras de algodão. 172

Tabela 8.5. Valores referentes à Carga Máxima $(\mathrm{N})$, Tenacidade (MPa), Extensão de Ruptura e Módulo (MPa) das amostras produzidas com resina de poliuretano pura. 


\section{ÍNDICE DE FIGURAS}

Figura 2.1. Capulho de algodão 8

Figura 2.2. A planta linho logo depois de colhida e depois de seca, própria para a extração das fibras

Figura 2.3. Quadro a óleo do pintor francês Claude Monet intitulado "Femmes au jardin" (1866).

Figura 2.4. Exemplo de utilização de referências passadas na moda 15

Figura 2.5. Exemplo da rápida absorção de tendências pelo magazine Zara...... 19

Figura 2.6. Diferenças de preços entre calças jeans ecológicas e as convencionais. .22

Figura 2.7. Controle de final de tubo. 23

Figura 2.8. As bases primárias da ecologia industrial. .27

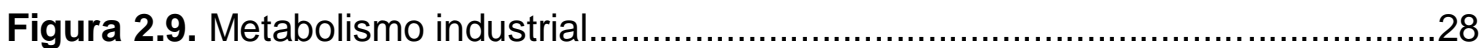

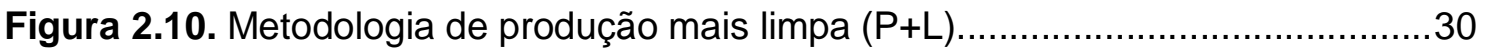

Figura 2.11. Esquema simplificado do conceito de Ciclo de Vida dos produtos

Figura 2.12. Exemplos de reutilização de tecidos. 40

Figura 2.13. Refugos têxteis encontrados nas ruas do bairro do Bom Retiro .50

Figura 2.14. Fluxograma atual do destino dado aos refugos têxteis no bairro do Bom Retiro. 50

Figura 2.15. Fluxograma do destino dado aos refugos têxteis no bairro do Bom Retiro após a implantação do projeto. .51

Figura 2.16. Fluxograma para desfibragem de resíduos têxteis: fase anterior a uma nova fiação. 54

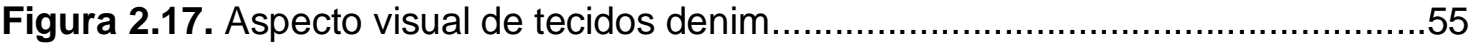

Figura 2.18. Fiação das fibras virgens de algodão...............................................56

Figura 2.19. Tipos de tecidos que podem ser reciclados...........................................59

Figura 2.20. Ciclo de análise Design Sustentável para a maximização da reutilização e reciclagem de vestuário descartado

Figura 2.21. Exemplos de produtos de moda ecologicamente 
corretos. .65

Figura 2.22. Coleção do estilista Gary Harvey. 66

Figura 2.23. Jeanswear ecologicamente corretos. 67

Figura 2.24. Acessórios de moda ecologicamente corretos de marcas brasileiras.

Figura 2.25. Acessórios de moda ecologicamente corretos de marcas estrangeiras

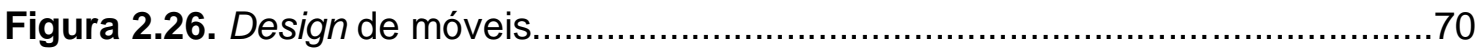

Figura 2.27. Modos de aplicação dos retalhos na decoração.........................................71

Figura 2.28. Arranjos típicos de fibras em cada camada de

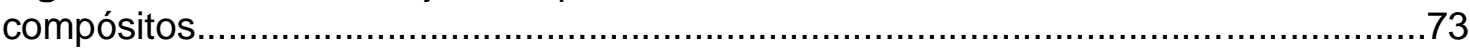

Figura 2.29. Tipos de materiais compósitos..........................................................74

Figura 2.30. Módulos de Young de vários tipos de materiais em $\mathrm{GN} / \mathrm{m}^{2}$ ou $\mathrm{GPa}$. .75

Figura 2.31. Óculos produzidos com material compósito: cabelos e resina vegetal. .77

Figura 2.32. Diferentes estilos de croquis................................................................. 82

Figura 3.1. Contextura do tecido chiffon de poliéster com aumento de 51

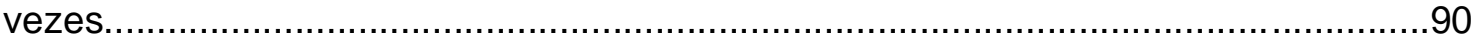

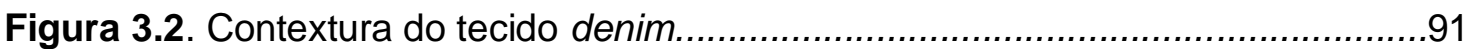

Figura 3.3. Exemplo de fixação de amostra longitudinal de fibra em moldura de cartolina 92

Figura 3.4. Sistema Video Analyser 2000 code 250 (Mesdan, Itália) .92

Figura 3.5. Encapsulamento do fio de algodão 93

Figura 3.6. Retângulos de cartolina branca de $7 \times 18 \mathrm{~mm}$, vazados 94

Figura 3.7. Fio de algodão encapsulado para ser cortado transversalmente obtendo fatias para as análises microscópicas

Figura 3.8. Micrôtomo semi-automatizado rotacional (Leica, modelo RM 2245,

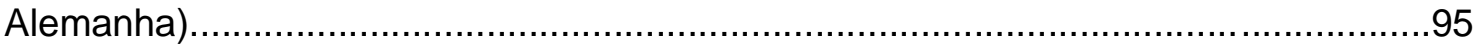

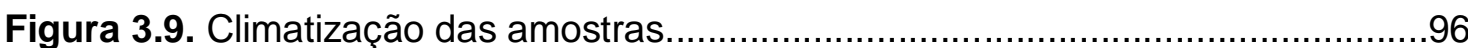

Figura 3.10. Forma de plástico (modelo Bioprática, Plasvale, Brasil) e resíduos têxteis acondicionados ao fundo. 100 
Figura 3.11. Serra de fita profissional (Ferrari, modelo AAS1070001, Brasil) utilizada para fatiar as "placas" de compósitos em tiras (amostras)......................................101

Figura 3.12. Corpo de prova de compósito. 101

Figura 3.13. Dinamômetro marca Instron (modelo 5569, Norwood, Estados Unidos)...... 102

Figura 3.14. Metodologia para desenvolver moldes em silicone .105

Figura 4.1. Processo de fiação. 109

Figura 4.2. Comparação entre fios. 110

Figura 4.3. Vista longitudinal do fio de algodão do presente estudo (aumento de 51 vezes)

Figura 4.4. Comparação entre a imagem obtida na literatura com a microscopia do corte transversal do fio de algodão encapsulado deste estudo.

Figura 4.5. Microscopias de fibras unicelulares

Figura 4.6. Linha de jeanswear da marca Loco utiliza algodão

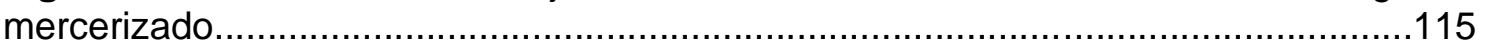

Figura 4.7. Estrutura química idealizada de um époxi simples (óxido de

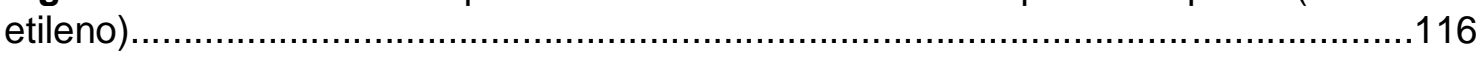

Figura 4.8. Estrutura da resina époxi bisfenol-A éter diglicil..................................117

Figura 4.9. Isômeros do ácido benzenodicarboxílico................................................119

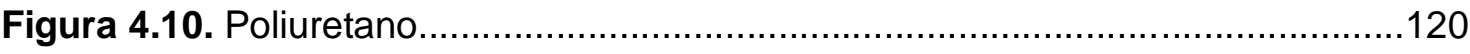

Figura 4.11. Metodologia desenvolvida para compósitos feitos de resina laminada de

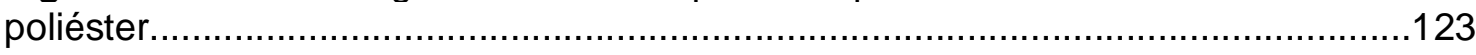

Figura 4.12. Metodologia desenvolvida para compósitos feitos com resina epóxi. .125

Figura 4.13. Metodologia de desenvolvimento de um compósito têxtil 126

Figura 4.14. Metodologia para testes de tração 128

Figura 4.15. Fotos dos compósitos produzidos com fibras de algodão de tecido denim. 131

Figura 4.16. Ampliações de 32 vezes dos compósitos no local de ruptura dos testes de dinamômetro comprovam a boa coesão entre a matriz polimérica e o reforço de resíduos têxteis. 134

Figura 4.17. Diferentes inspirações entre têxteis e resinas. .136 
Figura 4.18. Bijuterias feitas com compósitos têxteis - resina rígida ou flexível e reforço com fibras.

Figura 4.19. Alças e fechos de bolsas feitas com compósitos têxteis - resina rígida e reforço com fibras.

Figura 4.20. Saltos e ornamentos de sapatos feitos com compósitos têxteis - resina rígida e reforço com fibras.

Figura 4.21. Armações de óculos feitas com compósitos têxteis - resina rígida e reforço de fibras. 139

Figura 4.22. Materiais selecionados: resíduos têxteis de origem natural e sintética. 139

Figura 4.23. Bracelete produzido com resina epóxi e fibras têxteis oriundas dos resíduos da calça jeans e de uma camiseta. 141

Figura 4.24. Gema de colar produzido com resina epóxi e resíduos têxteis. 141

Figura 4.25. Gemas de anéis feitas de compósitos têxteis. 142

Figura 4.26. Brincos produzidos com resina epóxi e fibras de algodão... 142

Figura 8.1. Resina epóxi pura. 168

Figura 8.2. Resina epóxi reforçada com fibras de algodão 169

Figura 8.3. Resina de poliéster pura. 170

Figura 8.4. Resina de poliéster reforçada com fibras de algodão. 171

Figura 8.5. Resina de poliuretano 172

Figura 8.6. Resina de poliuretano reforçada com fibras de algodão. 173 


\section{LISTA DE EQUAÇÕES}

Equação 1. Determinação do Teor de Regain do Fio de Algodão..............................97

Equação 2. Determinação da Tenacidade......................................................103

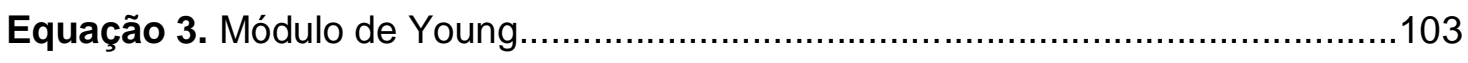

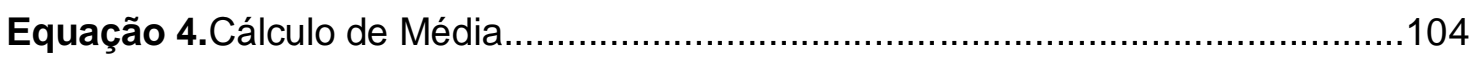

Equação 5.Cálculo de Desvio Padrão de Amostra...................................................104

Equação 6.Cálculo do Coeficiente de Variação.........................................................104 


\section{SUMÁRIO}

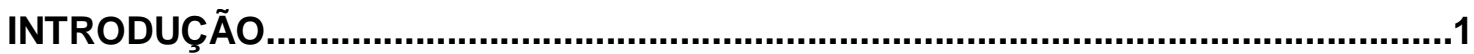

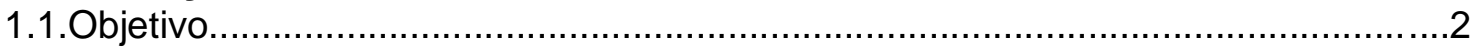

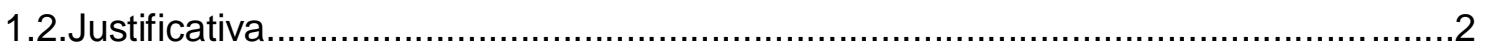

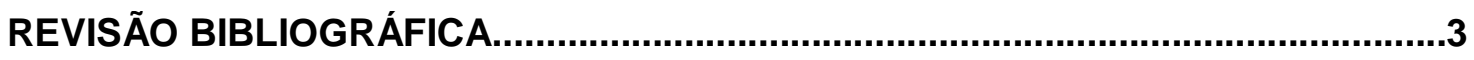

2.1. Cenário Econômico do Setor de Têxtil e Moda....................................................3

2.1.1. Dados Econômicos e o Grau de Competitividade do Setor................................

2.1.2. Cultivo, Mercado e Consumo da Fibra de Algodão......................................... 8

2.1.3. Moda: Entre Conceitos e o Consumo..........................................................12

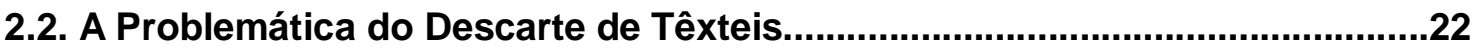

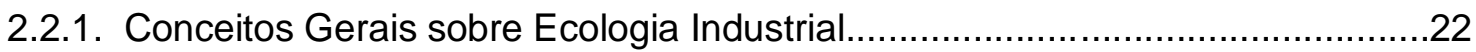

2.2.2. Ferramentas da Ecologia Industrial: Avaliação do Ciclo de Vida......................31

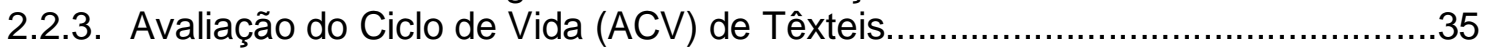

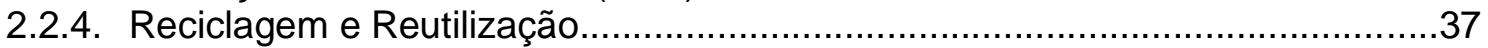

2.2.5. A Reciclagem de Resíduos Sólidos no Brasil e Uma Breve Comparação com o

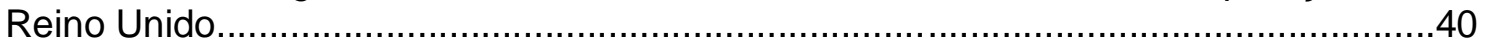

2.2.6. Os Resíduos na Cidade de São Paulo.........................................................46

2.2.7. O Bairro do Bom Retiro: Polo de Moda Popular de São Paulo e Gerador de

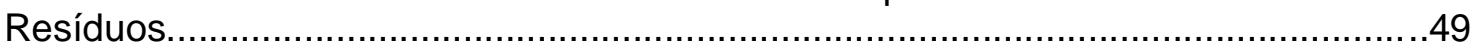

2.2.8. Reciclagem da Fibra de Algodão e Sua Posterior Fiação..................................51

2.2.9. Política Nacional de Resíduos Sólidos: um Avanço na Solução dos Problemas

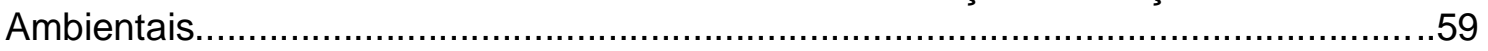

2.3. Materiais e Formas no Reuso e Reciclagem de Têxteis................................61

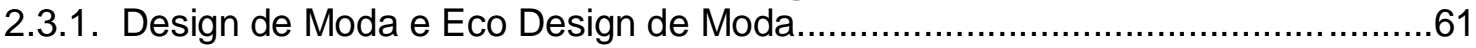

2.3.2. Introdução aos Materiais Compósitos............................................................72

2.3.3. Plástico Biodegradável como Matéria-prima na Produção de Compósitos

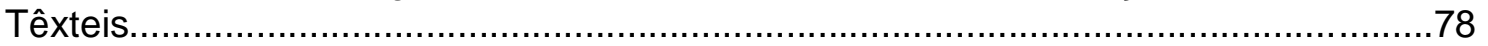

2.3.4. O Processo Criativo e a Seleção de Materiais e Processos................................80

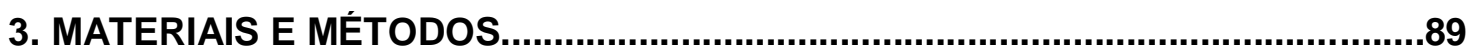

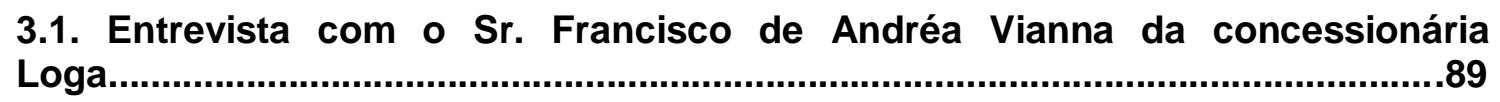

3.2. Obtenção dos Resíduos Têxteis........................................................................89

3.2.1. Obtenção dos retalhos de poliéster e algodão para os testes

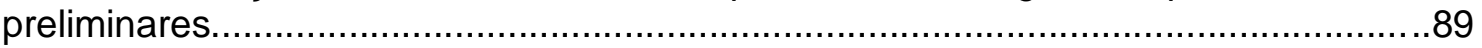

3.2.2. Obtenção dos Resíduos de Algodão para a Produção dos

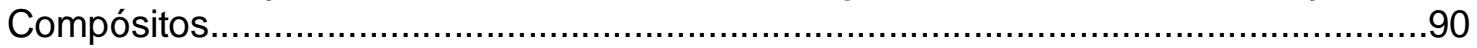

3.3. Análises Realizadas nas Fibras de Algodão.................................................91

3.3.1. Preparação dos Corpos-de-Prova e Análise Microscópica...............................91

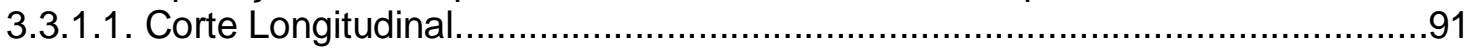

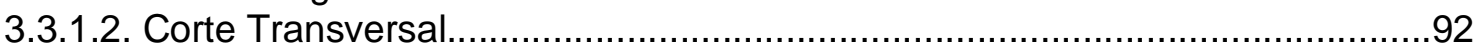

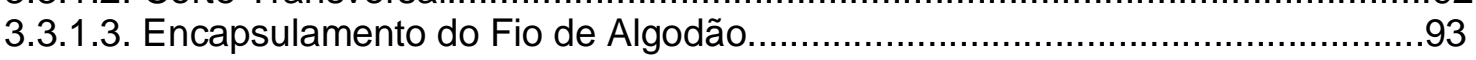

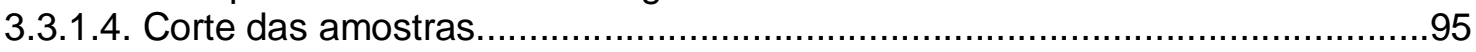

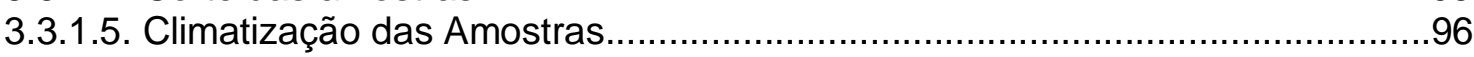




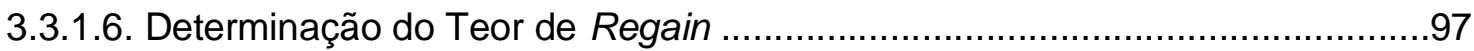

3.4. Produção e Ensaios dos Compósitos.................................................................97

3.4.1. Utilização de Resina Laminada (Poliéster Ortoftálico)...................................97

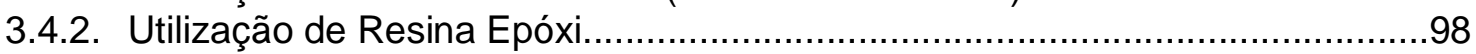

3.4.3. Utilização de Resina Epóxi e Retalhos de Poliéster........................................98

3.5. Produção dos Compósitos para Testes Finais.................................................99

3.5.1. Ensaio de Tração dos Compósitos............................................................102

3.5.2. Microscopia dos Compósitos (Local de Ruptura)..........................................103

3.5.3. Análise Estatística dos Resultados........................................................... 104

3.6. Sugestões de Aplicação Agregados ao Design dos Compósitos

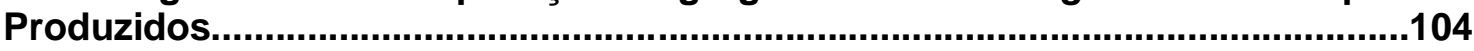

4. RESULTADOS E DISCUSSĀO........................................................................106

4.1. Entrevista com o Sr. Francisco de Andréa Vianna da Concessionária Loga................................................................................................................106

4.2. Análises dos Fios e Fibras de Algodão.......................................................108

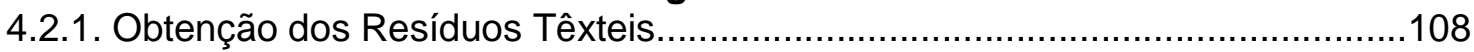

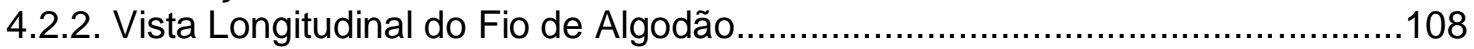

4.2.3. Vista Transversal do Fio de Algodão..............................................................111

4.2.4. Climatização e Determinação do Teor de Regain.........................................113

4.2.5. Das Resinas Utilizadas no Presente Estudo....................................................116

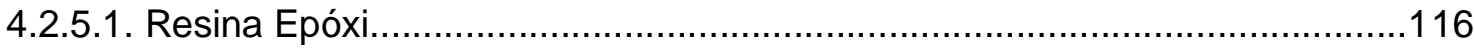

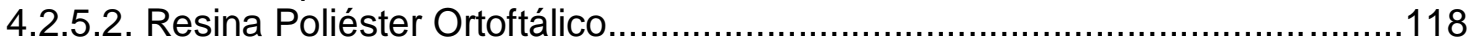

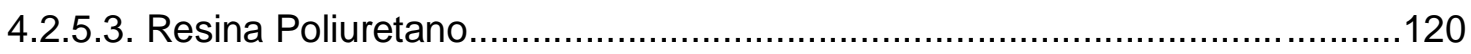

4.3. Produção de Compósitos Reforçados com Resíduos Têxteis.............................................................................................................121

4.3.1. Utilização de Resina Laminada (Poliéster Ortoftálico) ................................121

4.3.2. Utilização de Resina Epóxi.......................................................................... 124

4.3.3. Utilização de Resina Epóxi e Retalhos de Poliéster: Testes Preliminares no

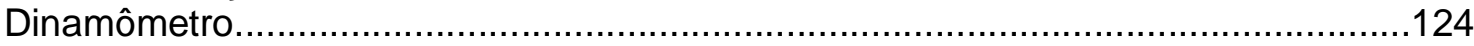

4.4. Ensaios Finais com Resinas Epóxi, de Poliéster Ortoftálico e de

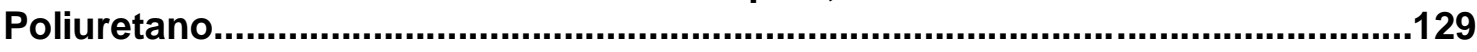

4.5. O Processo Criativo e as Sugestões de Aplicação dos Compósitos na área de Moda.

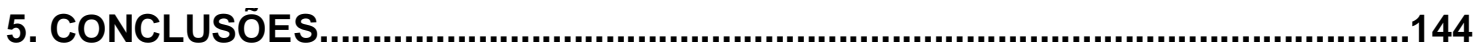

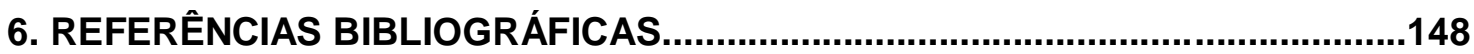

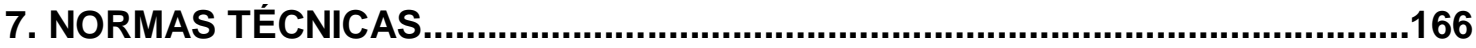

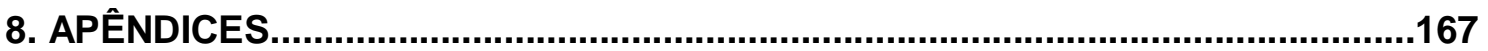

8.1. Roteiro de Entrevista Feita Com a Concessionária LOGA.............................167

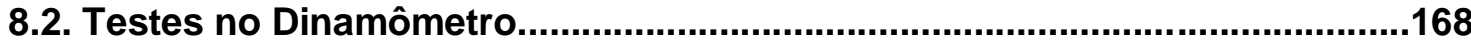

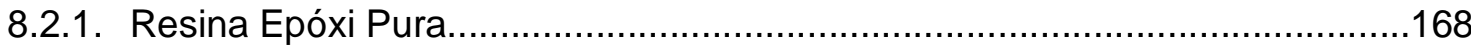


8.2.2. Resina Epóxi Reforçada com Fibras de Algodão...........................................169

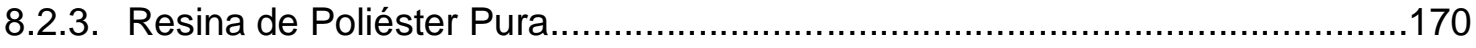

8.2.4. Resina de Poliéster Reforçada com Fibras de Algodão..................................171

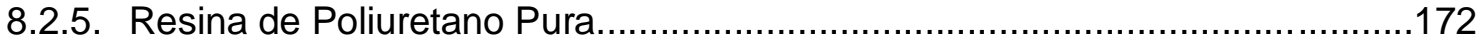

8.2.6. Resina de Poliuretano Reforçada com Fibras de Algodão.............................173

8.3. Legislação/Normas ABNT/CETESB - Resíduos Sólidos................................174 


\section{INTRODUÇÃO}

A presente pesquisa visou dimensionar a problemática do descarte indiscriminado de produtos têxteis e estudar possibilidades sustentáveis de reciclagem e de reuso da matéria constituinte desses artigos, principalmente os constituídos com fibra de algodão, notadamente a mais consumida no país e uma das mais consumidas mundialmente (ABIT, 2011). Desse modo, 0 presente estudo foi dividido em três grandes itens:

(i) Cenário Econômico do Setor de Têxtil e Moda - é relatado o panorama da atual situação do setor no Brasil em relação à competitividade, seus volumes de produção e suas perspectivas de evolução;

(ii) A Problemática do Descarte de Têxteis - à luz da Lei de Resíduos Sólidos (Lei 12.305 de 02/08/2010) e dos fundamentos de Ecologia Industrial e Avaliação de Ciclo de Vida (ACV), dimensionando-se a problemática do descarte indiscriminado de produtos têxteis no Brasil, com especial recorte na região do Bom Retiro (cidade de São Paulo - SP);

(iii) Materiais e Formas no Reuso e Reciclagem de Têxteis - são relatados aspectos relacionados com a produção de materiais compósitos (constituídos de matrizes termorrígidas e reforçados com fibras têxteis), ao design e ao eco-design aplicados na composição e aplicação desses compósitos na área de moda.

A parte experimental centrou-se primeiramente na caracterização dos fios de algodão e resinas utilizados, seguida da produção e caracterização dos compósitos através de ensaios de tração e alongamento, microscopia e regain. Em seguida, a partir da avaliação dos materiais produzidos, apontaram-se possibilidades de uso no campo da moda.

A associação das resinas cristalinas com fibras têxteis resultou em produtos finais de grande apelo visual, onde inúmeras combinações de cores podem ser produzidas, além de efeitos diversificados. Pelo tipo de efeito, os compósitos podem ser destinados à utilização na área de moda, compondo bijuterias, como pulseiras, anéis e brincos ou podem ser utilizados em outros setores do design de um modo geral. 


\subsection{OBJETIVO}

O estudo teve como principais objetivos realizar uma revisão bibliográfica sobre técnicas de reuso e reciclagem de têxteis, principalmente das fibras de algodão, bem como temas relacionados à ecologia industrial, ao design de moda e ao eco design. Na sua parte experimental também visou realizar ensaios de microscopia e de determinação de regain da fibra de algodão, bem como ensaios de tração, alongamento e microscopia em compósitos produzidos com três diferentes tipos de resinas termorrígidas (epóxi, poliéster ortoftálico e poliuretano) reforçadas com fibras têxteis de algodão, sugestão possível para a diminuição dos refugos têxteis em aterros sanitários. Para tais compósitos foram apontadas aplicações nos setores da moda.

\subsection{JUSTIFICATIVA}

Com base na revisão bibliográfica, bem como na entrevista realizada com o Sr. Francisco Vianna da concessionária LOGA (2011), responsável pela recolha do lixo em parte da cidade de São Paulo, certificou-se que há uma grande geração de resíduos têxteis: 16 toneladas por dia no bairro do Bom Retiro e 10 toneladas por dia no Brás, ambos os bairros grandes polos confeccionistas na capital paulistana, que são descartados em aterros sanitários. Soma-se também a isto o descarte indiscriminado de peças de vestuário por parte dos consumidores finais. Este material, em quantidade abundante, possui um amplo potencial reciclável e pode ser reutilizado como matéria-prima nos processos de fiação ou mesmo como reforço em compósitos de matriz termorrígida, suprindo parte da demanda do mercado por novos materiais e diminuindo a quantidade dos resíduos têxteis descartados. Os materiais compósitos produzidos a partir de resíduos têxteis poderiam trazer benefícios ao meio-ambiente, diminuindo a quantidade de resíduos, e - além de possuírem atribuições como resistência e coesão - poderiam ser destinados à área de moda ou outros setores do design pelos atributos visuais que proporcionam. Assim, são capazes de suprir necessidades específicas de consumo do mercado, ávido por novidades, bem como de suprir a demanda por estudos de novos materiais no setor de têxtil e moda. 


\section{REVISÃO BIBLIOGRÁFICA}

\subsection{Cenário Econômico do Setor de Têxtil e Moda}

\subsubsection{Dados Econômicos e o Grau de Competitividade do Setor}

No início da década de 1960, o Brasil era um país essencialmente agrícola. Metade dos trabalhadores estava empregada na agricultura, 15\% na indústria e apenas 35\% nos serviços. Entre os anos 1960 e 1980, a agricultura se modernizou, os trabalhadores deixaram o campo e vieram para as cidades trabalhar na indústria, representando cerca de $24 \%$ do total da mão de obra, e também no setor de serviços, representando cerca de $53 \%$ do total de empregos formais (VALOR ECONÔMICO, 2012).

Atualmente, o país é basicamente uma economia de serviços, que emprega $65 \%$ dos trabalhadores. Somente $16 \%$ deles estão na agricultura e a indústria, desde 1990, participa com apenas $1 / 5$ do total de empregos no Brasil (VALOR ECONÔMICO, 2012).

Até a década de 1970, o modelo vigente de produção industrial era o Fordismo, que estava alicerçado no tripé (BUARQUE, 2008):

(i) Abundância de recursos naturais e energéticos;

(ii) Aumento da produtividade do trabalho e

(iii) Presença do Estado Desenvolvimentista, ou seja, quando a política econômica é baseada no crescimento da produção industrial e da infraestrutura do país, com participação ativa do estado e estímulo maciço do consumo (MATTOS, 2006).

Contudo, com o passar dos anos e o começo da escassez de recursos naturais, bem como sucessivas crises internacionais por conta do aumento do preço dos barris de petróleo, entre outros, fez com que este modelo de produção deixasse de ser adotado (BUARQUE, 2008). A produção 
desenfreada em larga escala deu lugar à tecnologia de ponta e às pesquisas para melhorias de processos e de produtos; funcionários outrora mal remunerados deram lugar a profissionais altamente capacitados (BUARQUE, 2008); entre outros pontos a serem considerados, dá-se a esse conjunto de fatores o nome de competitividade sistêmica, que é o conjunto de condições proporcionado pela competitividade externa (país, estado ou região) às empresas, que influi diretamente na competitividade destas (FIESP, 2011).

As melhores empresas, no que tange recrutamento de Recursos Humanos $(\mathrm{RH})$, pesquisas em tecnologia e - muito recentemente - produção industrial sustentável, possuem um ganho considerável em competitividade e fatia de mercado, como vem ocorrendo no setor têxtil (FIESP, 2011).

Mais especificamente depois dos anos 2000, passou-se a falar em "serviços ambientais", ou seja, tratamento de água e do solo, preservação da flora e da mata, reciclagem de resíduos sólidos, etc., estimados em US\$40 trilhões de dólares pelo mundo, segundo ambientalistas e especialistas (BUARQUE, 2008).

Em pleno século XXI é muito difícil pensar em multinacionais ou até mesmo em empresas de grande porte e desvinculá-las da causa ambiental (como exemplos, há empresas do setor têxtil que tratam de seus efluentes, reciclam e reutilizam matérias-primas, otimizam sua produção, reduzem o gasto em energia, etc). Para uma empresa ser competitiva, atrativos como design diferenciado, tecnologia, inovação e produção sustentável devem ser levados em conta em sua produção de bens e/ou prestação de serviços (BUARQUE, 2008).

Além de ser um grande produtor de bens e de serviços em setores como o agrícola, o de mineração e o de petróleo, o Brasil é também um importante produtor mundial de artigos têxteis, ocupando a $7^{\text {a }}$ posição na produção de fios e tecidos planos e a $3^{\text {a }}$ na produção de tecidos de malha (FINKLER et al., 2005). Além disso, é o 5 maior produtor mundial de algodão, com o qual é feito $60 \%$ das peças de vestuários confeccionadas no país (ABIT, 2011). Segundo Fernando Pimentel, diretor superintendente da ABIT, estima-se que, em 2014, o comércio têxtil e de confecção no mundo alcance a cifra de US\$ 856 bilhões, participando o Brasil com $0,6 \%$ deste valor (ABIT, 2011). 
Dados de 2005 mostram que o setor da indústria têxtil no Brasil é o $4^{\circ}$ maior produtor têxtil mundial - ficando atrás apenas de países asiáticos como China, Índia e Indonésia (ECCOTÊXTIL, 2011), representando um total equivalente a $4,4 \%$ do PIB brasileiro e empregando cerca de $2 \%$ da população ativa, aproximadamente 1,7 milhões de trabalhadores diretos num levantamento feito em 2010 (CLOSET ON LINE, 2012). Existem também importantes eventos de moda, como a São Paulo Fashion Week, o maior da América Latina e um dos maiores do mundo, que investe aproximadamente 5 milhões de reais em cada edição, conta com a participação de aproximadamente 64 designers de moda e tem um público estimado em 1 milhão de pessoas (SP FASHION WEEK, 2012).

Deste modo, a indústria da moda, mais competitiva internacionalmente por desenvolver produtos com alto valor agregado (tecidos tecnológicos, design diferenciado e marketing maciço em produtos ecológicos, entre outros) em contraposição aos países asiáticos, por exemplo, que focaram sua produção em tecidos simples e de baixo custo, tem se mostrado eficiente e obstinada a desenvolver relações comerciais com outros países, além de possuir um mercado interno em potencial e com evidente expansão. Com um crescimento de mais de 5\% ao ano desde 2002 em sua produção (APEX - BRASIL, 2008), mobilizou em 2007 mais de $R \$ 2$ bilhões em exportações, segundo a ABIT Associação Brasileira de Indústria Têxtil e de Confecção, e teve um faturamento total de 60 bilhões de dólares em 2010.

Para que seja possível consubstanciar as questões de competitividade relativas à indústria nacional e as ações já realizadas, a ABIT (2012) realizou uma pesquisa intitulada "A Real Conjuntura da Indústria Têxtil e de Confecção Brasileira".

A despeito do processo de abertura comercial no início dos anos 1990, realizada de forma abrupta, a indústria têxtil e de confecções manteve seus planos de expansão e de investimentos. A modernização e o aumento de produtividade e competitividade tornaram-se reais em todos os segmentos da indústria têxtil e de confecção. É assim que foram direcionados mais de US\$ 1 bilhão/ano na aquisição de equipamentos modernos, de alta capacidade, para aumento da produtividade (ABIT, 2012). 
É importante sublinhar que, adicionalmente a esses recursos detalhados, foram investidos outros em treinamento, construção civil, máquinas e equipamentos modernos, capacitação e em pesquisa e desenvolvimento de produtos, processos e novas técnicas de gestão (ABIT, 2012).

Com relação à competitividade, a troca de máquinas e equipamentos é a parte mais dispendiosa do esforço para o aumento da produtividade $\mathrm{e}$ possibilita a obtenção de resultados significativos a curto prazo. Em relação à mão de obra qualificada, isso demanda maior tempo de maturação, item fundamental na melhoria e otimização dos processos de produção e que, muitas vezes, vai além do ambiente empresarial, envolvendo questões estruturais e culturais (ABIT, 2012). Segundo o Fórum Econômico Mundial, realizado anualmente em Davos, na Suíça, o Brasil foi o país que mais aumentou sua competitividade em 2009, ganhando oito posições, superando a Rússia pela primeira vez e fechando parcialmente a diferença de competitividade com a Índia e a China (SCHWAB, 2010).

Importantes passos dados desde a década de 1990 para a sustentabilidade fiscal, bem como as medidas tomadas para liberalizar e abrir a economia, impulsionaram significativamente os fundamentos do país em matéria de competitividade, proporcionando um melhor ambiente para 0 desenvolvimento do setor privado (SCHWAB, 2010).

Ainda assim, houve uma melhoria na infraestrutura de ensino e a enorme expansão da oferta de cursos técnicos e profissionalizantes de design, criação, moda, desenvolvimento de produtos, incorporação de nanotecnologia e biotecnologia dedicados ao setor, de nível médio e superior, fruto de uma demanda crescente nas empresas por profissionais qualificados e atualizados com as novas práticas de fabricação (ABIT, 2012).

A Tabela 2.1 apresenta resultados gerais de um recente benchmark internacional realizado pela Werner International (ABIT, 2006), uma consultoria norte americana de atuação global e especializada no segmento têxtil e confeccionista, que avaliou o grau de competitividade das indústrias têxteis brasileiras, identificando suas forças e fraquezas. É possível notar que o Brasil está, ainda que ligeiramente, à frente, em termos de eficiência industrial, da média dos países asiáticos - de baixos custos de produção, mas ainda atrás da Europa e dos Estados Unidos, justamente pela defasagem na produtividade da 
mão de obra e no grau de evolução dos sistemas de controle e gestão (ABIT, 2006).

Tabela 2.1. Benchmark global (processo comparativo entre dois ou mais sistemas) da instituição Werner International (ABIT, 2012)

\begin{tabular}{cccccc}
\hline Regiões & Fiação & Tecelagem & Malharia & Acabamento & Média \\
\hline Europa & 85 & 83 & 83 & 87 & 85 \\
América do Norte & 78 & 78 & 78 & 76 & 78 \\
Brasil & $\mathbf{7 2}$ & $\mathbf{6 8}$ & $\mathbf{8 3}$ & $\mathbf{7 8}$ & $\mathbf{7 5}$ \\
Ásia & 72 & 72 & 70 & 74 & 72 \\
\hline
\end{tabular}

Segundo um levantamento realizado pela International Textile Manufactures Federation - ITMF (2011), conclui-se que o Brasil é bastante competitivo - excetuando-se os custos de capital e os juros. Ele está à frente de países como Índia, China e Coréia do Sul no setor de fiação convencional ou na tecelagem que utiliza o fio Open End (um tipo de fio mais "rústico" que o convencional) como matéria-prima, como é o caso dos grandes fabricantes de denim para o segmento de jeanswear (ABIT, 2012).

É interessante ressaltar que, embora tais levantamentos no âmbito econômico possam justificar, inclusive, a eficiência de se reciclar as fibras de algodão e fiá-las novamente, não foram levantados questões relacionados ao nível de consciência ecológica dessas empresas do setor têxtil.

É sabido que uma escolha de fabricação que envolva tecnologias ambientais é parcialmente impulsionada pelo contexto organizacional da empresa e por sua receptividade em relação a novas ideias e à inovação. Uma fábrica tende a favorecer a adoção de tecnologias de prevenção à poluição (P2) e de sistemas de gestão ambiental (SGA) a partir de uma aprendizagem organizacional para operações sustentáveis. Os gestores, a fim de promover melhorias sustentáveis em suas empresas e criar valores a longo prazo, devem promover um clima social de troca de conhecimentos entre seus colaboradores e devem também criar também um SGA que não seja apenas um processo burocrático de documentação e cumprimento regulamentar ou um modo de 
angariar mais clientes ou satisfazer requisitos da matriz, mas sim um SGA que seja uma fonte de melhoria de processos e inovação (GAVRONSKI et al, 2012).

\subsubsection{Cultivo, Mercado e Consumo da Fibra de Algodão}

As fibras vegetais, também conhecidas como lignocelulósicas, apresentam vantagens em comparação às fibras sintéticas, por serem abundantes, renováveis, recicláveis, de baixo consumo energético na produção e neutras em relação à emissão de $\mathrm{CO}_{2}$, e estão se tornando alternativas atrativas do ponto de vista econômico e ambiental (GHAVAMI, 1988; COSTA; FUJIYAMA, 2011).

Segundo Finkielsztejn (2006), "o algodão atende a quase $45 \%$ do vestuário da humanidade, aproximadamente vinte e um milhões de toneladas, com cerca de 34 milhões de hectares plantados anualmente". Esta fibra é extraída das sementes do algodão (Gossypium sp.) e, por meio de grupos químicos da celulose de características polares similares as da água, o algodão é capaz de absorver umidade, propriedade muito importante no que diz respeito ao conforto e ao tingimento (BASRA; MALIK, 1984).

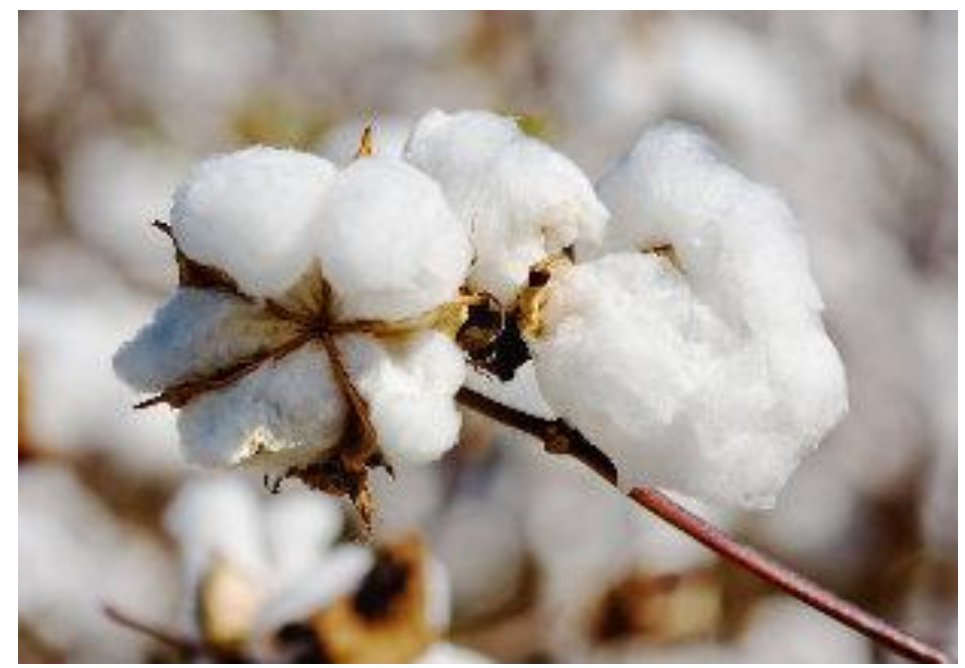

Figura 2.1. Capulho de algodão (REVISTA GLOBO RURAL, 2012)

Em relação à sua morfologia, o algodão é uma fibra unicelular, constituída de celulose, originada na parede das sementes do fruto (capulho) do algodoeiro. Em cada capulho, há cinco células. Em cada uma destas, 
crescem 2 a 6 grãos de sementes do tamanho de um grão de café. Nos grãos das sementes crescem os pelos que darão as fibras para a fiação. Cada caroço de algodão desenvolve entre 1.200 e 1.700 fibras (Figura 2.1) (BASRA; MALIK, 1984).

No Brasil, a cultura do algodão está entre as mais importantes do país, significando $70 \%$ das fibras naturais que são industrializadas. Em termos de produção e comércio, está longe de culturas como soja, mas ainda assim aparece como um dos produtos de grande relevância para a economia do país (IDEC, 2005).

Com uma maior concorrência a partir de 1990, com a abertura comercial, os confeccionistas optaram por comprar tecidos importados, especialmente da China, bem como manufaturados vindos de outras partes da Ásia, fazendo com que a produção brasileira de algodão caísse consideravelmente, havendo a necessidade de importar esta matéria-prima naquela época (IDEC, 2005).

$\mathrm{Na}$ última década, o país conseguiu recuperar parte de sua área plantada e começou a expandi-la, sobretudo, com o plantio na região do cerrado. A melhoria genética das plantas, o controle de pragas e insetos e a mecanização na lavoura, principalmente por parte dos grandes produtores, fez com que a produção fosse retomada e a importação de fibra diminuísse (EMPRAPA, 2011).

Contudo, mesmo importante para a economia do país, a cultura do algodão acarreta dois grandes problemas ambientais, a saber:

(i) o cultivo de algodão, por estar sujeito ao ataque de variadas pragas e doenças, necessita do uso frequente de agrotóxicos. O algodão é responsável por $24 \%$ do consumo de inseticidas e $11 \%$ do de pesticidas no mundo. O uso de tais substâncias, que pode chegar a $25 \%$ do custo total da produção, são as principais causadoras da poluição das águas do entorno dessas plantações, também podendo ocasionar 0 envenenamento do solo e dos lençóis freáticos (EMPRAPA, 2011); 
(ii) segundo a Empresa Brasileira de Pesquisa Agrícola EMBRAPA, ligada ao Ministério da Agricultura, o algodão transgênico algodão bt. (liberado no Brasil em 2005) contendo genes do Bacillus thuringiensis produz toxinas inseticidas e têm sido usadas em programas de manejo de pragas (EMBRAPA, 2011). Apesar de haver uma corrente de estudiosos que apoiam o plantio de algodão transgênico, afirmando que esta espécie é mais resistente a pragas e doenças e que, por isso, devem receber uma carga menor de agrotóxicos, garantindo uma boa produção e uma menor agressão ao meio ambiente, há outra corrente de estudiosos, principalmente ecologistas, que são contrários à utilização dessas sementes, e mostram por meio de pesquisas que os transgênicos podem afetar o equilíbrio do ecossistema. Além de colaborar diretamente para o processo de redução da biodiversidade e de extinção das espécies nativas cruzadas, a esterilidade torna os agricultores dependentes das empresas produtoras de sementes transgênicas (IDEC, 2005).

Na Tabela 2.2 a seguir são apontadas as principais características da fibra de algodão no que tange o meio ambiente, como biodegradabilidade, reciclagem, entre outros.

Tabela 2.2. Principais características da fibra de algodão no que tange o meio ambiente (ALYA, 2012)

É responsável por $24 \%$ do consumo de inseticidas e $11 \%$ do de pesticidas no mundo, Saúde embora utilize $2,4 \%$ da área total cultivada. Pode causar bicinose (disfunção pulmonar causada pela aspiração crônica de fibrilas de algodão). 


\begin{tabular}{cl}
\hline Ecossistema & (esse último causa a eutroficação das águas). \\
& Degradação da terra causada por salinização \\
& e erosão. \\
\hline Consumo de energia & Considerada toda a sua vida útil, os produtos \\
& de algodão apresentam no total maior \\
& consumo de energia que os sintéticos. Os \\
& maiores consumos estão focados no \\
& combustível para máquinas agrícolas e \\
& tratores, na fiação e, principalmente, nos \\
& processos de manutenção (lavagem, \\
& secagem e passagem a ferro). As principais \\
& razões são: necessidade de lavagem mais \\
& intensa, maior tempo de secagem em função \\
& da maior absorção de água, necessidade de \\
passagem a ferro, grandes perdas no & processo de produção, notadamente na \\
fiação (15 a $20 \%)$, menor vida útil do produto \\
final.
\end{tabular}

Água para irrigação de sete mil a 29 mil litros por quilo de fibra segundo o local de plantio.

Consumo de água $\quad$ No Brasil não se utiliza irrigação. Água usada nos processos de beneficiamento e acabamento.

\begin{tabular}{cl} 
Durabilidade (possibilidade de reuso) & \multicolumn{1}{c}{ Média durabilidade. } \\
\hline Biodegradabilidade & \multicolumn{1}{c}{ Biodegradável. } \\
\hline Reciclagem & $\begin{array}{l}\text { Pode ser reciclado, mas o pequeno } \\
\text { comprimento das fibras dificulta o processo. } \\
\text { Os resíduos da fiação são reaproveitados } \\
\text { para fios grossos e barbantes. }\end{array}$ \\
\hline
\end{tabular}

Segundo Fernando Pimentel, diretor superintendente da ABIT, o consumo de fibras de algodão cresceu no país: entre 1970 e 2010, esse consumo cresceu 248,8\% (ABIT, 2012). Já no mundo, no mesmo período, o crescimento foi de $108,3 \%$, acrescentando que o consumo brasileiro per capita também tem sinalizado aumento nos últimos tempos. O país saiu de $4,40 \mathrm{~kg}$ per capita em 1990 para 5,26 kg per capita em 2010. No mundo, o crescimento foi bem menor, subiu de 3,52 kg per capita para 3,65 kg per capita, no mesmo período. No Brasil, a participação do consumo de fibras de algodão em 2010 ficou em 57\% e, no mundo, o índice foi de 35,7\%. Em 1990, esse resultado era de $65 \%$ e $49 \%$, respectivamente (ABIT, 2012). 
Sendo o algodão a fibra mais consumida no país, também constitui, proporcionalmente, uma considerável porcentagem dos resíduos têxteis produzidos pelas indústrias de fiação e tecelagem, confecções e pelo descarte doméstico. Conclui-se que é uma matéria-prima abundante e que sua reciclagem ou reutilização deve ser considerada como alternativa para a diminuição do volume de lixo nos aterros sanitários.

\subsubsection{Moda: Entre Conceitos e o Consumo}

Desde a pré-história, diferentes grupos de indivíduos já utilizavam de artifícios têxteis para se protegerem das intempéries climáticas. Primeiramente, vieram as folhas vegetais e posteriormente as peles de animal. Contudo, usar tais vestimentas rudimentares não era apenas para proteção física (BRAGA, 2005).

Sob o ponto de vista de adorno, foi uma maneira que o ser humano encontrou de se impor aos demais, inclusive demonstrando bravura ao exibir dentes e garras de ferozes animais, além de ter a pele para cobrir o corpo com tangas ou sarongues e carne para a alimentação. Há ainda, o caráter de magia associados ao uso desses objetos, que dariam poder sobrenatural ao indivíduo que os possuíssem (BRAGA, 2005).

Com a fixação do ser humano ao solo, ele deixou de ser nômade caçador para se estabelecer com a criação de gado e a prática da agricultura. Isso também beneficiou a indumentária, visto que a lã e o linho (Figura 2.2) Ihe proporcionou, a princípio, a técnica de feltragem e, posteriormente, num processo evolutivo, a própria tecelagem (BRAGA, 2005). O linho é uma planta que chega a atingir um metro de altura e compõe-se basicamente de uma substância fibrosa, da qual se extraem as fibras longas para a fabricação de tecidos (ALFIERI, 2012). 

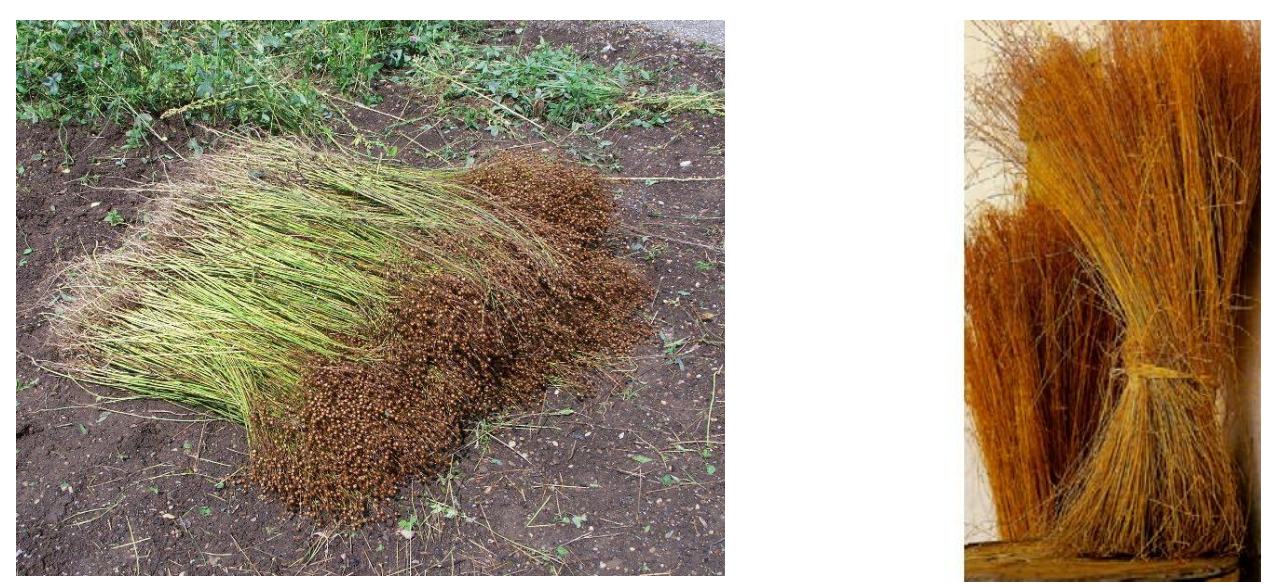

Figura 2.2. A planta linho logo depois de colhida e depois de seca, própria para a extração das fibras (CELSO LIMA ESTAMPARIA, 2012)

Com a manufatura de tecido, houve uma grande evolução na técnica e seu aprimoramento, tendo podido o homem produzir saiotes e outras peças e ornamentá-las com franjas, conchas, sementes, pedras coloridas, garras e dentes de animais (BRAGA, 2005).

A palavra moda significa costume e provém do latim modus ou "modo" e é utilizada para designar uma maneira de agir ou a repetição no modo de se vestir, por exemplo. Em inglês, moda é fashion - uma adequação da palavra francesa façon, que tem o mesmo significado (LAVER, 1995).

Para Lipovetsky (2004), a indumentária é um reflexo da civilização, representada pela riqueza de detalhes presentes em cada período da história da civilização. $O$ conceito de moda originou-se na Idade Média, por volta de XIV e XV, na Europa Ocidental. As grandes mudanças socioculturais e econômicas que se verificaram naquela época, como a aceleração das trocas comerciais, inclusive com o Oriente, a prosperidade das cortes do norte da Itália, berço do nascimento, e a emergência da noção de indivíduo vão permitir que a "fantasia estética" (LIPOVETSKY, 1989) realize-se através de mudanças cada vez mais aleatórias e frequentes no vestuário (CALDAS, 1999).

A partir desse período surgiu também na burguesia o desejo de imitar a aristocracia, ou seja, imitar os usos, hábitos e costumes de uma classe social acima da sua como forma de se inserirem neste outro patamar. Os camponeses, contudo, alheios à moda e aos modismos, continuaram a se vestir mais ou menos da mesma forma até meados do século XIX, período em 
que o conceito sobre moda passará a ser bem próximo ao que se tem atualmente, mudando ciclicamente em espaços mais curtos de tempo (BRAGA, 2005).

Cada vez que a burguesia se apropriava, por assim dizer, de algum costume ou mesmo do vestuário de classes acima da sua - a aristocracia, o grupo dominante mudava rapidamente seus hábitos, a fim de diferenciar-se. Criavam-se também regras de etiqueta e normas sociais que os nobres conseguiam assimilar facilmente a despeito dos burgueses, para que se preservasse a ordem social no dado momento.

Atualmente, o vestuário seria um signo portador de mensagens que nos falam do indivíduo que a veste e da sociedade que a produziu (CALDAS, 1999). Se fosse possível, ainda, sintetizar moda em uma única ideia, a palavrachave seria "mudança", ou seja, a troca ou substituição do velho pelo novo, do ultrapassado pelo moderno, sempre em movimentos cíclicos - uma vez que a moda tal qual se conhece (re)utiliza referências passadas para compor os lançamentos atuais (Figuras 2.3 e 2.4).

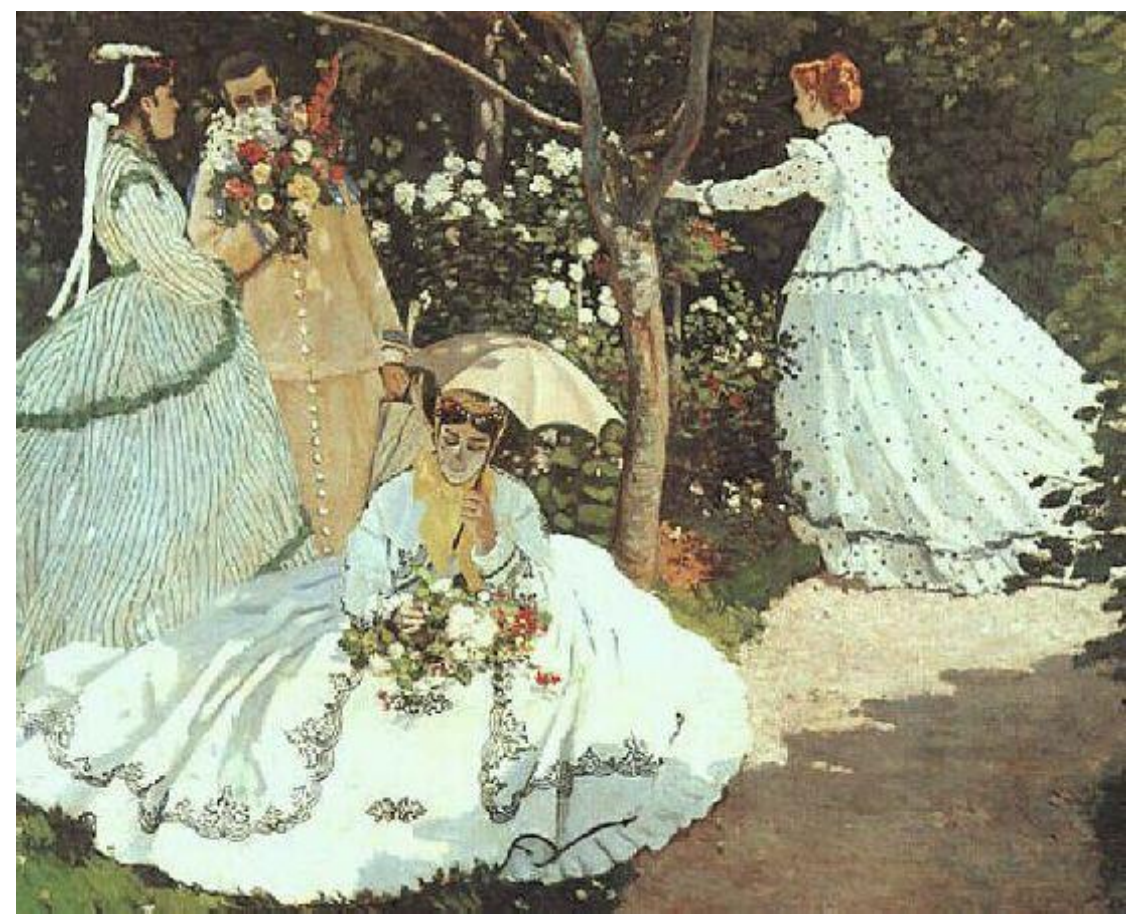

Figura 2.3. Quadro a óleo do pintor francês Claude Monet intitulado "Femmes au jardin" (1866), que retratou o vestuário das mulheres do séc. XIX, período em que o conceito de moda, tal qual como é conhecida hoje, começou a nascer (ART, 2012) 
A moda também se alicerça na capacidade de estimular o consumo, de satisfazer e criar novas necessidades, de suprir a vontade de diferenciação dos indivíduos ou mesmo a vontade de se inserir em determinados grupos sociais.

Dentro da definição de moda, cabem outras definições e conceitos. Sabe-se que, por exemplo, a moda é usada de dois principais modos, muito estudado pelo sociólogo alemão Georg Simmel (1989):

i) Suprir a necessidade de diferenciação dos indivíduos;

ii) Ao mesmo tempo em que determinados grupos se distanciam de outros (por meio de estilos diferentes de se vestir, por exemplo), há pessoas que se aproximam justamente pela afinidade de seu estilo de vida e de vestuário; ou seja, supre também a necessidade de pertencer a algum grupo. Para Simmel (1989), a moda é a mudança obrigatória do gosto.

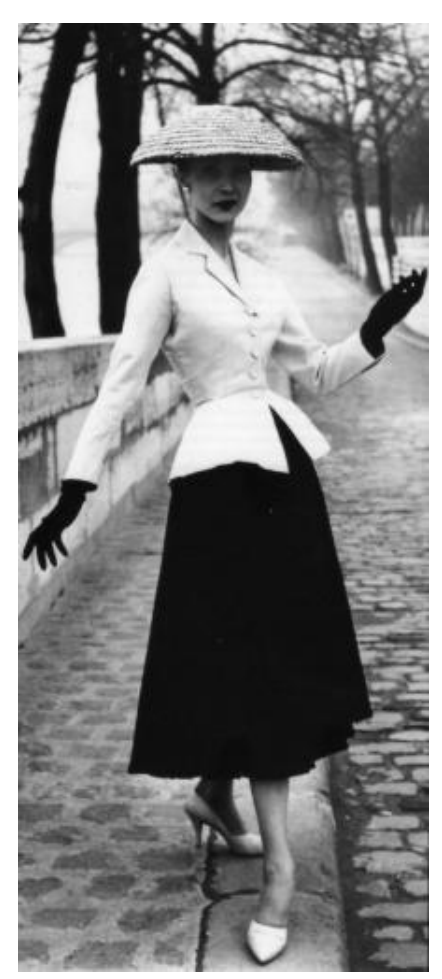

(a)

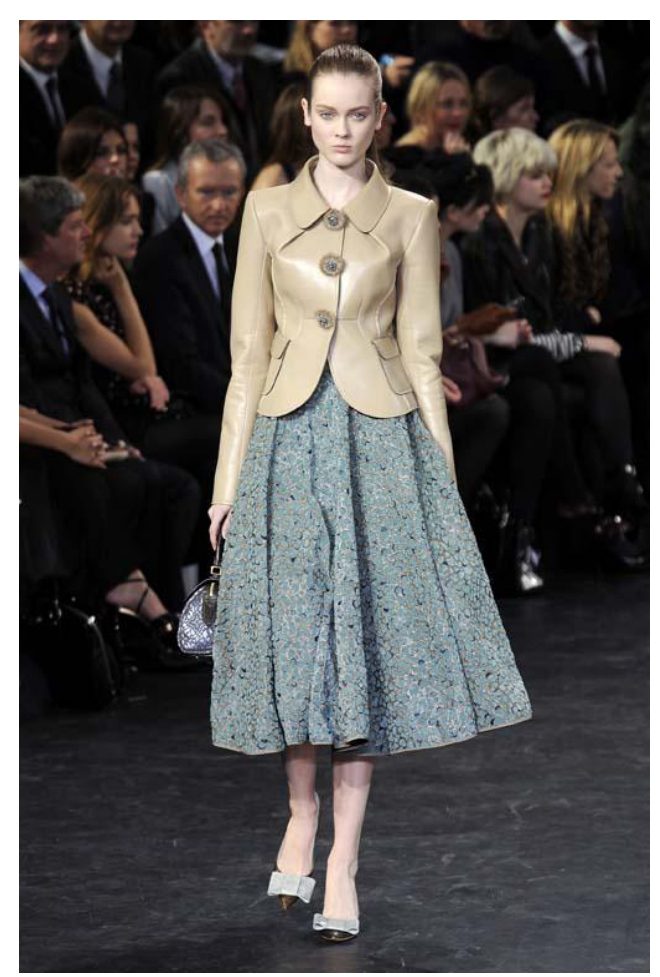

(b)

Figura 2.4. Exemplo de utilização de referências passadas na moda: (a) $O$ New Look criado por Christian Dior em 1947 era um resgate à feminilidade perdida após a II Guerra Mundial (BRAGA, 2005); (b) Desfile de inverno 2010 da marca Louis Vuitton, que se inspirou claramente em Dior (STYLE, 2012) 
Para Waizbort (2008):

[...] o fenômeno da imitação desempenha um papel de destaque. Ela opera uma espécie de "passagem da vida do grupo na vida individual", facultando ao indivíduo assimilar-se em meio ao grupo, como parte dele, como um "recipiente de conteúdos sociais". O princípio de imitação representa assim um lado do dualismo, cuja outra face é dada pela diferenciação individual, pela negação do imitar - o inventar. A imitação é "uma das direções básicas de nossa essência" e possibilita a "fusão do singular na universalidade", ou seja, "enfatiza em meio à mudança aquilo que permanece". Mas se fizermos o contrário e, em meio ao que permanece, enfatizamos a mudança, o que aflora são as tendências individualizantes, que procuram a diferenciação do indivíduo ante o grupo, a emersão do singular em meio à universalidade.

Atualmente, a moda congrega algumas características que influenciam diretamente na vida das pessoas. Segundo Caldas (1999), haveria:

(i) a necessidade de um guarda-roupa diversificado, que corresponda às necessidades dos indivíduos nas diversas ocasiões;

(ii) o mix de estilos, havendo o fim do "total look", ou seja, o fim de um estilo único no modo de se vestir;

(iii) maior variedade e menos variabilidade, ou seja, o individuo estaria assíduo por consumir diferentes peças de roupas com um estilo que durasse mais que uma estação;

(iv) a busca pelo conforto e não só pela beleza da peça, encontrado por exemplo, em tecidos tecnológicos;

(v) o poder do indivíduo em pulverizar os estilos e relativizar a ditadura da moda, ou seja, o poder de cada um de usar roupas que se sinta bem e até de criar um estilo pessoal ou mais autoral. Para Ted Polhemus (1997), pioneiro no estudo da "moda de rua" - a moda que 
nasce nos grandes centros urbanos, os indivíduos seriam "estrategistas do estilo" ou estilistas de si próprios ao invés de serem totalmente dominadas pela moda. Polhemus (1994) classifica tal efeito como "bubble up" (ebulição), quando a moda surge das ruas e vai para as passarelas, havendo também o efeito contrário denominado "trickle down" (gotejamento).

Em relação ao consumo, segundo uma pesquisa realizada pela $A B I T$ (2012), os 3 principais fatores psicológicos que influenciam no momento da compra de moda se baseiam no desejo de diferenciação, de mostrar status e na vontade de pertencer a um grupo (Tabela 2.3)

Tabela 2.3. Influenciadores e motivações no momento da compra (ABIT, 2012)

\begin{tabular}{c}
\hline 1- Destacar-se, diferenciar-se \\
$\mathbf{2}$ - Mostrar status, poder \\
$\mathbf{3}$ - Pertencer a um grupo \\
\hline 4 - Autoindulgência \\
5 - Preencher vazios existenciais \\
6 - Sentir-se em dia com a modernidade \\
7 - Impor respeito \\
\hline
\end{tabular}

Por meio de propagandas sedutoras em praticamente todos os meios de comunicação como jornais, revistas, Internet e principalmente televisão apontada como o grande meio de difusão de moda por $72 \%$ dos entrevistados, a moda consegue suprir necessidades estéticas dos indivíduos como gerar novas necessidades e desejos. Dos entrevistados, $47,5 \%$ já compraram produtos de moda por causa de propagandas, sendo maior o índice entre as mulheres, com 52,7\% (CLOSET ON LINE, 2012).

As lojas de rua são, ainda, o local preferido para compra de $56,2 \%$ das pessoas, sendo que quanto mais jovem o consumidor, maior a preferência pelas compras em shoppings (CLOSET ON LINE, 2012).

Os consumidores são atraídos para este mundo - até lúdico - de consumo, ostentação, desejos e satisfação pessoal. As grandes marcas 
europeias e americanas se utilizam das vitrines, por exemplo, para exercer esta "sedução" do cliente a atraí-lo para dentro da loja, onde se depara com uma gama de produtos estrategicamente posicionados em araras e prateleiras, enfatizados por uma iluminação também perfeita (DEMETRESCO, 2001).

A luminosidade foca o produto a ser direcionado para ele e obscurece os cantos, delineando contornos, criando sombras, aumentando ou diminuindo a penumbra; dá maior ou menor força às cores, modificando a textura dos elementos; unifica e pontua os elementos inseridos no discurso com o propósito de atrair um espectador tanto pela razão quanto pela sensação (DEMETRESCO, 2001).

Finkielsztejn (2006) constata que:

[...] por isso, a produção de roupas deixou de ser apenas uma necessidade e transformou-se também em artigo de desejo. A moda se insere neste contexto como uma forma da expressão do tempo e momento vivido pelas sociedades, sofrendo constantes atualizações e, assim, demandando mais matéria-prima, energia e esforços sociais, ambientais e industriais para a produção de artigos têxteis. $\mathrm{O}$ consumo de objetos é o próprio sentido da sociedade industrial calcada da produção em escala de bens de produção e na manutenção da produtividade.

É também nos diferenciais simbólicos inseridos no objeto que a competitividade hoje se fundamenta. Através do consumo, busca-se a satisfação de desejos não saciados, partindo-se de um objeto a outro. Soma-se a isso uma estratégia do industrialismo, a obsolescência planejada (QUEIRÓZ, 2003), em que a vida útil de um produto possui um prazo pré-estabelecido: 0 objeto é reposto em determinado espaço de tempo, resultando em novo consumo, que substitui o artefato anterior, então considerado obsoleto, ainda que haja condições técnicas para que o produto "sobreviva" por mais tempo (FINKIELSZTEJN, 2006).

É importante enfatizar que na moda ocorrem muitas mudanças, havendo a efemeridade como qualidade principal, além dela ser um potencial catalisador de estímulo à produção crescente de artigos têxteis, atingindo o meio ambiente 
de diversas formas, como: esgotamento de recursos naturais (por exemplo, pelo uso do solo para cultivo do algodão até sua exaustão ou ainda a degradação dos rios por despejos de efluentes de tingimento). Sem contar a inexistência de um projeto de descarte de têxteis, em nível público ou privado, que trate especificamente do descarte do referido material no Brasil, ou seja, não há um caminho traçado para o fim ao artigo têxtil velho ou deteriorado, apesar de recentemente ter sido aprovada a Política Nacional de Resíduos Sólidos (Lei 12.305 de 02/08/2010) (BRASIL, 2011; Relação de Normas ABNT/CETESB - Apêndice 8.3).

Como exemplo, pode se citar a rede espanhola Zara, um grande magazine do setor de Fast Fashion, que possui mais de 34 lojas espalhadas pelo Brasil. A ideia do Fast Fashion ou "moda rápida" é a de reproduzir o estilo das peças de roupas vistas nas passarelas dos grandes eventos de moda e transportá-las para as prateleiras de maneira extremamente veloz (CIETTA, 2010). A Zara, por meio de sua logística, consegue trazer para suas lojas um sortimento de produtos bastante variado e que foram vistos nas principais semanas de moda em menos de um mês (Figura 2.5).

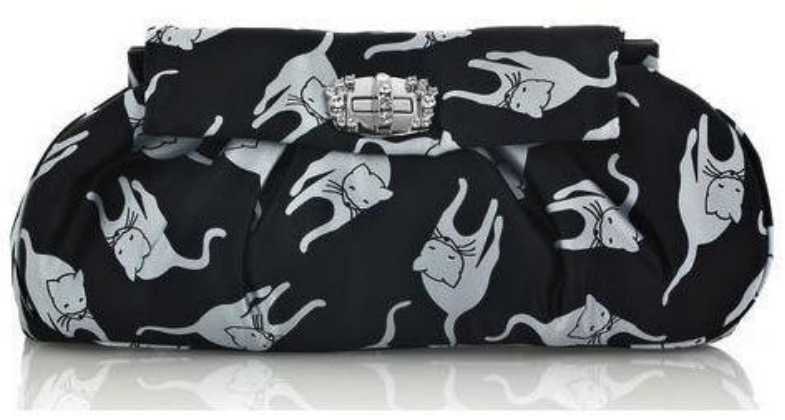

(a)

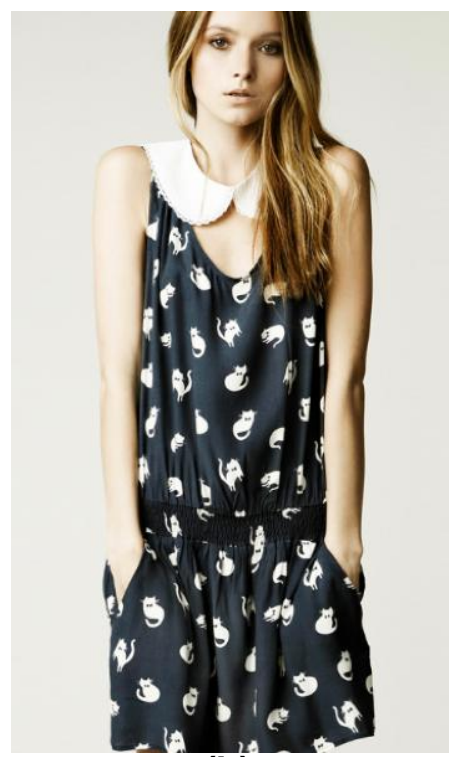

(b)

Figura 2.5. Exemplo da rápida absorção de tendências pelo magazine Zara: (a) bolsa com estampa de "gatinhos" da grife italiana Miu Miu, mostrada no desfile Primavera-Verão 2011 (MIU MIU, 2012); (b) vestido do magazine Zara com estampa de "gatinhos" muito parecida com a da grife Miu Miu (ZARA, 2012) 
Em todo o mundo, muitas companhias focadas neste nicho de mercado contam com "caçadores de tendências", profissionais que estão sempre em alerta nos principais acontecimentos mundiais, inclusive no que celebridades, anônimos e profissionais da moda vestem. Com isso, magazines como a Zara investem em minicoleções que podem atendem as solicitações pontuais do mercado o mais rápido possível. Isto indica que há um imenso dinamismo na produção que também se reflete no consumo, tendo girado 52 bilhões de dólares em todo o setor têxtil e de confecção no país no ano de 2010 (ABIT, 2012).

O economista italiano Enrico Cietta (2010) afirma que, apesar deste estilo de negócio ser recente no país, ele vem crescendo e se aprimorando bastante. O Fast Fashion não seria, como se pensa comumente, um modo de produção de baixa qualidade e com pouco valor agregado, mas sim um modo de produção criativo e de ciclo contínuo, impulsionado pela alta rotatividade e uma eficiente gerência da cadeia de criatividade.

Contudo, apesar do mercado poder absorver uma demanda grande de peças de roupas, há a necessidade de pensar como se dão esses meios de produção, de consumo, de manutenção e de descarte das mesmas, considerando que a vida média de uma peça de vestuário, cerca de três anos, é muitas vezes diminuída para uma única estação (TEXTILE ON LINE, 2011).

De acordo com uma abordagem preliminar, no período de fevereiro a setembro de 2009, 92,7\% dos resíduos têxteis advindos de fontes domésticas foram enviados para aterros sanitários e apenas 7,3\% foram doados para servir como matéria-prima para produtos desenvolvidos por programas sociais (MILAN; VITORAZZI; REIS, 2010).

Ou seja, há uma potencialidade destas peças descartadas serem reaproveitadas e recicladas, já que o capital natural é escasso (SCHWARZ, 2009), diminuindo o impacto ambiental e demandando também um menor empenho social e industrial para a produção de artigos têxteis, mas suprindo a demanda econômica. Segundo Katie Sturch (2012), analista de varejo e de tendências em merchandising para o site WGSN, famoso no segmento de pesquisas em macro e microtendências de moda e comportamento: "no varejo, temos visto marcas focadas na ideia do reuso e da reciclagem, marcas que 
oferecem qualidade e um produto que sobrevive mais que o tempo do fast fashion".

Para Finkielsztejn (2006):

\begin{abstract}
O aproveitamento de resíduos mostra-se como uma alternativa para aliviar a sobrecarga nos aterros sanitários e, simultaneamente, motiva pesquisas de tecnologias para o desenvolvimento de produtos sustentáveis de Arquitetura \& Design.
\end{abstract}

Ainda, segundo pesquisa da ABIT (2012), os consumidores brasileiros não se preocupam com o modo como suas roupas são fabricadas. O mais importante para eles é ter acesso aos bens de consumo, ignorando a origem, o processo de fabricação e o pagamento de tributos, visto que apenas $27,1 \%$ dos entrevistados costumam olhar as etiquetas das peças de vestuário/artigos de moda para saber a origem do produto (CLOSET ON LINE, 2012).

Os mesmos consumidores também alegam que os produtos ecologicamente corretos possuem preço superior aos demais e, para eles, produtos importados são aqueles produzidos nos Estados Unidos e na Europa, desconsiderando o fato de que os produtos asiáticos também se enquadram nessa classificação. Para os consumidores, os produtos produzidos nos EUA ou Europa são melhores em todos os sentidos: mais baratos, possuem maior variedade de tamanhos, modelos, estilos e cores, além de ser mais duráveis e possuírem maior qualidade como um todo. A pesquisa ainda revelou que 0 quesito sustentabilidade ficou em último grau de relevância no momento da compra (ABIT, 2012).

Em contrapartida, o segmento ligado à moda ecológica movimenta entre $\mathrm{R} \$ 270$ e $\mathrm{R} \$ 362$ milhões por ano no Brasil. Uma peça produzida com tecido orgânico pode custar até $30 \%$ a mais do que outras peças não ecológicas (Figura 2.6). Uma blusa de tecido orgânico, por exemplo, chega a valer o triplo de uma blusa de algodão, poliéster ou poliamida, que não passou por processos rigorosos de controle ambiental. Isso se dá ao fato de que essas peças são feitas com a isenção de trabalho escravo ou mal remunerado e, 
geralmente, são produzidas em baixa escala pela pouca demanda do mercado (MODA ECOLÓGICA, 2012).

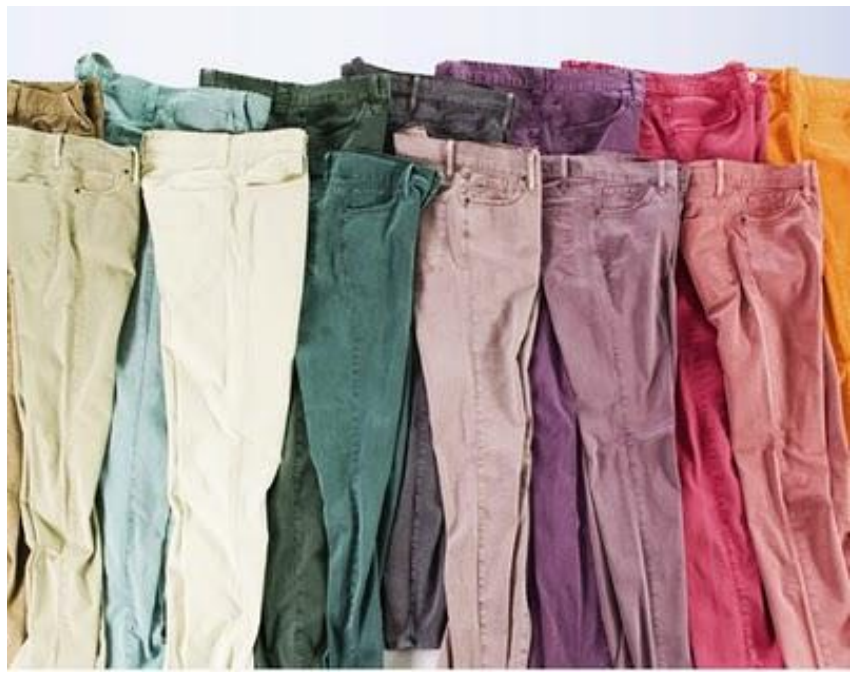

(a)

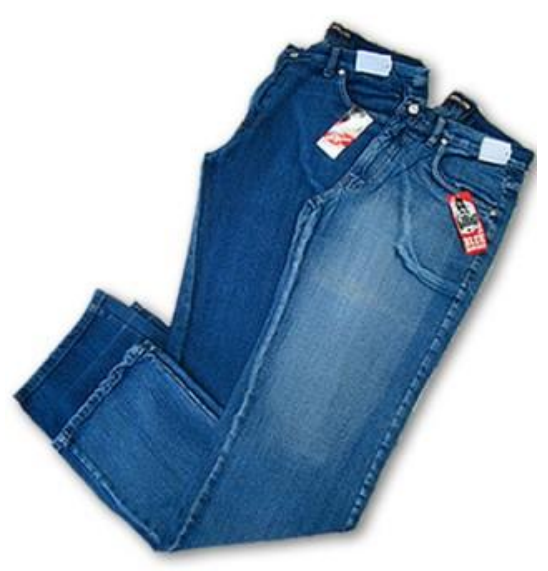

(b)

Figura 2.6. Diferenças de preços entre calças jeans ecológicas e as convencionais: (a) as calças jeans ecologicamente corretas da marca Éden podem custar $R \$ 229,00$ segundo o portal GNT (Programa Tamanho único) (BRASÍLIA CAPITAL BLOG, 2012), enquanto que (b) as calças jeans importadas da Ásia podem custar $\mathrm{R} \$ 28,00$, segundo o portal do magazine Lojão do Brás (LOJÃO DO BRÁS, 2012)

\subsection{A Problemática do Descarte de Têxteis}

\subsubsection{Conceitos Gerais sobre Ecologia Industrial}

Até meados dos anos 1950, concebia-se o sistema produtivo separado do meio ambiente, portanto, os problemas ambientais situavam-se fora das fronteiras do sistema industrial (ARAÚJO et al, 2012). Ou seja, os estudos focalizavam-se nas consequências da poluição no meio ambiente e não nas causas. Tal modo de encarar os problemas ambientais é chamado, atualmente, de End-of-Pipe Treatment ou Tratamento de Fim de Tubo, o qual visa tratar os resíduos gerados pela indústria sem haver, de fato, uma preocupação em otimizar os processos industriais como um todo (redução do consumo de 
energia, do consumo de água, entre outros, por exemplo) e minimizar o resultado final do impacto (Figura 2.7).

A aplicação generalizada dos tratamentos de Final de Tubo vem sendo reanalisadas pelas empresas por se tratar de um processo oneroso e que, muitas vezes, não minimiza os impactos ambientais, apenas transfere 0 impacto de um meio para o outro, da água para o solo por exemplo.

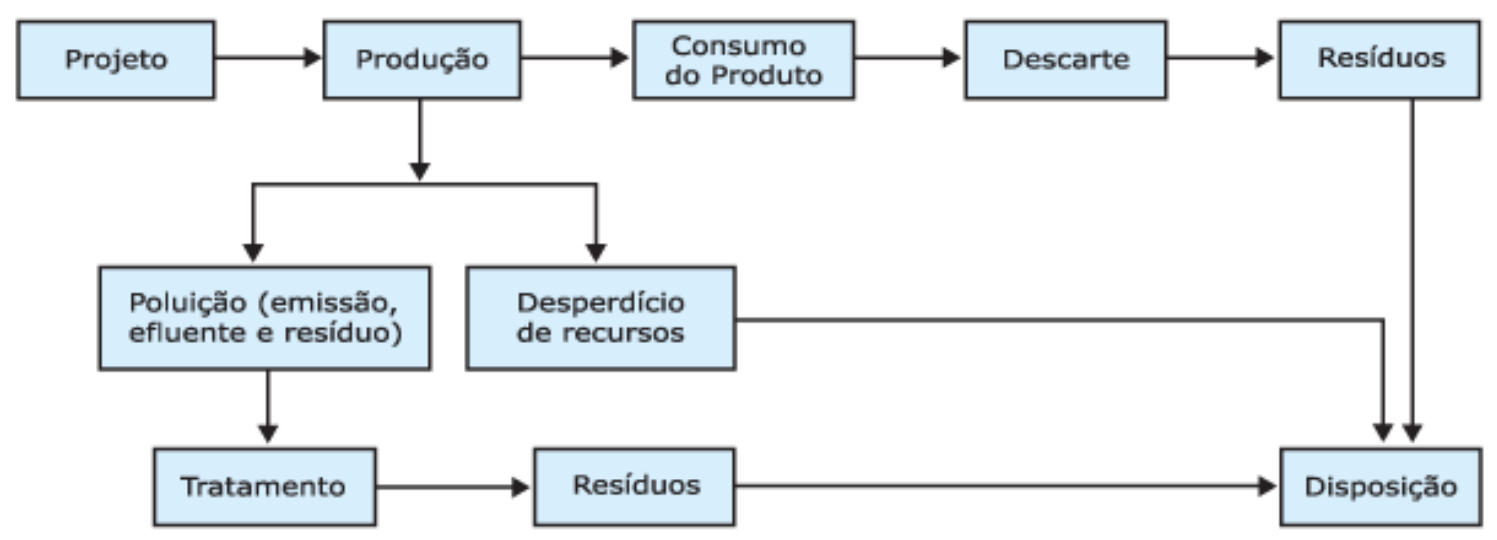

Figura 2.7. Controle Final de Tubo (ARAÚJO et al, 2012)

Após o reconhecimento da ecologia industrial como um campo de pesquisa, bem como do crescente estudo em relação ao desenvolvimento sustentável, o Tratamento de Final de Tubo passou a ser substituído sistematicamente pelas empresas por outros métodos mais eficientes e com maior controle (ALMEIDA; GIANNETTI, 2009).

A expressão "desenvolvimento sustentável", segundo Barbieri (2002), surgiu pela primeira vez em 1980 no documento denominado World Conservation Strategy produzido pela UICN - International Union for Conservation of Nature e pela World Wildlife Fund (hoje renomeada como World Wide Fund for Nature - WWF) por solicitação da PNUMA - Programa das Nações Unidas para o Meio Ambiente. O objetivo da conservação, segundo esse documento, é o de manter a capacidade do planeta para sustentar o desenvolvimento, e este deve, por sua vez, levar em consideração a capacidade dos ecossistemas e as necessidades das futuras gerações (BARBIERI, 2002; LUMI, 2009), posto que a origem dos problemas ambientais globais, tais como as mudanças climáticas, a diminuição da camada de ozônio, a perda de biodiversidade e habitat ou a escassez e a poluição da água, 
podem ser atribuídas à desmedida expansão mundial do sistema industrial (ERKMAN et al, 2005).

Deste modo, a ecologia industrial se relaciona com o desenvolvimento sustentável, uma vez que a primeira aborda a relação entre indústria e o meio ambiente, visando criar uma eco rede que imite os ciclos biológicos e que leve em conta os limites da capacidade de carga do planeta, entre outros aspectos favoráveis ao meio ambiente. Assim, a ecologia industrial vem sendo desenvolvida nos países industrializados, principalmente nos Estados Unidos, na comunidade Europeia e no Japão. Ela tem sido tema de vários livros e periódicos, os quais vêm surgindo desde os anos 1990, como o Journal of Industrial Ecology, dedicado exclusivamente à Ecologia Industrial, e o Journal of Cleaner Production, inicialmente direcionado a promover a Produção Mais Limpa (P+L) (ARAÚJO et al, 2012).

A partir dos anos 1990, o conceito de ecologia industrial passou a receber considerável atenção tanto do setor acadêmico quanto do econômico e social. Em relação à sua definição, não há um consenso, porém, há vários pontos em comum entre as diversas definições encontradas na literatura (ARAÚJO et al, 2012):

(i) A ecologia industrial é sistêmica, abrangente, possui uma visão integrada de todos os componentes do sistema industrial e seus relacionamentos com a biosfera;

(ii) Enfatiza o substrato biofísico das atividades humanas e os complexos padrões do fluxo de material dentro e fora do sistema industrial, em contraste com a abordagem atual que considera a economia em termos de unidades monetárias abstratas;

(iii) Considera a formação de parques industriais (eco redes) como um aspecto chave para viabilizar o ecossistema industrial;

(iv) Leva em conta os limites da capacidade de carga do planeta e da região; 
(v) Induz o projeto e a operação a modelar-se como as atividades dos sistemas biológicos, otimizando ciclo de materiais de forma a aproximar-se de um ciclo fechado, utilizando fontes de energia renováveis e conservando materiais não renováveis.

Contudo, antes dos anos 1990, alguns autores já utilizavam as metodologias referentes à ecologia industrial para o estudo e análise de sistemas para simular a degradação ambiental do planeta, como os professores Jay W. Forrester e Donella Meadows, então pesquisadores do MIT - Massachusetts Institute of Technology, situado nos EUA, nas décadas de 1960 e 1970. É também possível encontrar conceitos inerentes à Ecologia Industrial nas obras de diversos autores, como os ecologistas Howard T. Odum e Charles Hall.

Na Tabela 2.4 é possível verificar quais são os principais autores sobre o assunto e o título de suas principais obras referentes à Ecologia Industrial:

Tabela 2.4. Evolução histórica no estudo da Ecologia Industrial e seus principais autores (ARAÚJO et al, 2012)

\begin{tabular}{ccc}
\hline & Ano & Publicações \\
\hline $\begin{array}{c}\text { Eugene P. } \\
\text { Odum }\end{array}$ & $\mathbf{1 9 7 1}$ & $\begin{array}{c}\text { Fundamentals of Ecology: uma das referências } \\
\text { básicas da ecologia. }\end{array}$ \\
\hline $\begin{array}{c}\text { Howard T. } \\
\text { Odum }\end{array}$ & $\mathbf{1 9 7 1}$ & $\begin{array}{c}\text { Environment Power and Society: integração de } \\
\text { sistemas a partir de fluxos de energia, a interação } \\
\text { entre sistemas industriais e ecológicos. }\end{array}$ \\
\hline $\begin{array}{c}\text { Nicholas } \\
\text { Georgescu- } \\
\text { Roegen }\end{array}$ & $\mathbf{1 9 7 1}$ & $\begin{array}{c}\text { The Entropy Law and the Economic Process: } \\
\text { processos econômicos descritos pelo uso de energia } \\
\text { e o Il Princípio da Termodinâmica. }\end{array}$ \\
\hline Charles Hall & $\mathbf{1 9 8 0}$ & Divulgação do conceito de ecossistemas industriais. \\
\hline $\begin{array}{c}\text { Jacques } \\
\text { Vigneron }\end{array}$ & $\mathbf{1 9 8 0}$ & $\begin{array}{c}\text { Um dos primeiros a lançar o conceito de ecologia } \\
\text { industrial }\end{array}$ \\
\hline $\begin{array}{c}\text { Robert } \\
\text { Frosch }\end{array}$ & 1989 & $\begin{array}{c}\text { Escrevem o artigo "Estratégias da Manufatura", na } \\
\text { revista Scientific American. }\end{array}$ \\
$\begin{array}{c}\text { Nicolas } \\
\text { Gallopoulos }\end{array}$ & & $\begin{array}{c}\text { Lançam a idéia de desenvolver métodos de produção } \\
\text { Ondrial que terá menos impacto sobre o ambiente. }\end{array}$ \\
\hline
\end{tabular}




\begin{tabular}{ccc}
\hline $\begin{array}{c}\text { Braden } \\
\text { Allenby }\end{array}$ & 1992 & $\begin{array}{c}\text { É o autor da primeira tese de doutorado que contém } \\
\text { muitas das idéias envolvidas no desenvolvimento da } \\
\text { ecologia industrial. }\end{array}$ \\
\hline $\begin{array}{c}\text { Hardin Tibbs } \\
\begin{array}{c}\text { Don } \\
\text { Huisingh } \\
\text { (Ed.) }\end{array}\end{array}$ & 1994 & $\begin{array}{c}\text { The Greening of Industrial Ecosystems: o primeiro } \\
\text { livro sobre Ecologia Industrial. }\end{array}$ \\
\hline $\begin{array}{c}\text { Reid Lifset } \\
\text { (Ed.) }\end{array}$ & 1997 & $\begin{array}{c}\text { "Industrial Ecology. Environmental Agenda for } \\
\text { Frosch e Gallopoulos, com a linguagem e retórica do } \\
\text { mundo dos negócios. }\end{array}$ \\
\hline
\end{tabular}

É comum associar os princípios de ecologia industrial ao artigo "Estratégias da Manufatura", escrito por Robert Frosch e Nicholas Gallopoulos (1989) para a edição especial da Scientific American intitulada "Managing Planet Earth". Nele, os autores argumentam ser possível desenvolver métodos de produção menos danosos ao meio ambiente, substituindo-se os processos isolados por sistemas integrados, os quais chamaram de ecossistemas industriais. Esses sistemas modificariam, tanto quanto possível, a lógica de produção isolada, baseada apenas na utilização de matérias-primas resultando em produtos e resíduos, substituindo-a por sistemas que possibilitassem o aproveitamento interno de resíduos e subprodutos, reduzindo as entradas e saídas externas (ARAÚJO et al, 2012).

Apesar das ideias apresentadas por Frosh e Gallopoulos (1989) não serem totalmente originais, uma vez que outros autores já haviam estudado os impactos ambientais por este viés, este artigo é considerado o primeiro passo no desenvolvimento da ecologia industrial.

Em 1991, a National Academy of Science considerou o desenvolvimento da ecologia industrial como um novo campo de estudo. Em 1994, foi publicado o primeiro livro sobre o tema The Greening of Industrial Ecosystems, que identifica as ferramentas da ecologia industrial, como o Projeto para 0 Ambiente, a Avaliação de Ciclo de Vida e a contabilidade ambiental (ARAÚJO et al, 2012). 
Em linhas gerais, a Ecologia Industrial está alicerçada em 3 bases primárias (Figura 2.8), das quais se chega ao desenvolvimento sustentável, descritas a seguir (ALVES; OLIVEIRA, 2007):

(i) Meio ambiente, de onde e como é extraída a matéria-prima, como as fibras têxteis, por exemplo, que requer o equilíbrio entre proteção do ambiente físico e seus recursos, bem como a capacidade da natureza para absorver as alterações sofridas e se recuperar das agressões do homem;

(ii) Economia, que requer a união entre o ecologicamente correto com ganhos financeiros, gerando o aumento da facilidade ao acesso de recursos, de oportunidades e da prosperidade;

(iii) Social, que visa o oferecimento de recursos e ferramentas dignas de trabalho e a promoção da qualidade de vida. Logo, não é aceito pelos ecologistas e estudiosos da área ambiental que uma empresa tenha uma produção industrial sustentável, mas que para isso se utilize de mão-de-obra escrava, infantil ou desumana, como é visto, em alguns casos, nas lavouras do cultivo de algodão ou mesmo nas confecções.

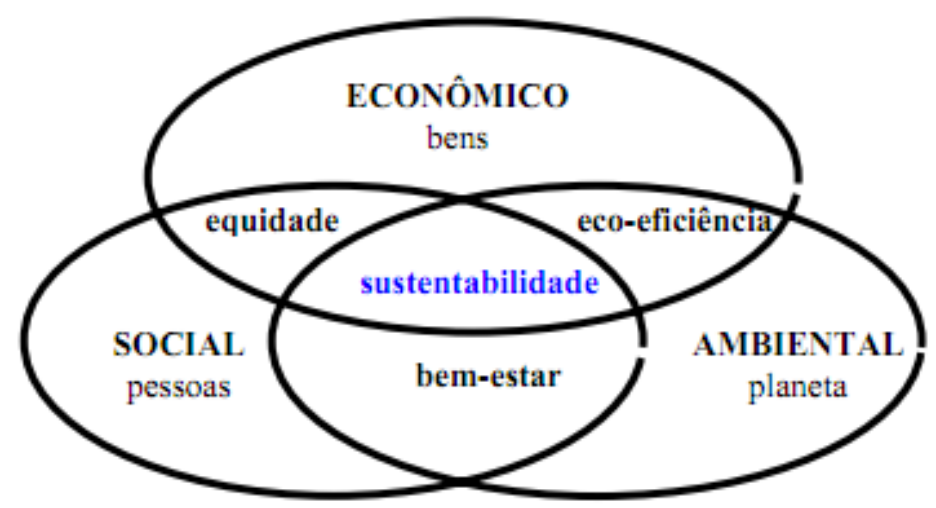

Figura 2.8. As bases primárias da Ecologia Industrial (ALVES; OLIVEIRA, 2007) 
A ecologia industrial, entre outros princípios, utiliza-se do conceito de metabolismo industrial. (Figura 2.9). Nele, cada indústria é tratada como um "organismo", e nestes organismos entram matérias-primas/recursos e energia e saem produtos e resíduos, que poderiam ser processados novamente (ALMEIDA; GIANNETTI, 2009).

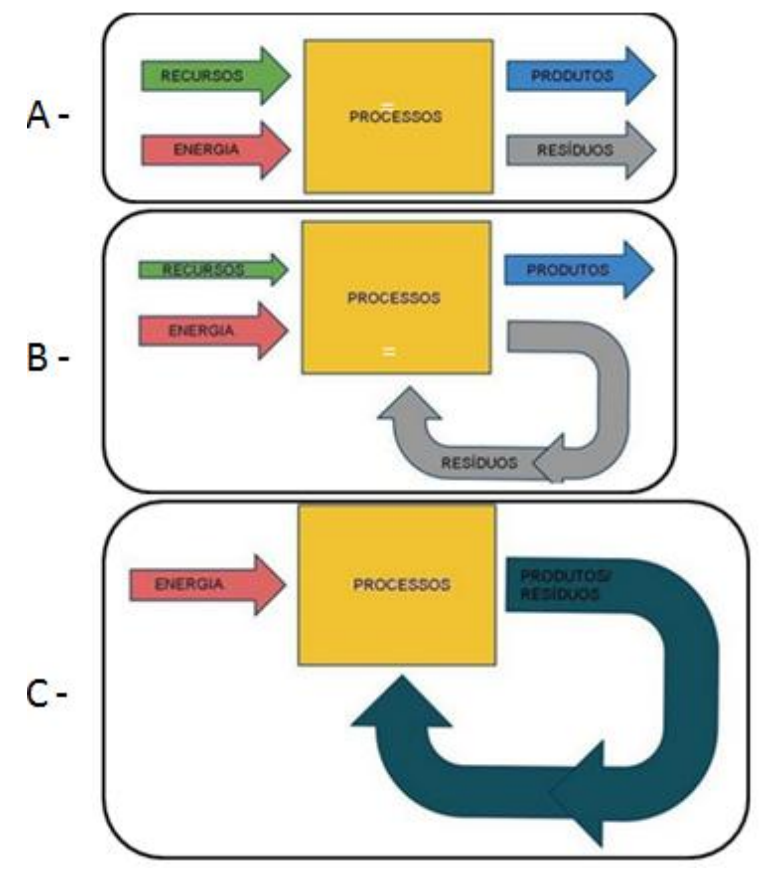

Figura 2.9. Metabolismo Industrial: (a) na primeira etapa deste processo evolutivo, as indústrias consideram que os recursos são infinitos e capacidade de absorção da natureza é igualmente infinita; (b) numa etapa, mais "ecológica", as indústrias passaram (ou passarão) a reciclar seus resíduos, diminuindo a tomada de recursos, até mutuamente em interações diversas; (c) num sistema totalmente integrado, as indústrias passariam a reciclar totalmente os resíduos, passando o sistema a necessitar somente de energia (ALMEIDA; GIANNETTI, 2009)

Há ainda outros conceitos empregados na produção industrial ecologicamente correta, antes mesmo do emprego dos conceitos da ecologia industrial, dentre eles:

(i) Programas de Prevenção à Poluição: constituem uma abordagem de gerenciamento ambiental que prioriza a 
redução dos resíduos na fonte como forma de preservar os recursos naturais e reduzir o desperdício de materiais, água e energia, em contraposição à abordagem tradicional, que se apoia nas tecnologias de controle e tratamento de resíduos (ALMEIDA; GIANNETTI, 2009). Deste modo, a Prevenção da Poluição (P2) é uma estratégia de redução de poluição chave em muitos países, apesar de seu sucesso ser limitado na melhoria do desempenho ambiental. A P2 pode relacionar-se, por exemplo, em mudanças processuais, mudanças de entrada e saída de materiais e equipamentos, alterações de produtos, análise custo-benefício e fatores relacionados, entre outros (HARRINGTON, 2012);

(ii) Produção Limpa: nesse processo há somente uma mudança na cadeia produtiva, corrigindo perdas e usos excessivos de determinados insumos, gerando um "produto limpo" (CETESB, 2012);

(iii) Produção Mais Limpa $(\mathrm{P}+\mathrm{L})$ (Figura 2.10): aplicação contínua de uma estratégia econômica, ambiental e tecnológica integrada aos processos e produtos, a fim de aumentar a eficiência no uso de matérias-primas, água e energia, através da não-geração, minimização ou reciclagem de resíduos gerados em um processo produtivo (CETESB, 2012). Dessa forma, a $\mathrm{P}+\mathrm{L}$ contribui para ampliar a sustentabilidade dos sistemas naturais, tanto pela redução da necessidade de insumos para um mesmo nível de produção, quanto pela redução da poluição resultante do processo de produção, distribuição e consumo (LUMI, 2009). 


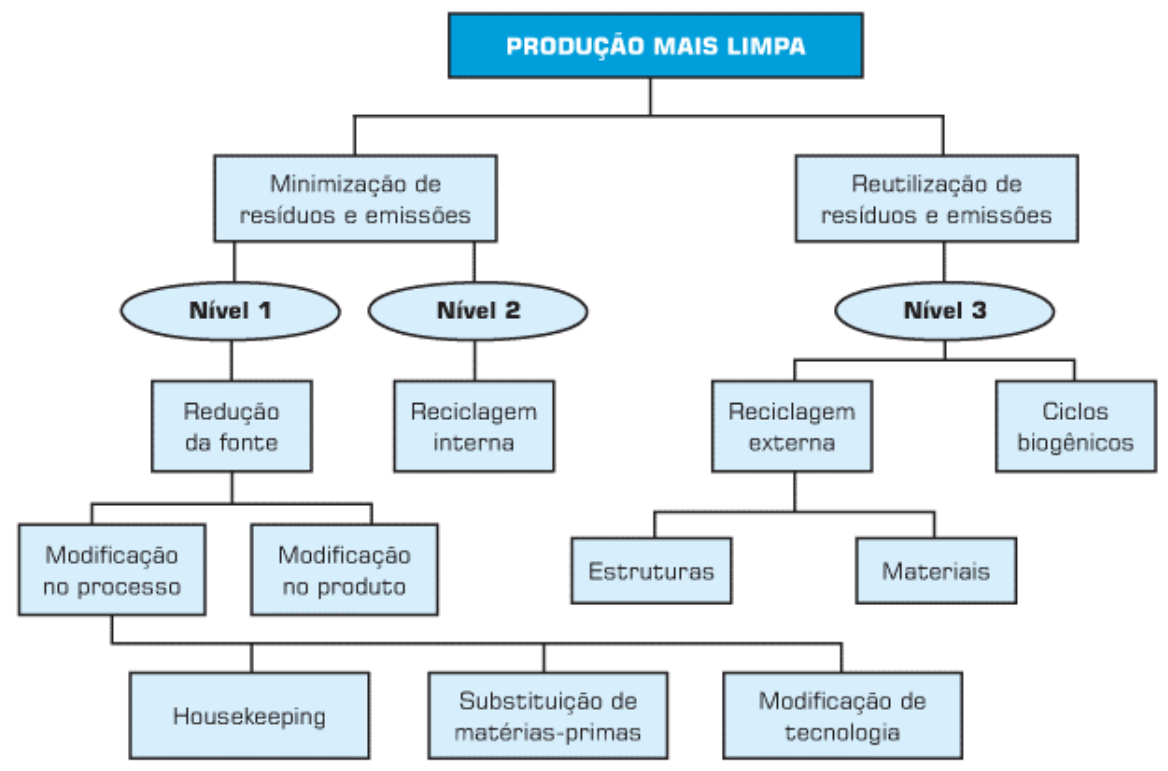

Figura 2.10. Metodologia da Produção mais Limpa ( $P+L)$ (ALVES; OLIVEIRA; 2007)

$\mathrm{Na}$ Tabela 2.5 apresenta-se um exemplo da metodologia da $\mathrm{P}+\mathrm{L}$ utilizada numa indústria têxtil.

Tabela 2.5. Exemplo de aplicação de Produção Mais limpa na indústria têxtil (ALMEIDA; GIANNETTI, 2009)

\begin{tabular}{|c|c|c|c|}
\hline Empresa & Problema & $\begin{array}{c}\text { Medidas } \\
\text { Implantadas }\end{array}$ & Resultados \\
\hline $\begin{array}{l}\text { Cermatex - Indústria } \\
\text { de Tecidos Ltda. }\end{array}$ & $\begin{array}{l}\text { Elevada carga } \\
\text { orgânica no efluente } \\
\text { gerado no processo } \\
\text { de engomagem. }\end{array}$ & $\begin{array}{l}\text { Substituição do } \\
\text { amido natural bruto } \\
\text { por amido solúvel. } \\
\text { Instalação de } \\
\text { tanques de } \\
\text { armazenagem de } \\
\text { goma para } \\
\text { recozimento. } \\
\text { Reestudo geral das } \\
\text { formulações de } \\
\text { gomas. }\end{array}$ & $\begin{array}{c}\text { Redução de } 50 \% \text { na } \\
\text { carga orgânica do } \\
\text { efluente gerado. } \\
\text { Diminuição no } \\
\text { consumo de amidos. } \\
\text { Redução de } 10 \% \text { no } \\
\text { consumo de água e } \\
\text { de energia no } \\
\text { processo de } \\
\text { beneficiamentp. } \\
\text { Redução de } 1,5 \% \text { no } \\
\text { custo final do } \\
\text { produto. }\end{array}$ \\
\hline
\end{tabular}

A ecologia industrial poderia ser definida, então, como um campo de pesquisa que visa minimizar e aperfeiçoar os processos industriais, gerando menos resíduos, gastando menos energia e fazendo com que a natureza sinta menos os impactos da modernidade. $\mathrm{Na}$ indústria têxtil, por exemplo, as 
ourelas de tecidos produzidas na tecelagem são previsíveis e geradas pelo próprio equipamento construído inadequadamente. O "desperdício" (LÖBACH, 2001) incorporado ao processo - cujo significado original da palavra é "fios, que não servindo para tecelagem, se empregam na limpeza de máquinas; estopa" - demonstra sua relação com o destino previsível (FINKIELSZTEJN, 2006).

Verifica-se então que os processos poderiam ser melhorados, reduzindo os impactos ambientais. Os custos finais da produção, como energia, mão de obra, transporte, entre outros, são repassados ao produto final e, consequentemente, também repassados ao consumidor. Constata-se que as demandas do mercado foram supridas, havendo inclusive lucro por parte das empresas, mas sem um devido controle e preocupação com o meio ambiente.

A ideia da ecologia industrial é também traçar uma analogia com os ecossistemas, permitindo fechar os ciclos de materiais e energia com a formação de uma eco rede, que imita os ciclos biológicos fechados. Ou seja, tudo o que é produzido dentro desta rede é reutilizado, não havendo desperdícios e/ou resíduos.

Assim, o foco na ecologia industrial se relaciona com uma produção industrial mais limpa, com melhores desempenhos no campo ambiental e também econômico, dentre outros conceitos.

A ecologia industrial fornece meios eficientes para que determinado produto seja produzido dentro de padrões estabelecidos por órgãos da área ambiental, como a ISO (International Organization for Standardization), que certifica produtos ambientalmente corretos a exemplo do selo verde ISO 14.001, visando aperfeiçoar a produção, gerando menos resíduos e gastando menos energia (GIANNETTI et al, 2008).

\subsubsection{Ferramentas da Ecologia Industrial: Avaliação do Ciclo de Vida}

Entre as décadas de 1950 e 60, o foco dos estudos ambientais estava na disposição das matérias primas e/ou insumos. Foi o início do desenvolvimento de padrões de qualidade e de emissão de poluentes, havia a diluição de resíduos e emissões nas águas e no ar e a uma inexistência quase total de responsabilidade empresarial. Nas décadas de 1970 e 80 o foco estava 
no tratamento dos resíduos. Era o início do sistema de licenciamento e impacto ambiental, a aplicação do Tratamento de Final de Tubo era a saída mais utilizada pelas empresas e sua responsabilidade era isolada, não havendo uma atitude pró-ativa, mas sim reativa. Da década de 1990 até agora, o foco está na prevenção da poluição, uma vez que há instrumentos econômicos e códigos voluntários de conduta, além de uma atitude pró-ativa em solucionar problemas ambientais e o emprego de tecnologias limpas no sistema produtivo e a utilização da Análise do Ciclo de Vida (CENTRO NACIONAL DE TECNOLOGIAS LIMPAS, 2012).

Entre os vários instrumentos sustentáveis aplicáveis às indústrias do setor de têxtil e moda, a Avaliação ou Análise do Ciclo de Vida torna-se uma ferramenta indispensável para a avaliação dos impactos ambientais causados pelos produtos do setor.

Segundo SETAC (1993) (Figura 2.11):

A avaliação inclui o ciclo de vida completo do produto, processo ou atividade, ou seja, a extração e o processamento de matérias-primas, a fabricação, o transporte e a distribuição; o uso, o reemprego, a manutenção; a reciclagem, a reutilização e a disposição final.

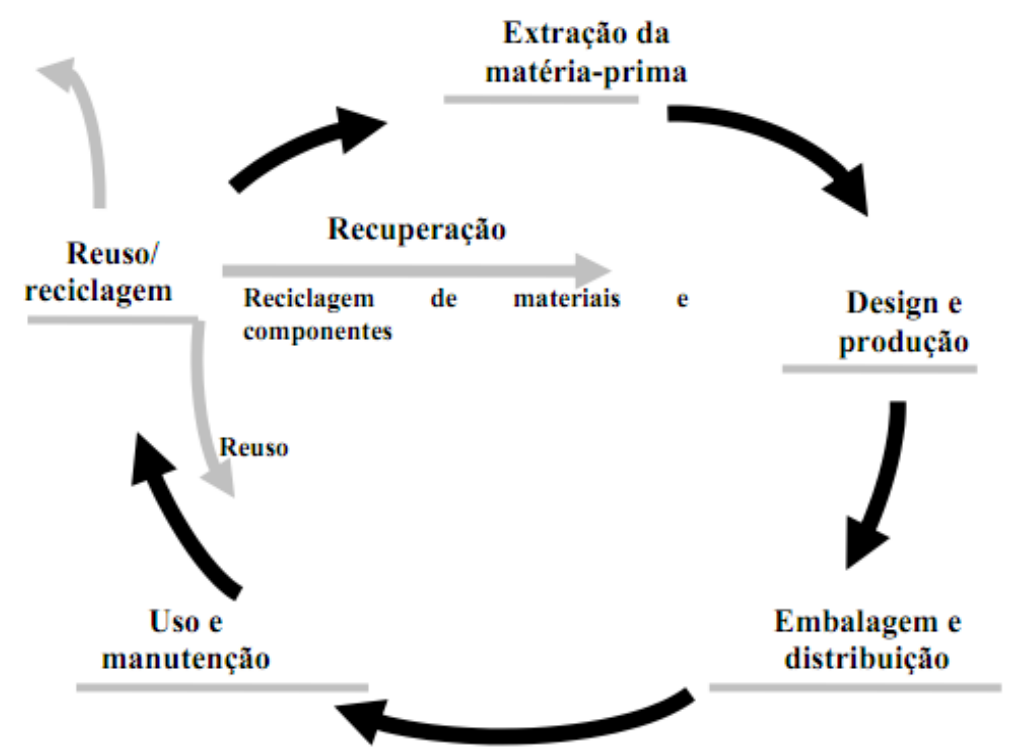

Figura 2.11. Esquema simplificado do conceito de Ciclo de Vida dos produtos (ALMEIDA; GIANNETTI, 2009) 
Vários autores (JENSEN, 1997; CHEHEBE, 1998; GRAEDEL, 1998; LIMA, 2007) descrevem a ACV como sendo um instrumento de avaliação do impacto ambiental associado a um produto ou processo cuja abrangência compreende etapas que vão desde a retirada das matérias-primas elementares da natureza que entram no sistema produtivo (berço) à disposição do produto final após uso (túmulo). A ACV trata-se de uma técnica de apoio ao gerenciamento ambiental e de desenvolvimento sustentável.

A Política Nacional dos Resíduos Sólidos, Lei no 12.305 de 2 de agosto de 2010, caracteriza a Avaliação do Ciclo de Vida no parágrafo II, $7^{\circ}$ artigo, como sendo um "estudo das consequências dos impactos ambientais causados à saúde humana e à qualidade ambiental, decorrentes do ciclo de vida do produto" (BRASIL, 2011).

A Avaliação do Ciclo de Vida estuda o desempenho ambiental de um produto durante o seu manufaturamento, passando por todas as etapas que potencialmente podem ser impactantes ao meio ambiente, além de compreender também as interações necessárias para a produção do bem, assim como seu papel na sociedade durante e após o seu consumo. Todo produto tem uma "vida" que começa com o seu planejamento e com a extração dos recursos naturais que vão possibilitar a sua existência. A sua produção e o seu uso/consumo são as fases seguintes, e, finalmente, o produto passa pelas atividades do fim de sua "vida" (coleta/separação, reuso, reciclagem, disposição dos resíduos) (LIMA, 2007).

A ACV permite que seja feita uma comparação de desempenho de diferentes produtos com uma mesma função social no ambiente. Para o setor de têxtil e moda, a utilização da ACV é útil para que se tenha a comprovação, por exemplo, de qual tipo de fibra ou peça de vestuário desempenha uma melhor função ao processo que se destina, bem como verificar o potencial reciclável das mesmas, além da análise se basear na norma ISO 14040, cuja finalidade é a da promoção de uma rotulagem ambiental. $O$ objetivo da rotulagem ambiental é buscar a melhoria da qualidade ambiental de produtos e processos mediante a mobilização das forças de mercado pela conscientização de consumidores e produtores (CORREA, 1998). Existem 3 tipos de rotulagem (PREUSSLER et. al, 2007): 
(i) Rotulagem Tipo I - NBR ISO 14024 - Programa Selo Verde: Estabelece os princípios e procedimentos para o desenvolvimento de programas de rotulagem ambiental, incluindo a seleção, critérios ambientais e características funcionais dos produtos, e para avaliar e demonstrar sua conformidade. Também estabelece os procedimentos de certificação para a concessão do rótulo;

(ii) Rotulagem Tipo II - NBR ISO 14021- Auto declarações ambientais: Especifica os requisitos para auto declarações ambientais, incluindo textos, símbolos e gráficos, no que se refere aos produtos. Termos selecionados em declarações ambientais e fornece qualificações para seu uso. Descreve uma metodologia de avaliação e verificação geral para auto declarações ambientais e métodos específicos de avaliação e verificação para as declarações selecionadas nesta Norma;

(iii) Rotulagem Tipo III - ISO 14025 - Inclui a Avaliação do Ciclo de Vida: Ainda está sendo elaborada no âmbito da ISO. Tem alto grau de complexidade devido á inclusão da ferramenta ACV. A incorporação deste tipo de rotulagem pelo mercado ainda é tímida.

As etapas necessárias para desenvolver um estudo sobre o ciclo de vida de um produto são:

(i) Definição dos objetivos e escopo do trabalho, que devem ser claramente definidos e consistentes com a aplicação pretendida. A sua definição deve incluir, de forma clara, os propósitos pretendidos e conter todos os aspectos considerados relevantes para direcionar as ações que deverão ser realizadas (CHEHEBE, 1998; LIMA, 2007);

(ii) Análise de inventário, que corresponde à fase de coleta e quantificação de todas as variáveis (matéria-prima, energia, transporte, emissões atmosféricas, efluentes líquidos, resíduos sólidos etc.) relacionadas 
com a análise de vida de um produto ou processo. A condução do inventário é um processo interativo. A sequência de eventos envolve a checagem de procedimentos de forma a assegurar que os requisitos de qualidade estabelecidos na primeira fase sejam obedecidos (CHEHEBE, 1998; LIMA, 2007);

(ii) Avaliação de impacto, que representa o entendimento e a avaliação da significância de impactos ambientais potenciais, usando os resultados da análise de inventário (CHEHEBE, 1998; LIMA, 2007). Utilizam-se procedimentos de cálculo e da coleta de dados, incluindo-se as regras para alocação de produtos e o tratamento dispensado à energia;

(iv) Interpretação dos dados, que compreendem os elementos necessários a uma correta análise por parte do leitor dos resultados obtidos na fase de análise do inventário (CHEHEBE, 1998; LIMA, 2007).

No contexto do estudo desenvolvido, estas quantificações numéricas e em bases comparáveis possibilitam contrastar os produtos têxteis, podendo apontar se a reciclagem é viável e se ela apresenta um benefício ambiental real. As fibras têxteis recicladas, por exemplo, deverão apresentar funcionalidade semelhante em um mesmo contexto para que haja uma compensação real na substituição destes materiais. A perda de funcionalidade pode exigir medidas compensatórias para igualar estas fibras, podendo aumentar o impacto ambiental delas.

\subsubsection{Avaliação do Ciclo de Vida (ACV) de Têxteis}

Há poucos estudos em relação à Avaliação do Ciclo de Vida de Têxteis. Alguns estudos mais recentes na área têxtil (DÄHLOOF, 2004; ADEME, 2006; ARDUIN e PACCA, 2010), além de quantificar, também correlacionaram, através da aplicação de diferentes métodos na etapa de avaliação do impacto do ciclo de vida, o consumo e as emissões dos processos a diferentes categorias de impacto, sendo então classificados como estudos de ACV. 
Os impactos mais avaliados foram, respectivamente, consumo de energia, aquecimento global, acidificação, eutrofização, ecotoxicidade e formação de ozônio troposférico (ARDUIN; PACCA, 2010).

Os resultados dos estudos sobre ACV em têxteis, contudo, não foram totalmente eficientes, pois a unidade funcional variou bastante no que tange a composição dos artigos têxteis. Os autores desses estudos utilizaram as fibras de algodão e poliéster em seus estudos, notoriamente as mais consumidas mundialmente, ora separadas, ora juntas no mesmo artigo. Além dos produtos avaliados serem diferentes e terem dificultado a análise dos resultados, também parte destes estudos delimitou como fronteira do sistema de produto apenas algumas etapas do ciclo de vida e não o ciclo total (ARDUIN; PACCA, 2010).

Ao comparar resultados e variáveis utilizadas em estudos sobre ACV, há a necessidade de se reportar claramente quais as variáveis consideradas e elas devem se equiparar. ADEME (2006), definiu como unidade funcional uma calça jeans que foi utilizada uma vez por semana durante 4 anos e lavada cerca de 70 vezes antes de ser descartada. Levi Strauss \& Co. (2009) considerou como unidade funcional uma calça jeans Levi's $501^{\circledR}$ utilizada uma vez por semana durante 2 anos, ou seja, usada cerca de 104 vezes e depois descartada. Ainda comparando-se o potencial de aquecimento global de todo 0 ciclo de vida da calça jeans avaliada no estudo da ADEME (2006), que corresponde a $9,2 \mathrm{~kg} \mathrm{CO}_{2} \mathrm{eq}$, os resultados continuam notoriamente distintos (ARDUIN; PACCA, 2010) (Tabela 2.6).

Tabela 2.6. Comparação dos resultados e variáveis de estudos que realizaram a ACV para uma calça jeans (ARDUIN; PACCA, 2010)

\begin{tabular}{ccc}
\hline Estudo & $\begin{array}{c}\text { Unidade } \\
\text { Funcional }\end{array}$ & $\begin{array}{c}\text { Potencial de Aquecimento } \\
\text { Global }\end{array}$ \\
\hline ADEME, 2006 & Calça jeans utilizada 1 dia & $44 \mathrm{~g} \mathrm{CO}_{2 \mathrm{eq}}$ \\
\hline LEVI STRAUSS \& Co., 2009 & $\begin{array}{c}\text { Calça jeans utilizada uma vez } \\
\text { por semana em 2 anos }\end{array}$ & $32,5 \mathrm{Kg} \mathrm{CO}_{2 \mathrm{eq}}$ \\
\hline
\end{tabular}


Outra variável que influenciou no resultado dos estudos avaliados foi a periodicidade e o procedimento de manutenção dos produtos têxteis (lavagem, secagem e passadoria) realizados na fase de uso. Um estudo comparativo entre uma camiseta 100\% algodão produzida na Índia e uma jaqueta 100\% poliéster produzida na China, ambas consumidas na Alemanha, mostrou que a camiseta teve seu maior impacto ambiental na fase de uso na Alemanha, representando $70 \%$ do consumo de energia e emissão de $\mathrm{CO}_{2}$, enquanto que os maiores impactos da jaqueta ocorreram na fase de produção na China (ARDUIN; PACCA, 2010).

Observando também o escopo geográfico, há de se considerar os diferentes modos de conservação do artigo têxtil, como produtos químicos empregados em sua limpeza, a temperatura de lavagem, os procedimentos de secagem e de passadoria, todos eles influenciando fortemente na análise final dos resultados da ACV. Contudo, é sugerida que a conservação é a etapa mais poluente do ciclo de vida têxtil (WASTE ON LINE, 2011).

Outra pesquisa, realizada no Reino Unido, afirma que se cada pessoa reutilizasse uma peça do vestuário, o suéter de lã, ao invés de comprar uma peça nova todo inverno, seria poupado uma média de 371 milhões de galões (aproximadamente 1.400 milhões de litros de água) (WASTE ON LINE, 2011).

\subsubsection{Reciclagem e Reutilização}

Reciclagem designa o reaproveitamento de materiais manufaturados como matéria-prima para um novo produto, empregando processos químicos e/ou mecânicos para isso; já a reutilização se refere em utilizar um material já manufaturado como matéria-prima em um novo produto, não havendo a necessidade de intervenções químicas e/ou mecânicas no processo (RECICLÁVEIS, 2012).

No segmento têxtil, um exemplo de reciclagem é a transformação de garrafas PET (polietileno tereftalato) em fios que servirão de matéria prima para um novo tecido. O grupo Mossi \& Ghisolf, detentora da marca Alya Eco®, lançou no mercado uma fibra de poliéster reciclada produzida $100 \%$ das embalagens PET. A Alya Eco® é mais fina que uma fibra de algodão, tendo sua espessura relativa em 1,4 Dtex, o que se traduz em roupas de toque 
agradável, ótimo caimento e confortáveis. Para produzir uma camiseta básica mista com $50 \%$ de algodão, são necessárias 2 garrafas PET de 2 litros (ALYA ECO, 2012).

Outro exemplo de reciclagem têxtil é o da Tavex Corporation que desenvolveu o Ecol Denim $\AA$, produzido a partir da mistura de fibras novas e retalhos de tecidos reciclados $100 \%$ algodão. Para a produção deste denim, a empresa reaproveita os retalhos de suas fábricas e compra por quilo os refugos têxteis de outras confecções do país, sendo o produto final composto por $25 \%$ de fibras recicladas. A empresa afirma ser necessário para a fabricação deste tipo de material um investimento de US\$ 55 milhões em equipamentos para reciclagem, havendo, contudo, uma economia no produto final de até $15 \%$ em relação ao processo convencional. Dentre outros produtos com marketing ecológico, também anunciou a confecção de um outro tecido que leva $23 \%$ de fibras de PET reciclada com economia de $10 \%$ a $15 \%$ no preço final (RECICLÁVEIS, 2012).

Contudo, pelo terceiro ano consecutivo, o setor de nãotecidos e tecidos técnicos reforça sua posição como maior reciclador de PET no Brasil, processando $27 \%$ deste plástico. Segundo a definição normatizada da ABNT (2002), em conformidade com a NBR13370, nãotecido "é uma estrutura plana, flexível e porosa constituída de véu ou manta de fibras ou filamentos orientados direcionalmente ou ao acaso, consolidadas por processo mecânica (fricção) e/ou químico (adesão) e/ou térmico (coesão) ou combinação destes". Já os têxteis técnicos são definidos como produtos usados pela sua performance, pelas suas características funcionais para aplicações não dirigidas ao consumidor ou para aplicações industriais. A definição depende do uso final do produto e não no tipo de fio ou fibra usados (CENESTAP, 2004).

O setor transforma as garrafas e embalagens em carpetes, forros de carros, geotêxteis, cordas, fios, entre outros insumos empregados em setores fundamentais da economia como o automotivo, de infraestrutura, construção civil, entre outros (REVISTA FATOR, 2011).

Em 2010, o setor recuperou cerca de 76 mil toneladas de PET no país, sendo 46 mil toneladas empregadas na produção de nãotecidos e 30 mil em tecidos técnicos. As aplicações de PET reciclado em nãotecidos estão entre as que mais cresceram nos últimos três anos, com o aumento de 7,4\% no 
período, segundo a ABIPET - Associação Brasileira da Indústria do PET (REVISTA FATOR, 2011).

Quando se utilizam retalhos para fazer artesanato como fuxico ou o patchwork, que são trabalhos manuais feitos de pedaços de tecidos emendados, diz-se que houve a reutilização do material (Figura 2.12). Geralmente, tais técnicas são desenvolvidas e disseminadas por meio de Cooperativas e ONG's (organizações não-governamentais) ligadas ao setor de têxtil e moda.

Cooperativa define-se por ser um grupo de pessoas com um mesmo objetivo, que trabalham juntas e repartem a riqueza adquirida, onde valores de igualdade, democracia e fraternidade são pontos fortes na formação deste coletivo. Geralmente, observa-se a existência de cooperativas de catadores de resíduos, onde trabalhadores informais são responsáveis por $90 \%$ da matériaprima que alimenta a indústria da reciclagem no país (IPT-SEBRAE, 2003).

No ano de 2003, a Prefeitura de São Paulo firmou um acordo com a ABIT para a criação de 600 postos de trabalho no projeto de uma Cooperativa intitulada "Tecendo Novos Caminhos - Formação e Inclusão Social: Cooperativa de Resíduos Têxteis" (ABIT, 2012). Entre os objetivos ambientais, pretendia-se reciclar e reutilizar o resíduo têxtil descartado nas regiões do Brás, Bom Retiro, Mooca, Pari, Belém e Sé. No Rio de Janeiro, a COOPA-ROCA, Cooperativa de Trabalho Artesanal e de Costura da Rocinha Ltda., é uma cooperativa que capacita, coordena e gerencia o trabalho de mulheres moradoras da Rocinha, as quais produzem peças artesanais focadas no mercado da moda e do design (COOPA-ROCA, 2012).

As ONG's ou Organizações Não Governamentais são espécies de "empresas" do terceiro setor, sem fins lucrativos, e que desenvolvem ações sociais principalmente onde o Estado não consegue chegar, a fim de melhorar a qualidade de vida de determinada comunidade ou grupo de indivíduos. Como exemplo, a ONG Impacto Social, juntamente com a Escola Têxtil Fundamas, ambas localizadas em Joinville - SC, uniram-se em 2011 para transformar banners, que seriam descartados, em aventais de proteção. Esses aventais foram doados a três Associações de Separadores de Lixo da região, a Recipar, a Cooperanti e a da comunidade Rio do Ferro (PORTAL JOINVILLE, 2012). 


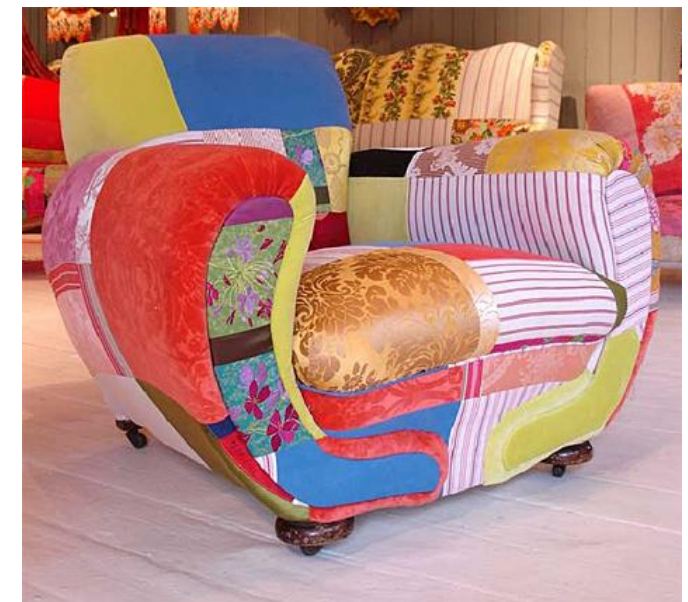

(a)

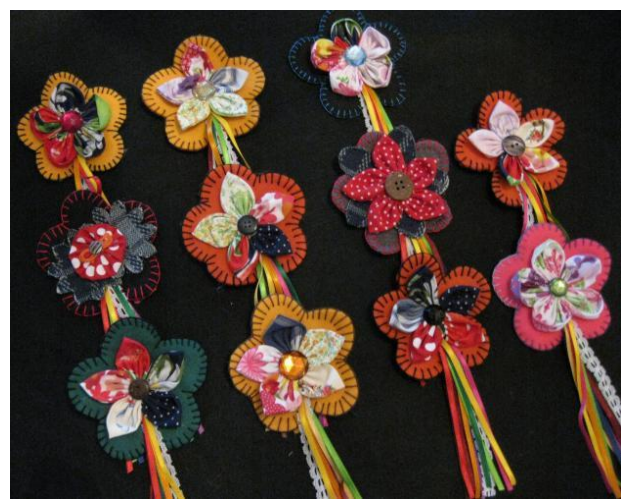

(c)

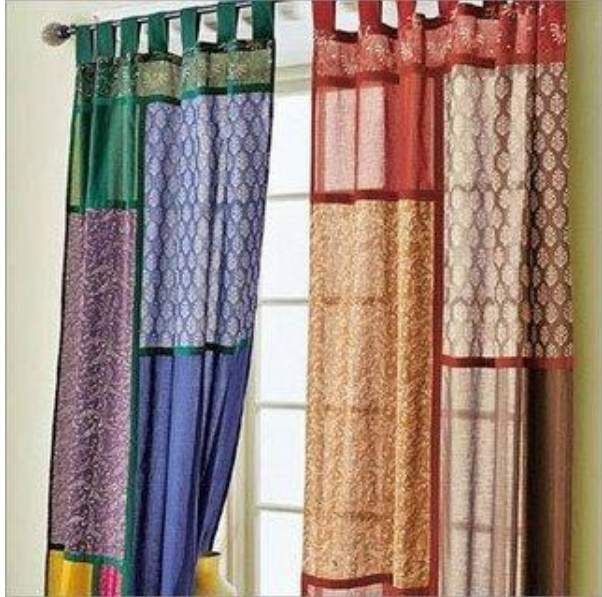

(b)

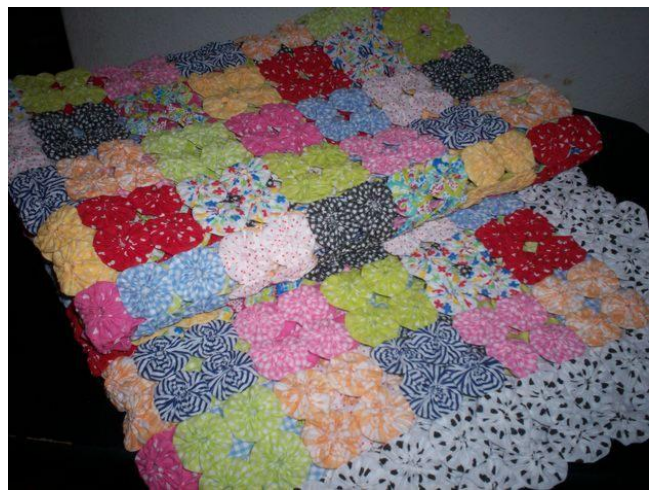

(d)

Figura 2.12. Exemplos de reutilização de tecidos: (a) Poltrona (RAFAELLA HARDMAN, 2012) e (b) cortina de patchwork (DONA DE CASA, 2012); (c) broches (CULTURA MIX, 2012) e (d) colcha de fuxicos (OLX, 2012)

\subsubsection{A Reciclagem de Resíduos Sólidos no Brasil e Uma Breve Comparação com o Reino Unido}

A pesquisa da Associação Brasileira de Empresas de Limpeza Pública e Resíduos Especiais - ABRELPE (2010) indicou um crescimento na taxa de geração de resíduos sólidos em 6,8\% desde o ano de 2009, não havendo um crescimento populacional proporcional no mesmo ritmo, o que levou a um aumento da geração de resíduos sólidos urbano per capita no país.

Já o recolhimento de resíduos sólidos apresentou um aumento no país, indicando uma melhora na cobertura deste serviço. A destinação dos resíduos ainda segue caminhos não ecológicos, principalmente como a incineração 
$(31,8 \%)$, o aterro $(27,5 \%)$ e lixão $(15,4 \%)$. Não há dados amplos e precisos sobre reciclagem e reutilização do lixo recolhido (ABRELPE, 2010).

A região sudeste contribui com $53,1 \%$ de todos os resíduos sólidos totais coletados no país, sendo a região mais populosa do país. Neste contexto, $42,4 \%$ dos resíduos apresentam destinação inadequada. Os investimentos no recolhimento de resíduos sólidos urbanos aumentaram no período entre 2009 e 2010, sendo refletido em um melhor funcionamento deste sistema. Assim como os resíduos sólidos urbanos, os resíduos derivados de construções e resíduos de serviços de saúde também foram mais amplos no ano de 2010. As principais destinações dos resíduos são, em ordem decrescente de quantidade, aterros sanitários, aterros controlados e lixões (ABRELPE, 2010).

A coleta seletiva aparece presente em $57,6 \%$ dos municípios brasileiros, sendo mais expressiva no sul e sudeste. Este setor apresentou um aumento em seus principais componentes - papel, plástico, vidro e alumínio - nos últimos dez anos, indicando uma evolução das políticas públicas e empresariais no sentido de reincorporar os resíduos na cadeia de produção.

Além de ser a região mais populosa, a região sudeste ainda é aquela que mais tem iniciativas de reciclagem e coleta seletiva no país. O Estado de São Paulo alcançou em 2010 uma população estimada em quase 40 milhões de habitantes que geram pouco mais de 55 mil toneladas/dia resíduos sólidos urbanos (ABRELPE, 2010).

No segmento da reciclagem, tem grande expressão empresarial a reintegração mecânica de plásticos, representando cerca de $42 \%$ das iniciativas empresariais (ABRELPE, 2010) e, principalmente, das latinhas e embalagens de alumínio, devendo considerar que já se instituiu uma "cultura da reciclagem" para este tipo de produto, o qual também possui um alto valor agregado. Há, aproximadamente, 1 milhão de catadores de sucata pelo país que usufruem desta matéria-prima como meio de geração de renda. O país reciclou, em 2005, 96,2\% das latas disponíveis no país, o que equivale a 127,6 mil toneladas de latas (ASSOCIAÇÃO BRASILEIRA DO ALUMÍNIO, 2012).

No que diz respeito às estatísticas referentes à reciclagem e reuso de têxteis no Brasil e no mundo, após uma pesquisa em diversas literaturas, concluiu-se que há uma carência de dados sobre esta área, embora - de maneira relativa, observou-se que os países europeus e os Estados Unidos 
possuem uma política de reciclagem e reuso de têxteis mais avançada que a do Brasil.

Comparando o Brasil com países europeus como os do Reino Unido um dos poucos dados mais precisos encontrados, onde a reciclagem e reutilização de resíduos sólidos atinge uma proporção considerável, o país ainda caminha de forma lenta para a sustentabilidade na área de têxtil e moda.

Os brasileiros, muitas vezes, desconhecem que praticamente todo tipo de resíduo sólido pode ser reciclado e/ou reutilizado, havendo a necessidade, obviamente, de métodos específicos para cada tipo de material. Esses métodos não são acessíveis para a maioria dos indivíduos ou não são amplamente divulgados, ao contrário do caso do alumínio ou até mesmo das garrafas PET.

Em relação aos têxteis, estima-se que no Reino Unido mais de 1 milhão de toneladas são jogados fora a cada ano, sendo a maior parte destes provenientes de fontes domésticas. Os têxteis compõem cerca de $3 \%$ do peso total do lixo doméstico gerado por uma família anualmente e são denominados de resíduos pós-consumo (WASTE ON LINE, 2011).

Muitos desses artigos são doados para lojas de caridades ou vendidos para brechós e lojas de trocas de produtos; contudo, muito material ainda é jogado no lixo convencional, indo parar nos aterros sanitários, como ocorre atualmente no Brasil. Na Tabela 2.7 apresentam-se os principais tipos de resíduos têxteis encontrados nos lixos domiciliares da população do Reino Unido. 
Tabela 2.7. Triagem e destinação dada aos têxteis do Reino Unido por meio de entidades como a Oxfam e a Wastesave (WASTE ON LINE, 2012)

\begin{tabular}{|c|c|c|c|}
\hline \multicolumn{4}{|c|}{ Têxteis que podem ser reutilizados } \\
\hline $\begin{array}{c}\text { Sapatos: } \\
\text { são } \\
\text { revendidos em países c } \\
\text { Paquistão, Índia, Áfrice } \\
\text { países do Leste Europ }\end{array}$ & $\begin{array}{l}\text { mo } \\
\text { e } \\
\text { u. }\end{array}$ & \multicolumn{2}{|c|}{$\begin{array}{c}\text { Roupas: } \\
\text { são revendidas no Reino Unido e no } \\
\text { exterior. A Oxfam fornece roupas } \\
\text { para Moçambique, Malawi e Angola } \\
\text { para uso emergencial, bem como o } \\
\text { fornecimento de roupas de inverno } \\
\text { para a ex-Jugoslávia, Albânia, } \\
\text { Afeganistão e para o Norte do Iraque. }\end{array}$} \\
\hline \multicolumn{4}{|c|}{ Têxteis que não podem ser reutilizados e são reciclados } \\
\hline $\begin{array}{l}\text { Calças, saias, etc.: } \\
\text { São vendidos para a } \\
\text { indústria de } \\
\text { reciclagem. Os itens } \\
\text { são triturados e } \\
\text { manufaturados } \\
\text { novamente para uso } \\
\text { em isolante acústico de } \\
\text { carros, forros para } \\
\text { telhados, cones de } \\
\text { alto-falante, } \\
\text { revestimentos de } \\
\text { painel, estofamento de } \\
\text { móveis, entre outros. }\end{array}$ & & $\begin{array}{l}\text { stuário de lã: } \\
\text { são } \\
\text { endidos para } \\
\text { empresas } \\
\text { ecializadas na } \\
\text { eciclagem e } \\
\text { ecuperação } \\
\text { essas fibras. }\end{array}$ & $\begin{array}{l}\text { Algodão e seda: } \\
\text { são separados por tipo } \\
\text { para a produção de } \\
\text { panos de limpeza, para } \\
\text { uso em indústrias } \\
\text { automobilísticas e } \\
\text { também para uso na } \\
\text { fabricação de papel. }\end{array}$ \\
\hline
\end{tabular}

Embora a maioria dos resíduos têxteis seja oriunda de fontes domésticas, eles também podem surgir durante a fabricação de fios e tecidos, processos de fabricação do vestuário e na indústria de varejo. Estes são denominados de resíduos pós-industriais. Juntos, tanto os resíduos pósconsumo quanto os resíduos pós-industriais, oferecem um vasto potencial de valorização e reciclagem.

No Reino Unido, a maioria dos tecidos pós-consumo são atualmente recolhidos por instituições de caridade, como o Exército da Salvação e a Oxfam (Oxford Committee for Famine Relief ou Comitê de Oxford de Combate à Fome), uma confederação de 13 organizações que atua em mais de 100 
países, inclusive no Brasil, em busca de soluções para o problema da pobreza através de campanhas, programas de desenvolvimento e ações emergenciais.

O doador tem a opção de colocar seus têxteis em bancos de coleta, levá-los às lojas de caridade ou tê-los apanhado por uma organização. A Recyclatex, um programa gerido pela Associação de Reciclagem de têxteis do Reino Unido em conjunto com as autarquias locais e instituições de caridade, oferece bancos de coleta de têxteis para uso público. O Exército de Salvação e Oxfam também usam um esquema de banco de coletas em conjunto com outros métodos, como, por exemplo, um serviço de recolha de têxteis porta a porta. Há cerca de 3 mil bancos de coleta de têxteis, mas que operam apenas com 25\% de sua capacidade total (WASTE ON LINE, 2011).

O Exército da Salvação é a maior operadora de bancos de coleta de têxteis no Reino Unido, com mais de 2 mil pontos em todo o país. Em média, cada um desses bancos recolhe cerca de 6 toneladas de tecidos por ano. Combinadas com as coletas porta a porta, as operações têxteis do Exército de Salvação recolhem cerca de 17 mil toneladas de roupas por ano (WASTE ON LINE, 2011).

As roupas são doadas a desabrigados, vendidas em lojas de caridade ou vendidas em países em desenvolvimento na África, no subcontinente indiano e em partes da Europa Oriental. Quase 70\% dos itens colocados em bancos de coleta são reutilizados, como roupas, e todos os itens não reutilizáveis são vendidos às indústrias especializadas para serem reciclados e utilizados como matérias-primas para panos de limpeza, dentre outros (WASTE ON LINE, 2011).

As roupas descartadas pelas entidades assistenciais são enviadas para Wastesave, situada na cidade de Huddersfield, na Inglaterra, uma entidade sem fins lucrativos com mais de 35 anos de atuação e focada na gestão de resíduos, como a reciclagem têxtil, onde processa cerca de 100 toneladas de roupas por semana. As roupas descartadas, separadas pela entidade e que não serviram para doação, são vendidas como matéria-prima para a indústria de reciclagem de têxteis (WASTE ON LINE, 2011).

No Brasil, a reciclagem industrial de tecidos pós-uso não é uma prática muito recorrente. No sul do país, maior reciclador de resíduos têxteis, existe o Banco do Vestuário, onde são recolhidas as aparas. O Banco de Vestuários é 
parte integrante do Projeto dos Bancos Sociais, coordenado pela Fundação Gaúcha dos Bancos Sociais da FIERGS - Federação das Indústrias do Estado do Rio Grande do Sul e seu presidente. Para a administração do Banco, o Presidente conta com Conselheiros do segmento empresarial, mais Conselheiros da Sociedade Civil, que possam oferecer sua contribuição ao Banco, tais como: Clubes de Serviços (Rotary ou Lions, por exemplo), Universidades, Escolas, Agências de Publicidade, Imprensa, Logística, Sindicatos, Federações, Associações, etc. (SBRT, 2008).

No Brasil, os resíduos têxteis podem ser reutilizados de algumas formas, tais como (RECITEX, 2012):

(i) Retalhos: são as sobras dos cortes das confecções, esse refugo é coletado nas indústrias têxteis por microempresas, geralmente familiares, que tem sua sede na redondeza das fabricas; eles fazem o trabalho de seleção e classificação dessas sobras; os pedaços maiores são chamados de "retalhos para limpeza" ou "aparas de malha", que são utilizados para limpeza de equipamentos gráficos; alguns retalhos também são reaproveitados para confecção de roupas infantis ou artesanatos.

(ii) Trapo mecânico: os retalhos menores são aproveitados para a confecção de "paninhos", conhecidos no Rio Grande do Sul como "trapo mecânico" e em São Paulo como "pastelão"; esses "trapos" são confeccionados manualmente um a um pelas microempresas

(iii) Estopas: são produzidos através do aproveitamento de desperdícios de fios e são classificados por cor e pela qualidade, sendo utilizados na fabricação de diversos tipos de estopas. Os fios brancos, $100 \%$ algodão, são os mais valorizados no mercado. Depois da seleção, esses fios são cortados em tamanhos menores e passam pelo processo de desfibragem, que rasga os fios. 
Na área de moda, poucas marcas nacionais, como a de jeanswear Éden ou a Osklen, reservam parte de seus investimentos com pesquisas de novas tecnologias e processos mais limpos de produção, dentre eles, o uso de corantes naturais de menor impacto no meio ambiente e uso de algodão orgânico, por exemplo. Outros exemplos da indústria têxtil no segmento de fiação, como o grupo Tavex Corporation e o grupo Cedro Têxtil, também investem nesta área, havendo programas de reciclagem dentro da própria empresa, que reutiliza os resíduos do próprio processo ou de outras confecções para a fabricação de novos fios ecologicamente corretos.

No segmento filantrópico de recolhimento, separação e doação de roupas, observa-se que o Brasil está consideravelmente atrasado em relação ao Reino Unido. Há poucos projetos que estimulam a doação e reutilização de peças de roupas, bem como poucas empresas que vivem da reciclagem de artigos têxteis para a fabricação de novos materiais e produtos.

Alguns exemplos filantrópicos é o da Casa Hope e o Bazar Unibes União Brasileiro-Israelita do Bem-Estar Social, situados na capital paulistana. Em ambos os casos, é aceito praticamente todo tipo de material para doação, como eletrodomésticos, móveis e artigos de decoração, além de peças de vestuário. As instituições possuem caminhões que retiraram as doações, dependendo do tamanho e do volume delas.

\subsubsection{Os Resíduos na Cidade de São Paulo}

No dia 06 de agosto de 2009 foi publicado o Decreto no 54.645 que regulamentou a Política de Resíduos Sólidos do Estado de São Paulo sob o governo do José Serra - ela havia sido instituída pela Lei $n^{0} 12.300$ de 16 de março de 2006 (ASSOCIAÇÃO BRASILEIRA DO ALUMÍNIO, 2012).

O Decreto teve como destaque a determinação da responsabilidade dos fabricantes, distribuidores ou importadores de produtos que, por suas características, geravam resíduos sólidos de significativo impacto ambiental, mesmo após o consumo desses produtos, pelo atendimento das exigências estabelecidas pelos órgãos ambientais e de saúde, especialmente para fins de eliminação, recolhimento, tratamento e disposição final, bem como para a mitigação dos efeitos nocivos que causem ao meio ambiente ou à saúde 
pública (ASSOCIAÇÃO BRASILEIRA DO ALUMÍNIO, 2012). É sabido que o referido decreto serviu como base para, mais tarde, em 2010, ser instituído em todo o Brasil a Política Nacional de Resíduos Sólidos, tema que será abordado mais profundamente no item 2.2.8 deste capítulo.

Tal decreto serviu também para que empresas como a Loga, uma das responsáveis pela coleta dos resíduos na cidade de São Paulo, otimizasse seus trabalhos em relação aos seus serviços de coleta, transporte, tratamento e destinação final dos resíduos domiciliares e dos serviços de saúde gerados no Agrupamento Noroeste do Município de São Paulo (LOGA, 2012).

No site da empresa, é possível conferir detalhadamente as ações implantadas, como o canal do cidadão, onde é possível encontrar informações sobre como e quando descartar os resíduos domiciliares e também informações sobre a coleta seletiva. Segundo Loga (2012):

\begin{abstract}
A coleta seletiva é um sistema de recolhimento de materiais como papéis, plásticos, vidros e metais, que podem ser reutilizados ou reciclados. Esse reaproveitamento utilizado na produção de materiais novos economiza matéria-prima, minimiza a quantidade de resíduos que seriam depositados no aterro sanitário e contribui com o desenvolvimento sustentável. O plástico da garrafa PET pode ser transformado, por exemplo, em cerdas de vassoura, em fibra para moletom, camisetas, artesanatos entre outros. Material que poderia sobrecarregar os aterros sanitários pelo não aproveitamento.
\end{abstract}

A Loga utiliza o "sistema porta a porta" em residências, comércios e indústrias para a recolha dos resíduos além de disponibilizar contêineres que podem ser instalados em condomínios residenciais ou comerciais. Também atua recolhendo o material depositado nos Pontos de Entrega Voluntária PEVs, espalhados por diversos bairros da cidade. Os materiais recicláveis coletados são levados até as centrais de triagem, indicadas pela Autoridade Municipal de Limpeza Urbana (AMLURB)/Limpurb e, na triagem, são separados de acordo com suas características físicas e encaminhados para as empresas que realizam a transformação desses resíduos em novos materiais Há materiais que tem preferência de reciclagem e venda, tal como metais. Outros resíduos, ainda que com potencial de reutilização, são identificados 
pelas cooperativas como rejeitos pela dificuldade de se encontrar consumidores que os comprem (LOGA, 2012).

Em conjunto com as empresas que realizam o serviço de varrição Paulitec, Delta, Unileste, Construfert e Qualix - e as equipes das Subprefeituras que realizam coleta de Grandes Objetos nas Operações Cata Bagulho, a Loga recolhe aproximadamente 15 mil toneladas de resíduos por dia. Os resíduos domiciliares que a LOGA coleta são destinados ao aterro de Caieiras, sob gestão da Empresa Essencis, enquanto a ECOURBS encaminha para o aterro sanitário localizado na região de Sapopemba e as outras empresas levam os resíduos a outros destinos diversos (LOGA, 2012).

A Loga coleta até 200 litros de resíduos por gerador (domicílio, loja ou fabricante), sendo que esta coleta ocorre pela disposição dos resíduos no exterior do local, os quais são posteriormente recolhidos pelos funcionários da empresa. Esta forma de coleta pode gerar incidentes, como o espalhamento destes resíduos nas calçadas pela ação de moradores de ruas ou pessoas que possam vir a se interessar pelo valor de mercado de parte desse material (LOGA, 2012).

Contratualmente, a Loga é também obrigada a recolher até $50 \mathrm{~kg}$ por dia/domicílio de resíduos de construção civil, desde que devidamente acondicionados. Assim, são diariamente coletadas entre 5,5 e 6 mil toneladas de resíduos, somente pela concessionária. Não propriamente na região de São Paulo, mas no que diz respeito à destinação, atualmente no Brasil, 42,5\% dos resíduos domiciliares coletados são destinados de forma inadequada (LOGA, 2012).

Os resíduos podem ter outras classificações, como os de varrição das ruas, recicláveis e de serviços de saúde. Das aproximadas 142 mil toneladas de lixo coletadas pela Loga mensalmente, apenas cerca de 1,5 mil toneladas são encaminhadas às cooperativas cadastradas na Prefeitura Municipal de São Paulo (LOGA, 2012).

Deste modo, a empresa opera coletando, diariamente, cerca de 6 mil toneladas de resíduos provenientes de 1,3 milhões de domicílios, hospitais, clínicas e similares, atendendo 7 milhões de munícipes - incluída a alta população flutuante na região (LOGA, 2012). 


\subsubsection{O Bairro do Bom Retiro: Polo de Moda Popular de São Paulo e Gerador de Resíduos}

Juntamente com os bairros da Barra Funda, Mooca e Brás, no final do século XIX, o bairro do Bom Retiro se tornou reduto de operários e de pessoas de baixa renda, concentrando, ainda hoje, cortiços e níveis discrepantes de renda entre seus moradores (GOMES; MARUM, 2005).

Em meados dos anos 1960, o bairro começou a ser conhecido por concentrar comércio de roupas e tecidos, passando também a ter confecções e pequenas empresas do ramo de têxtil e moda. Entre os povos encontrados no bairro, destacam-se os judeus, os bolivianos e principalmente os coreanos. A imigração, o multiculturalismo, a indústria têxtil e o comércio são elementos marcantes na dinâmica espacial e na paisagem do local (GOMES; MARUM, 2005).

Hoje em dia, o Bom Retiro se resume em ser um dos maiores polos comerciais de moda na cidade de São Paulo, onde se concentra grande quantidade de confecções que vendem no varejo ou atacado, comercializando roupas de moda feminina, masculina e infantil. Apresenta também nas adjacências comércio de bijuterias, armarinhos, tecidos planos e de malhas, e máquinas para confecção, que normalmente atendem às empresas locais e pequenos confeccionistas de São Paulo e região. O distrito do Bom Retiro contribuía no ano 2000 com 3,64\% dos empregos industriais da cidade, estando em 5 o lugar nessa atividade (EMPLASA, 2012).

Atualmente, nas comunidades coreana e hebraica estão os principais donos das confecções, juntamente com os bolivianos, principais protagonistas do cenário industrial do bairro, que vieram - em parte - de forma ilegal ao Brasil e são conhecidos por atuarem no segmento têxtil em trabalhos operacionais e de pouco reconhecimento, muitos dos quais sofrendo por não possuírem condições dignas de trabalho (GOMES; MARUM, 2005).

Os funcionários das centenas de pequenas confecções da região depositam nas ruas sacos com retalhos de tecido; na sequência, catadores de lixo e pessoas que produzem artesanato furam os sacos para recolher 0 material, deixando boa parte do lixo espalhado (DIÁRIO DE SP, 2011) (Figura 2.13). 

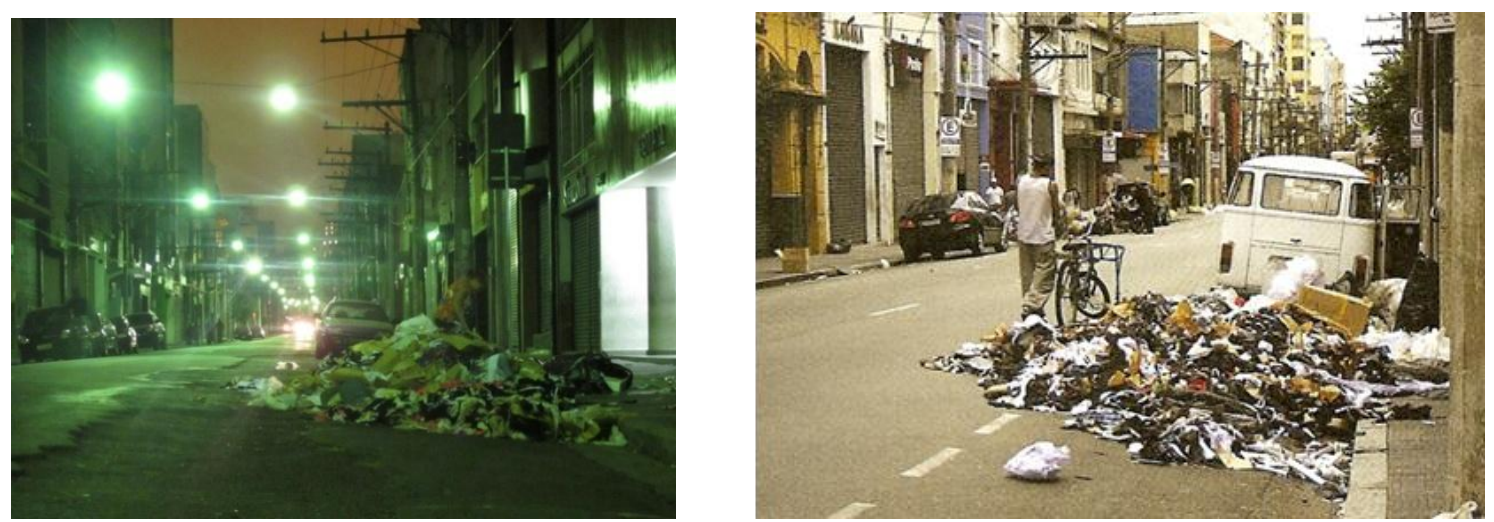

Figura 2.13. Refugos têxteis encontrados nas ruas do bairro do Bom Retiro (DIÁRIO DE SP, 2011)

A região conta com 1.200 confecções instaladas e a coleta de resíduos têxteis no bairro Bom Retiro é realizada de maneira pouco estruturada (CNI; ABIT, 2011). O bairro é um grande produtor de resíduos têxteis, aproximadamente 16 toneladas por dia e, normalmente, as aparas acabam em aterros sanitários (LOGA, 2011). Mesmo com um grande número de cooperativas trabalhando para o setor, os refugos não são totalmente eliminados por questões de logística, transporte e da pouca infraestrutura das próprias cooperativas.

Segundo uma pesquisa realizada pela $\mathrm{CNI}$ - Confederação Nacional das Indústrias e a ABIT (2012), o fluxograma atual dos resíduos têxteis do bairro é o seguinte (Figura 2.14):

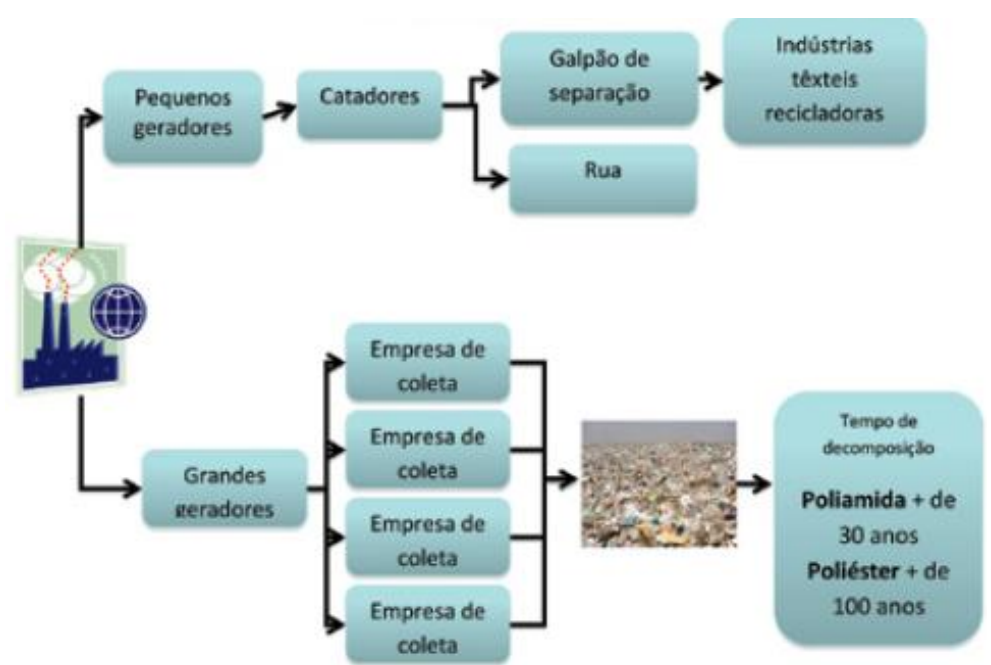

Figura 2.14. Fluxograma atual do destino dado aos refugos têxteis no bairro do Bom Retiro (CNI; ABIT, 2012) 
O Sinditêxtil/SP - Sindicato da Indústria de Fiação e Tecelagem, com o apoio da $A B I T$, instituiu na entidade um comitê para coordenar projetos relacionados à responsabilidade social na indústria têxtil paulista. O comitê é coordenado por membros diretores e colaboradores do Sinditêxtil/SP e de instituições parceiras, como o Sindicato das Indústrias de Vestuário do Estado de São Paulo - Sindivest, a Prefeitura Municipal de São Paulo, a Câmara dos Dirigentes Lojistas do Bom Retiro - CDL e instituições de ensino e desenvolvimento, como o Senai Têxtil de São Paulo e a Universidade Presbiteriana Mackenzie.

O projeto está fundamentado em quatro pilares (CNI; ABIT, 2012):

- responsabilidade ambiental;

- responsabilidade social;

- agregação de valor para a indústria têxtil e de confecção;

- Política Nacional dos Resíduos Sólidos (Lei n 12.305, de 02/08/2010).

Com este projeto, prevê-se que a destinação dos refugos têxteis do bairro seja o seguinte (Figura 2.15):

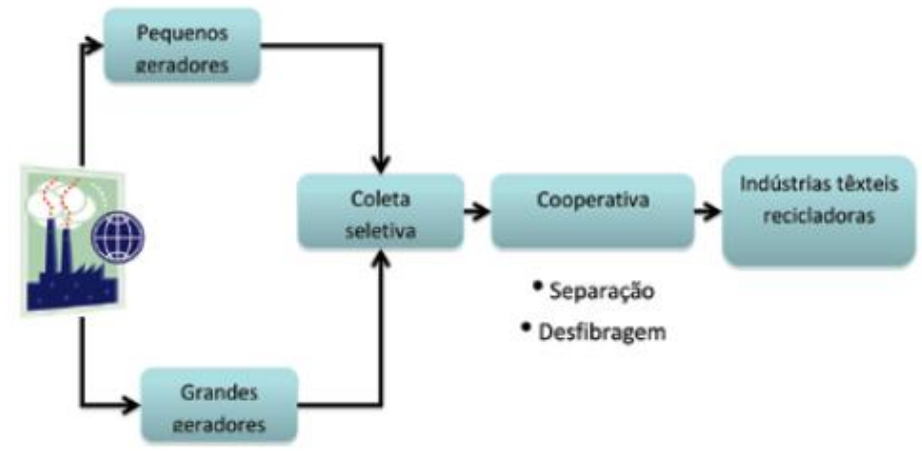

Figura 2.15. Fluxograma do destino dado aos refugos têxteis no bairro do Bom Retiro após a implantação do projeto (CNI; ABIT, 2012)

\subsubsection{A Reciclagem da Fibra de Algodão e Sua Posterior Fiação}

Sendo o Bom Retiro, notadamente, um dos grandes geradores de resíduos têxteis da cidade de São Paulo (LOGA, 2011) e baseando-se nos dados do IDEC (2005) sobre a produção da fibra de algodão no país - que representa $70 \%$ do total de fibras industrializadas, conclui-se que instituir a 
reciclagem deste tipo de fibra acarretaria grandes benefícios ao meio ambiente no que tange a sustentabilidade no setor de têxtil e moda.

A ideia de sustentabilidade se baseia no processo político-participativo que integra sustentabilidades econômica, ambiental, cultural, além das sustentabilidades coletivas e individuais, para o alcance e a manutenção da qualidade de vida, seja nos momentos de presença de recursos, ou quando há períodos de escassez, cujas perspectivas são a cooperação e a solidariedade entre os povos e as gerações (ECOTECE, 1999). Trigueiro (2005) afirma que:

Apenas 1,7 bilhão dos atuais 6,3 bilhões de pessoas que habitam 0 planeta têm hoje condições de consumir além das necessidades básicas. Ainda assim, a demanda por matéria-prima e energia cresce, precipitando o mundo na direção de um impasse civilizatório: ou a sociedade de consumo enfrenta o desafio da sustentabilidade ou teremos cada vez menos água doce e limpa, menos florestas, menos solos férteis, menos espaço para a monumental produção de lixo e outros efeitos colaterais desse modelo suicida de desenvolvimento.

A aquisição de $250 \mathrm{~g}$ de algodão em uma camiseta implica em 1,7 $\mathrm{g}$ de combustíveis fósseis, $450 \mathrm{~g}$ de refugos em aterros e na emissão de $4 \mathrm{~kg}$ de $\mathrm{CO}_{2}$ na atmosfera. Logo, o reuso e a reciclagem das fibras proporcionam benefícios ambientais e econômicos. A recuperação desses materiais têxteis (ALWOOD et al., 2006), seguindo os princípios da Produção+Limpa:

(i) Reduz a necessidade de espaço em aterro. Os têxteis apresentam problemas especiais no aterro sanitário como as fibras sintéticas, que demoram muito para se decompor, enquanto que as peças de lã se decompõem e produzem metano, que contribui para o aquecimento global;

(ii) Reduz a pressão sobre os recursos naturais;

(iii) Resultados satisfatórios no controle da poluição e na economia de energia; 
(iv) Menor gasto com matérias-primas.

Uma fibra reciclada evita muitos dos processos energéticos poluentes necessários para fazer tecidos de matérias-primas virgens, incluindo:

(i) Redução no consumo de energia durante o processamento, visto que essas fibras não precisam ser necessariamente tintas novamente;

(ii) Menor poluição dos efluentes, uma vez que as fibras já estão previamente beneficiadas;

(iii) Redução da demanda por corantes e agentes de fixação e dos problemas causados pelo seu uso e fabricação.

Contudo, a reciclagem do vestuário ou qualquer outro item têxtil não é simples. A sua complexidade começa na logística dos estágios implícitos nesse processo (BROEGA; CARVALHO; MORAES; 2011), como:

(i) Coleta e transporte;

(ii) Identificação e separação;

(iii) Desmontagem ou desfibração;

(iv) Lavagem ou limpeza;

(v) Pré-produção de matérias-primas secundárias.

Quase todos os países que desenvolvem políticas de reciclagem têxtil ou até mesmo de reutilização integram esses procedimentos, tanto em nível estatal quanto em nível privado, acarretando custos de mão de obra e respectiva transformação (BROEGA; CARVALHO; MORAES; 2011). 
Após a reciclagem da fibra de algodão (como resíduo pós-industrial ou pós-consumo), há o processo de fiação deste material remanufaturado. A fiação tem seu principal objetivo em transformar a matéria prima, fibras ou polímeros, fios e filamentos. Os fios são materiais constituídos de fibras, que possuem grande comprimento e forma aproximadamente cilíndrica, de pequeno diâmetro. Já os filamentos têm praticamente todas as características das fibras, diferindo apenas no comprimento. Os filamentos podem ter tamanho infinito, podendo ser opacos, semi opacos ou brilhantes (ALFIERI, 2012).

Tanto as fibras virgens de algodão quanto as recicladas passam pelos mesmos processos mecânicos de fiação, diferenciando-se em um aspecto: as fibras recicladas, que podem ser oriundas de aparas ou mesmo de artigos confeccionados - previamente separados por composição e cor, necessitam passar por um maquinário específico que as destrinche, uma vez que já estão consolidadas na forma de tecido. Após este processo de desfibragem, o fluxograma de produção segue o mesmo para ambos os casos (Figura 2.16).

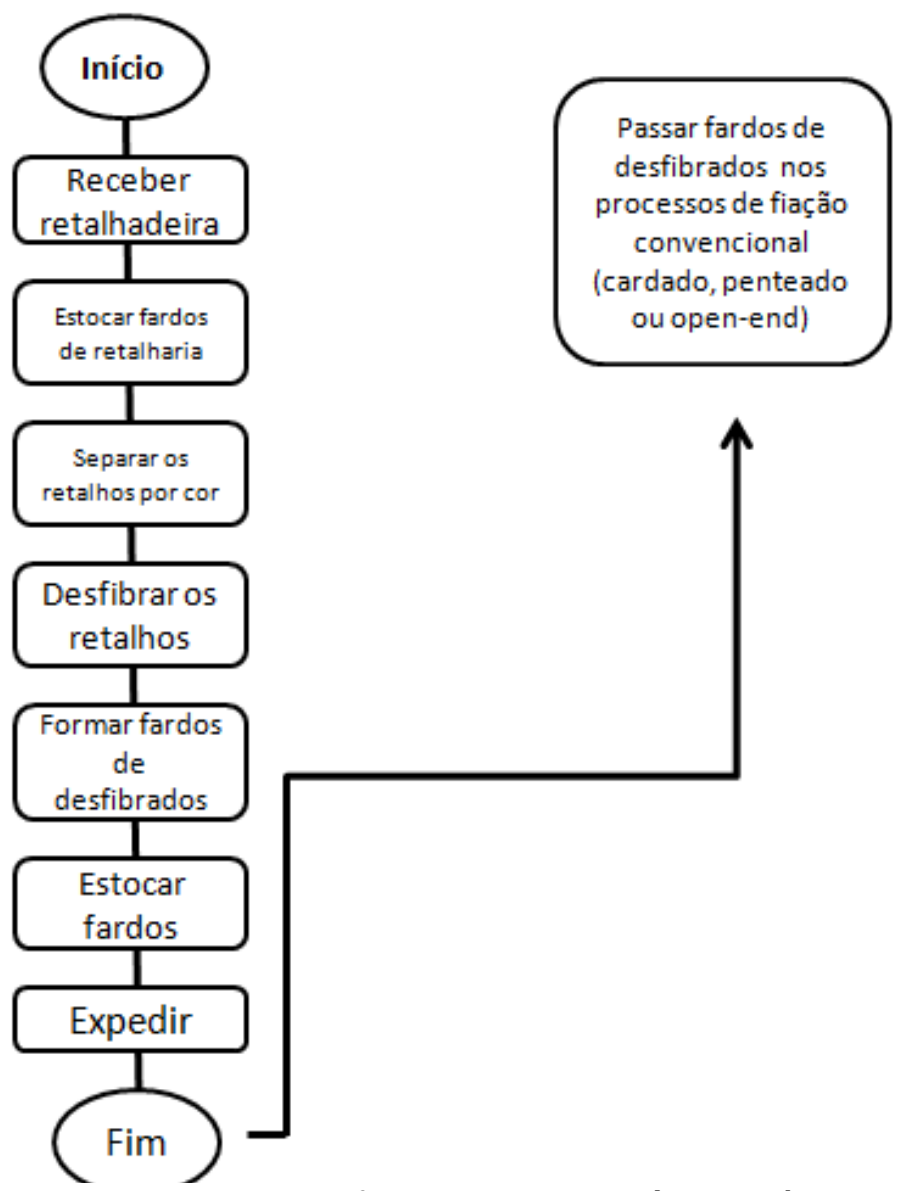

Figura 2.16. Fluxograma para desfibragem de resíduos têxteis: fase anterior a uma nova fiação (ilustração do autor, 24/11/2012) 
De acordo com Holtz (2007), nos diversos processos da indústria têxtil são gerados diferentes tipos de resíduos com diferentes composições químicas. Os resíduos de algodão são gerados na fiação e na tecelagem e equivalem aproximadamente a $8 \%$ do total do algodão processado sendo, até então, pouco explorados.

Os resíduos têxteis de fios, tecidos e aparas de confecção são processados e retornam à condição de fibras que resultam num comprimento aproximadamente $20 \%$ menor que a fibra original virgem utilizada no primeiro processo de industrialização, visto que muitas das fibras são cortadas pelos maquinários na linha de produção da reciclagem. Dependendo da utilização final da fibra, o processo de regeneração deverá ser mais ou menos intenso; portanto, produzirá uma fibra de maior ou menor qualidade final, o que determinará o processamento dos resíduos, podendo o resultado final ser muito próximo ao primeiro processo de manufatura da fibra (SBRT, 2007).

Há fibras regeneradas que poderão ser usadas sem mistura com fibras virgens ou em diversas misturas, dependendo do produto final a qual se destina. Outro detalhe bastante importante é determinar exatamente a composição da fibra reciclada, pois dependerá do perfeito conhecimento da composição original do resíduo do fio, tecido e apara. Deve-se também observar a questão da cor da fibra reciclada, pois poderá ser uma cor indefinida ou sofrer processos químicos de descoloração, alvejamento e/ou tingimento (SBRT, 2007) (Figura 2.17).

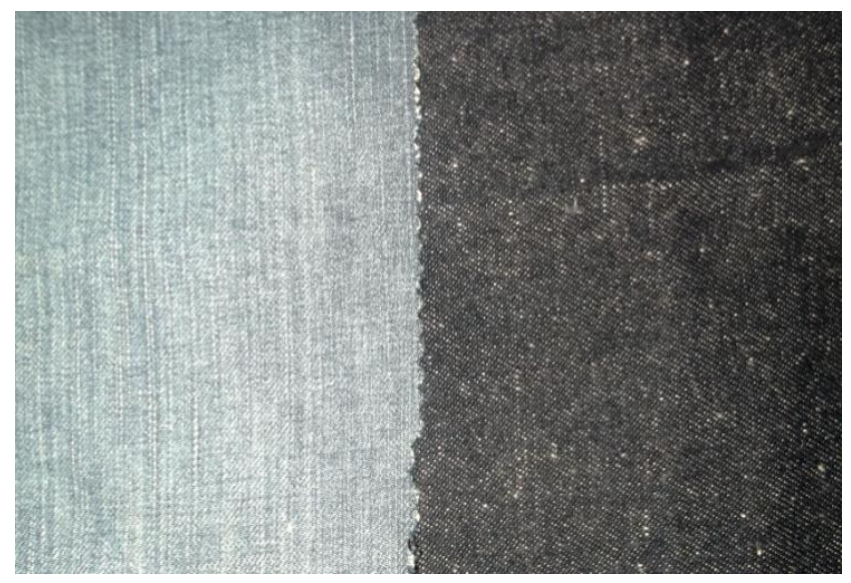

(a)

(b)

Figura 2.17. Aspecto visual de tecidos denim: (a) feito $100 \%$ de vibra de algodão virgem; (b) feito 100\% com fibra de algodão reciclada (Fotos do autor, 04/02/2012) 
As fases da fiação de fibras virgens de algodão são descritas a seguir (Figura 2.18) (PEREIRA, 2009):

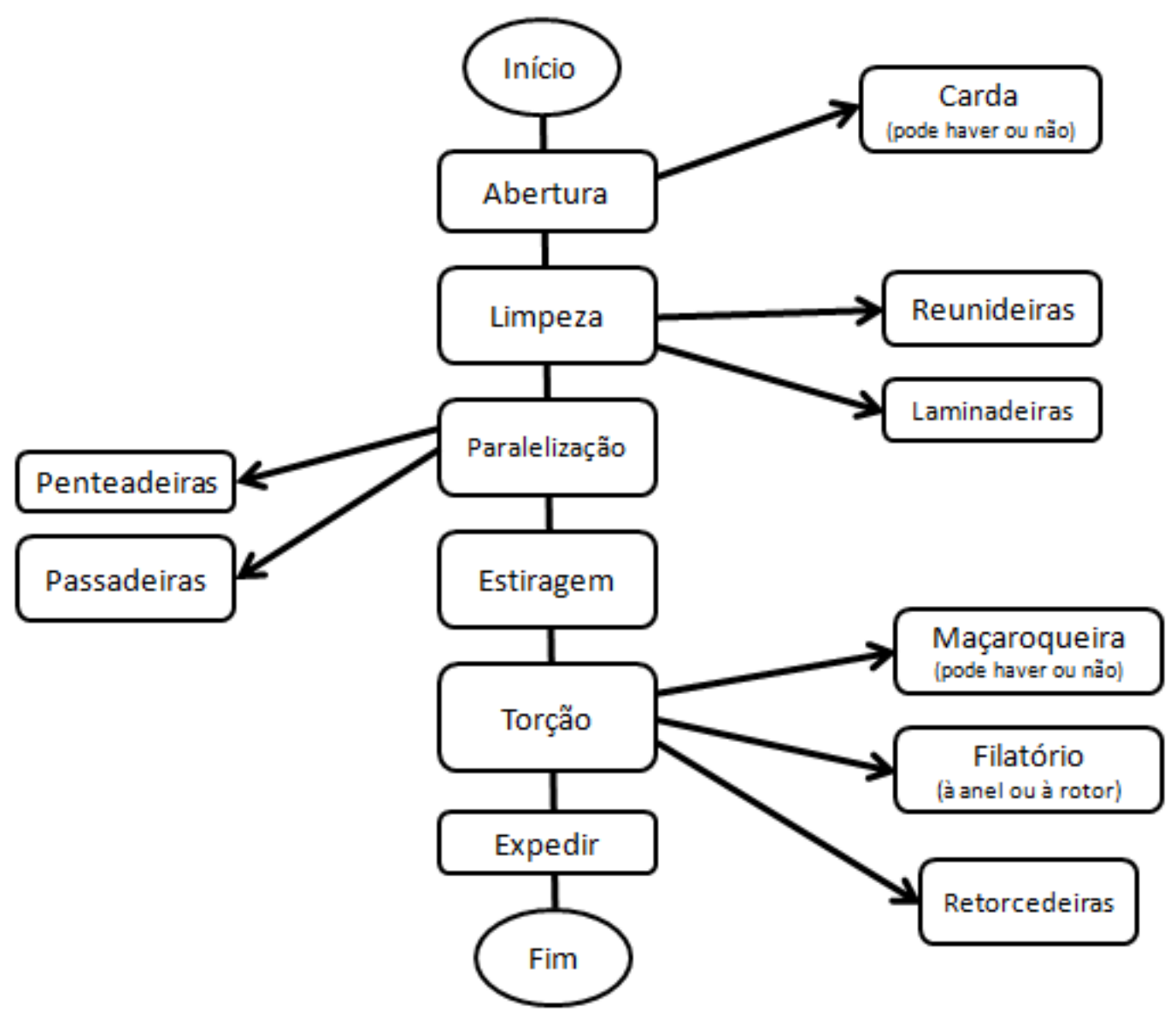

Figura 2.18. Fiação das fibras virgens de algodão (llustração do autor, 04/02/2012)

(i) Abertura: as fibras são separadas ao máximo através do batedor, que tem por objetivo abrir, limpar, misturar e uniformizar por unidade de comprimento a massa de fibras que vão constituir a manta;

(ii) Limpeza: elimina o máximo de impurezas que vem dos fardos das fibras naturais; transformam a manta numa fita, que passa pela reunideira para transformar as várias fitas num único rolo de manta compactado; por fim, esta manta compactada passa pela laminadeira, que reúne as várias mantas para produzir um único rolo de mantas; 
(iii) Paralelização: as fibras são escovadas e organizadas num único sentido; depois da laminadeira, o rolo de mantas passa pela penteadeira, onde as fibras curtas são removidas e elimina eventuais embaraços (os "neps"); as fibras chegam na passadeira, que uniformiza a fita de saída;

(iv) Estiragem: os feixes de fibras obtidos passam por cilindros que "espremem" as mantas, afinando-as, dando origem ao fio. Nesta fase é decidido o título do fio produzido;

(v) Torção: é a operação que dá às fibras paralelizadas um certo número de voltas em torno do eixo do fio que se quer obter. Tem início na maçaroqueira, passando pelo filatório onde termina o processo. Pode ser encaminhado à retorcedeira, que retorce dois ou mais fios singelos formando um único fio, mais resistente e uniforme. Os tipos de torção possíveis são em sentido horário (torção em "Z") ou sem sentido anti-horário (torção em "S").

Dentro da fiação, existe a possibilidade de produzir fios mais ou menos limpos, bem como fios mais finos ou grossos, dependendo do processo que se adota. Eles podem ser (PEREIRA, 2009):

(i) Fio Cardado: produz um fio mais irregular, com mais impurezas, menos resistentes e mais grossos. Passa pela máquina carda, que destrincha os fardos de algodão. Os exemplos de tecidos produzidos a partir desses fios são: a chita, a popeline, a lona, entre outros;

(ii) Fio Penteado: produz um fio mais regular, com menos impurezas, mais resistente e mais fino. É um processo mais demorado e mais caro por passar por mais maquinários como as penteadeiras. Os exemplos de tecidos são: a organdi, o tricoline, o voil, entre outros;

(iii) Fio Open-End: possui qualidades como maior afinidade com corantes e menor uniformidade. Seu toque é mais áspero, os fios são mais rebeldes devido ao excesso de torção, sua resistência é menor 
se comparado com um fio convencional. É um processo mais rápido e barato por não passar por máquinas como carda, laminadeira e a penteadeira. O tecido originado desse tipo de fio geralmente é o denim.

Qualquer tipo de tecido e de composição pode ser reciclado e fiado novamente, observando atentamente quais são as características físicoquímicas da matéria-prima e qual produto final se deseja obter. Por isso, a separação dos tecidos ou fios por composição e cor é feita previamente para um melhor resultado final. Caso haja a mistura entre matéria-prima natural e sintética, pode ocorrer a fundição das fibras químicas pela alta temperatura dos processos mecânicos, comprometendo o processo (PEREIRA, 2009).

No caso dos tecidos feitos $100 \%$ com fibras de algodão, faz-se necessário definir como são constituídos esses materiais têxteis com alto potencial reciclável. A contextura de um tecido refere-se ao tipo de entrelaçamento do mesmo (Figura 2.19), que pode ser classificado como (PEREIRA, 2009):

(i) Tecido plano, se constituído de trama e urdume se sobrepondo um ao outro;

(ii) Tecido de malha, que é caracterizado pelo entrelaçar dos fios têxteis, sendo esses sempre no mesmo sentido, ou todos na trama ou todos no urdume. O processo é realizado com a ajuda de agulhas e o modo fundamental de tecimento é tricô, onde há a formação de laçadas;

(iii) Nãotecido, caso seja uma estrutura plana, flexível e porosa, constituída de véu ou manta de fibras ou filamentos, orientados direcionalmente ou ao acaso, e consolidados por processo mecânico (fricção) e/ou químico (adesão) e/ou térmico (coesão) e combinações destes, conforme definição da norma NBR-13370. Ou seja, é um emaranhado de fios ou fibras unidos de maneira aleatória por meio de calor, substâncias químicas ou algum processo mecânico. 


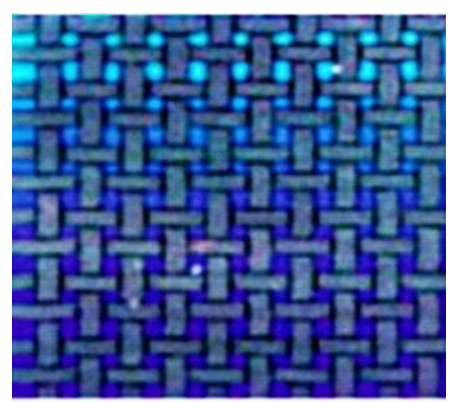

(a)

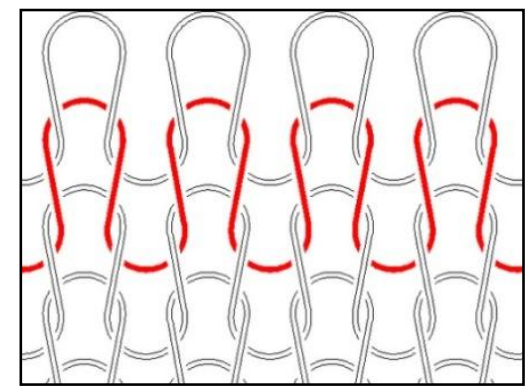

(b)

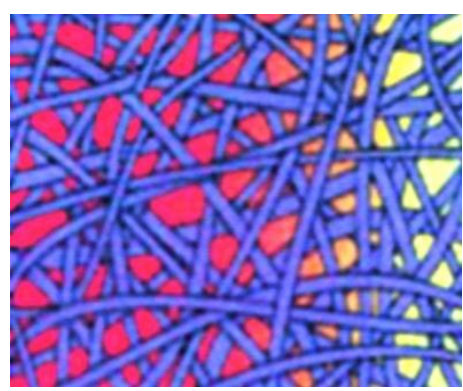

(c)

Figura 2.19. Tipos de tecidos que podem ser reciclados: (a) tecido plano; (b) tecido de malha; e (c) nãotecido (CATAGUAZES, 2012)

Qualquer tipo de material têxtil pode ser reciclado, embora, seja mais comum deparar-se com novos produtos têxteis em forma de nãotecido por ser tratar de um processo mais barato e que não exige separação dos retalhos por cor ou composição, geralmente utilizados como mantas para revestimento acústico, térmico, como enchimento de pelúcias, entre outros. Para produtos mais sofisticados, não é comum misturar fibras naturais e químicas, por exemplo, bem como tecidos planos e de malha no mesmo processo ou ainda de cores distintas (PEREIRA, 2009).

\subsubsection{Política Nacional de Resíduos Sólidos: um Avanço na Solução dos Problemas Ambientais}

O Brasil caracteriza-se por ser um país industrializado e com um grande potencial consumidor, principalmente de produtos ligados ao setor de têxtil e moda. Embora esteja atrasado em relação à reciclagem e reutilização de têxteis, há leis e iniciativas ecológicas sendo aprovadas a fim de minimizar os problemas ambientais.

As leis sobre resíduos sólidos começaram a serem propostas nos anos 1990, referentes sobre a destinação do que é gerado pelas atividades humanas. Em 1991, o projeto de Lei 203 discorreu sobre os resíduos derivados dos serviços de saúde, e em 1999 foi lançada a proposição Conama 259 das Diretrizes Técnicas para a Gestão de Resíduos Sólidos, realizado pelo Conselho Nacional do Meio Ambiente. O relatório foi aprovado em 2006, sendo finalizado e enviado à Casa Civil em 2007. 
Em 2001, a Câmara dos Deputados criou a Comissão Especial de Política Nacional de Resíduos Sólidos, apreciando a Lei 203/91, para instituir uma política global, mas foi extinta antes de cumprir seus objetivos. Ainda nesse ano, houve uma organização político-social dos catadores de materiais recicláveis. No ano de 2003, a discussão de resíduos sólidos também incluiu o tema de responsabilização dos geradores de resíduos sólidos, assim como a regulamentação da profissão de catador. O então Presidente Luís Inácio Lula da Silva, nesse ano, criou um grupo de trabalho que resultou no Programa Resíduos Sólidos Urbanos.

$O$ ano seguinte foi marcado pelo intercâmbio interministerial sobre os resíduos sólidos urbanos e o Conama realizou um seminário para formulação de nova proposta de lei, em substituição à Conama 259. O ano de 2005 confluiu os trabalhos realizados até então no anteprojeto de lei de "Política Nacional de Resíduos Sólidos", também com participações da sociedade civil e de grupos empresariais.

Em 2010, o projeto substitutivo foi aprovado (Lei 12.305 de 02/08/2010), fazendo com que o país agora tenha como regular as questões relativas aos resíduos sólidos. O lixo passa a ser separado entre: resíduos, que tem potencial de vir a ser reutilizado, através do reaproveitamento ou reciclagem; e rejeito, do qual não se consegue mais reaproveitar ou reciclar. Seu conteúdo compreende desde conceituações sobre os resíduos sólidos, os instrumentos de interferência legal, sua gestão, responsabilidades da sociedade e outros temas que permitem a intervenção na questão de resíduos sólidos (BRASIL, 2011).

O Ministério do Meio Ambiente apontou como objetivo deste projeto a não-geração, redução, reutilização e tratamento de resíduos sólidos, bem como destinação final ambientalmente adequada dos rejeitos. Apontou também propostas para a redução do uso dos recursos naturais (água e energia, por exemplo) no processo de produção de novos produtos, a intensificação de ações de educação ambiental, o aumento da reciclagem no país, a promoção da inclusão social e a geração de emprego e renda de catadores de materiais recicláveis (BRASIL, 2011).

Isto será feito a partir da responsabilidade coletiva pela geração e manutenção dos resíduos sólidos na sociedade, inserindo instrumentos que 
possibilitem a redução de uso de recursos e de disposição destes resíduos através da mudança de consciência trazida pela educação ambiental e reaproveitamento e reciclagem dos resíduos. Exigirá uma ação conjunta da sociedade civil, governo e empresas, assim como uma articulação intermunicipal já que, muitas vezes, a questão dos resíduos sólidos é tratada em conjunto pelos municípios.

Ainda é importante para a realização do que propõe a PNRS (Política Nacional de Resíduos Sólidos) a instituições de planos para se gerenciar os resíduos sólidos, assim como se levantar e declarar o quanto é gerado, responsabilização compartilhada pelos produtos, incentivo às Cooperativas, fiscalização ambiental e desenvolvimento de conhecimento técnico-científico proveniente de todos os setores da sociedade.

Assim, espera-se que os resíduos produzidos, entre os quais resíduos têxteis, sejam melhor geridos pelas empresas que os produziram e fiscalizados pelos órgãos competentes.

\subsection{Materiais e Formas no Reuso e Reciclagem de Têxteis}

\subsubsection{Design de Moda e Eco Design de Moda}

Bersen (1995) classifica o design como algo capaz de traduzir um propósito em uma forma física ou ferramenta. Logo, o design deve começar com a definição de um propósito e avança através de uma série de questões e respostas para se achar uma solução. Atualmente, o design está comprometido com a concepção e o planejamento de objetos, produção em escala nas sociedades industriais, demanda do mercado e com a capacidade produtiva do estabelecimento industrial (BEZERRA, 2004).

Segundo Rech (2004), produto de moda é qualquer elemento ou serviço que conjugue as propriedades de criação (design e tendências), qualidade (conceitual e física), usabilidade, aparência e preço, a partir das vontades e anseios do segmento de mercado ao qual se destina o produto.

A indústria de confecções do vestuário e de moda é a principal produtora de bens finais do complexo têxtil e o seu produto possui um ciclo de vida 
comercial curto. As confecções geram desperdícios significativos, que é transformado em aparas, retalhos e peças rejeitadas. Denominam-se resíduos os restos ou as sobras provenientes de um processo produtivo, e que são considerados como inúteis, indesejáveis ou descartáveis (MILAN; VITTORAZZI; REIS, 2010).

O design sustentável ou eco design pode ser definido como uma metodologia que tem como objetivo minimizar o impacto ambiental de um produto da concepção ao descarte. Dessa forma, vai além de mudanças localizadas em determinadas fases do ciclo de vida (como a substituição de uma matéria prima na fase da pré-produção, ou a utilização de embalagens reutilizáveis na fase de distribuição, por exemplo), e deve agir sobre o ciclo de vida do produto como um todo (MARTINS; SAMPAIO, 2006).

Produtos que incorporam parâmetros ambientais estão inseridos no campo do design sustentável e são desenvolvidos tendo em vista a redução de matéria-prima, recursos, água, impactos e o aproveitamento de resíduos, orientando-se desde a obtenção da matéria-prima, o processamento até seu descarte final.

Para Manzini e Vezzoli (2008), os limites ambientais são testemunhos de que já não é possível conceber qualquer atividade de design sem confrontá-la com o conjunto das relações que, durante o seu ciclo de vida, o produto vai ter no meio ambiente. Deve-se levar em conta que um artefato provoca impactos ambientais para ser produzido, distribuído, utilizado e eliminado/descartado.

Um produto de moda é de grande impacto ambiental, do momento da sua concepção ao momento de seu descarte. Dessa forma, uma das maneiras de se reduzir o impacto ambiental seria repensar toda sua conduta projetual e produtiva inserindo nos conceitos do design sustentável, minimizando assim os inputs e outputs durante o ciclo de vida do produto através do eco-design (MARTINS; SAMPAIO, 2006). O caráter sustentável deve ser levado em conta desde o pré-projeto até o processo produtivo, gerando mudanças tecnológicas e visando uma redução do impacto ambiental (MANZINI; VEZZOLI, 2008).

Para Papanek (1985), o principal problema com as escolas de design é o fato de ensinarem projeto com pouco ou nenhum foco sobre as variáveis ambientais, ecológicas, sociais, econômicas e políticas, enfatizando que tais variáveis devem ter maior peso diante da metodologia e da maneira de pensar 
o projeto. Assim, com o avanço da industrialização e da mecanização e a consequente divisão do trabalho e fragmentação dos conhecimentos tradicionais, inviabiliza-se o fluxo de informações sobre a diversidade biológica, a cultura e tecnologia desses grupos, fundamentais para a compreensão e elaboração de projetos sustentáveis e que respeitem todas as etapas do "Ciclo de Vida do Sistema-Produto" (MANZINI; VEZZOLI; 2002).

A busca por novos materiais por parte dos estabelecimentos industriais incrementa ainda mais os impactos, interferindo nos ecossistemas, reduzindo a biodiversidade biológica e levando à extinção inúmeras espécies da fauna e flora, assim como diversas comunidades tradicionais que subsistem dos recursos obtidos na natureza (FINKIELSZTEJN, 2006).

Broega, Carvalho e Moraes (2011) sugerem como poderia ser a metodologia de eco-design no Ciclo da Moda: através de um campo de análise abrangente, que englobe todos os estágios por onde passa o vestuário, pretende-se integrar possibilidades viáveis a partir do seu despejo (Figura 2.20). Para tal seria necessária também a intervenção de organismos públicos e privados que ajudem no correto plano de recolha, gestão e distribuição do vestuário indesejado, que seguidamente será transformado sob processos de "reciclagens parciais ou totais".

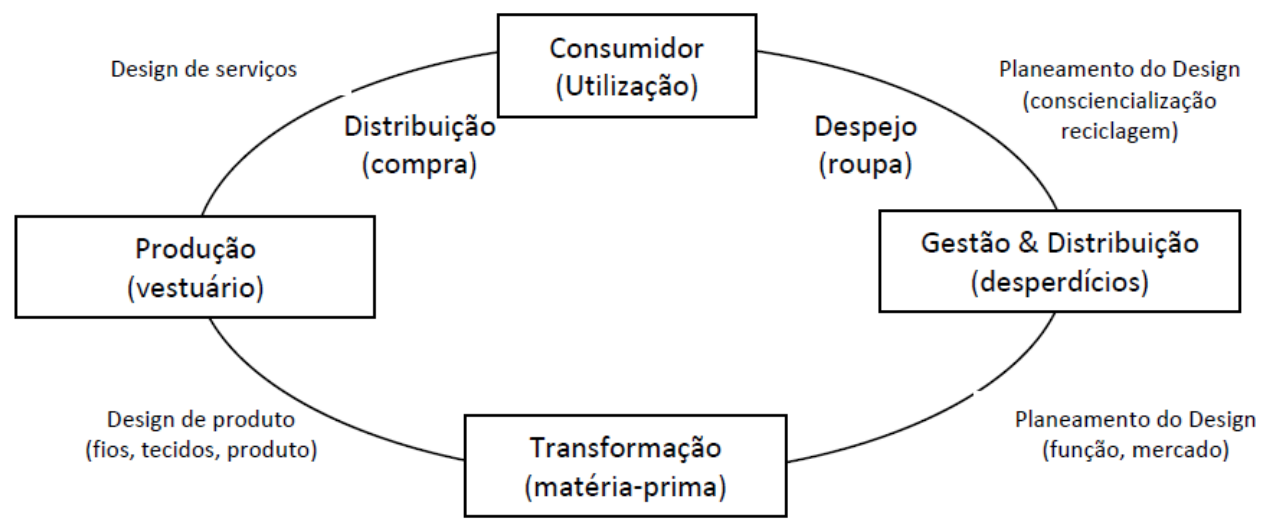

Figura 2.20. Ciclo de análise Design Sustentável para a maximização da reutilização e reciclagem de vestuário descartado (BROEGA; CARVALHO; MORAES, 2011) 
Nos Estados Unidos, no estado de Maryland, existe uma Organização Não-Governamental sem fins lucrativos, denominada Conselho para a Reciclagem de Produtos Têxteis (CRT), que visa educar o público sobre a importância da reciclagem de têxteis em geral em seu novo site. Com o slogan "Wear. Donate. Recycle" (vestir, doar e reciclar), o conselho pretende zerar os resíduos têxteis do pós-consumo até 2037 (ECOFASHION MAG, 2012).

Segundo o site Ecofashion Mag (2012):

Nos Estados Unidos, em média, as pessoas descartam por ano, o equivalente a 70 libras (31,75 quilos) em artigos de vestuário, calçados e têxteis, que saem das suas casas e seguem diretamente para os aterros. Segundo estudos realizados pelo CTR, hoje, os resíduos têxteis ocupam cerca de $5 \%$ dos aterros do país. Apenas $15 \%$ dos resíduos gerados pela população têm sido reciclados, o que equivale a 3,8 bilhões de quilos reciclados por ano. Os $85 \%$ restantes de resíduos têxteis são descartados nos aterros. Isto significa que a maior parte dos 25 bilhões de quilos de roupas, têxteis e calçados, que são produzidas anualmente nos Estados Unidos, estão contaminando o meio ambiente.

Fundado na Inglaterra, o site Recycled Products (http://www.recycledproducts.org.uk) traz um compilado de produtos ecológicos: nele, há um campo de busca para que o usuário realize a pesquisa sobre qual segmento preferir, como mobília, decoração, acessórios para banheiro e de higiene, entre outros. É possível também realizar a busca no segmento de vestuário e acessórios e descobrir quais marcas utilizam materiais reciclados em seus produtos e a porcentagem de matéria-prima reciclada neles (Figura 2.21). 


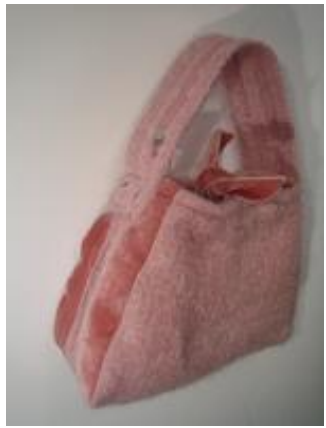

(a)

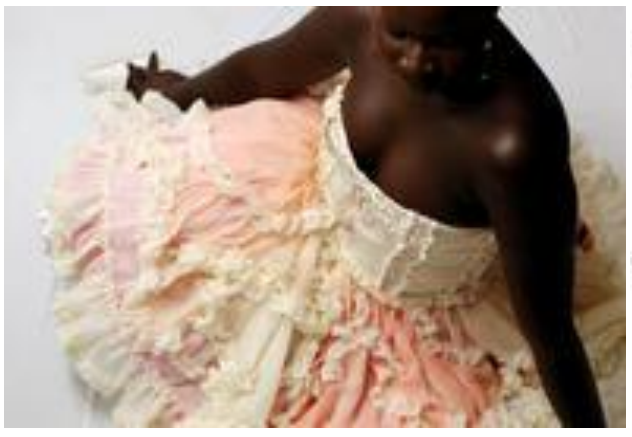

(b)

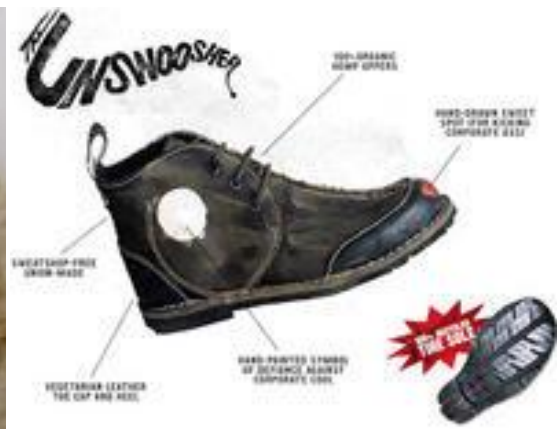

(c)

Figura 2.21. Exemplos de produtos de moda ecologicamente corretos: (a) Bolsa artesanal da marca The Green Door, feita 99\% de material reciclado (RECYCLED PRODUCTS, 2012); (b) Vestido da marca Leftover feito 99\% de material reciclado (RECYCLED PRODUCTS, 2012); (c) Bota unissex da marca Veganline feita $30 \%$ de material reciclado (RECYCLED PRODUCTS, 2012)

O estilista inglês Gary Harvey, que participa da semana de moda de Londres, também aderiu ao reuso de peças de roupas para comprar outras peças, tendo destaque para os artigos em denim (Figura 2.22).

No Brasil, algumas marcas e fabricantes de jeanswear, como a TNG e Tavex Co., também vem investindo na área de reciclagem e reutilização, oferecendo ao mercado produtos que possuem valores ecológicos e estéticos agregados (Figura 2.23). 


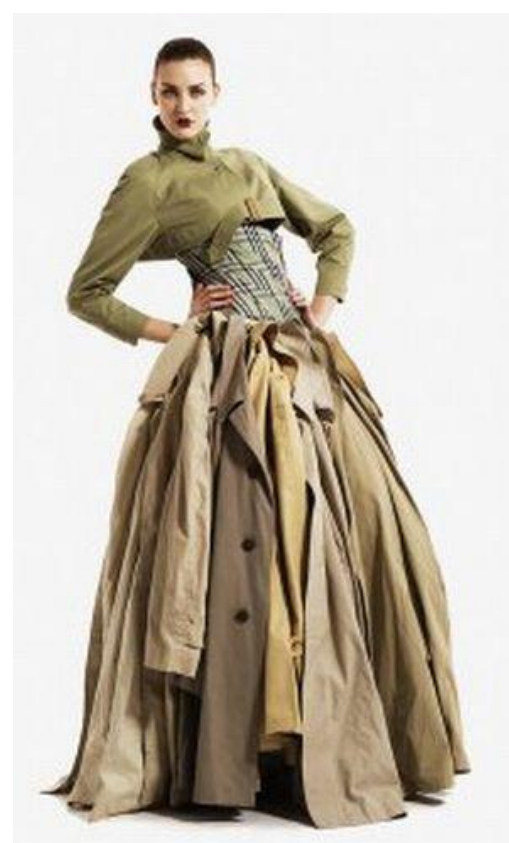

(a)

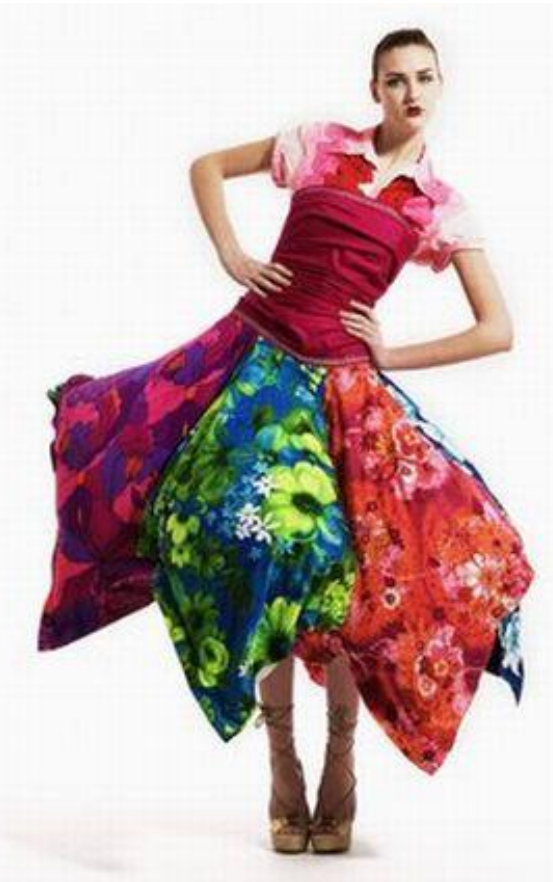

(c)

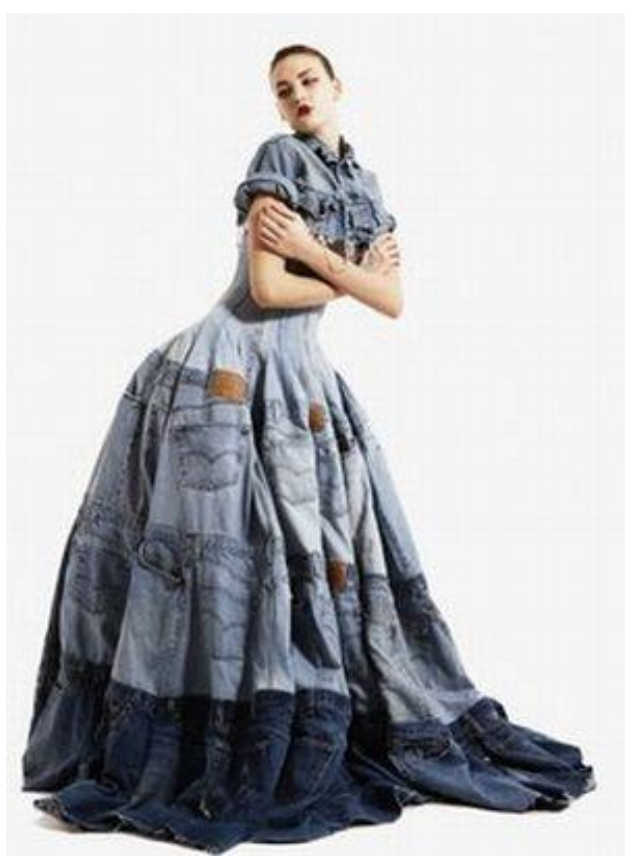

(b)

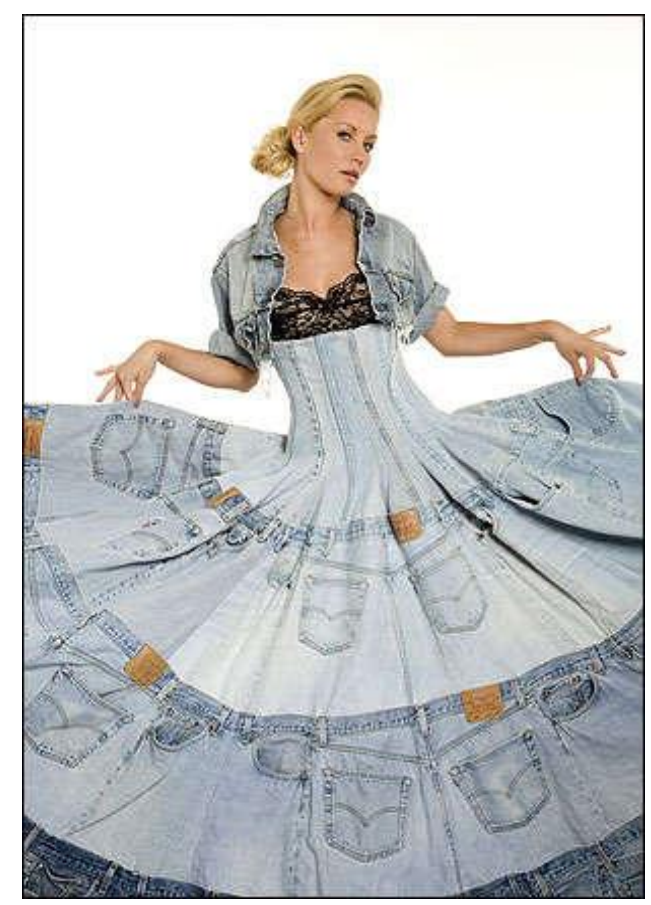

(d)

Figura 2.22. Coleção do estilista Gary Harvey: (a) vestido feito com casacos reutilizados (SETOR RECICLAGEM, 2012); (b) vestido feito com calças jeans reutilizadas (SETOR RECICLAGEM, 2012); (c) vestido feito com capas de almofadas reutilizadas (SETOR RECICLAGEM, 2012); (d) vestido feito com calças jeans reutilizadas (SETOR RECICLAGEM, 2012) 


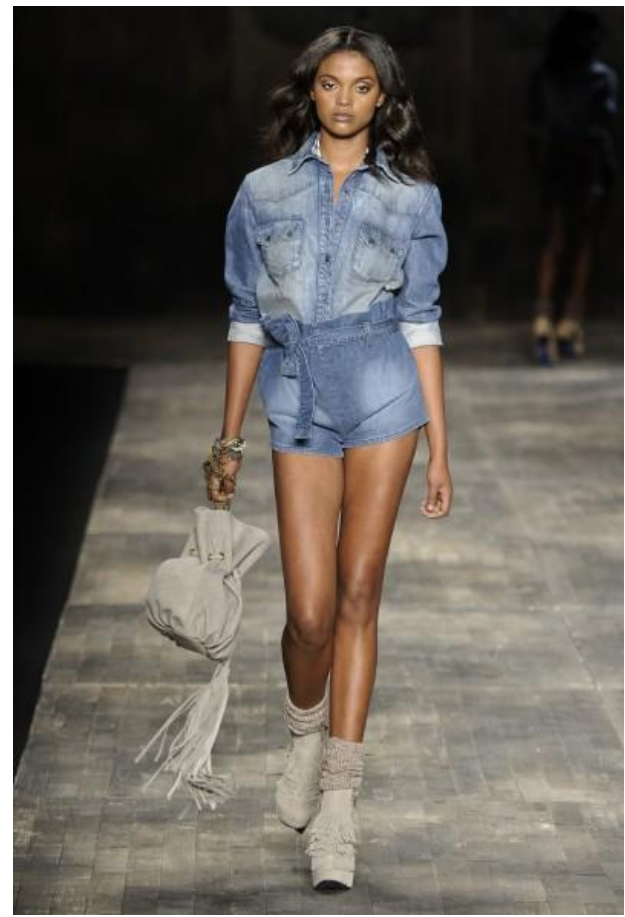

(a)

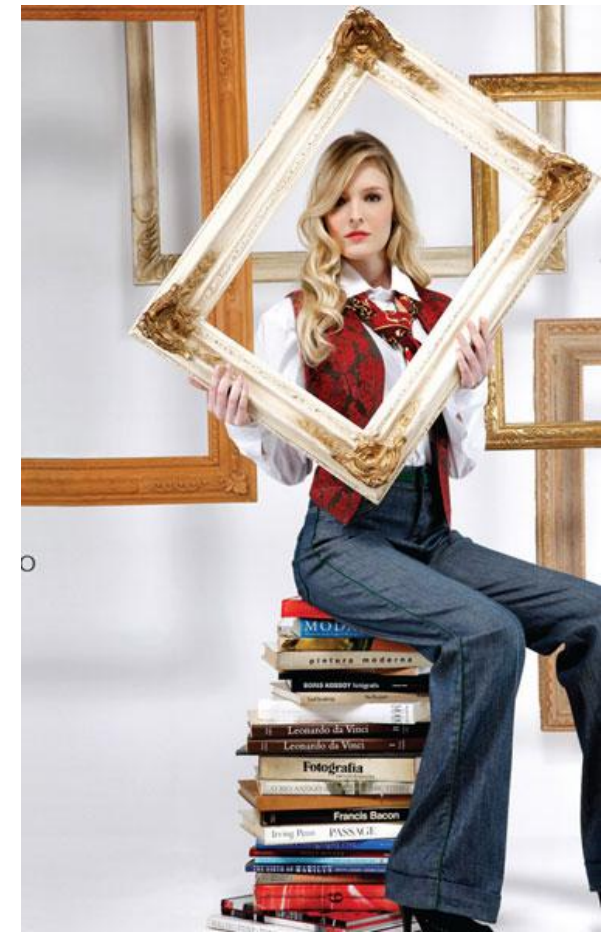

(b)

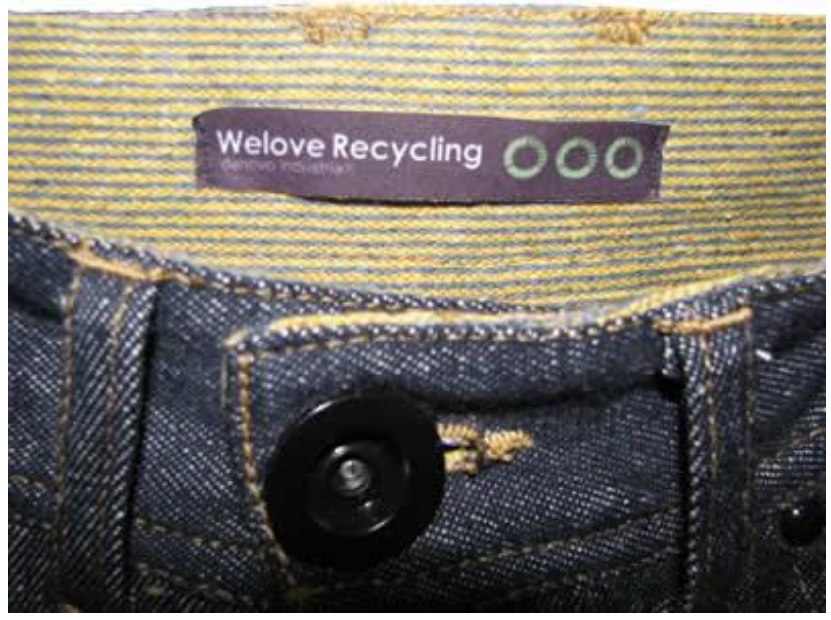

(c)

Figura 2.23. Jeanswear ecologicamente corretos: (a) desfile da marca TNG na São Paulo Fashion Week - Inverno 2012, onde mostrou peças em denim 100\% recicladas, feitas de garrafas $\mathrm{PET}$ e de resíduos de indústrias têxteis (SP FASHION WEEK, 2012); (b) Bio Denim $\AA$ da marca Tavex Co., feito com fios reciclados (MODA ECOLÓGICA, 2012); (c) a tecelagem Denovo acaba de lançar uma produção-piloto do denim reciclado feito de garrafas PET (MODA ECOLÓGICA, 2012) 
No segmento de acessórios de moda, também é possível deparar-se com muitos produtos feitos de modo ecológico, reutilizando outros artigos têxteis. No Brasil, exemplos são apresentados na Figura 2.24.

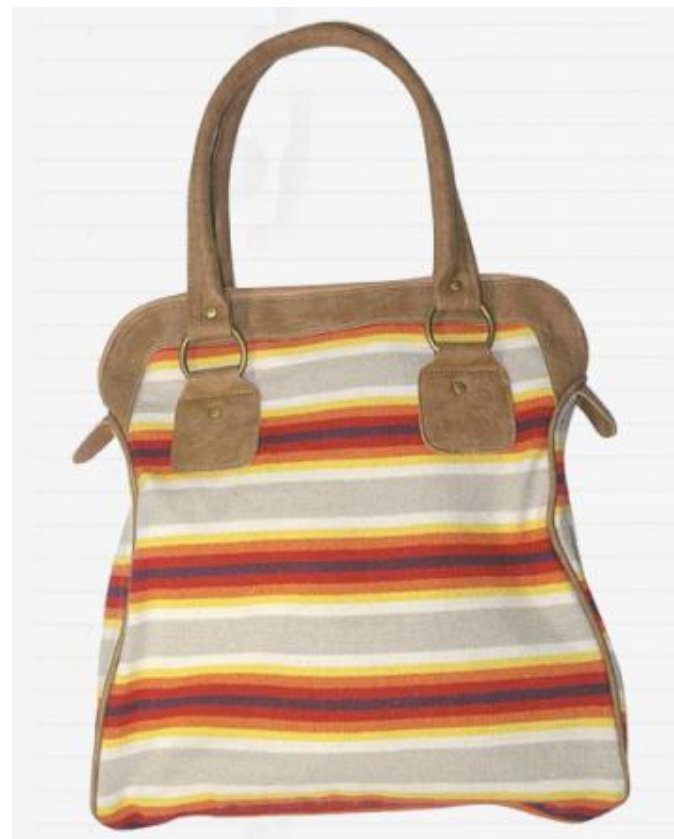

(a)

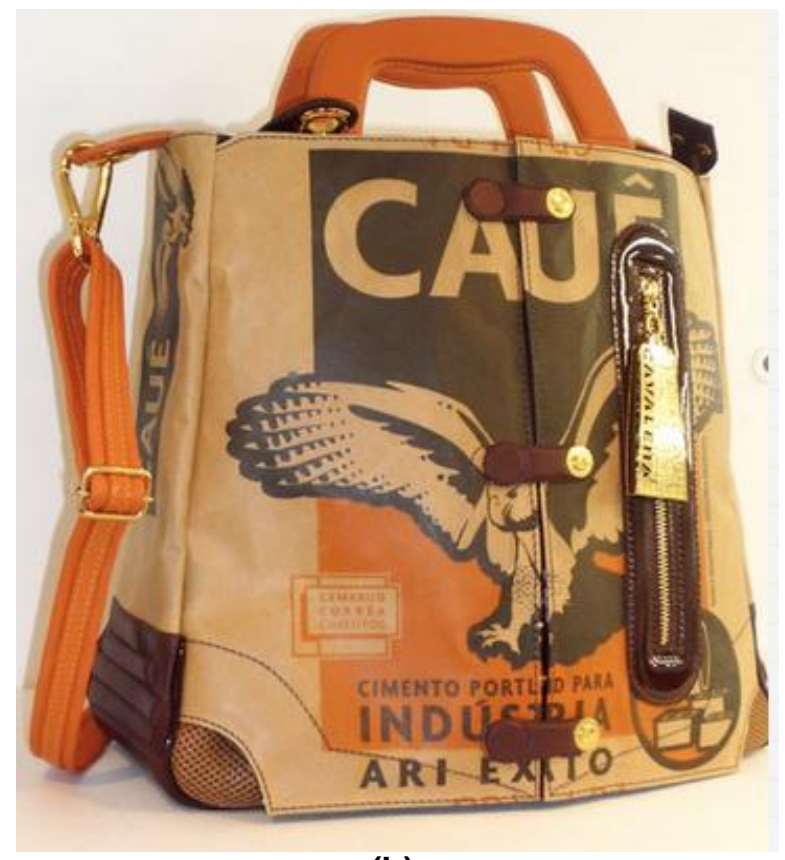

(b)

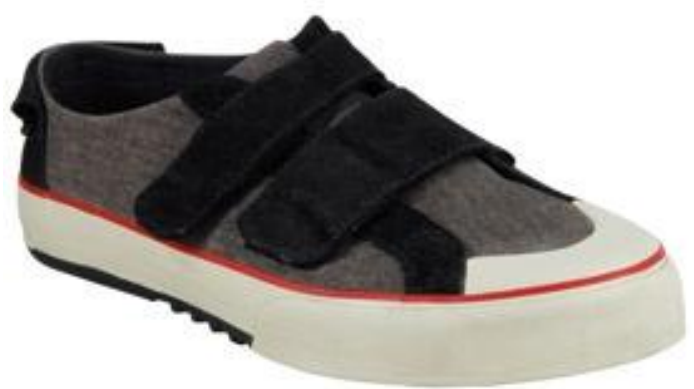

(c)

Figura 2.24. Acessórios de moda ecologicamente corretos de marcas brasileiras: (a) bolsa feita com tecido reciclado da marca Lucy in the Sky (PENCE FUNDAMENTAL, 2012); (b) bolsa da marca Cavalera feita com sacos de cimento reutilizados (PENCE FUNDAMENTAL, 2012); (c) tênis da marca Redley feito com o tecido ECO, composto de garrafas PET recicladas e algodão (PENCE FUNDAMENTAL, 2012)

Marcas estrangeiras também possuem acessórios de moda feitos com refugos têxteis ou produzidos de um modo menos impactante ao meio ambiente, como apresentado na Figura 2.25. 


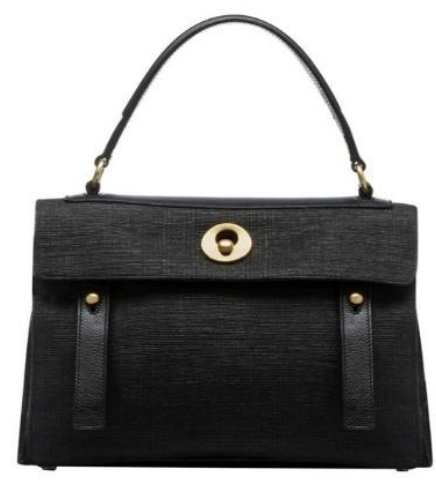

(a)

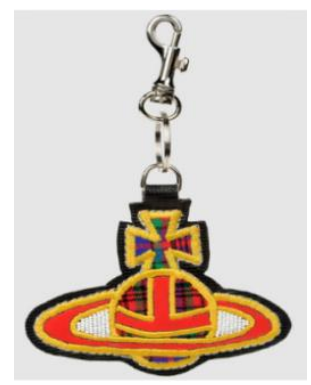

(c)

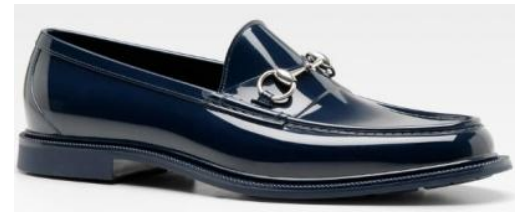

(e)

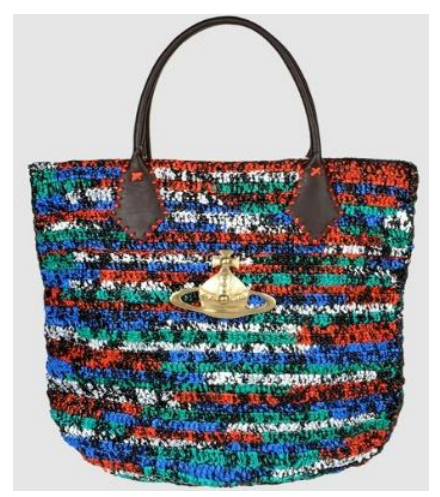

(b)

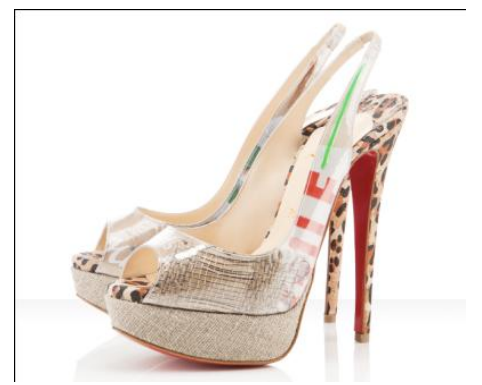

(d)

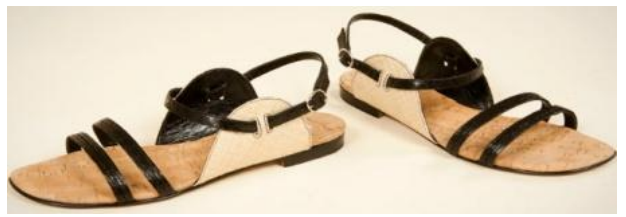

(f)

Figura 2.25. Acessórios de moda ecologicamente corretos de marcas estrangeiras: (a) bolsa "Muse Two Artisanal Recycled" da marca Yves Saint Laurent em homenagem a popular casa de moda Muse Two Design, de produção limitada; o material utilizado é plástico reciclado e algodão produzido pelo justo comércio (ECOFASHION MAG, 2012); (b) bolsa da marca Yoox, desenvolvido pela estilista Viviene Westwood, feita $100 \%$ de material reciclado (ECOFASHION MAG, 2012); (c) chaveiro da marca Yoox, desenvolvido pela estilista Viviene Westwood, feito $100 \%$ de material reciclado (ECOFASHION MAG, 2012); (d) sapato "Eco Trash" da marca Christian Louboutin: feito de cortiça, PVC e juta, materiais recicláveis e biodegradáveis (ECOFASHION MAG, 2012); (e) sapato masculino da marca Gucci, feita de couro vegetal; a marca patenteou a borracha "rubber moc", que passa por processos que não agridem o meio ambiente (ECOFASHION MAG, 2012); (f) em parceria com a designer Marcia Patmos, a marca de luxo Manolo Blanik, acaba de lançar uma coleção totalmente eco-friendly; as sandálias são produzidas com pele de tilápia, que seria descartada pela indústria alimentícia (ECOFASHION MAG, 2012)

$\mathrm{Na}$ área de decoração, é possível encontrar exemplos de produtos feitos com material têxtil reciclado ou de reuso. É importante enfatizar que as aparas 
têxteis podem ser reutilizadas de diversas formas, compondo produtos ecologicamente corretos e de grande apelo visual. Na Figura 2.6 encontram-se alguns exemplos de móveis feitos com restos de tecidos, alguns deles expostos em salões de design de grande renome internacional.

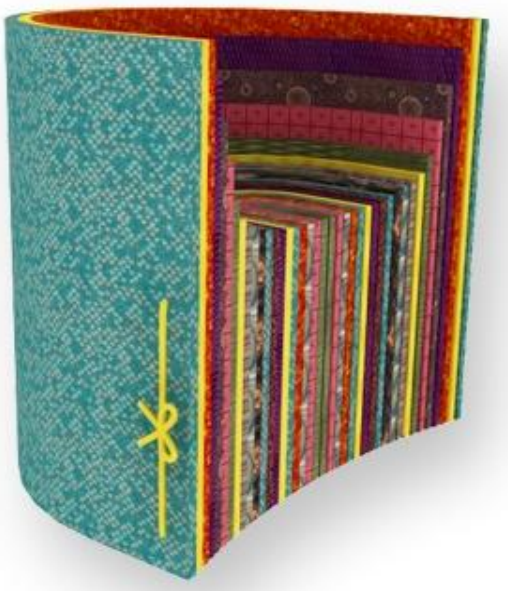

(a)

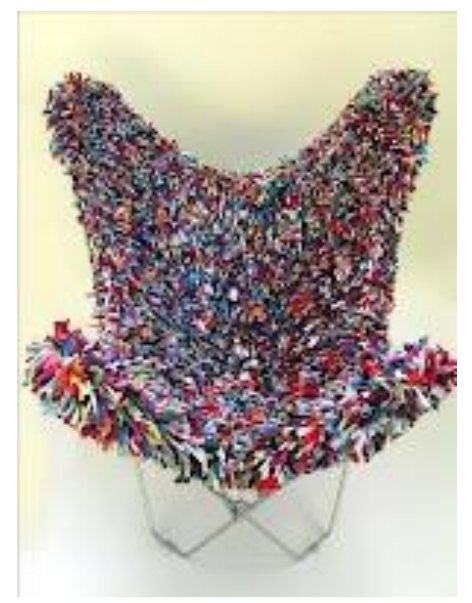

(c)

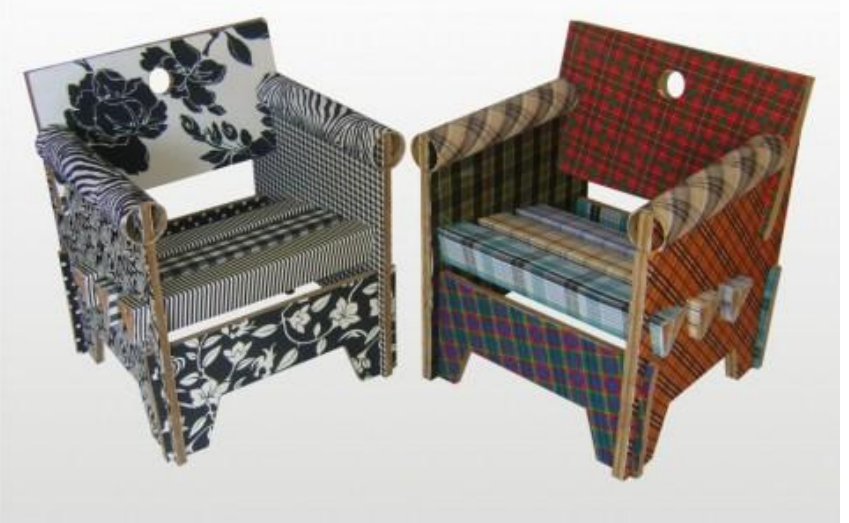

(b)

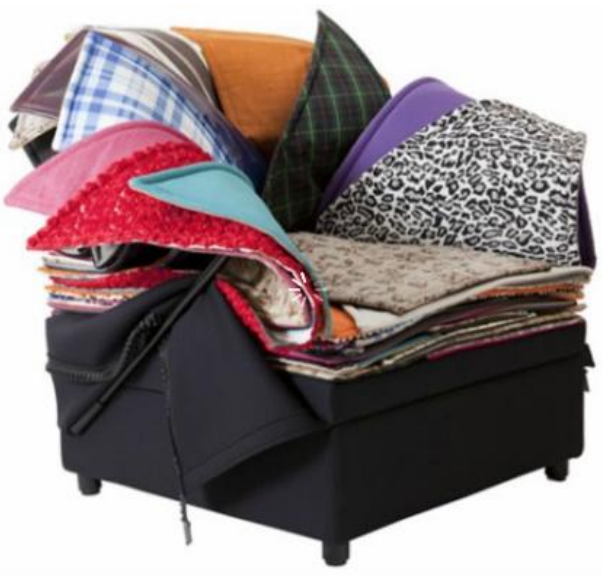

(d)

Figura 2.26. Design de móveis: (a) poltrona "Rug'n'Roll", feita a partir da cobertura tapetes de tamanhos diferentes um em cima do outro e mantidos juntos com duas cordas (ECOFASHION MAG, 2012); (b) poltronas do designer alagoano Ronaldo Edson da Silva, confeccionados com matéria-prima proveniente do lixo (papelão) e tecidos coletados em ateliês e adquiridos em lojas populares de Maceió (ECOFASHION MAG, 2012); (c) poltrona Butterfly da marca Reciclanto, revestida com retalhos (RECICLANTO, 2012); (d) poltrona Carnavale, apresentada na 14 $4^{a}$ edição do Salão Satélite - espaço ligado ao Salão Internacional do Móvel em Milão, feita pelos designers brasileiros Pedro Franco e Sérgio Matos (ECOFASHION MAG, 2012) 
Ainda, na Figura 2.7, alguns exemplos de reutilização de retalhos de tecido da empresa Reciclanto, localizada em Florianópolis. Os objetos de design e decoração foram expostos na $19^{\circ}$ edição do Craft Design, no Terraço Daslu, em São Paulo:

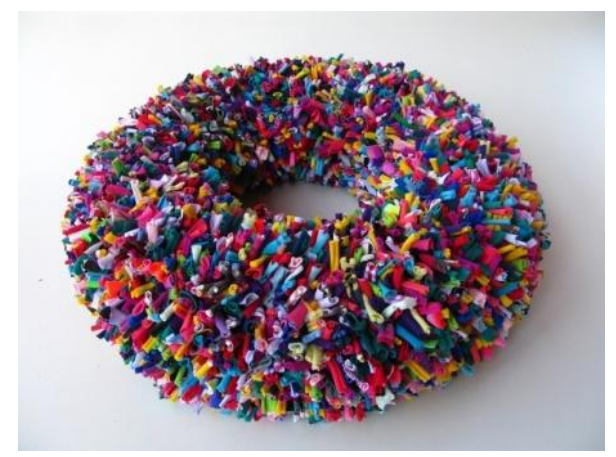

(a)

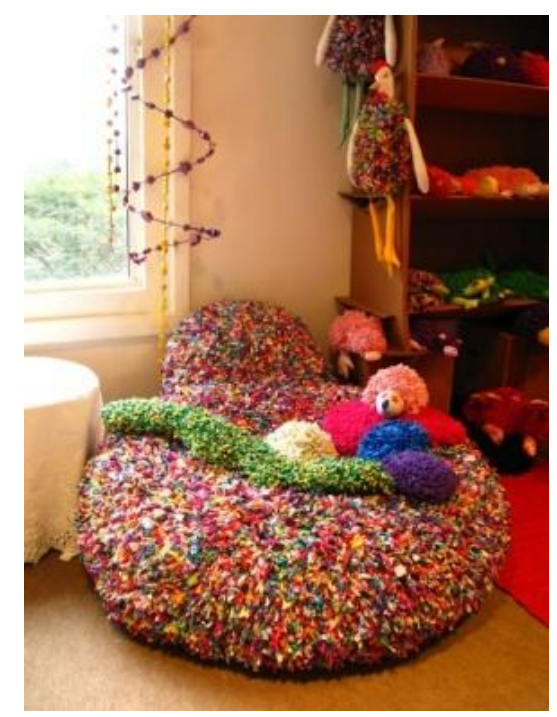

(c)

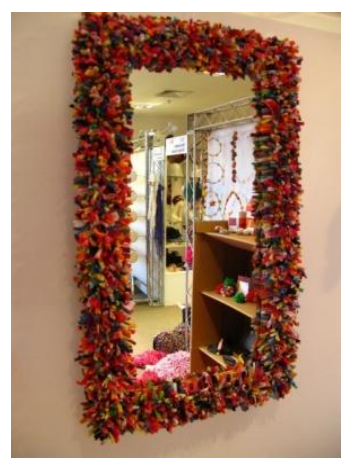

(b)

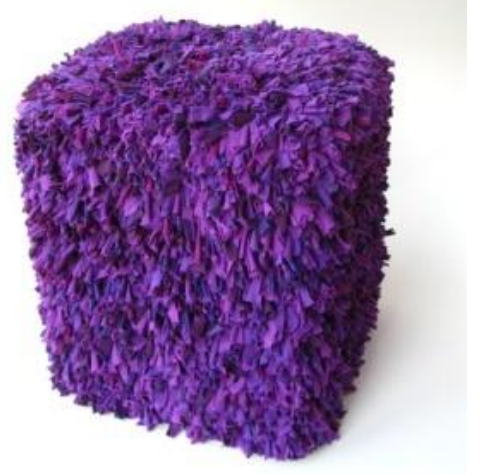

(d)

Figura 2.27. Modos de aplicação dos retalhos na decoração: (a) almofada inflável revistada com aparas (RECICLANTO, 2012); (b) moldura de espelho com tecidos (RECILANTO, 2012); (c) puff encapado com retalhos (RECILANTO, 2012); (d) poltrona revestida com refugos têxteis (RECICLANTO, 2012)

Com tantos exemplos de reciclagem e reutilização dos artigos têxteis, tanto no segmento de moda quanto no de decoração, é possível afirmar que tal prática vem se tornando recorrente e aplicada por diversas empresas. Uma das sugestões dadas em relação ao destino dos refugos têxteis seria a produção 
de compósitos para uso na indústria da moda e do design, detalhada nos próximos capítulos.

\subsubsection{Introdução aos Materiais Compósitos}

As possibilidades vistas como eficientes e corretas para a diminuição do lixo têxtil em aterros sanitários são:

i) reinserir as sobras dos processos industriais (fiação, tecelagem, malharia) em outros processos subsequentes, a fim de minimizar as sobras/desperdícios ao máximo, aplicando conceitos da Produção+Limpa;

ii) dedicar-se, exclusivamente, à reciclagem de têxteis, utilizando este material para produzir outros tipos de produtos, como mantas e nãotecidos.

Outra possibilidade correta de destinação dos resíduos têxteis - foco central deste trabalho, é a utilização deste material advindo das sobras industriais e/ou do descarte doméstico como reforço em compósitos de matrizes termorrígidas, que seriam destinados aos segmentos de moda ou a outros setores do design.

Materiais compósitos são aqueles que possuem pelo menos dois componentes ou duas fases, com propriedades físicas e químicas nitidamente distintas em sua composição. Separadamente, os constituintes do compósito mantém suas características, porém quando misturados, formam um composto com propriedades impossíveis de se obter com apenas um deles. As propriedades dos compósitos podem ser consideradas como uma combinação entre as propriedades da matriz, das fibras e das interfaces entre as fibras e matriz (CARVALHO, 2005).

Alguns exemplos são metais e polímeros, metais e cerâmicas, polímeros e cerâmicas ou ainda polímeros e fibras têxteis. No caso dos compósitos com 
materiais têxteis, as fibras podem estar orientadas ao acaso ou todas num mesmo sentido (Figura 2.28) (ORÉFICE, 2011).

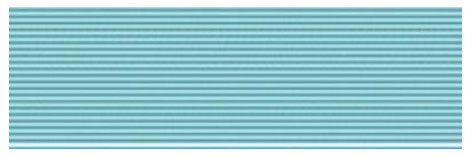

(a)

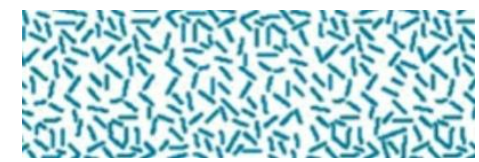

(b)

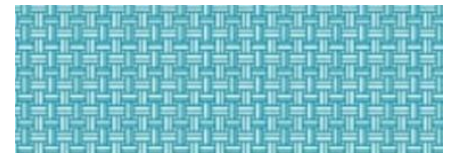

(c)

Figura 2.28. Arranjos típicos de fibras em cada camada de compósitos: (a) Fibras unidirecionais, (b) fibras descontínuas orientadas de modo aleatório, (c) fibras unidirecionais tecidas ortogonalmente (SILVA, 2011)

Dessa forma, compósitos com finalidades ópticas, estruturais, elétricas, optoeletrônicas, químicas e outras são facilmente encontrados em modernos dispositivos e sistemas (ORÉFICE, 2011).

Prevê-se que estes materiais, para além de continuarem a ter uma aplicação privilegiada em mercados avançados (militar, espacial e aeronáutico), substituam também, de forma crescente, os materiais tradicionais em aplicações mais comuns de engenharia, como a construção civil e grande parte da fabricação de automóveis (MARQUES, 2011).

O uso de fibras longas e a maior facilidade de reciclagem contribuíram decisivamente para o crescimento sustentado dos compósitos de matriz termoplástica e termorrígida nos mercados de grande consumo (Figura 2.29). As vantagens de se utilizar fibras naturais recicladas em compósitos em relação a materiais tradicionais reforçantes, tais como fibras de vidro, são: baixo custo; alta tenacidade; boas propriedades mecânicas e térmicas; redução do desgaste de máquina; facilidade de separação e biodegradabilidade, dentre outras (FINKLER et al., 2005) 


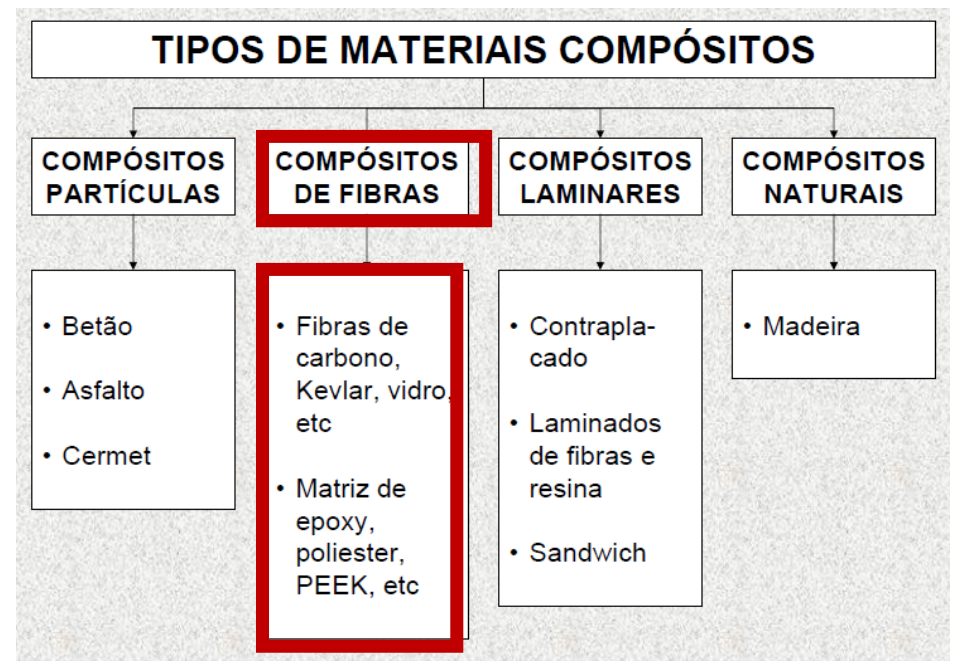

Figura 2.29. Tipos de materiais compósitos (SILVA, 2011)

Existem diversos materiais disponíveis para inúmeros fins. É importante o estudo deles para que se escolha o de melhor propriedade a um valor razoável, devendo levar em conta também sua deterioração mediante o uso. Além disso, quando em serviço, os materiais estão sujeitos a forças e cargas, portanto, é necessário avaliar suas propriedades mecânicas para a elaboração do design de um produto (UTL, 2012).

Algumas propriedades como linearidade, plasticidade, ductilidade, viscosidade e fadiga manifestam-se sob o comportamento dos materiais, entre eles, os materiais compósitos (ALVA, 2012), estando entre essas propriedades a elasticidade (Módulo de Young) e tenacidade.

O módulo de Young ou módulo de elasticidade é um parâmetro mecânico que proporciona uma medida da rigidez de um material sólido (CALLISTER, 2007) e há fatores influenciadores como: forças de coesão entre átomos e moléculas (ligações químicas e interações intermoleculares), modo como os átomos se dispõem na estrutura e, no caso dos polímeros, depende também da velocidade de deformação (UTL, 2012). É um parâmetro fundamental para a engenharia e aplicação de materiais, pois está associado à outras propriedades mecânicas, como: a tensão de escoamento, a tensão de ruptura, a variação de temperatura crítica para a propagação de trincas sob a ação de choque térmico etc. (CALLISTER, 2007).

O Módulo de Young é uma propriedade intrínseca dos materiais, dependente da composição química, microestrutura e defeitos (poros e trincas), 
que pode ser obtida da razão entre a tensão exercida e a deformação sofrida pelo material. A tensão corresponde a uma força ou carga, por unidade de área, aplicada sobre um material, e deformação é a mudança nas dimensões, por unidade da dimensão original (CALLISTER, 2007).

Conforme se constata na Figura 2.30, para a maioria dos metais, 0 módulo varia entre $45 \mathrm{GPa}(4.500 \mathrm{MPa})$ para o magnésio e até $400 \mathrm{GPa}$ (40.000 MPa) para o tungstênio. Os polímeros geralmente possuem módulo de elasticidade bem mais baixos, variando entre 0,002 e 4,8 GPa, ou seja, entre 2 e 4.800 MPa (CALLISTER, 2007).

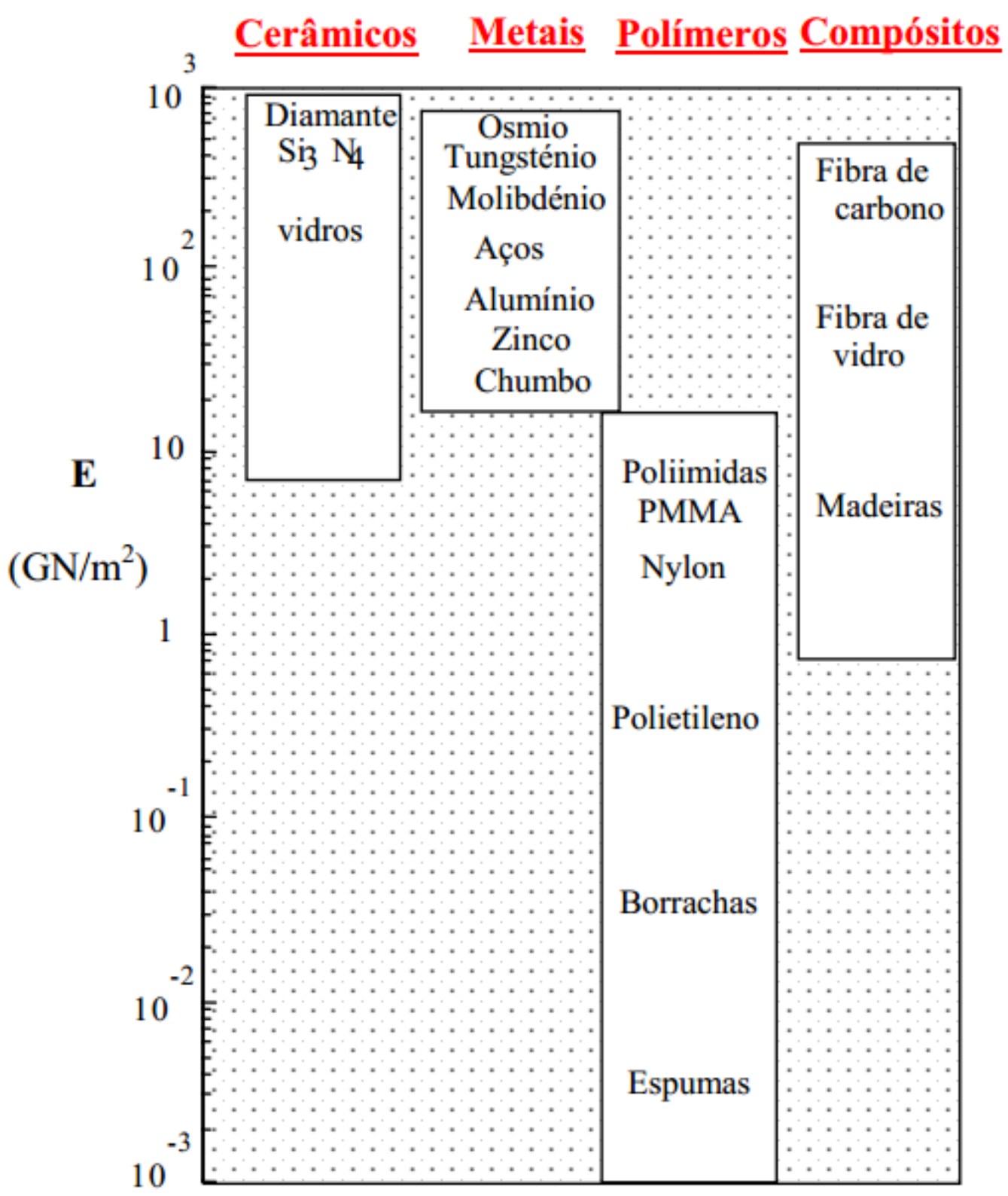

Figura 2.30. Módulos de Young de vários tipos de materiais em $\mathrm{GN} / \mathrm{m}^{2}$ ou GPa (UTL, 2012) 
Já tenacidade é uma medida de quantidade de energia que um material pode absorver antes de fraturar, ou seja, é a energia mecânica capaz de levar um material à ruptura (CALLISTER, 2007).

Para este trabalho, foram desenvolvidos compósitos fibrosos de matriz termorrígida. Foram utilizadas resinas poliméricas como a epóxi, a de poliéster e a de poliuretano.

No caso dos compósitos poliméricos, os seguintes fatores são fundamentais para suas propriedades (RABELO, 2000):

i) Propriedades dos componentes individuais e composição;

ii) Interação entre as fases (boa aderência);

iii) Razão do aspecto e porosidade da carga (o uso de materiais fibrosos eleva, até certo ponto - em detrimento de outros como partículas ou laminados, a resistência do material);

iv) Dispersão do reforço (homogeneidade do compósito).

Os compósitos fibrosos são aqueles onde as fibras se encontram aderidas a uma matriz. As fibras podem ser contínuas, longas $(\mathrm{L}>15 \mathrm{~cm})$ ou curtas $(L<15 \mathrm{~cm})$. Quanto à sua disposição, elas podem ser paralelas, unidirecionais ou bidirecionais, entre outros tipos (Figura 2.28). As fibras conferem ao material composto suas características mecânicas: rigidez, resistência à ruptura etc. $O$ tipo de reforço mais utilizado na fabricação de plásticos reforçados é o fibroso, podendo ser apresentado na forma de fibras contínuas ou curtas, podendo vir na forma de fibras curtas ou longas (FELIPE, 2012).

As resinas termofixas como a epóxi, a de poliéster e a de poliuretano perdem suas propriedades elásticas quando aquecidas na temperatura de distorção, desta forma, tornando limitado o uso para componentes estruturais, porém, tem melhor estabilidade dimensional, resistência ao calor, resistência química e elétrica do que as resinas termoplásticas (FELIPE, 2012). A cura destes materiais ocorre à temperatura ambiente, podendo ocorrer também sob 
temperatura e tempo controlados, tentando desta forma obter propriedades ótimas. O processo de cura é exotérmico e após as variações de temperaturas envolvidas e aos diferentes coeficientes de expansão térmico entre a matriz e o reforço, podem ocorrer a formação de microtrincas que levam à fratura (FELIPE, 2012).

A influência do processo de fratura ou mecanismo do dano nas propriedades mecânicas tem como pontos básicos (FELIPE, 2012):

i) Microfissuração da matriz, onde se verifica perda na rigidez e resistência do laminado composto;

ii) "Desaderência" entre as matérias primas (falta de coesão, influindo diretamente nas tensões intermateriais).

Com relação aos compósitos empregados em design e na moda, há o exemplo dos designers Azusa Murakami e Groves Alexander do Studio Swine de Londres (Figura 2.31).
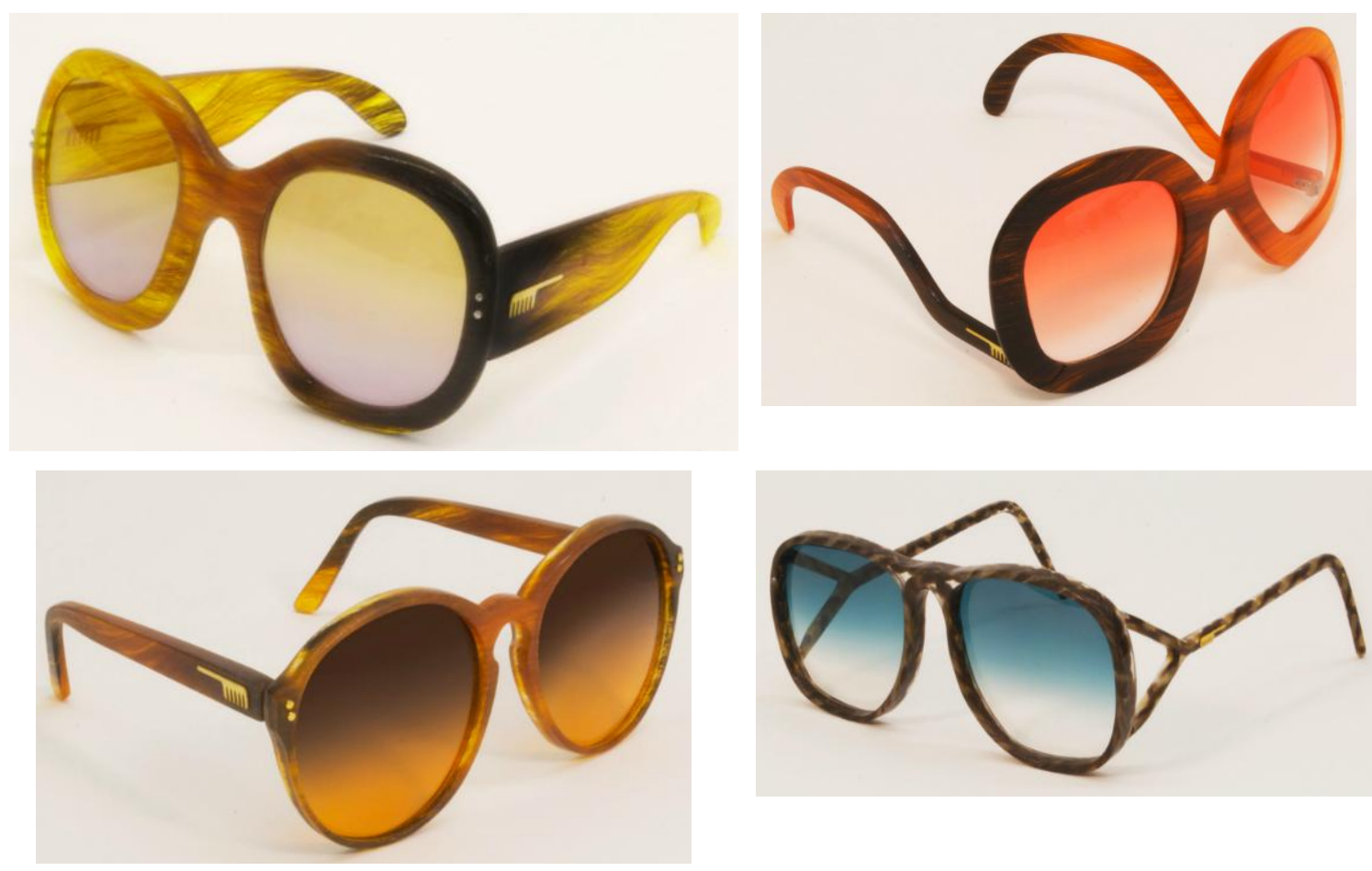

Figura 2.31. Óculos produzidos com material compósito: cabelos e resina vegetal (ECOFASHION MAG, 2012) 
Eles lançaram uma coleção de óculos sustentáveis produzidos com o reaproveitamento de cabelos humanos, os quais podem ser considerados fibras têxteis - dada sua composição (proteica) e estrutura cilíndrica - e resina vegetal. O resultado são óculos $100 \%$ biodegradáveis e livres de agente tóxicos. Os cabelos funcionam como reforço de estrutura, visto que os óculos feitos apenas com resina vegetal não seriam resistentes o suficiente para o uso (ECOFASHION MAG, 2012).

\subsubsection{Plástico Biodegradável como Matéria-prima na Produção de Compósitos Têxteis}

Com o desenvolvimento dos plásticos, matéria-prima mais barata, os artefatos tornaram-se acessíveis a todas as camadas da sociedade: mobiliários, vestuário e objetos diversos se tornaram mais acessíveis à população. Entretanto, o uso do plástico convencional, sintético por ser um subproduto do petróleo - uma fonte de energia não renovável e altamente poluidora, vem sendo questionado por ambientalistas e designers de várias áreas (FINKIELSZTEJN, 2006). Eles demoram entre 200 e 400 anos ou mais para se degradarem e no Brasil a produção é de 4,2 milhões de toneladas ao ano (BIOMATER, 2012).

O problema maior dessa grande demanda é que estudos mostram que somente $15 \%$ dos plásticos de uso comum são reciclados, devido à dificuldade para separar a grande diversidade existente, custos de lavagem, contaminação de água/tratamento de efluentes, elevados custos de logística para transporte e manuseio desses materiais.

A Tavex Corporation vem desenvolvendo, recentemente, um tecido sem poliéster em sua composição. Pioneiro no Brasil, o tecido Santista Ingeo Denim, é feito com $25 \%$ de Ingeo, primeiro plástico feito de amido do milho. Isso mostra que o plástico biodegradável pode ser uma alternativa eficaz no combate aos problemas ambientais (RECICLÁVEIS, 2011).

A soja, o milho, a palha de milho, o bagaço de cana e bambu são hoje aproveitados para plásticos, biodegradáveis ou não, em fibras têxteis e em materiais compósitos. As novas tecnologias que as empregam como matériasprimas renováveis estão ainda envoltas em incertezas, tais como a destinação 
dos resíduos gerados, impactos produzidos durante o processamento, e se adotam parâmetros sustentáveis (FINKIELSZTEJN, 2006).

O PLA (ácido poliláctico) 78 derivado do milho, o PHA (polihidroxialcanoato) 79 e o PHB derivado da cana-de-açúcar são alguns exemplos de novos materiais desenvolvidos. Embora obtidos a partir de fontes renováveis, e alguns com propriedades biodegradáveis, os bioplásticos podem emitir gases metano e dióxido de carbono em sua síntese e utilizar grandes quantidades de combustíveis fósseis, por isso, requerem uma visão consciente no seu processamento (FINKIELSZTEJN, 2006).

Alguns ecologistas levantam a questão segundo a qual os plásticos biodegradáveis estimulam o consumismo, não havendo, necessariamente, a devida atenção no que tange as questões relacionadas à sustentabilidade. Por serem utilizadas espécies geneticamente modificadas e por serem monoculturas, são utilizadas maiores quantidades de pesticidas do que nas plantações convencionais. Além disso, as extensas áreas em que são cultivadas carecem de diversidade de espécies, há redução na produção, desarticulação dos pequenos produtores, o que deixa a biodegradabilidade apenas como um conceito não tangível (FINKIELSZTEJN, 2006).

Segundo Slater (2002), o PLA é o único bioplástico com aparente potencial competitivo: $80 \%$ de cada quilograma de açúcar são transformados em produto plástico. Ele aponta que a transformação da fonte de energia para biomassa, e não a utilização de plantas na transformação de plásticos seria o primeiro benefício desse processo: a queima de biomassa compensaria a energia adicional necessária. Segundo os teóricos, as emissões seriam absorvidas pelo plantio na estação seguinte. No entanto, seria necessária a construção de nova infraestrutura para geração de energia.

No Brasil, a empresa Biocycle, localizada na cidade de Serrana no interior paulistano, produz o PHB82, que é obtido a partir da síntese da canade-açúcar, extração e purificação do polímero com solventes naturais. A solução integrada do processo torna este processo competitivo: cada 3 quilos de açúcar produz cerca de 1 quilo de plástico. A biomassa obtida a partir do bagaço de cana fornece a energia necessária para o processo.

O plástico assim pode ser utilizado também como uma das matériasprimas na produção de compósitos e não apenas para a produção de 
filamentos. Contudo, para um trabalho consciente na produção de compósitos têxteis utilizando fios ou retalhos e resinas, é preciso levar em conta todos os fatores ecológicos que envolvem o processo, não ficando preso apenas em determinadas etapas que, isoladamente, são eficientes, mas quando vistas de um modo mais amplo acabam por agredir o meio ambiente fortemente. Deste modo, pensando na ampliação de escala, seria necessário encontrar bioplásticos mais viáveis e adequados, focando também em seu Ciclo de Vida (manufatura, uso e descarte/reciclagem), para empregar na produção de compósitos têxteis.

\subsubsection{O Processo Criativo e a Seleção de Materiais e Processos}

A criatividade pode ser entendida como a interação entre processos cognitivos, características de personalidade e elementos ambientais, compreendidos de forma mais ampla, abrangendo aspectos educacionais, sociais e culturais. Percebe-se, então, a criatividade de forma multidimensional, devendo ser estudada sob diferentes ângulos ou facetas (WECHSLER, 2008). Assim, a criatividade começa com a necessidade de transformação do homem e da sociedade, exigindo observações detalhadas da realidade (FERRARI, 2011).

Qualquer projeto engloba um processo criativo, que - geralmente - parte do método "tentativas e erros", ou seja, a partir de um problema são levantados possíveis soluções aplicáveis. Durante o processo criativo, o indivíduo munido de seu repertório e vivencias pessoais, é envolvido por uma situação caótica, sujeita a inúmeras possibilidades e ideias que surgem ao tentar encontrar soluções para o problema (FERRARI, 2011). Salles (2008) denomina como "documentos de processo" o repertório que o designer utiliza para o desenvolvimento da criação.

O pré-projeto define-se por estruturas sintáticas, elementos significantes e contextuais relativos à época em que são concebidas e também definem métodos, sistemas e modelos que podem ser subdivididos em etapas quando são planejadas e elaboradas (LLAGOSTERA; HILDEBRAND, 2008).

Metodologias podem ser entendidas como conjuntos de regras, práticas e procedimentos aplicados a uma disciplina ou atividade; se uma atividade 
cristaliza-se em torno de convenções sobre como deve ser desenvolvida, estabelecem-se metodologias que irão refletir em sua estrutura e enfoque os principais pressupostos que essa convenção favorece (LLAGOSTERA, HILDEBRAND, 2008).

O desenho, que tem como característica preponderante a representação, é a impressão de uma intenção, seja artística ou projetual. O esboço é considerado apenas como as linhas gerais e iniciais de uma obra intelectual. Já o croqui compreende o registro de um processo em desenvolvimento, utilizando imagens, textos e outros meios de expressão. Pode-se afirmar que é uma ferramenta aliada à criatividade com traços rápidos, expressivos e descompromissados, sendo um elemento de linguagem em processo, permissivo de possibilidades e transformações (FERRARI, 2011).

Há também a crescente informatização como novas formas metodológicas do processo criativo: softwares como o InDesign®,Adobe Photoshop $\AA$, Illustrator $\AA^{\circledR}$ e Corel Draw ${ }^{\circledR}$ são empregados largamente em confecções e empresas ligados ao setor de têxtil e moda, bem como o Rhinoceros ${ }^{\circledR}$, aplicado à área de joalheria e bijuterias. Eles auxiliam na elaboração do desenho, dando ao usuário inúmeras variantes de traços, linhas, cores, formas, sombreados, profundidades, brilhos e, muitas vezes, oferece a possibilidade de visualizar o projeto em 3 dimensões (3D), podendo o designer ter um maior controle no momento da criação e da concepção de seu produto.

$\mathrm{Na}$ Figura 2.32 há alguns exemplos de croquis como base para o processo criativo e desenvolvimento de produtos na área de têxtil e moda e que também revelam o estilo de se seus designers. 


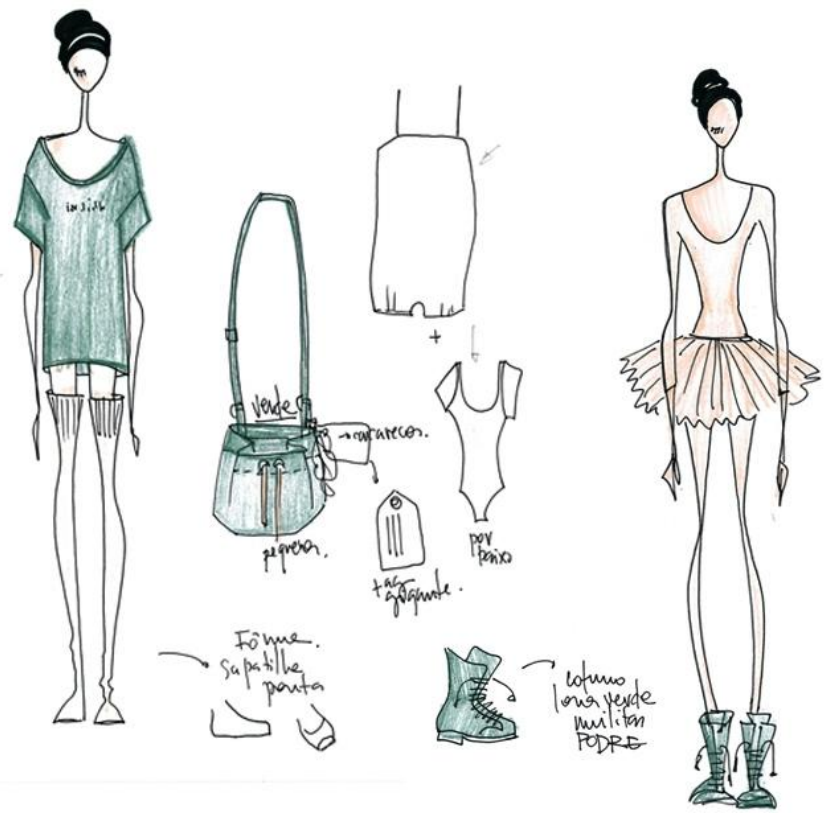

(a)

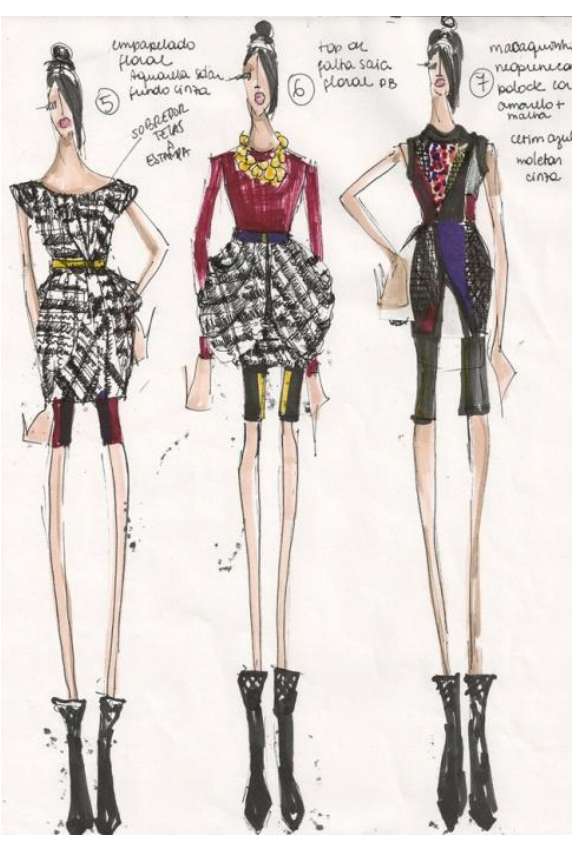

(b)

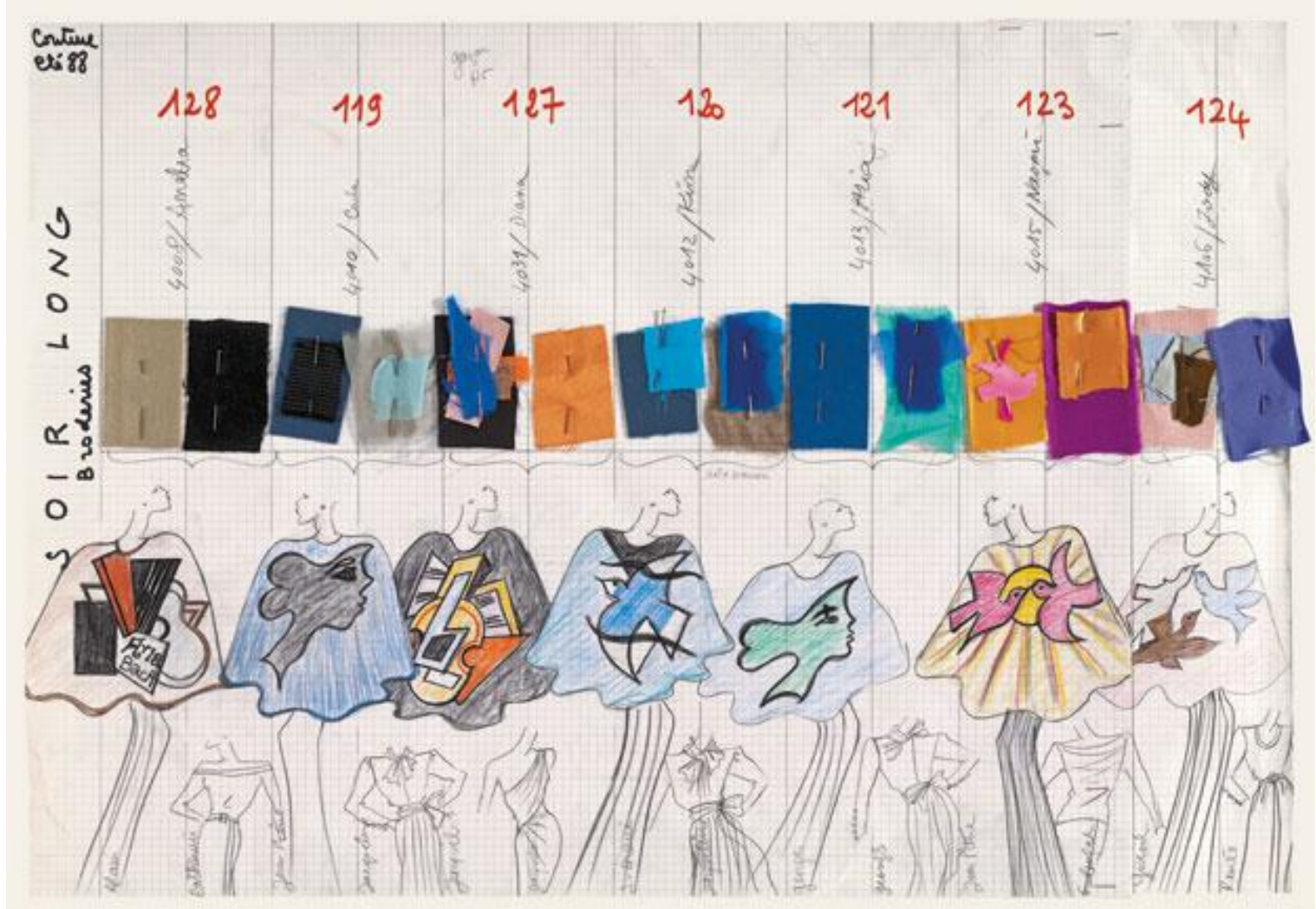

(c)

Figura 2.32. Diferentes estilos de croquis: (a) desenhos da marca New Order (SHOES FOR FUN BY VH, 2012); (b) desenhos da estilista Claudia Simões (FFW, 2012); (c) desenhos do renomado estilista Yves Saint Laurent (FFW, 2012) 
O design é uma atividade de projeto responsável pelo planejamento, criação e desenvolvimento de produtos e serviços. É um processo que busca soluções criativas e inovadoras para atender às características dos produtos, às necessidades do cliente e da empresa de forma sintonizada com as demandas e oportunidades do mercado. No universo coorporativo, é o meio que as empresas utilizam para transformar ideias e necessidades em produtos inovadores e atraentes, atributos que se tornam imprescindíveis à medida que os mercados ficam mais competitivos (TEIXEIRA, 2009).

As fases da metodologia do projeto em design são as seguintes (TEIXEIRA, 2009):

\section{Fase 1: Estudo da demanda}

i) Identificação das necessidades do cliente: o ponto de partida de um projeto é o contato entre o cliente e o designer. Nessa etapa são levantadas e analisadas as necessidades do cliente, os resultados esperados, os prazos e a verba de investimento.

ii) Proposta comercial: de posse das informações é elaborada a proposta de projeto que firma um acordo ou contrato de trabalho entre o cliente e o designer. Esse documento descreve todos os procedimentos do projeto e define as responsabilidades das partes, incluindo os recursos, prazos, honorários e formas de pagamento.

iii) Briefing de design: este é um documento também construído de forma colaborativa entre o designer ou equipe de design, e o cliente e sua equipe. Contém informações mais específicas e estratégicas sobre a empresa, os produtos e o mercado. Elas vão definir os requisitos, restrições, limites e potencialidades das soluções de projeto. 


\section{Fase 2: Desenvolvimento do Projeto}

i) Execução do projeto: o projeto nesta etapa descreve todos os detalhes necessários à fase produtiva. Além de desenhos, esta fase pode incluir a construção de protótipos para melhor visualização e avaliação do produto.

ii) Desenvolvimento de alternativas: com base nas informações do briefing são geradas as alternativas que serão avaliadas e selecionadas para elaborar a solução final a ser aprovada pelo cliente. Nesta etapa as opções são representadas em forma de layout ou modelo tridimensional, já indicando os materiais e os custos preliminares de produção.

\section{Fase 3: Produção}

i) Orçamento da produção: antes de encaminhar o projeto ao sistema produtivo são levantados os custos de produção que devem ser aprovados pelo cliente.

ii) Produção: o projeto detalhado é encaminhado aos fornecedores capacitados para a produção. Nesta etapa é importante 0 acompanhamento do processo pelo designer, a fim de garantir a qualidade final do produto.

iii) Avaliação do produto: a avaliação dos resultados é um aspecto importante do processo, pois permite a todos os envolvidos comprovar se a proposta final atende aos objetivos e resultados propostos.

iv) Documentação final: esta etapa inclui todos os documentos técnicos e ou relatório do projeto. 
O designer, além de desenvolver as ideias no papel, também avalia e combina técnicas, métodos, tecnologias, custos, normas técnicas e legais, para atender a todos os requerimentos do projeto de forma compatível com o investimento e necessidades do cliente, bem como analisa e determina quais materiais e processos de fabricação são mais viáveis na Fase 3 de produção.

Em relação à seleção dos materiais, é fundamental a escolha do mais adequado no desenvolvimento de um projeto e a aceitação do público e o bom desempenho do produto são consequências desta etapa. Uma grande dificuldade encontrada pelos designers é a de obter informações importantes no que tange a seleção dos materiais e os processos de fabricação para a concepção de um produto. Os materiais são divididos em (LDSM - UFRGS, 2012):

i) Polímeros (termoplásticos, termofixos e elastômeros)

ii) Cerâmicos (avançados, comuns e vidros)

iii) Metais (ferrosos e não ferrosos)

iv) Naturais (fibras, madeiras, minerais, entre outros)

v) Compósitos

Para a moda, a escolha dos materiais é crucial, pois torna real sua produção simbólica e fornece o meio físico com o qual se constrói uma identidade, fazendo com que as pessoas ajam como seres sociais (FLETCHER; GROSE, 2011).

À luz do design, entende-se por processos de fabricação toda e qualquer transformação aplicada sobre os materiais, para que estes deem origem ao produto. Tais processos, juntamente com a correta seleção de materiais, viabilizam e racionalizam a manufatura do projeto e proporcionam uma constante evolução das técnicas dos processos (LDSM - UFRGS, 2012) (Tabela 2.8). 
Tabela 2.8. Uso dos Processos Produtivos (LESKO, 2012)

\begin{tabular}{|c|c|c|c|c|c|c|c|c|c|c|c|c|c|c|c|}
\hline \multirow{2}{*}{\multicolumn{2}{|c|}{$\begin{array}{l}\text { Todos os Processos } \\
\text { Maioria dos Processos } \\
\text { Alguns Processos } \\
\text { Nenhum Processo }\end{array}$}} & \multicolumn{3}{|c|}{ Conformaçōes } & \multicolumn{4}{|c|}{ Cortes } & \multicolumn{4}{|c|}{ Uniōes } & \multicolumn{3}{|c|}{ Acabamentos } \\
\hline & & 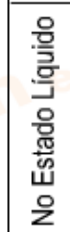 & 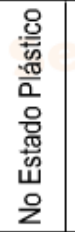 & 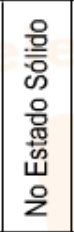 & 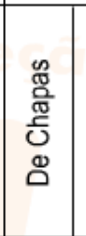 & 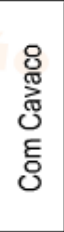 & 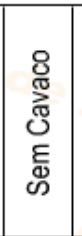 & 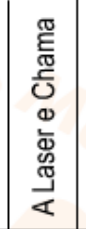 & 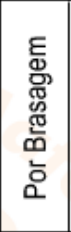 & 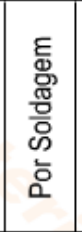 & 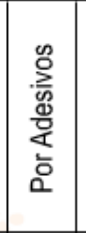 & 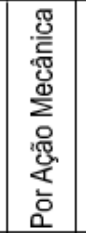 & 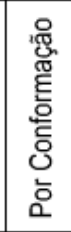 & 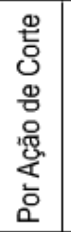 & 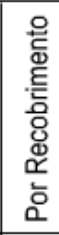 \\
\hline \multirow{2}{*}{ Metais } & Ferro & 0 & 0 & $\mathbf{O}$ & $\mathrm{O}$ & O & $\mathrm{O}$ & $\mathrm{O}$ & 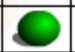 & 0 & 0 & 0 & C & $\mathrm{O}$ & \\
\hline & Não F & 0 & 0 & 0 & $\mathrm{O}$ & P & 0 & Q & 0 & 0 & 0 & 0 & O & O & \\
\hline \multirow{2}{*}{ Plásticos } & Termofixos & 0 & $\mathbf{O}$ & $\mathcal{O}$ & 0 & $\mathbf{O}$ & & 5 & $\mathcal{O}$ & 0 & 0 & 0 & 0 & P & \\
\hline & $\mathrm{m}$ & C & 0 & $\mathcal{Q}$ & 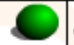 & 0 & D & 0 & $\mathcal{O}$ & 0 & 0 & 0 & $\mathcal{C}$ & 0 & C \\
\hline \multirow{2}{*}{$\begin{array}{c}\text { Borrachas } \\
\text { Elastômeros }\end{array}$} & Termofixas & O & C & 0 & $\mathrm{O}$ & & 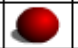 & & 0 & 0 & 0 & 0 & P & & \\
\hline & Term & $\mathcal{O}$ & 4 & 0 & 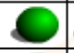 & & 0 & 0 & $\mathcal{O}$ & 0 & 0 & 0 & $=$ & & \\
\hline \multirow{3}{*}{$\begin{array}{c}\text { Vitro } \\
\text { Cerâmicos }\end{array}$} & Vidro & 0 & 0 & $\mathbf{O}$ & 0 & D & 0 & $\mathcal{O}$ & 0 & 0 & $\mathcal{O}$ & 0 & 0 & & \\
\hline & Cerâmicas & 0 & O & $\mathcal{O}$ & $\mathcal{O}$ & 0 & $\mathcal{O}$ & $\mathcal{O}$ & $\mathcal{O}$ & 0 & 0 & $\mathcal{O}$ & C & O & 1 \\
\hline & $\mathrm{Me}$ & $\mathcal{O}$ & 0 & $\mathcal{O}$ & $\mathcal{Q}$ & C) & $\mathcal{Q}$ & $\mathcal{Q}$ & 0 & & 0 & & & 0 & \\
\hline \multirow{2}{*}{$\begin{array}{l}\text { Materiais } \\
\text { Naturais }\end{array}$} & Fibras & & $\mathcal{1}$ & 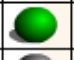 & $\mathrm{O}$ & P & $\mathbf{O}$ & & $\mathbf{O}$ & 0 & $\mathcal{O}$ & 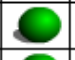 & & & \\
\hline & Madeira & $\mathcal{L}$ & 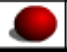 & $\mathcal{1}$ & $\mathcal{U}$ & C & - & & $\mathcal{O}$ & $\mathcal{1}$ & 0 & 1 & & U & \\
\hline
\end{tabular}

Na metodologia do projeto em design, há a possibilidade da aplicação convencional de suas fases ou do emprego da sustentabilidade no momento da escolha dos materiais e dos processos.

O eco-design ou design sustentável é um meio de reduzir ou eliminar impactos ambientais gerados pelo design convencional, substituindo produtos e processos de fabricação por aqueles não nocivos ao meio ambiente para promover um desenvolvimento sustentável (RICKEN; POZZA; TEIXEIRA, 2008). Assim, a avaliação do ciclo de vida do produto e sua reciclagem são um dos fatores importantes a serem considerados.

A avaliação do ciclo de vida visa uma abordagem menos impactante ao meio ambiente em todas as etapas constituintes do processo industrial, desde a obtenção da matéria prima até o descarte do produto já manufaturado após seu uso. Dentro da ACV deve-se levar em conta também a durabilidade do produto, sua resistência e seu potencial no que tange a reciclagem (RICKEN; POZZA; TEIXEIRA, 2008).

A reciclagem visa aproveitar resíduos, reutilizando-os, a fim de poupar a matéria prima e diminuir a quantidade de lixo acumulado. No Brasil, são produzidos cerca de 240.000 toneladas de lixo por dia e apenas $2 \%$ é reciclado por razões econômicas, posto que a reciclagem custa 15 vezes mais para as 
empresas que o descarte dos resíduos em aterros sanitários (RICKEN; POZZA; TEIXEIRA, 2008).

De acordo com Scarlato e Pontim (1992), a reciclagem não deve ser a única forma de obtenção da matéria prima, contudo, pode representar uma alternativa para a diminuição do acumulo do lixo e servir também como uma proposta de educação ambiental.

Na Tabela 2.9 é possível verificar os princípios associados ao ecodesign:

Tabela 2.9. Princípios de apoio a boas práticas (FLETCHER; GROSE, 2011)

\begin{tabular}{cc}
\hline Objetivo & Ação \\
\hline Usar recursos naturais com critério & $\begin{array}{c}\text { Minimizar o numero de etapas do } \\
\text { processamento }\end{array}$ \\
\hline Reduzir o risco de poluição & $\begin{array}{c}\text { Minimizar a quantidade e a toxicidade } \\
\text { das substâncias químicas usadas Ed } \\
\text { eliminar processos nocivos }\end{array}$ \\
\hline Minimizar o consumo de energia & $\begin{array}{c}\text { Combinar processos ou usar processos } \\
\text { que demandem baixa temperatura }\end{array}$ \\
\hline Minimizar o consumo de água & $\begin{array}{c}\text { Eliminar os processos que consomem } \\
\text { muita água }\end{array}$ \\
\hline Reduzir o volume em aterros sanitários & $\begin{array}{c}\text { Minimizar a geração de resíduos em } \\
\text { todas as etapas }\end{array}$ \\
\hline
\end{tabular}

Em linhas gerais, para a execução de um projeto com diferentes referências, deve-se considerar (TEIXEIRA, 2009):

1. Empresa: definição de um propósito; adequação ao recurso; expressão da personalidade da empresa; competitividade.

2. Produto: inovação; funcionalidade, acabamento; estruturação; reciclagem.

3. Produção: racionalização de recursos; redução de custos; redução do impacto ambiental. 
4. Consumidor: disponibilidade; conforto; facilidade de uso; atratividade.

Assim, o presente trabalho teve como principais objetivos realizar uma revisão bibliográfica sobre técnicas de reuso e reciclagem de têxteis, principalmente das fibras de algodão, bem como temas relacionados à Ecologia Industrial, ao design de moda e ao eco-design.

Quanto ao experimental também visou realizar ensaios de microscopia e de determinação de regain da fibra de algodão, bem como ensaios de tração, alongamento e microscopia em compósitos produzidos com três diferentes tipos de resinas termorrígidas (epóxi, poliéster ortoftálico e poliuretano) reforçadas com fibras têxteis de algodão, sugestão possível para a diminuição dos refugos têxteis em aterros sanitários. Para tais compósitos foram apontadas aplicações no setor da moda. 


\section{MATERIAIS E MÉTODOS}

\subsection{Entrevista com 0 Sr. Francisco de Andréa Vianna da concessionária Loga}

Após constatar o descarte dos resíduos têxteis na cidade de São Paulo por meio da revisão bibliográfica, principalmente nos bairros do Brás e do Bom Retiro - grandes polos confeccionistas da capital, foi realizada uma entrevista no dia 18/08/2011 com um dos responsáveis pela gestão da concessionária Loga, empresa que coleta os resíduos do Agrupamento Noroeste da cidade, Sr. Francisco de Andréa Vianna (Apêndice 8.2). Deste modo, observaram-se as relações que esses descartes possuem com a Política de Resíduos Sólidos do Estado de São Paulo, instituída em 2009, no que tange a disposição, coleta e reciclagem de resíduos sólidos e também com a Política Nacional de Resíduos Sólidos, instituída em 2010.

\subsection{Obtenção dos Resíduos Têxteis}

\subsubsection{Obtenção dos retalhos de poliéster e algodão para os testes preliminares}

Preliminarmente, foram utilizados retalhos e fios $100 \%$ poliéster obtidos do descarte de retalhos da confecção Korecom Modas Ltda. (Rua José Paulino, 666 - Bairro Bom Retiro - São Paulo/SP). Os retalhos são constituídos de tecido chiffon (estrutura tela), gramatura leve de $71 \mathrm{~g} / \mathrm{m}^{2}$ (Figura 3.1). Esses retalhos foram utilizados para definir e testar preliminarmente a metodologia de preparo dos compósitos a serem ensaiados. Não foi possível constatar a origem exata do tecido dos retalhos, mas provavelmente são de tecidos importados da Ásia. 


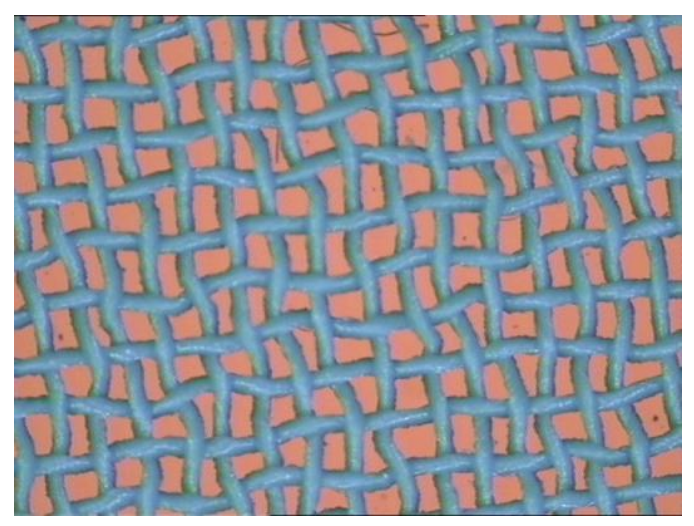

Figura 3.1. Contextura do tecido chiffon de poliéster com aumento de 51 vezes. A imagem foi captada e processada pelo sistema Video Analyser 2000 code 250 (Mesdan, Itália)

Seguidamente, foram realizados outros testes preliminares utilizando retalhos e fios de algodão oriundos da desfibragem manual de camisetas (Hering, modelo $T$-shirt, Hering, Brasil). O tecido trata-se de uma meia malha, produzida com fio penteado em fiação à anel.

\subsubsection{Obtenção dos Resíduos de Algodão para a Produção dos Compósitos}

Para os ensaios finais, foram utilizados retalhos e fios de algodão oriundos da desfibragem de uma calça jeans (M.Officer, modelo Five Pockets, Brasil), cujo tecido é fornecido pela empresa Tavex Corporation, situada na cidade de Americana/SP, composto de algodão, gramatura pesada de 12 $\mathrm{oz} / \mathrm{yd}^{2}$ (aproximadamente $410 \mathrm{~g} / \mathrm{m}^{2}$ ), estrutura sarja, com urdume tingido com corante índigo e trama sem tingimento, produzida com fio cardado em fiação open-end (Figura 3.2). A calça foi retalhada com auxílio de uma tesoura em pedaços de aproximadamente $5 \mathrm{~cm}^{2}$ e desfibrados em um liquidificador (Britânia, modelo Due Sapore, Brasil) de maneira a simular em pequena escala o processo de laminas rotativas de uma planta industrial de desfibragem têxtil. O resultado foi um resíduo têxtil semelhante ao obtido por meio de máquinas específicas de desfibragem (Figuras 3.9a e 3.10). 


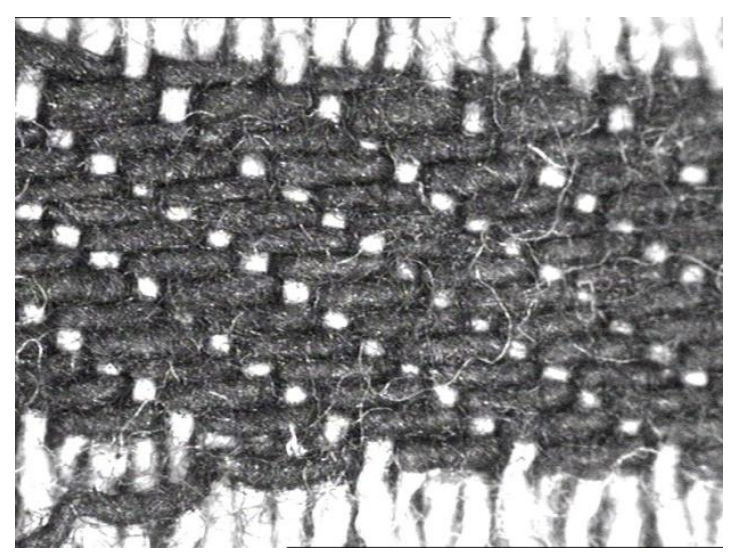

(a)

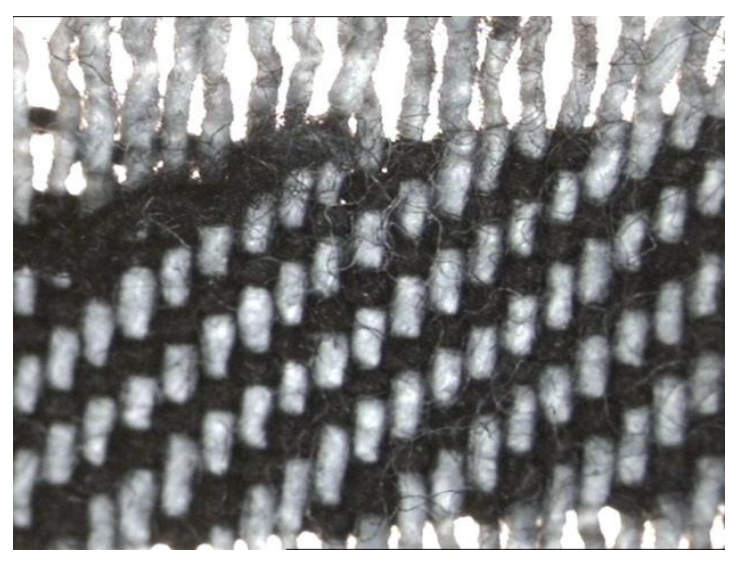

(b)

Figura 3.2. Contextura do tecido denim (a) contextura da frente do tecido denim com foco no urdume tingido e (b) contextura do verso do tecido denim com foco na trama sem tingimento. As imagens foram captadas e processadas com aumento de 32 vezes pelo sistema Video Analyser 2000 code 250 (Mesdan, Itália).

\subsection{Análises Realizadas nas Fibras de Algodão}

Utilizando amostras de fibras, foram realizados, segundo a norma ABNT NBR 13 538-1995, os ensaios de microscopia dos cortes longitudinal e transversal.

\subsubsection{Preparação dos Corpos-de-Prova e Análise Microscópica}

\subsubsection{Corte Longitudinal}

As vistas longitudinais foram realizadas com a fixação de um fio no centro de uma moldura de cartolina de $4 \times 2,5 \mathrm{~cm}$ (medidas externas) e $3 \times 1,5$ $\mathrm{cm}$ (medidas internas) (Figura 3.3). 


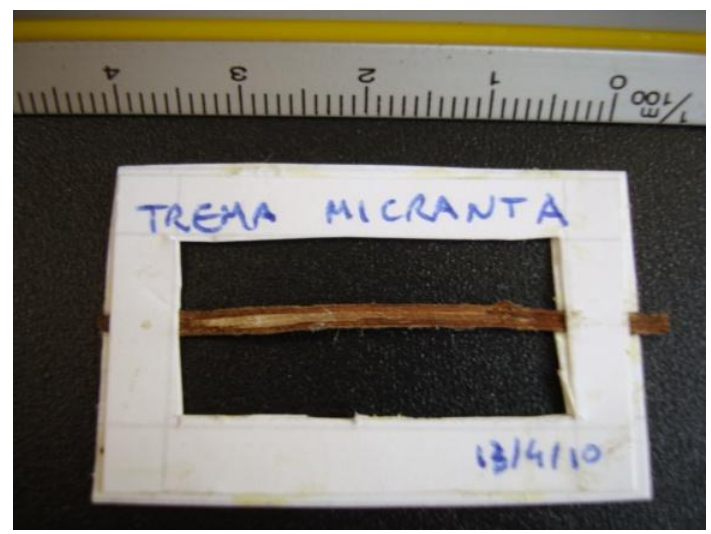

Figura 3.3. Exemplo de fixação de amostra longitudinal de fibra em moldura de cartolina

A análise foi realizada em estéreo-microscópio (Leica, modelo MS5, Alemanha) acoplado a vídeo-câmara de captação digital de imagens (Vista, Protos IV, modelo VPC 122/CH, 1/2"' CCD, Grã-Bretanha). As ampliações correspondem a 20,32, 51, 80 e 128 vezes. As imagens foram captadas e processadas pelo sistema Video Analyser 2000 code 250 (Mesdan, Itália) (Figura 3.4).

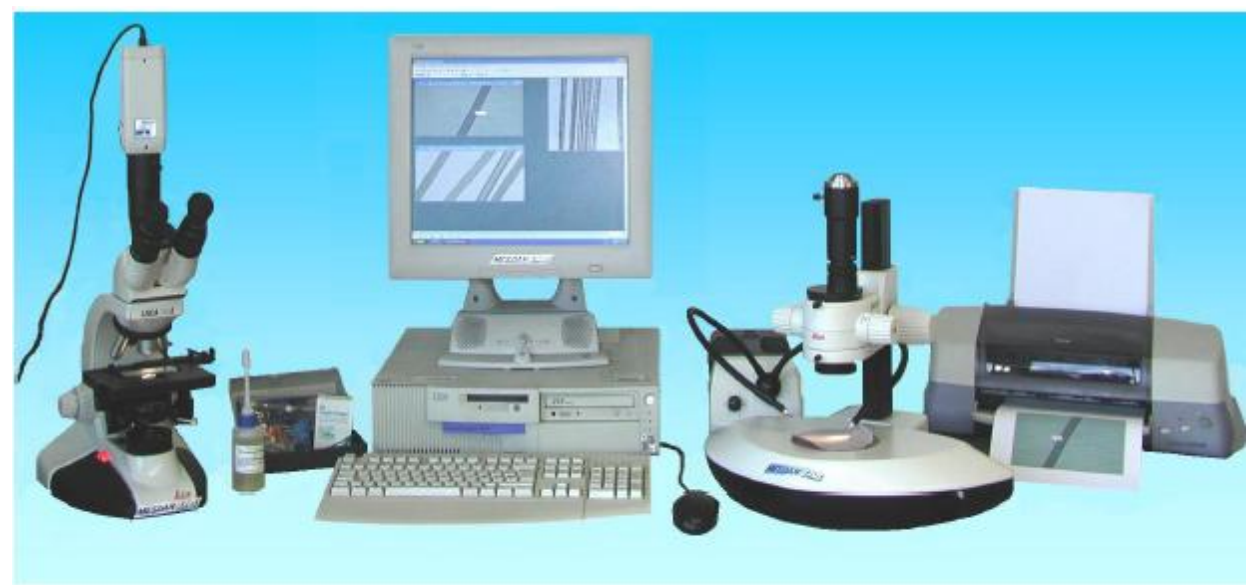

Figura 3.4. Sistema Video Analyser 2000 code 250 (Mesdan, Itália). À direita, éstereo-microscópio (Leica, modelo MS5, Alemanha). À esquerda, microscópio biológico (Leica, modelo BME, Alemanha)

\subsubsection{Corte Transversal}

Para o corte transversal, foi necessário o preparo de suporte de cartolina e resina para encapsular o fio junto ao suporte, de modo a deixá-lo bem 
esticado e centralizado para realização do corte transversal propriamente dito, conforme demonstrado na Figura 3.5 abaixo:

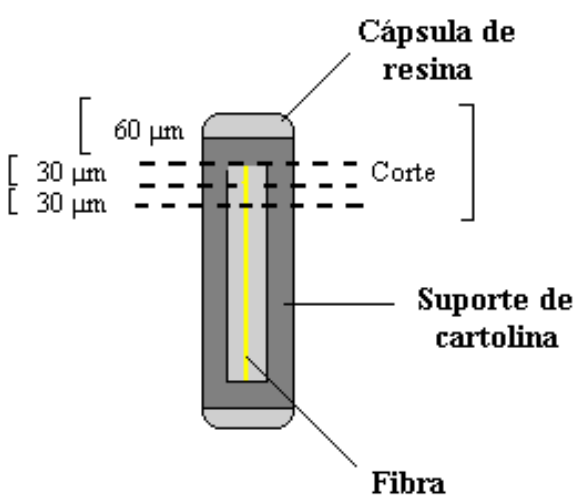

(a)
Fibra

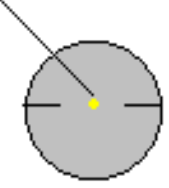

(b)

Figura 3.5. Encapsulamento do fio de algodão: (a) Esquema do fio em cápsula de resina; (b) Esquema do corte transversal (QUEIROZ, 2007).

A seguir é descrito detalhadamente 0 procedimento para encapsulamento das fibras. Essa metodologia é usada rotineiramente no laboratório do Centro Tecnológico de Têxtil e Moda do Instituto de Pesquisas Tecnológicas (CETIM-IPT) e também empregada no presente estudo.

\subsubsection{Encapsulamento do Fio de Algodão}

1 - Uma cartolina foi recortada nas dimensões de $7 \times 18 \mathrm{~mm}$, tendo centralizado em seu interior 2 retângulos de $3 \times 12 \mathrm{~mm}$, para posterior recorte (Figura 3.6). Essas dimensões do retângulo podem variar conforme o tamanho da cápsula. O retângulo deve ter dimensões tais que seja possível sua inserção na cápsula de gelatina;

2 - O retângulo foi recoberto em toda sua extensão, no seu dorso, com fita adesiva dupla-face, com $20 \mathrm{~mm}$ de largura. Vazaram-se os retângulos maiores, recortando os retângulos menores com o auxílio de um estilete.

3 - No retângulo maior retirou-se o papel siliconado da fita adesiva e foi colocado, sob a fita adesiva, um pequeno fio de algodão desfibrado, mantido 
sob pequena tensão, no centro da parte vazada, paralelamente ao eixo maior do retângulo;

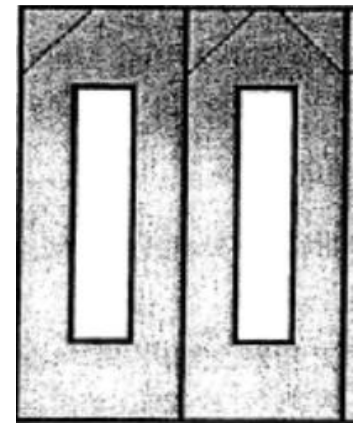

Figura 3.6. Retângulos de cartolina branca de 7 × 18 mm, vazados.

4 - Uniu-se, então, por meio da fita adesiva, os dois lados dos 2 retângulos, dobrando a cartolina ao meio

5 - Foi preparada sobre um vidro de relógio, uma pequena quantidade de solução constituída de $0,5 \mathrm{~mL}$ de base resina Technovit 7100 (Heraeus, Alemanha) e 0,5 mL de álcool etílico a 96\% P.A. Nesta solução imergem-se os suportes com o corpo-de-prova, onde ficou por 1,5 h, para intumescer completamente;

6 - Nos últimos minutos do período de intumescimento, foi preparada em um béquer de $10 \mathrm{~mL}$, uma segunda solução constituída de 0,0375 g do endurecedor I (pó) (reagente que acompanha a resina) e 3,75 $\mathrm{mL}$ de base Technovit 7100. Misturar até dissolução completa do pó;

7 - Imediatamente após terminada a preparação da solução acima, retiraram-se os suportes da primeira solução e foram imergidos nesta segunda solução, na qual deviam permanecer imersos por mais 1,5 h, em temperatura ambiente;

8 - Retirararam-se os suportes da segunda solução, foi adicionado 0,25 $\mathrm{mL}$ do endurecedor II (líquido) (reagente que acompanha a resina) e se misturou até completa homogeneização. Esta nova solução foi vertida para dentro de uma cápsula de gelatina (Capsugel - Pfizer, Cápsula Gel no 00 incolor, Brasil) e, em seguida, foi introduzido o suporte dentro da cápsula. Foi centralizado com cuidado o suporte para que as fibras ou os fios fiquem perfeitamente perpendiculares à abertura da cápsula. O material foi deixado em repouso para cura por no mínimo $2 \mathrm{~h}$, à temperatura ambiente; 
9 - Após o endurecimento da resina, a cápsula de gelatina foi dissolvida com água morna para posteriormente ser cortada, obtendo fatias transversais para os ensaios de microscopia.

Fotografias do fio encapsulado foram feitas utilizando uma câmera digital (Sony, modelo Easy Share M531, Brasil) (Figura 3.7).

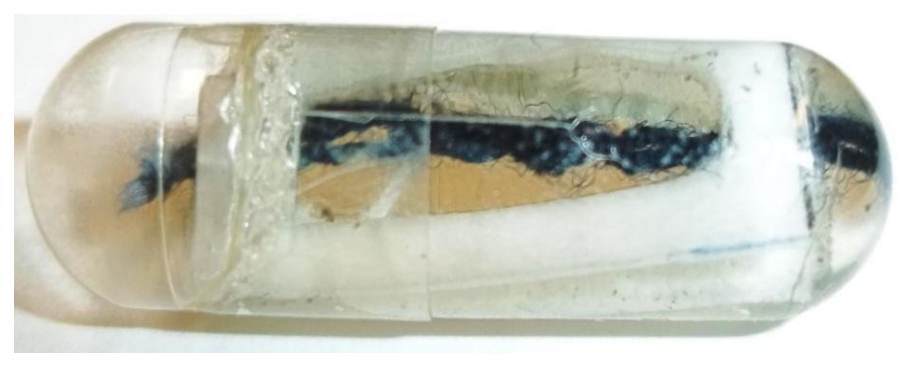

Figura 3.7. Fio de algodão encapsulado para ser cortado transversalmente obtendo fatias para as análises microscópicas (Foto do autor)

\subsubsection{Corte das Amostras}

Para a obtenção das secções transversais, monta-se a resina endurecida contendo o suporte no micrôtomo semi-automatizado rotacional (Leica, modelo RM 2245, Alemanha) equipado com cutelo tipo "C" (Figura 3.8):

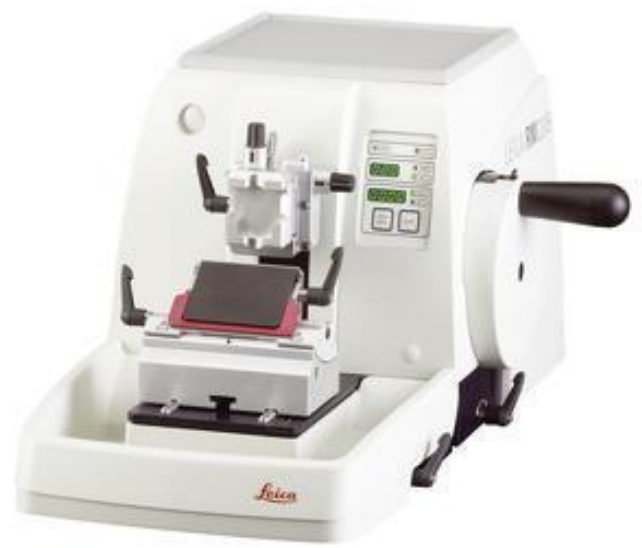

Figura 3.8. Micrôtomo semi-automatizado rotacional (Leica, modelo RM 2245, Alemanha)

No início do processo de corte, o material foi cortado com espessura maior $(100 \mu \mathrm{m})$, até desaparecer a parte superior da cartolina do suporte e começar a aparecer o fio. A partir deste instante, a espessura dos cortes foi 
regulada para $70 \mu \mathrm{m}$. No momento do corte, o fio estava perfeitamente perpendicular à lâmina de corte de modo a evitar sombras no momento da visualização das fibras no microscópio.

Duas secções transversais de um mesmo corpo-de-prova foram depositadas sobre lâminas de microscopia espalmada com uma gota de óleo mineral petrolato líquido (Nujol, Mantecorp, Brasil), cobertas com lamínulas e identificadas com o número da amostra. Os materiais foram analisados em microscópio biológico (Leica, modelo BME, Alemanha) acoplado a vídeocâmara de captação digital de imagens (Sony, Color Video Camera ESWAVEHAD, modelo 55C-DC93-P, China). As ampliações corresponderam a 128, 320 e 640 vezes. As imagens foram captadas e processadas pelo sistema Video Analyser 2000 code 250 (Mesdan, Itália).

\subsubsection{Climatização das Amostras}

Conforme a norma ABNT NBR ISO 139:2005 (antiga ABNT NBR 8428 de 1984), todos os testes foram realizados com amostras (fios de algodão) previamente climatizadas, por um período mínimo de 48 horas, a $20^{\circ} \mathrm{C}$ e umidade relativa de $65 \%$. As amostras foram condicionadas em instrumento de condicionamento para materiais têxteis ou climatizadora marca Mesdan (modelo Climatest M250-RH, Itália) (Figura 3.9).

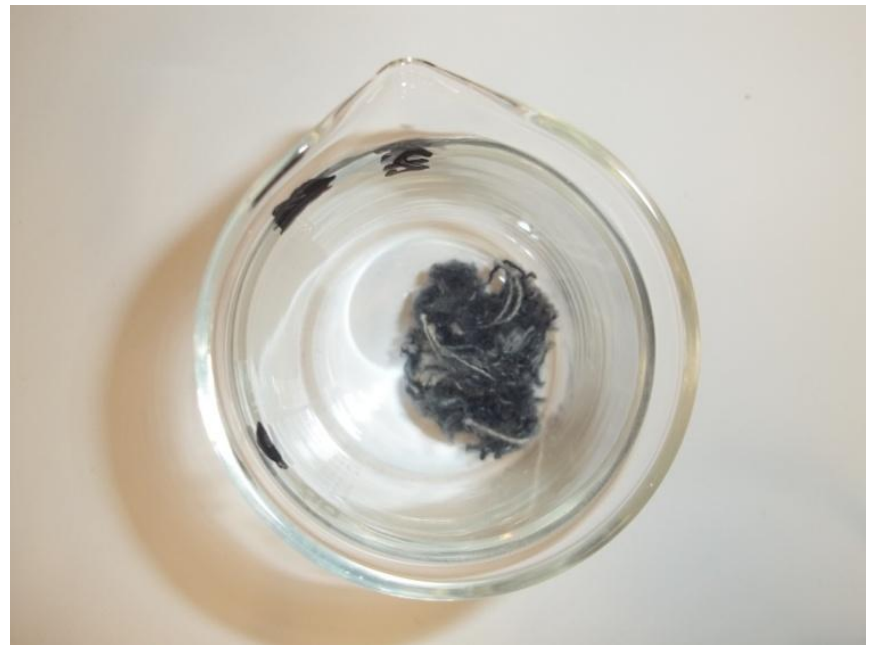

(a)

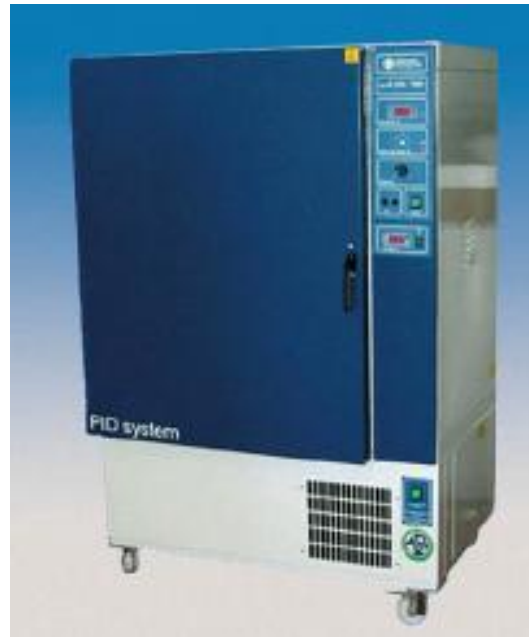

(b)

Figura 3.9. Climatização das amostras: (a) amostra de fios de algodão (b) climatizadora da marca Mesdan (modelo Climatest M250-RH, Itália) 


\subsubsection{Determinação do Teor de Regain}

Após os fios serem climatizados, houve o método que foi adaptado da norma ISO/TR 6741-4: 1987: a quantidade de umidade foi determinada pela pesagem de uma amostra condicionada (constituída de fios de algodão) em balança analítica (Sartorius, modelo ED124S, Alemanha); em seguida, foi realizada secagem em estufa com recirculação forçada de ar (Binder, modelo FD 115 , Alemanha) a $70^{\circ} \mathrm{C}$ até atingir peso constante (overnight) e, posteriormente, a amostra foi tarada novamente.

A Recuperação Porcentual de Umidade (ou "Regain") é definida como o peso de água calculado como uma percentagem do peso seco:

$$
\text { Recuperação Porcentual de Umidade }=\frac{\text { peso original-peso seco }}{\text { peso seco }} .100 \quad \text { (Equação 1) }
$$

\subsection{Produção e Ensaios dos Compósitos}

\subsubsection{Utilização de Resina Laminada (Poliéster Ortoftálico e Tereftálico)}

Para testar preliminarmente a matéria-prima e os utensílios disponíveis no laboratório multidisciplinar da Escola de Artes, Ciências e Humanidades da Universidade de São Paulo, foram desenvolvidos compósitos com resina laminada de poliéster ortoftálico (Artsol, Brasil), endurecedor ou catalisador TCatalyst (Moldflex, Brasil) e refugos têxteis oriundos de um tecido de poliéster e de uma camiseta de algodão conforme item 3.1.1.

Utilizando-se de formas de silicone disponíveis no laboratório, foram adicionadas a elas a mistura de resina laminada e o catalisador. 


\subsubsection{Utilização de Resina Epóxi}

Para esta etapa, foi utilizada a resina epóxi flexível BVR 222 (Bonivitta, Brasil) e o endurecedor BVE 0101 (Bonivitta, Brasil).

Como recipiente, foram utilizados formas de alumínio de $4 \mathrm{~cm}$ de altura, $21 \mathrm{~cm}$ de comprimento e $9 \mathrm{~cm}$ de profundidade, capaz de suportar um volume de $650 \mathrm{ml}$ (Roldan, Brasil).

Após alguns testes em relação ao volume da forma, utilizando retalhos de tecido seco, verificou-se que 20 gramas eram ideais para o tamanho da forma escolhida como padrão para este experimento. Com o auxílio de uma balança analítica (Precisa, modelo XB 220A, Suíça) foram pesados retalhos pequenos de tecido $100 \%$ algodão e de tecido 100\% poliéster separadamente.

Foram despejados na forma $150 \mathrm{ml}$ de resina misturada a $75 \mathrm{ml}$ de endurecedor e, em média após as 12 horas, a resina flexível endurece, ou seja, ocorre a cura.

\subsubsection{Utilização de Resina Epóxi e Retalhos de Poliéster}

Novamente, a resina utilizada foi a BVR 222 (Bonivitta, Brasil) da qual foram utilizados $60 \mathrm{ml}$ juntamente com 30ml do endurecedor BVE 0101(Bonivitta, Brasil).

O volume total para a produção de cada compósito foi de $90 \mathrm{ml}$ em uma forma de alumínio de $21 \mathrm{~cm}$ de comprimento, $9 \mathrm{~cm}$ de largura, $4 \mathrm{~cm}$ de altura e capaz de suportar $650 \mathrm{ml}$ (Roldan, Brasil). Inicialmente, o volume foi medido com água para precisar o quanto de resina deveria ser utilizado, visando a obtenção da espessura desejada do compósito, de aproximadamente $5 \mathrm{~mm}$.

Foram usados tecidos $100 \%$ de poliéster de cores diversas. Parte das amostras foi desfibrada manualmente e parte foi cortada em pequenos retalhos com a tesoura. Para obter a espessura de $5 \mathrm{~mm}$, a amostra desfibrada resultou em 7 gramas de poliéster na forma de fios e 7 gramas de poliéster na forma de retalhos em cada béquer, que foram pesados em uma balança analítica (Precisa, modelo XB220A, Suíça).

$\mathrm{O}$ endurecedor e a resina foram colocados em um outro béquer e misturados com um bastão de vidro. Depois de homogênea, parte da mistura 
foi colocada no fundo da forma, e por cima, foram adicionados os fios ou os retalhos e o restante da resina.

Após o endurecimento, os compósitos foram fatiados com o auxílio de uma tesoura caseira e de um estilete por ser tratar de um material flexível: cada amostra possuía $10 \mathrm{~cm}$ de altura (e mais $3 \mathrm{~cm}$ em cada uma das extremidades, para prendê-las às garras do dinamômetro), $2 \mathrm{~cm}$ de largura, aproximadamente, $5 \mathrm{~mm}$ de espessura. Este tamanho e espessura das amostras de compósitos serviram como padrão para todos os testes subsequentes.

Foram utilizadas 4 amostras de compósitos com reforço de aparas têxteis e 4 amostras de compósitos com reforço de fios têxteis.

Em cada teste no dinamômetro foram determinados a tenacidade (capacidade que o material tem de absorver energia antes de fraturar), extensão até a ruptura e módulo de Young (o qual proporciona uma medida de rigidez do material), conforme item 3.4.1.

Com esses ensaios, conseguiu-se definir a metodologia de trabalho e calibrar o dinamômetro para os demais testes finais que foram realizados posteriormente com os resíduos oriundos da fibra de algodão.

\subsection{Produção dos Compósitos para Testes Finais}

Para os ensaios finais, foram utilizadas 3 diferentes tipos de resinas bicomponentes de secagem à frio para efeito comparativo quanto às suas propriedades mecânicas. São elas:

i) Resina cristalina epóxi flexível BVR 222 (Bonivitta. Brasil) e o endurecedor BVE 0101(Bonivitta. Brasil);

ii) Resina cristalina Arazyn 1.0 (poliéster ortoftálico) (Artsol, Brasil) e endurecedor T-Catalyst (Moldflex, Brasil).

iii) Resina cristalina de poliuretano de baixa viscosidade Poly-Optic 14 (Moldflex, Brasil) e endurecedor T-Catalyst (Moldflex, Brasil); 
Como recipiente, foram utilizados formas de alumínio de $4 \mathrm{~cm}$ de altura, $21 \mathrm{~cm}$ de comprimento e $9 \mathrm{~cm}$ de profundidade, capaz de suportar um volume de $650 \mathrm{ml}$ (Roldan, Brasil) e formas de plástico de 9,7 cm de altura, $28,5 \mathrm{~cm}$ de comprimento e 17,6 de largura, capaz de suportar um volume de 3,5 litros (modelo Bioprática, Plasvale, Brasil). Uma balança analítica (Precisa, modelo XB 220A, Suíça) serviu para pesar os resíduos têxteis e as resinas para os testes.

O volume de resina utilizada (aproximadamente $200 \mathrm{~mL}$ em todos os casos) foi determinado de modo que a espessura final do compósito ficasse em aproximadamente $5 \mathrm{~mm}$. Foram produzidos:

i) corpos de prova (placas de compósitos) constituídos somente de cada uma das resinas (epóxi, poliéster e poliuretano);

ii) corpos de prova (placas de compósitos) constituídos por aproximadamente $30 \%$ em volume aparente de resíduos de fibras de algodão oriundas da calça jeans $(80 \mathrm{ml})$ e o restante de resina em relação ao volume total de cada uma das resinas (epóxi, poliéster e poliuretano), que foi de aproximadamente $200 \mathrm{ml}$. Em relação ao peso, foi utilizado aproximadamente $8,5 \mathrm{~g}$ de resíduos nos compósitos. As matrizes poliméricas possuem densidade de cerca $1,1 \mathrm{~g} / \mathrm{cm}^{3}$, implicando que a relação peso/peso foi de aproximadamente 4\% (Figura 3.10).

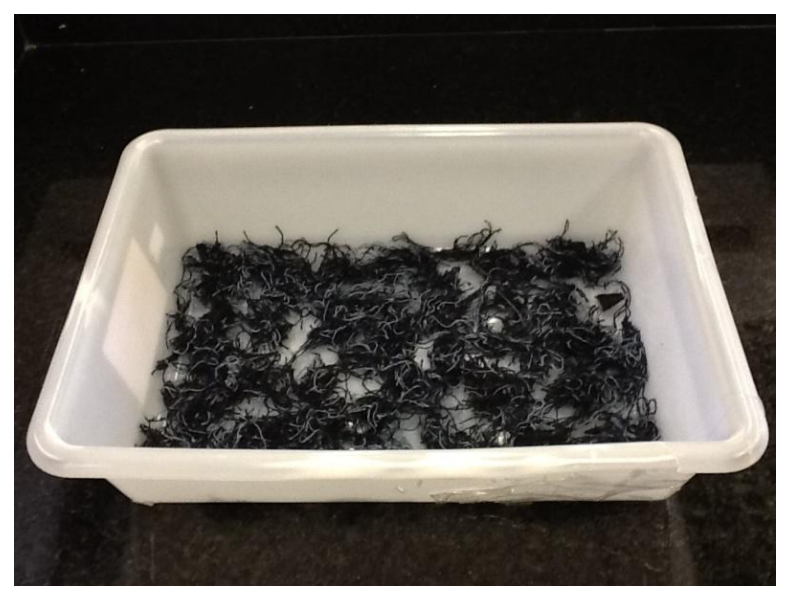

Figura 3.10. Forma de plástico (modelo Bioprática, Plasvale, Brasil) e resíduos têxteis acondicionados ao fundo (foto do autor, 18/11/2012) 
Após as resinas se solidificarem nos recipientes juntamente com os resíduos têxteis, elas foram desenformadas e se configuravam como "placas de compósitos". Foram fatiadas em 10 tiras (amostras) de $16 \mathrm{~cm}$ de comprimento, $2 \mathrm{~cm}$ de largura e aproximadamente $5 \mathrm{~mm}$ de espessura para passarem pelos ensaios de alongamento e tração do dinamômetro. A máquina utilizada para os cortes foi a serra de fita profissional (Ferrari, modelo AAS1070001, Brasil) (Figura 3.11).

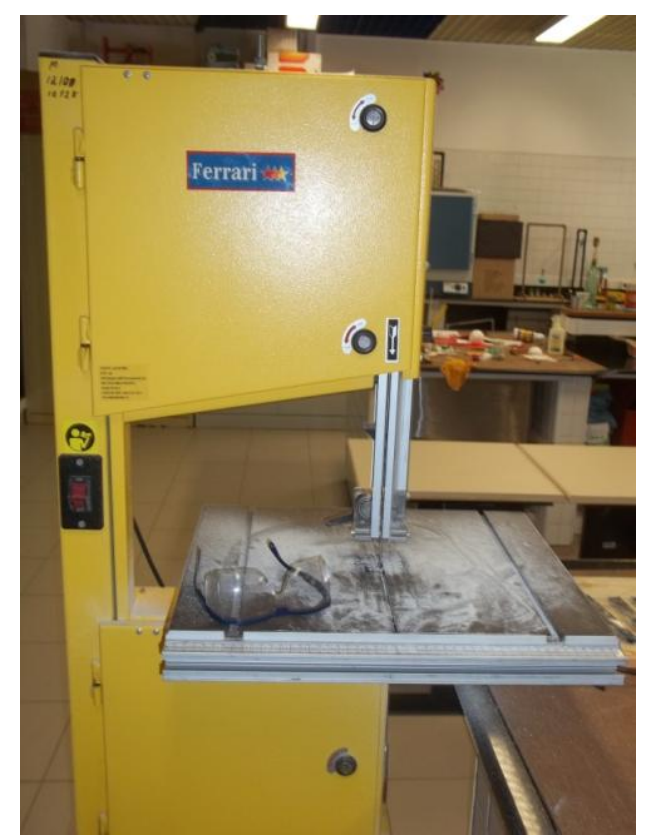

Figura 3.11. Serra de fita profissional (Ferrari, modelo AAS1070001, Brasil) utilizada para fatiar as "placas" de compósitos em tiras (amostras) (foto do autor, 18/11/2012)

As fotografias dos compósitos foram feitas utilizando uma câmera digital (Sony, modelo Easy Share M531, Brasil) (Figura 3.12).

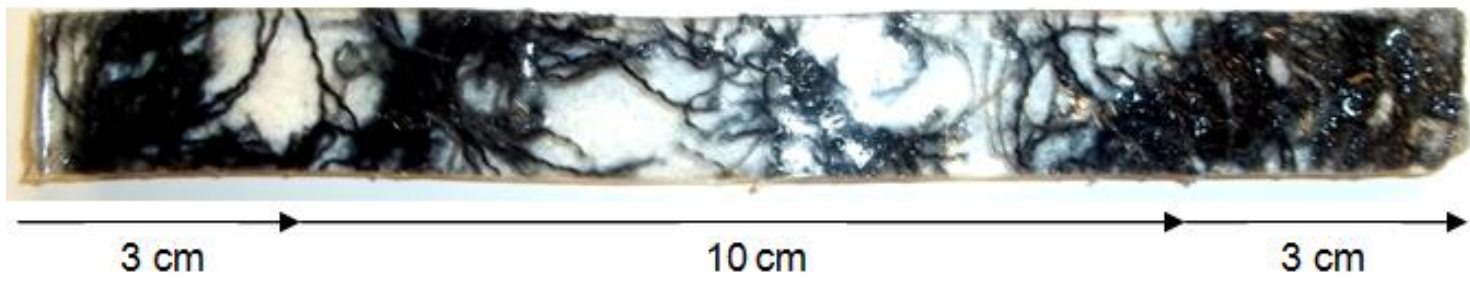

Figura 3.12. Corpo de prova de compósito: exemplo de amostra das tiras cortadas para ensaios mecânicos no dinamômetro com $2 \mathrm{~cm}$ de largura, $10 \mathrm{~cm}$ de comprimento útil de teste mais $3 \mathrm{~cm}$ em cada extremidade (Foto do autor, $18 / 11 / 2012)$ 


\subsubsection{Ensaio de Tração dos Compósitos}

Os testes dos compósitos têxteis foram realizados segundo a norma ABNT NBR 13041:2004 (Determinação da resistência à tração e alongamento Método de Tira e "Grab") para determinação das propriedades de tração e alongamento de compósitos têxteis utilizando dinamômetro ("tester machine") marca Instron (modelo 5569, Norwood, Estados Unidos) (Figura 3.13).

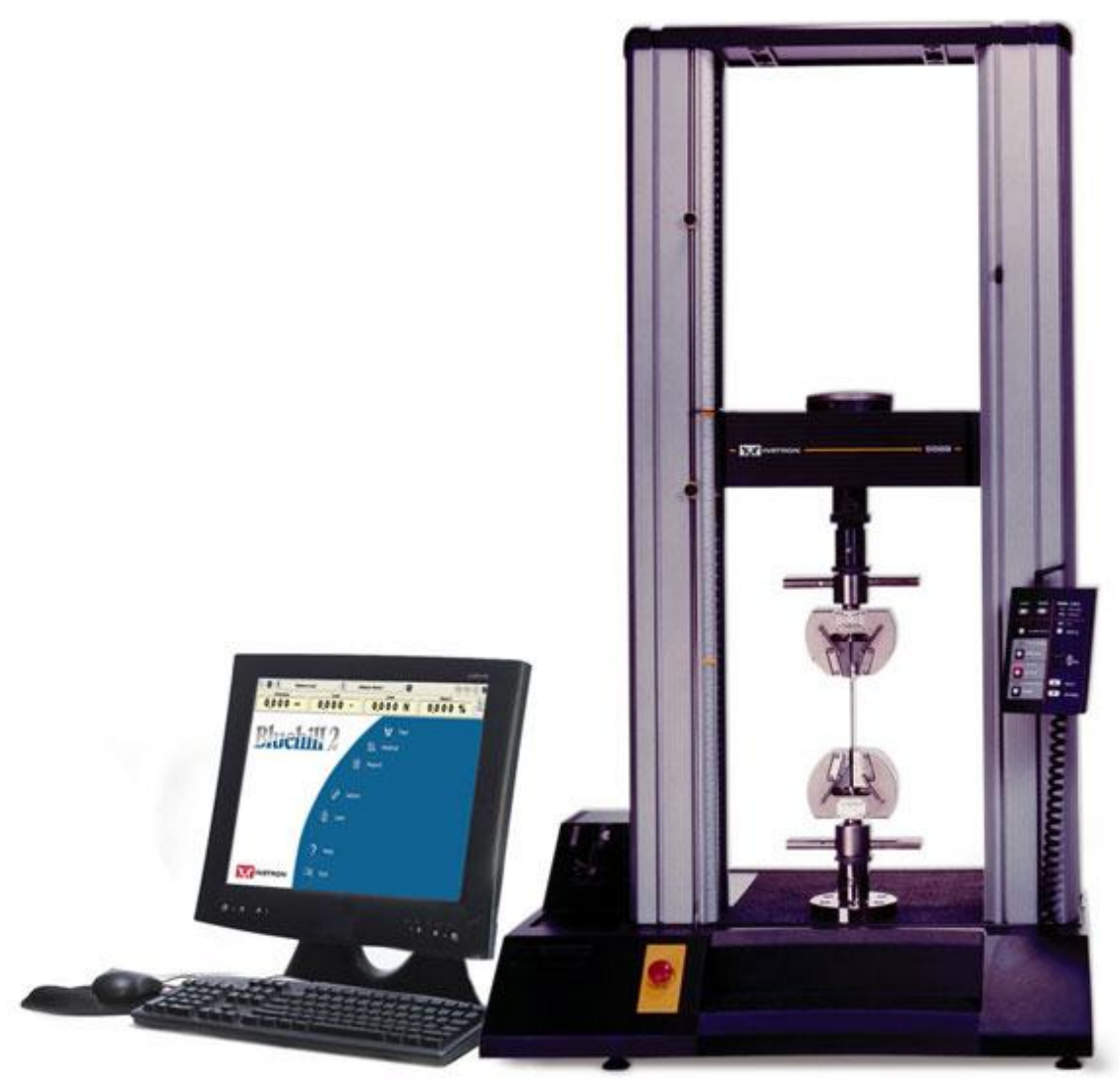

Figura 3.13. Dinamômetro marca Instron (modelo 5569, Norwood, Estados Unidos).

A célula de carga empregada para os testes correspondeu a de $1.000 \mathrm{~N}$ (ou aproxidamente $100 \mathrm{kgf}$ ) para compósitos de resina epóxi e de $50.000 \mathrm{~N}$ (ou aproximadamente $5.000 \mathrm{kgf}$ ) para os demais.

Em todos os casos, foram empregados mordentes de garras estriadas com dimensões de $3,8 \times 5,0 \mathrm{~cm}$. A distância entre as garras foi de $100 \mathrm{~mm}$ e a velocidade de deslocamento durante os testes de $100 \mathrm{~mm} / \mathrm{min}$. 
Foram determinadas as médias, desvios-padrão e coeficientes de variação dos valores de carga máxima $(\mathrm{N})$, tenacidade máxima $(\mathrm{MPa})$, extensão na ruptura $(\mathrm{mm})$ e módulo de Young $(\mathrm{MPa})$. Também foram geradas as curvas de carga máxima versus extensão para todos os testes realizados com as amostras de compósitos.

O valor de tenacidade é determinado como a seguir:

$$
\gamma=\frac{F}{A}
$$

Onde:

$\mathrm{Y}=$ Tenacidade $(\mathrm{Pa})$

$\mathrm{F}=$ Carga $(\mathrm{N})$

$\mathrm{A}=$ Área transversal do compósito $\left(\mathrm{m}^{2}\right)$

O módulo de Young (ou módulo inicial ou módulo têxtil) de uma fibra é determinado pela inclinação da curva de tenacidade-alongamento em sua parte inicial conforme equação 4 (KASWELL, 1963):

$$
\text { Módulo de Young }=\frac{\gamma_{1}}{\varepsilon_{1}}
$$

Onde:

$\mathrm{Y}_{1}=$ Tenacidade na parte inicial da curva tenacidade-alongamento (MPa)

$\varepsilon_{1}=$ Alongamento na parte inicial da curva tenacidade-alongamento (\%)

\subsubsection{Microscopia dos Compósitos (Local de Ruptura)}

Com a finalidade de observar com mais detalhes a dispersão e ancoragem das fibras de algodão nas diversas matrizes poliméricas (epóxi, poliéster e poliuretano), bem como o comportamento da ancoragem das fibras nas matrizes próximo ao local de ruptura após os testes em dinamômetro, foram realizadas microscopias em estéreo-microscópio (Leica, modelo MS5, Alemanha) acoplado a vídeo-câmara de captação digital de imagens (Vista, Protos IV, modelo VPC 122/CH, 1/2" CCD, Grã-Bretanha). As ampliações 
correspondem a 20,32, 51, 80 e 128 vezes. As imagens foram captadas e processadas pelo sistema Video Analyser 2000 code 250 (Mesdan, Itália) (Figura 3.4).

\subsubsection{Análise estatística dos resultados}

Dos valores determinados nos testes, serão calculados os parâmetros estatísticos de média, desvio-padrão e coeficiente de variação, conforme equações abaixo:

Média

$$
\overline{\mathrm{x}}=\sum \mathrm{x} / \mathrm{n}
$$

Desvio-padrão

$$
s=\sqrt{\frac{\sum(x-\bar{x})^{2}}{n-1}}
$$

Coeficiente de variação

$$
C . V .(\%)=\frac{s}{\bar{x}} \cdot 100
$$

Onde "n" representa o número de amostras em cada teste e " $x$ ", o valor de cada valor determinado no teste.

\subsection{Sugestões de Aplicação Agregados ao Design dos Compósitos Produzidos}

Após a realização dos ensaios de alongamento e tração, optou-se por utilizar a resina epóxi como matéria prima para a criação e produção de bijuterias em caráter de protótipos.

Para criar as formas em silicone, foi utilizada a borracha de silicone RTV-2 (Moldflex, Brasil), bicomponente e vulcanizada por condensação à temperatura ambiente. A densidade da borracha é de $1,31 \mathrm{~g} / \mathrm{cm}^{3}$, ou seja, 1 litro de borracha de silicone oferece, na realidade, aproximadamente $760 \mathrm{ml}$ do produto. O catalisador utilizado foi o $\mathrm{T}$ Catalyst (Moldflex, Brasil) na proporção de $4 \%$ em relação ao volume total utilizado da borracha de silicone para cada molde. Para medir os volumes apropriados de cada material foram utilizados 2 copos medidores graduados, um mais preciso para o catalisador (sem marca 
definida) e outro menos preciso para a borracha de silicone (Kaplas, Brasil). A metodologia se encontra sumarizada na Figura 3.14.

Primeiramente, uma caixa de papelão foi utilizada como forma, para que depois pudesse ser descartada facilmente. Ela foi vedada completamente com fita adesiva isolante para que a borracha de silicone, enquanto liquida, não vazasse.

As "gemas" de algumas bijuterias serviram como molde para este experimento. Elas foram afixadas no fundo da caixa de papelão com uma cola de grande aderência como a Super Bonder (Loctite, Brasil). A borracha de silicone, depois de misturada ao catalisador, foi despejada neste recipiente (Figura 3.14c).

Após 5 horas, aproximadamente, de cura, a caixa de papelão foi aberta e o molde de silicone retirado facilmente (Figura 3.14d).

Com relação ao processo criativo desenvolvido nas peças produzidas, este será abordado no item seguinte de Resultados e Discussão.

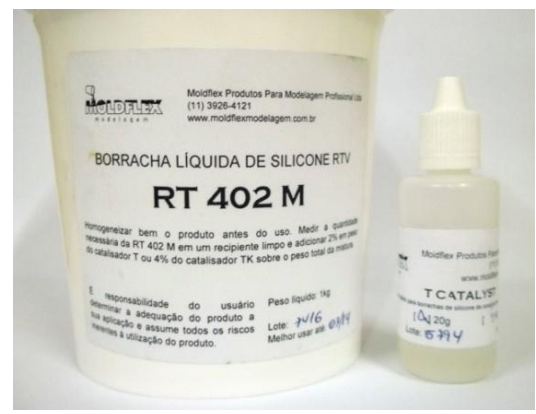

(a)

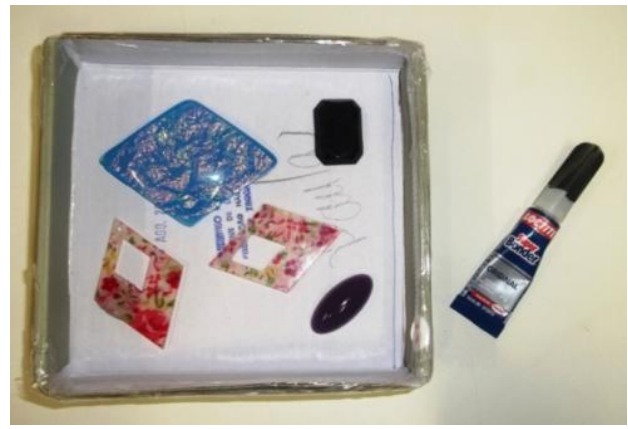

(c)

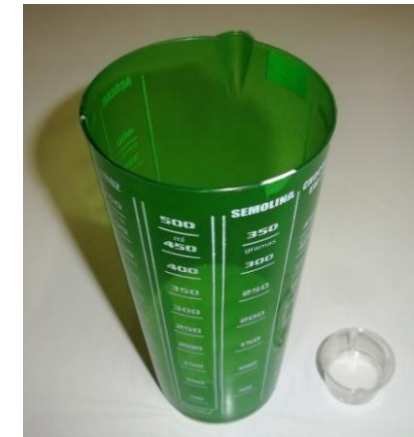

(b)

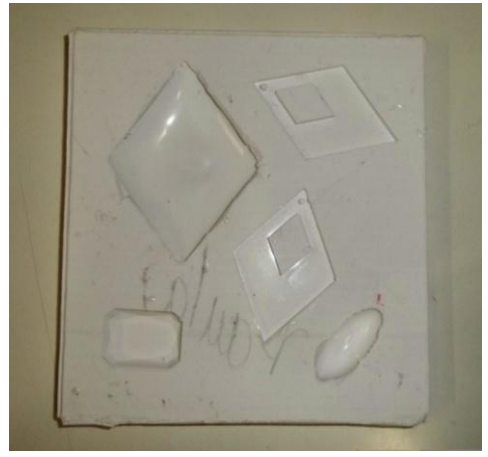

(d)

Figura 3.14. Metodologia para desenvolver moldes em silicone: materiais e utensílios utilizados no preparo das formas de silicone (fotos do autor, 08/09/2012) 


\section{RESULTADOS E DISCUSSÃO}

\subsection{Entrevista com o Sr. Francisco de Andréa Vianna da Concessionária Loga}

Após constatar o descarte dos resíduos têxteis na cidade de São Paulo por meio da revisão bibliográfica, principalmente nos bairros do Brás e do Bom Retiro - grandes polos confeccionistas da capital, foi realizada uma entrevista no dia 18/08/2011 com um dos responsáveis pela gestão da concessionária Loga, empresa que coleta os resíduos do Agrupamento Noroeste da cidade, Sr. Francisco de Andréa Vianna (Apêndice 8.2). Deste modo, observaram-se as relações que esses descartes possuem com a Política de Resíduos Sólidos do Estado de São Paulo, instituída em 2009, no que tange a disposição, coleta e reciclagem de resíduos sólidos e também com a Política Nacional de Resíduos Sólidos, instituída em 2010.

Em relação aos resíduos têxteis de bairros como o Bom Retiro e Brás, notórios polos confeccionistas, são coletados até 200 litros de resíduos por gerador, ou seja, por confecção. Contudo, este modo de recolha do lixo pode gerar incidentes, como o espalhamento deste material nas calçadas pela ação de moradores de ruas ou pessoas que possam vir a se interessar pelo valor de mercado de parte desse material, tais como canudos de papelão de bobinas de tecidos, ou ainda como ocorre especificamente na região do Bom Retiro, pelos próprios sacos de lixo.

O problema dos resíduos têxteis do Bom Retiro foi diminuído pela mudança no horário de recolhimento dos resíduos, que passou a ser realizado pela manhã, horário em que há poucos separadores e recicladores, diminuindo os estouros de sacos. Essa última situação ainda pode ocorrer no caso de lojistas que colocam o lixo na parte da tarde. Esta problemática é maior na região central e se deve às melhores oportunidades de sobrevivência dos moradores de rua nesta área. Dos 12 mil moradores de rua, acredita-se que aproximadamente 10 mil se concentram na região central.

Quanto à problemática dos resíduos, os grandes geradores são constantemente fiscalizados e, se flagradas irregularidades, são multados; a 
multa pode chegar a $\mathrm{R} \$ 14$ mil e, em caso de reincidência, o estabelecimento pode ser fechado.

No bairro do Brás, depois do Bom Retiro, também foi instituída a coleta na parte da manhã - às $7 \mathrm{~h} 30$, mudando o período, que até então acontecia à noite. Segundo Vianna, o objetivo foi o de eliminar os sacos de lixo nas calçadas durante o dia, diminuindo o risco de que sejam rasgados e seu conteúdo fique espalhado pelas ruas e, além de trazer prejuízos estéticos e sanitários, o material jogado nas vias é carregado para bueiros e galerias pluviais, criando pontos de obstrução que aumentam o risco de alagamentos. Como ocorre no Bom Retiro, quem depositar lixo na calçada fora de hora será primeiro orientado sobre a nova regra, depois notificado e finalmente multado. Deste modo, 54 toneladas de resíduos são geradas por dia na região da Operação Brás, entre material têxtil e outros.

Das aproximadas 142 mil toneladas de lixo coletadas pela Loga mensalmente, apenas cerca de 1,5 mil toneladas são coletadas e encaminhadas às cooperativas cadastradas na Prefeitura Municipal de São Paulo. A atividade destas cooperativas pode também envolver a coleta de materiais, mas uma vez que existam resíduos que não possam ser aproveitados, a Loga e a ECOURBS devem coletá-los novamente. Essa tarefa pode se tornar complexa, uma vez que cada cooperativa tem uma estrutura e organização própria. Materiais metálicos tem preferência no momento da separação para a reciclagem em detrimento de outros resíduos - como é o caso dos refugos têxteis. Mesmo com alto potencial de reutilização, os refugos têxteis são identificados pelas cooperativas como rejeitos pela dificuldade de se encontrar consumidores que os comprem.

Em relação a este material, há o recolhimento de aproximadamente 16 toneladas por dia no Bom Retiro e mais 10 toneladas no Brás - Praça da Coréia. Não há um programa de reciclagem de têxteis sendo feita em São Paulo, esses materiais são encaminhados para aterros sanitários. Da mesma forma, não existem iniciativas públicas na aplicação de tecnologias para reciclagem de entulho, outro material cuja reciclagem seria altamente vantajosa para o setor de construção civil. 


\subsection{Análises dos Fios e Fibras de Algodão}

\subsubsection{Obtenção dos Resíduos Têxteis}

Para os ensaios finais, foram utilizados retalhos e fios de algodão oriundos da desfibragem de uma calça jeans (M.Officer, modelo Five Pockets, Brasil). A calça foi retalhada com auxílio de uma tesoura em pedaços de aproximadamente $5 \mathrm{~cm}^{2}$, os quais foram desfibrados em um liquidificador (Britânia, modelo Due Sapore, Brasil) de maneira a simular em pequena escala o processo de laminas rotativas de uma planta industrial de desfibragem têxtil. Os resíduos resultantes tinham comprimento, aproximadamente, entre 2 a 3 centímetros.

O tecido denim utilizado possui gramatura pesada de 12 oz/yd ${ }^{2}$ (aproximadamente $410 \mathrm{~g} / \mathrm{m}^{2}$ ). De acordo com DINÂMICA LAVANDERIA (2012), para construir esse tecido normalmente é utilizada armação sarja $3 \times 1$, onde o título do fio de urdume é de 6,5 Ne (número de hanks - onde 1 hank corresponde a 840 jardas ou 768 metros por libra ou 0,454 kg), o qual corresponde a 90 TEX (90 gramas por 1.000 metros), ao passo que o fio de trama tem $9 \mathrm{Ne}$ ou 65,6 TEX.

A construção do tecido utilizado no presente estudo é sarja $3 \times 1$ como evidenciado na Figura 3.2a. Nota-se também pela Figura 3.2b que os fios de trama (brancos) são mais grossos que os de urdume (tingidos com corante índigo), uma vez que possuem menos torção, menos coesão entre as fibras e menor resistência.

Desse modo, pode se concluir que neste estudo o título dos resíduos têxteis, compostos de fios provenientes do tecido desfibrado, variaram entre aproximadamente de 65,6 a 90 TEX.

\subsubsection{Vista Longitudinal do Fio de Algodão}

As vistas longitudinais foram realizadas com a fixação de um fio no centro de uma moldura de cartolina como ilustrado na Figura 3.3. A análise foi 
realizada em estéreo-microscópio (Leica, modelo MS5, Alemanha) acoplado a vídeo-câmara de captação digital de imagens (Vista, Protos IV, modelo VPC 122/CH, 1/2" CCD, Grã-Bretanha). As imagens foram captadas e processadas pelo sistema Video Analyser 2000 code 250 (Mesdan, Itália) (Figura 3.4).

Esta análise teve como objetivo determinar o processo com o qual foi realizada a produção do fio utilizado neste trabalho, sendo possíveis a produção através de um sistema de fiação a anel ou de um sistema de fiação a rotor (open-end) (Figura 4.1). Este último sistema é o mais comum para produção de fios para tecelagem de denim (DINÂMICA LAVANDERIA, 2012).

A fiação por rotor, também conhecida por fiação open-end, é utilizada na fiação de fibras de comprimento muito curto e é um termo genérico utilizado para a produção de fios de fibras descontinuas por qualquer método no qual a ponta da fita ou mecha é aberta ou separada nas suas fibras individuais ou tufos, sendo seguidamente reconstituída no dispositivo de fiação a fim de formar o fio (PEREIRA, 2009).

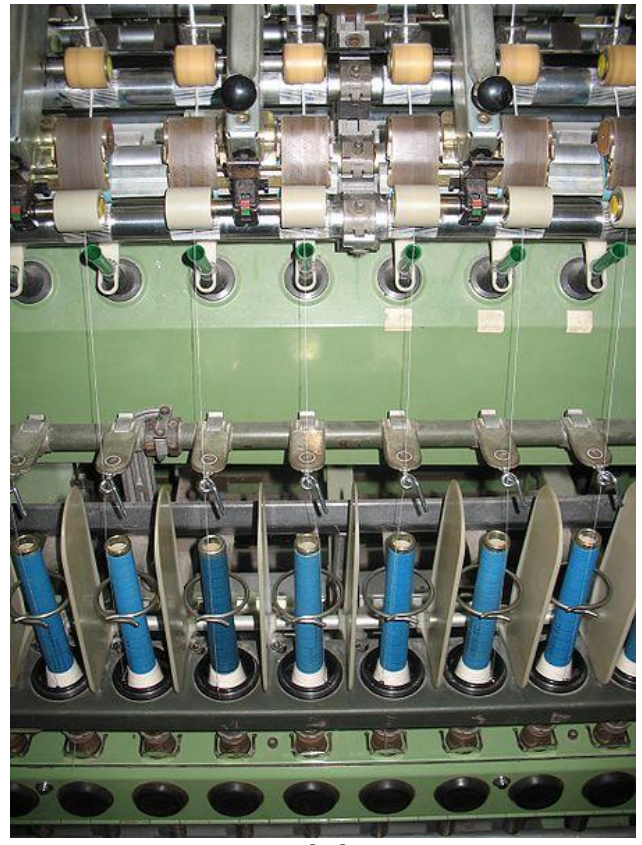

(a)

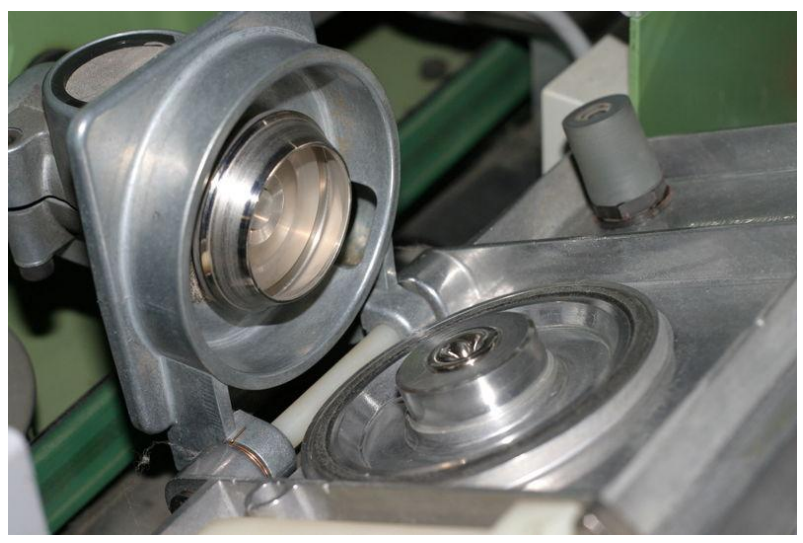

(b)

Figura 4.1. Processo de fiação: (a) fiação a anel; (b) fuso do filatório a rotor (Open-end) (COLLIER, 1970)

Segundo Pereira (2009), os fios open-end, processo notadamente utilizado para a produção do fio de denim, são mais baratos e rústicos por não 
passarem em máquinas que agregam um acabamento final mais sofisticado, como a carda, a laminadeira e a penteadeira, diferentemente do processo de fiação a anel, onde um feixe de fibras paralelizadas é bem torcido para que haja coesão e força.

$\mathrm{Na}$ fiação a anel um feixe paralelizado de fibras é bem torcido para promover coesão e força. Por outro lado, na fiação open-end, as fibras individuais não estão dispostas tão uniformemente quanto no fio produzido por fiação a anel. No fio produzido por fiação open-end a maioria das fibras estão paralelas, mas com alguns cruzamentos e com algumas fibras irregulares envolvendo o feixe principal, conforme ilustrado na Figura 4.2 (FABRICLINK, 2012).

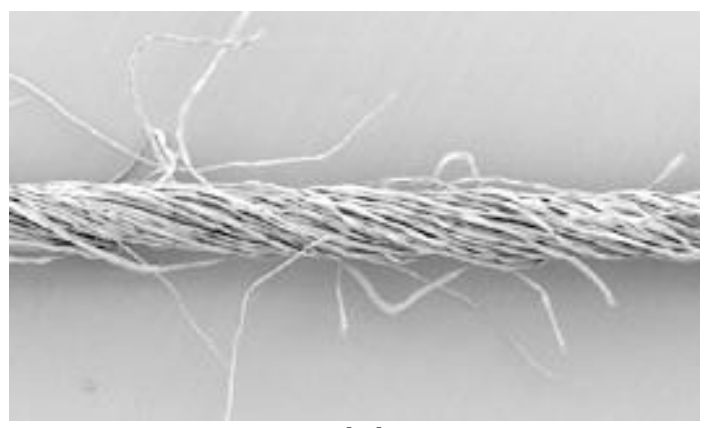

(a)

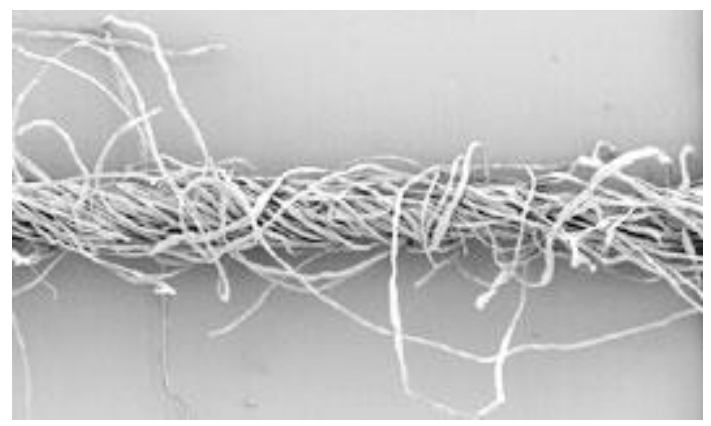

(b)

Figura 4.2. Comparação entre fios: (a) fio produzido por fiação a anel; (b) fio produzido por fiação a rotor (open-end) (HOTEL-TOWEL, 2012)

Com a ampliação da vista longitudinal dos fios de algodão utilizados no presente trabalho (Figura 4.3), foi possível observar aspectos gerais do fio e comprovar, comparando com a Figura 4.2b, que se trata de um fio que passou pelo processo open-end, uma vez que o mesmo é irregular e possui uma grande quantidade de fibrilas, que são os diversos fios mais finos soltos por entre o cabo, possuindo ainda alguns cruzamentos entre si e com algumas fibras irregulares envolvendo o feixe principal. 


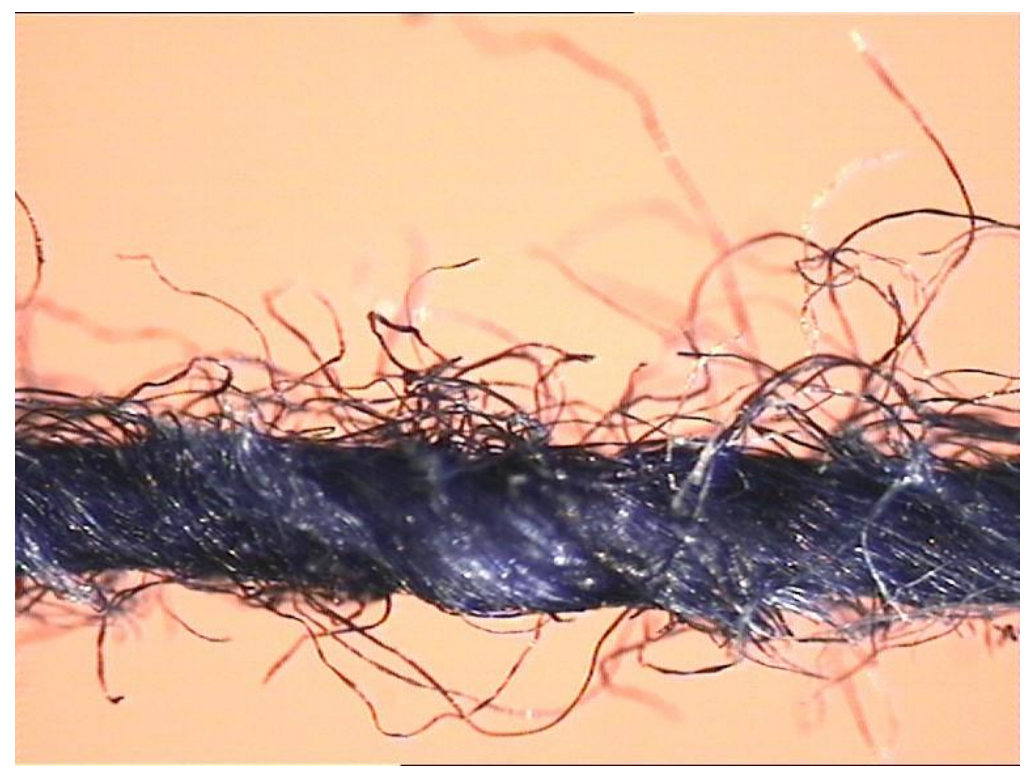

Figura 4.3. Vista longitudinal do fio de algodão do presente trabalho (aumento de 51 vezes)

A Figura 4.3 ilustra também que, apesar de ter passado por um processo mecânico de retalhamento, o fio demonstra relativa qualidade para, possivelmente, ser reutilizado como matéria prima na produção de um novo fio, contribuindo para a diminuição das toneladas de resíduos que são depositados diariamente em aterros sanitários, segundo dados da Loga (2011).

A reciclagem, além de diminuir o lixo em aterros, também reduz a pressão sobre os recursos naturais, disponibiliza um controle maior da poluição e do consumo de energia e diminui os gastos com matérias prima (ALWOOD et al., 2006).

Caso a própria indústria de fiação viesse a reciclar estes resíduos em novos processos, propiciaria condições para instaurar um dos princípios do Metabolismo Industrial, que é o de criar ciclos fechados no processamento de matérias primas - imitando os ciclos biológicos (ALMEIDA; GIANNETTI, 2006).

\subsubsection{Vista Transversal do Fio de Algodão}

Para a vista transversal, foi realizado o encapsulamento do fio de algodão em resina (Figuras 3.5 a 3.7). Para a obtenção das secções transversais, cortou-se transversalmente a cápsula contendo o fio no 
micrôtomo semi-automatizado rotacional (Leica, modelo RM 2245, Alemanha) equipado com cutelo tipo "C" (Figura 3.8).

Por meio dos ensaios de microscopia do corte transversal obtido, foi possível identificar as várias fibras compondo o fio (sendo este na verdade também um cabo composto de mais de um fio) de algodão, principal matériaprima utilizada na composição dos tecidos de denim (PEREIRA, 2009).

O corante índigo não possui alta afinidade com o algodão, deste modo, 0 tingimento fica apenas superficial nos fios de urdume, formando em cada fio um anel azul e deixando o núcleo branco, fazendo com que a solidez do tecido se torne baixa ao atrito (MARSH, 2003).

Originalmente, o denim era feito somente de algodão. Posteriormente, passou-se a fabricar o mesmo tecido também com uma mistura de algodão/poliéster. Sabe-se, entretanto, que o poliéster utilizado no urdume é de mais difícil tingimento do que quando o urdume é 100\% algodão (DINÂMICA LAVANDERIA, 2012). Ainda, a mistura com o poliéster é frequente na cadeia têxtil como forma de baratear o custo da produção (ALFIERI, 2012).

No entanto, comprova-se, pela análise da Figura 4.4b, em comparação com microscopias transversais de algodão presentes em literatura (Figura 4.5), que o fio utilizado neste estudo é de origem celulósica, natural e 100\% algodão, já que é possível observar na microscopia realizada a forma típica do formato transversal da fibra de algodão com o lúmen (pequeno oríficio) em seu interior.

Ainda, reiterando essa confirmação, compara-se outra imagem de literatura (Figura 4.4a) com a imagem da microscopia obtida no presente estudo (Figura 4.4b). Pela comparação de ambas as imagens, confirma-se na microscopia deste estudo o tingimento do corante índigo presente na superfície do fio de algodão, sendo que tal tingimento não atinge a parte mais interna do fio. 


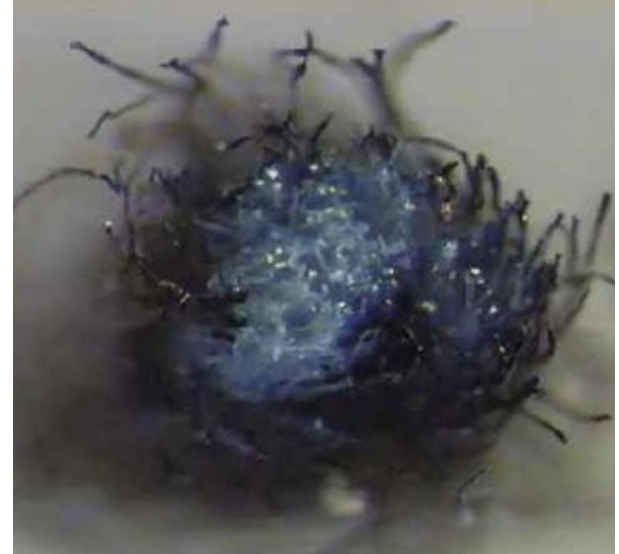

(a)

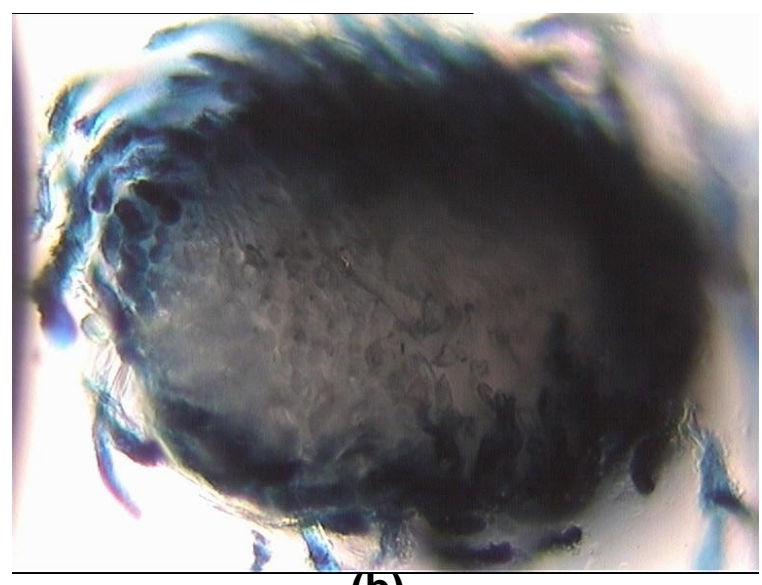

(b)

Figura 4.4. Comparação entre a imagem obtida na literatura com a microscopia do corte transversal do fio de algodão encapsulado deste estudo: (a) imagem do manual Video Analyser 2000 da Mesdan (MESDAN-LAB, 2005); (b) microscopia do corte transversal do fio de algodão do presente estudo (aumento de 320 vezes)

A certificação sobre o tipo de composição do resíduo é fundamental para a determinação dos processos de reciclagem que o mesmo deverá passar, não sendo recomendável reciclar e fiar diferentes matérias primas numa mesma linha de produção por terem, notadamente, propriedades mecânicas e químicas muito distintas (como grau de alongamento, resistência, ponto de fusão, afinidade com corantes que possam ser empregados posteriormente, entre outros) (SBRT, 2007).

Ainda, segundo SBRT (2007), recomenda-se separar, previamente, os retalhos a serem reciclados por cor e composição e, se possível, realizar ensaios que comprovem a origem desses resíduos quando pertinente.

\subsubsection{Climatização e Determinação do Teor de Regain}

As amostras de algodão foram acondicionadas num béquer e climatizadas previamente a $20^{\circ} \mathrm{C}$ e $65 \%$ de umidade relativa. Depois, foi realizada a secagem em estufa com recirculação forçada de ar a $70^{\circ} \mathrm{C}$, conforme descrito nos itens 3.2.1.5 e 3.2.1.6 de Material e Métodos.

Segundo Saville (2007) e Kaswell (1963), o teor de regain da fibra de algodão é em torno de 8,5\%. Contudo, após realizar o ensaio com 3 repetições, 
constatou-se que, para o resíduo têxtil empregado neste trabalho, os valores foram de $9,1 \%, 9,4 \%$ e $10,0 \%$, resultando em um valor de $9,5 \pm 0,5 \%$ (média e desvio-padrão da amostra). A precisão das análises é demonstrada pelo coeficiente de variação de apenas $5 \%$.

Desta forma, supõe-se que o denim utilizado passou por algum tratamento químico que desse ao fio um toque mais macio, que aumentasse sua hidrofilidade e, possivelmente, sua afinidade com o corante índigo, uma vez que o mesmo possui baixa fixação em contato com o algodão (MARSH, 2003).

Uma das hipóteses é a de que um dos possíveis processos pelo qual o denim passou foi o de mercerização na fase secundária do beneficiamento têxtil, o qual consiste na aplicação a frio de soda cáustica concentrada (hidróxido de sódio - $\mathrm{NaOH}$ ) sobre o tecido sob tensão. A soda cáustica reage com a celulose das fibras de algodão causando um intumescimento da mesma, deixando-a com um perfil mais redondo, e diminuindo as zonas amorfas da celulose (ALFIERI, 2012). Este fenômeno é ilustrado na Figura 4.5.a, onde mostra a microscopia transversal das fibras de algodão antes do processo e a Figura 4.5.b, após a mercerização. O regain do algodão mercerizado está, aproximadamente, entre 10 e 12\% (MACEDO, 2012).

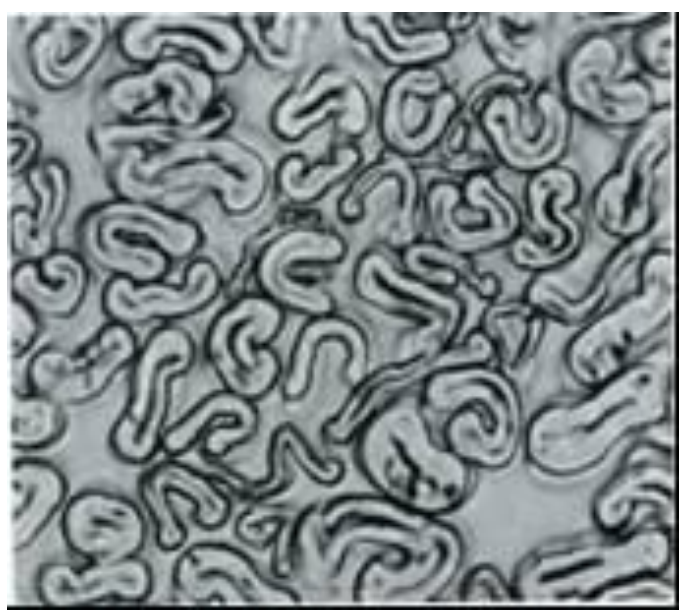

(a)

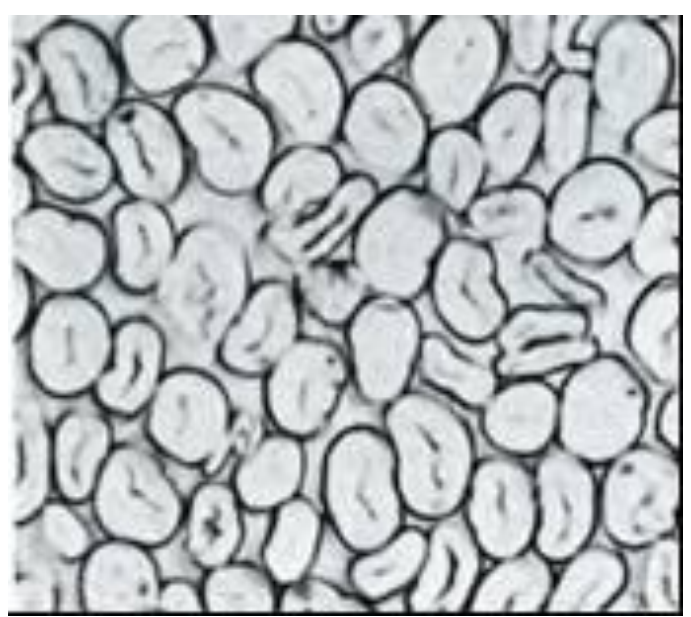

(b)

Figura 4.5. Microscopias de fibras unicelulares: (a) algodão cru (transversal); (b) algodão mercerizado (transversal); todas com aumento de 500 vezes (MALUF; KOLBE, 2003; Norma AATCC, 1995) 
Embora não seja usual utilizar este procedimento na fabricação de peças em denim por ser um processo demorado e que requer um maquinário específico (SANTANAENSE, 2012), a fabricante Santana Textiles, detentora da marca Loco, produziu uma linha de jeanswear chamada "Absynto" utilizando fios de algodão mercerizado (SANTANA TEXTILES, 2012). A linha "Absynto", além do algodão mercerizado, possui tingimento azul intenso, sarja bem definida e desbote que vai do azul profundo ao délavé (aparência de "lavado") (SANTANA TEXTILES, 2012) (Figura 4.6).
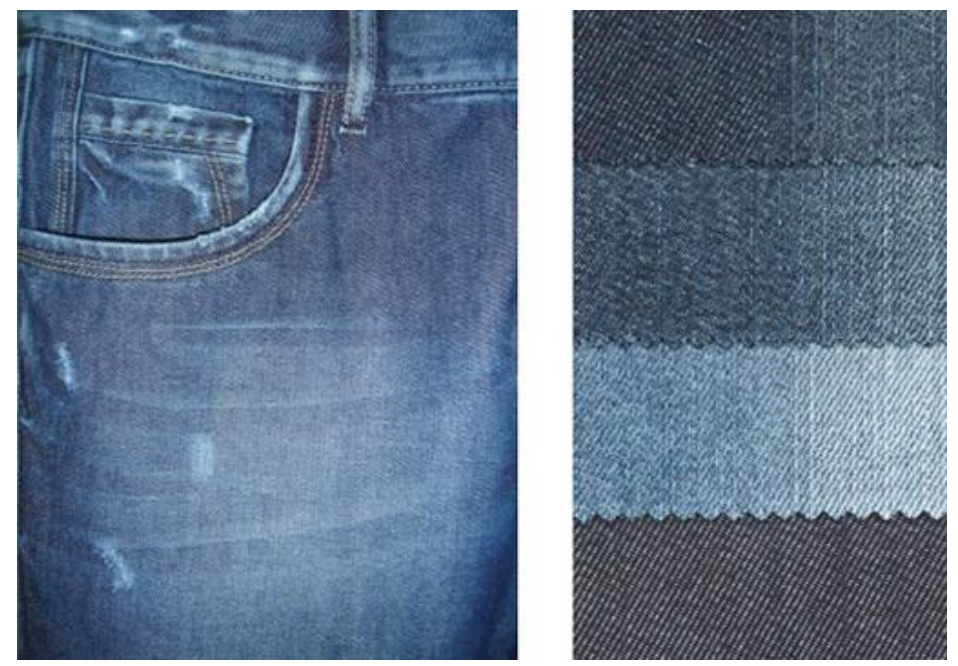

Figura 4.6. Linha de jeanswear da marca Loco utiliza algodão mercerizado (SANTANA TEXTILES, 2012).

Outra hipótese diz respeito à possibilidade também do denim, independentemente de haver sido mercerizado ou não, ter recebido, na fase terciária ou final do beneficiamento, um tratamento com enzima celulase, que participa da hidrólise (quebra das moléculas de água) da celulose - principal componente constituinte do algodão (BASRA; MALIK, 1989). As celulases são capazes de tornar os tecidos mais lisos e macios, degradando as fibras da superfície (fibras soltas e microfibrilas) e também são usadas para produzir a aparência stone washed (ou aparência de "desgaste por meio de lavagens") nos jeans (TEXTILE INDUSTRY, 2012).

De qualquer modo, pelo resultado do valor de regain obtido, conclui-se que o tecido que originou os resíduos utilizados no presente trabalho, recebeu, 
durante sua fabricação, algum processo que alterou a hidrofilidade da fibra de algodão.

\subsubsection{Das Resinas Utilizadas no Presente Estudo}

Para os ensaios deste estudo, foram utilizadas 3 diferentes tipos de resinas bicomponentes de secagem à frio para efeito comparativo quanto às suas propriedades mecânicas. São elas:

i) Resina cristalina epóxi flexível BVR 222 (Bonivitta. Brasil) e o endurecedor BVE 0101(Bonivitta. Brasil);

ii) Resina cristalina Arazyn 1.0 (poliéster ortoftálico) (Redlease, Brasil) e endurecedor MEK-P (Redelease, Brasil).

iii) Resina cristalina de poliuretano de baixa viscosidade Poly-Optic 1411 (Moldflex, Brasil) e endurecedor T-Catalyst (Moldflex, Brasil);

\subsubsection{Resina Epóxi}

O termo "epóxi" refere-se a um grupo químico que consiste de um átomo de oxigênio ligado a dois átomos de carbono que estão já ligados de alguma forma. A forma mais simples de epóxi é uma estrutura de anel de três membros conhecidos pelo termo "alfa-epoxi 'ou '1,2-epoxi". A estrutura química idealizada é mostrada na Figura 4.7 e é a característica mais facilmente identificada de qualquer molécula de epóxi mais complexa (NETCOMPOSITES, 2012).

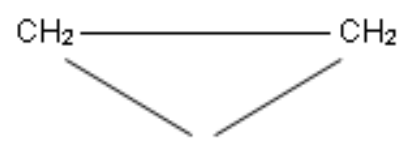

0

Figura 4.7. Estrutura química idealizada de um époxi simples (óxido de etileno) (NETCOMPOSITES, 2012) 
Uma resina epóxi ou poliepóxido é um plástico termofixo que endurece quando misturado a um agente catalisador ou "endurecedor". As resinas epóxi mais frequentes são produtos de uma reação entre epicloridrina e bisfenol-a (Figura 4.8). Atualmente as resinas epóxis são utilizadas por uma infinidade de aplicações, como revestimento interno de embalagens de cerveja, refrigerante, cítricos, entre outros. Placas de circuito impresso, a mainboard de computador, encapsulamentos de componentes eletrônicos, flash drives, pisos industriais, pranchas de surfe, tintas anticorrosivas, pintura em pó também usam epóxi como base. Existem hoje diversas empresas no mundo que se especializaram em formular produtos com características próprias para cada necessidade do usuário (SILAEX, 2012).

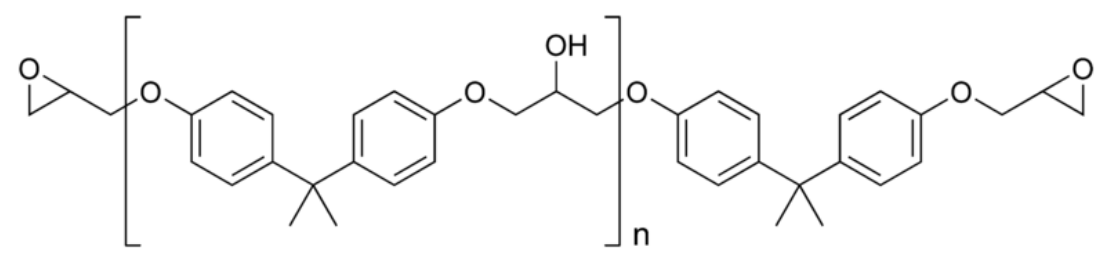

Figura 4.8. Estrutura da resina époxi bisfenol-A éter diglicil: $\mathrm{n}$ denota o número de subunidades polimerizadas, o qual é tipicamente na faixa de 0 a 25 (SILAEX, 2012)

Referente a resina epóxi BVR 222 e endurecedor BVE 0101, de acordo com o fabricante, possuem as propriedades conforme expresso na Tabela 4.1.

Tabela 4.1. Propriedades da resina epóxi BVR 222 e endurecedor BVE 0101 (BONIVITTA, 2012)

Resina epóxi BVR 222 Endurecedor BVE 0101

\begin{tabular}{lcc}
\hline Aspecto & líquido & líquido \\
Viscosidade, $\mathrm{Cps} 25^{\circ} \mathrm{C}$ & $600-750$ & $48-60$ \\
Cor & transparente & transparente \\
Densidade, $\mathrm{g} / \mathrm{ml} 25^{\circ} \mathrm{C}$ & 1,05 a 1,10 & 0,95 a 0,98 \\
\hline
\end{tabular}




\subsubsection{Resina Poliéster Ortoftálico}

Primeiramente cabe ressaltar que a resina poliéster ortoftálica termofixa, ainda que possa ter parte de sua composição substituída por componentes tereftálicos, não pode ser confundida com o polímero termoplástico puro comumente chamado poliéster ou PET (polietileno tereftalato) empregado na produção de fibras têxteis e embalagens de bebidas e alimentos. Inclusive, pelo fato da resina poliéster ortoftálica originar um material termofixo, este não pode ser reciclado posteriormente por processo de nova fusão como se dá no caso do polímero PET.

As resinas poliéster tem peso molecular bastante alto, como indicado pela etimologia da nomenclatura: "poli" significa muitos, e "ester" é uma reação química obtida da reação de um ácido mais álcool com liberação de uma molécula de água. Poliéster significa, portanto, muitos ésteres. $O$ termo "Poliéster Insaturado" indica que qualquer um dos reagentes de sua composição contém insaturação que é, geralmente, proveniente do ácido ou anidrido. Os poliésteres insaturados conferem à resina a capacidade de ser líquida e, após determinado estímulo, sofrer o processo de cura e tornar-se termoestável. A denominação insaturado está relacionada também com a presença das duplas ligações em sua cadeia molecular. Essas duplas ligações, que serão quebradas pela ação de determinado catalisador, como calor, radiação ou peróxido orgânico, irão reagir novamente entre si para originar o polímero termoestável e irreversível, ou seja, a cadeia molecular composta por simples e duplas ligações entre os átomos de carbono resultam em um produto termofixo (POLIRESINAS, 2012)

Ácido ftálico é um dos três isômeros de ácido benzenodicarboxílico, sendo os outros o ácido isoftálico e ácido tereftálico. Por vezes, o termo "ácidos ftálico" é utilizado para se referir a esta família de isômeros, mas no singular, "ácido ftálico", refere-se exclusivamente ao isômero orto (Figura 4.9) (BROWN et al, 2012). 
<smiles>O=C(O)c1ccccc1C(=O)O</smiles>

(a)<smiles>O=C(O)c1cccc(C(=O)O)c1</smiles>

(b)

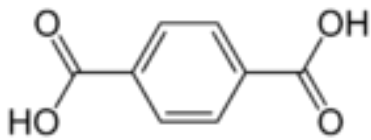

(c)

Figura 4.9. Isômeros do ácido benzenodicarboxílico: (a) ácido ftálico (ácido ortoftálico); (b) ácido isoftálico (ácido metaftálico); (c) ácido tereftálico (ácido paraftálico) (BROWN et al, 2012)

As Resinas Poliéster Insaturadas Ortoftálicas possuem em sua composição o ácido ftálico, também conhecido como ácido ortoftálico, ou seu anidrido, que se dissolve em álcool e alguns outros solvente. $\mathrm{O}$ ácido ftálico é comumente utilizado para produzir corantes, perfumes, sacarina, ftalatos e muitos outros. Esse tipo de resina é o mais comum, pois seu uso é generalizado e seu custo menor. Sua composição é feita por um ácido insaturado, um ácido saturado e um biálcool. O anidrido ftálico tende a se regenerar a partir dos meios ésteres. As propriedades mecânicas das resinas poliéster insaturadas ortoftálicas são inferiores as demais. Essas resinas podem ser utilizadas na produção de botões e assentos sanitários, podendo também ser utilizada na produção de eletro-eletrônicos, como por exemplo, na fabricação de reatores de lâmpadas (POLIRESINAS, 2012).

De acordo com a ficha técnica da resina Arazyn 1.0 fornecida pela empresa Redelease (Brasil), trata-se de uma resina de baixa reatividade e préacelerada, apresentando, no estado líquido, viscosidade média, alta transparência e ausência de coloração. Após cura, apresenta rigidez, alta transparência e cristalinidade. São sugestões de uso: fundição de objetos de artesanato e decoração como painéis, vitrais, tampos de mesa, bijuterias, estátuas, troféus; fundição de peças para sanitários como assentos sanitários, saboneteiras, lixeiras, porta-toalhas e lavatórios. Juntamente com a fibra de vidro pode ser utilizada na construção civil compondo telhas (processo manual), domus e venezianas. 
Suas propriedades, de acordo com o fornecedor, são conforme expresso na Tabela 4.2.

Tabela 4.2. Propriedades da resina poliéster ortoftálico Arazyn 1.0 (REDLEASE, 2012)

\begin{tabular}{lc}
\hline Viscosidade Brookfield (25C/LVF sp 2/12 rpm), cps & $1400-1800$ \\
Gel Time (25C c/ 1,0 g MEK-P em 100 g resina), minutos & $10^{\prime}-14$ ' \\
Intervalo de Pico, minutos max. & 22 \\
Pico Exotérmico, ㅇ max. & 150 \\
Índice de Acidez (em solução), mg KOH/g resina max. & 30 \\
Aspecto & cristal \\
Cor (curada) & incolor \\
Teor de Sólidos, \% min. & $68 \%$ \\
\hline
\end{tabular}

\subsubsection{Resina Poliuretano}

Poliuretano é um polímero que compreende uma cadeia de unidades orgânicas unidas por ligações uretânicas (RANDALL, 2002) (Figura 4.10).

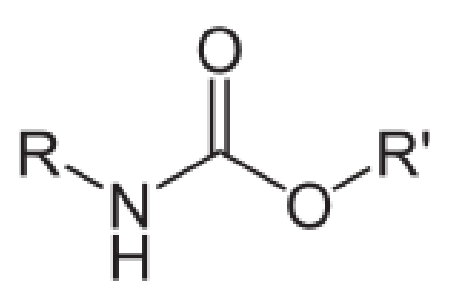

(a)

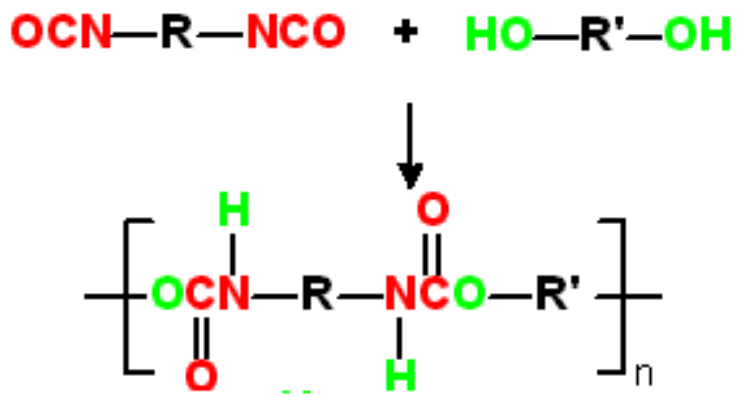

(b)

Figura 4.10. Poliuretano: (a) esqueleto do poliuretano é formado por carbamatos; (b) esquema de síntese de um poliuretano (RANDALL, 2002) 
A resina poliuretano pode ser definida como qualquer resina resultante da reacção de di-isocianatos (tal como tolueno di-isocianato) com uma amina, fenol, ou um composto hidroxílico ou carboxílico para produzir um polímero com grupos isocianato livres, utilizado como revestimentos protetores, envasamento ou resinas de fundição, adesivos, borrachas, e espumas, e em tintas, vernizes e adesivos (THE FREE DICTIONARY, 2012).

Referente à resina cristalina de poliuretano de baixa viscosidade PolyOptic 1411, fornecida pela empresa Moldflex (Brasil), de acordo com a ficha técnica, trata-se de resina incolor cristalina, fácil de misturar, que cura rapidamente tornando-se um plástico rígido super resistente. Possui boa deflexão de temperatura, o que é especialmente útil em algumas aplicações de prototipagem, pode ser pigmentada para se obter peças coloridas e transparentes e não amarela com o tempo.

Suas propriedades, de acordo com o fornecedor, são conforme expresso na Tabela 4.3.

Tabela 4.3. Propriedades da resina poliuretano Poly-Optic 1411 (MOLDFLEX, Brasil)

\begin{tabular}{lc}
\hline Razão de mistura & $1 \mathrm{~A}: 1 \mathrm{~B}$, volume \\
Dureza, Shore A ou D & $\mathrm{D} 80$ \\
Tempo de Trabalho, massa de $1 \mathrm{~kg}$ & $9 \mathrm{~min} / 7 \mathrm{~h}$ \\
Exotermia máxima $(0,5 \mathrm{~kg}$ de massa) & $109^{\circ} \mathrm{C} / 38^{\circ} \mathrm{C}$ \\
Desmoldagem (horas) & $0,5\left(1,2^{\prime \prime}\right) / 48-96$ \\
Peso específico & 1,07 \\
Viscosidade 2 min. depois da mistura $(\mathrm{cP})$ & 600 \\
\hline
\end{tabular}

\subsection{Produção de Compósitos Reforçados com Resíduos Têxteis}

\subsubsection{Utilização de Resina Laminada (Poliéster Ortoftálico)}

Para testar preliminarmente a matéria-prima e os utensílios disponíveis, foram desenvolvidos compósitos com resina laminada de poliéster ortoftálico 
(Artsol, Brasil) (Figura 4.11.a), endurecedor ou catalisador MEK-P (Redelease, Brasil) e refugos têxteis oriundos de uma camiseta de algodão (Hering, modelo T-shirt, Brasil) (Figura 4.11.b e 4.11.c) retalhada com o auxílio de uma tesoura.

Observa-se que o fornecedor da resina laminada de poliéster ortoftálico (Artsol, Brasil) não disponibilizou a ficha técnica da mesma, informando somente através de seu site que se trata de uma resina ortoftálica com excelente flexibilidade e é indicada para moldes ou laminação com fibra de vidro (ARTSOL, 2012). Deste modo, esta resina somente foi utilizada nos testes preliminares, sendo substituída nos testes seguintes pela resina Arazyn 1.0, sobre a qual se possui um número maior de informações técnicas (conforme item 4.1.5.2).

O processo de polimerização de uma resina se dá mediante três fenômenos básicos que são (FELIPE, 2012):

i) Tempo de gel: é o tempo transcorrido, após a mistura da resina com o catalisador (com ou sem acelerador), é o início do endurecimento da resina, quando a mesma atinge um estado gelatinoso;

ii) Gelatinização: é um período entre o começo e o fim da polimerização. É o período intermediário em que a resina passa do estado líquido para o estado sólido.

iii) Tempo de cura: é o período que após a mistura com o catalisador (com ou sem acelerador) a mesma fica totalmente polimerizada. É o tempo de polimerização ou de cura.

Utilizando-se de formas de silicone disponíveis no laboratório, foram adicionadas a elas a mistura de resina laminada e o catalisador (Figura 4.11.d e 4.11.e).

Deste modo, foram produzidos compósitos totalmente enrijecidos e de cor esverdeada que, naturalmente, não satisfaziam os requisitos necessários para o resultado final do trabalho, tais como possuir coloração cristalina (Figura 4.11.f) 


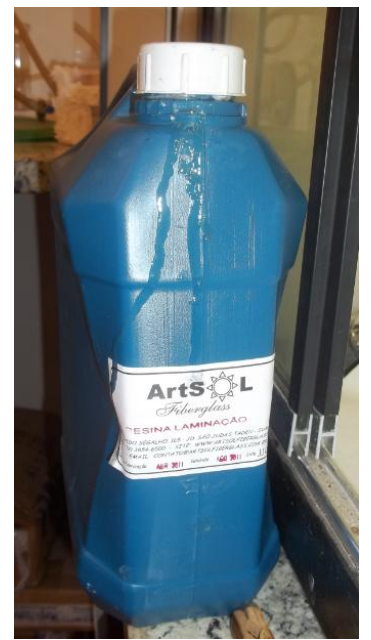

(a)

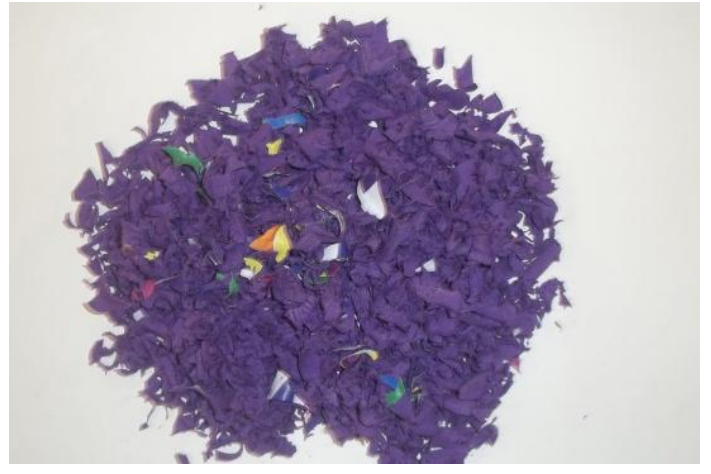

(c)

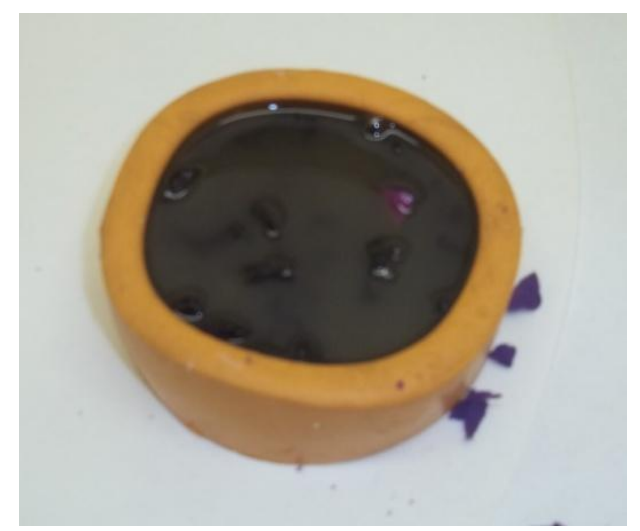

(e)

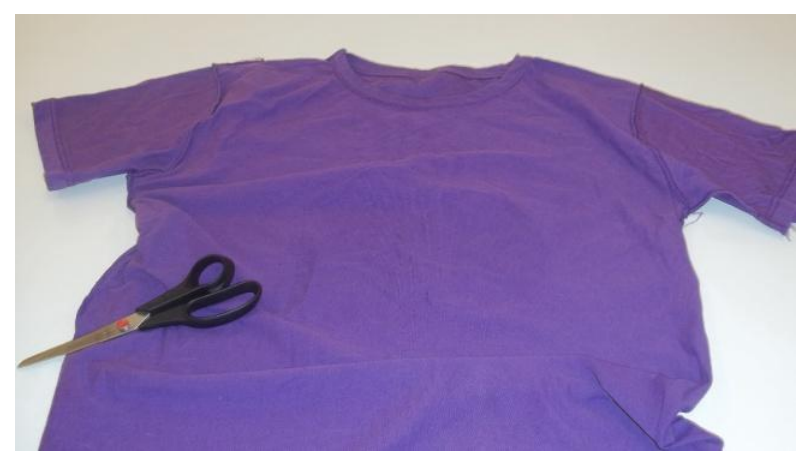

(b)

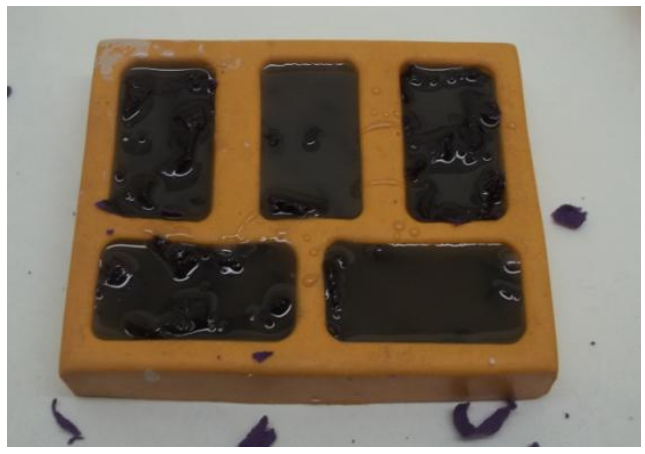

(d)

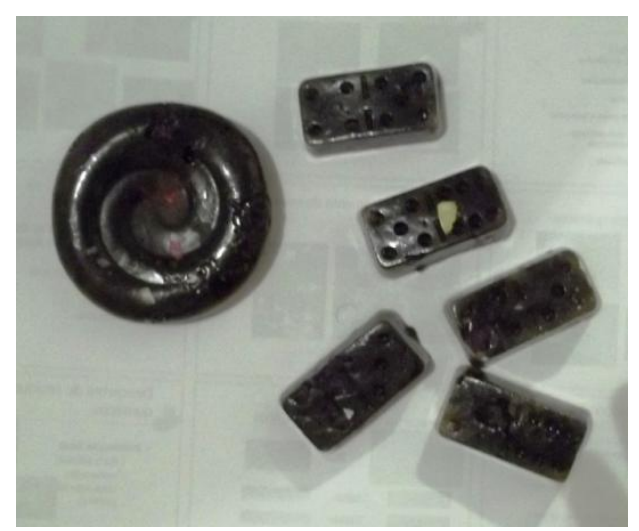

(f)

Figura 4.11. Metodologia desenvolvida para compósitos feitos de resina laminada de poliéster: (a) resina usada para a produção de compósitos; (b) camiseta (Hering, modelo T-shirt, Brasil), produzida $100 \%$ com fibra de algodão; (c) o resultado de seu retalhamento com a tesoura; (d) e (e) formas de silicone foram preenchidas com resina laminada de poliéster e retalhos de fibra de algodão; (f) compósitos acabados, extremamente rígidos e de cor escura (Fotos do autor, 20/08/2011) 
Para esta etapa, não foram realizados nenhum dos ensaios posteriores descritos no capítulo "Materiais e Métodos". Contudo, verificou-se questões relacionadas ao preparo da matéria-prima (se era viável utilizar retalhos "grosseiros" produzidos manualmente), quais utensílios de laboratório eram necessários durante o processo (a balança analítica, por exemplo, a qual não foi utilizada nesta etapa), manuseio e tempo de cura da resina e a duração do experimento.

\subsubsection{Utilização de Resina Epóxi}

Para esta etapa, após testes preliminares com a resina laminada de poliéster (Artsol, Brasil), bastante rígida e de cor escura - a qual não deixava em evidência os fios e/ou retalhos de tecidos dentro dos compósitos, foi utilizada em substituição a resina epóxi flexível BVR 222 (Bonivitta, Brasil) e o endurecedor BVE 0101 (Bonivitta, Brasil) (Figuras 4.12.a a 4.12.e)

Seu aspecto cristalino também contribuiu para o quesito estético diferentemente da resina laminada de poliéster, fazendo com que os retalhos ficassem bastante visíveis e criassem efeitos visuais atraentes (Figura 4.12.f). Contudo, as amostras ficaram relativamente espessas e não foi possível testalas num ensaio de tração.

\subsubsection{Utilização de Resina Epóxi e Retalhos de Poliéster: Testes Preliminares no Dinamômetro}

Novamente, a resina utilizada foi a BVR 222 (Bonivitta, Brasil) da qual foram utilizados $60 \mathrm{ml}$ juntamente com 30ml do endurecedor BVE 0101 (Bonivitta, Brasil) (Figura 4.13.a)

Foram usados tecidos $100 \%$ de poliéster de cores diversas obtidos do descarte de uma confecção situada no bairro do Bom Retiro - SP, conforme item 3.1.1 de do capítulo Material e Métodos (Figura 3.1 e Figura 4.13.b). 


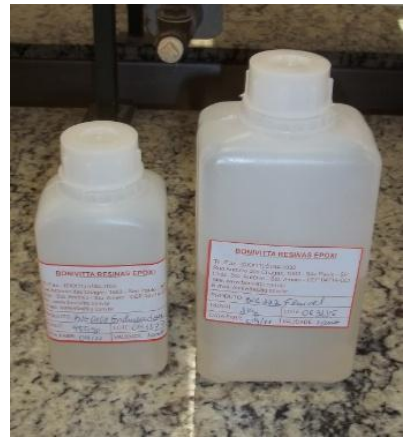

(a)

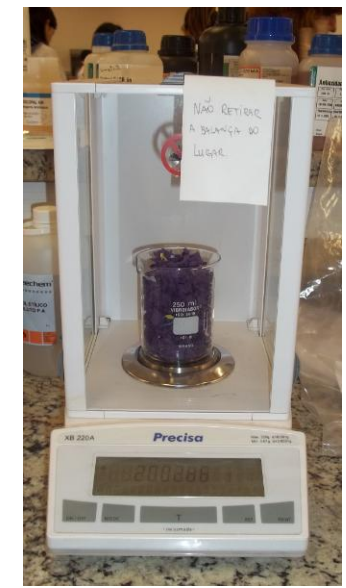

(c)

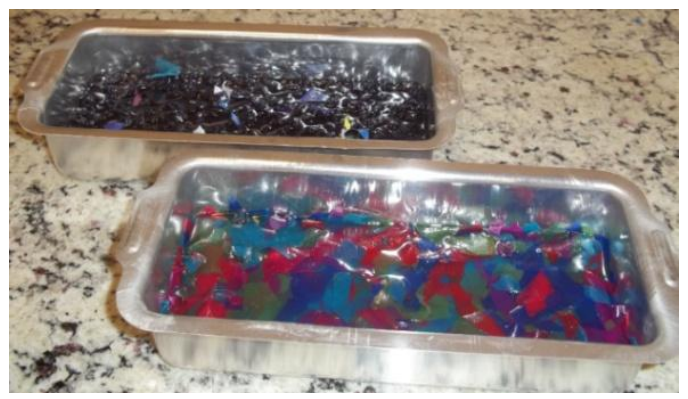

(e)

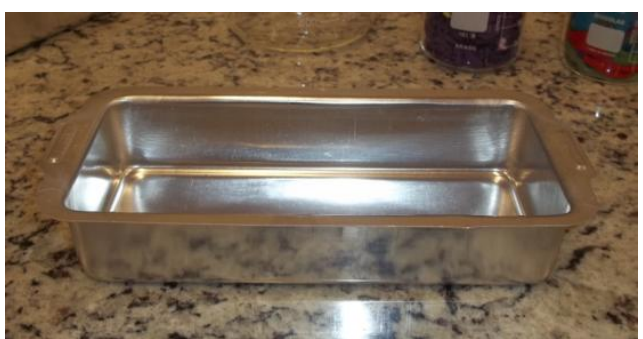

(b)

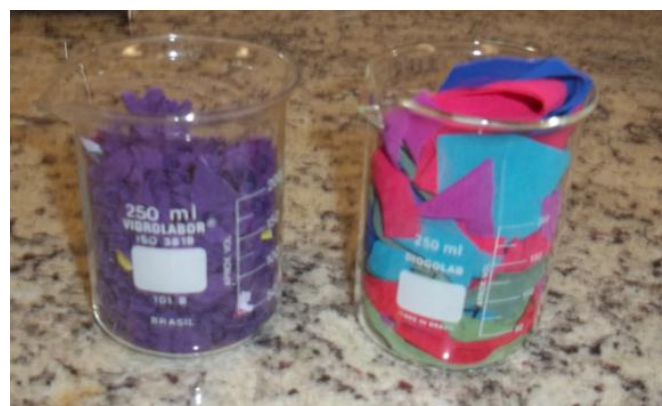

(d)

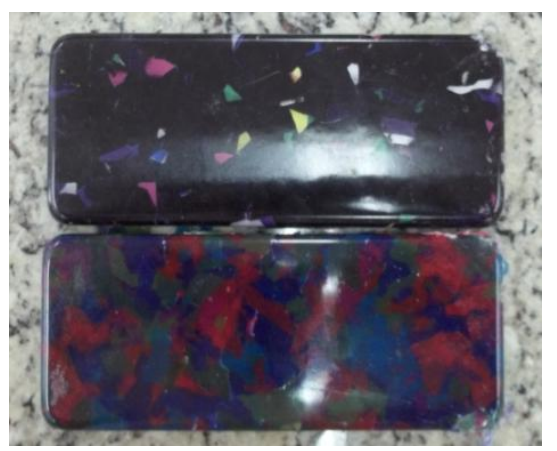

(f)

Figura 4.12. Metodologia desenvolvida para compósitos feitos com resina epóxi: a) resina epóxi flexível BVR 222 e endurecedor BVE 0101 (Bonivitta, Brasil); b) forma de alumínio (Roldan, Brasil); (c) com a balança analítica (Precisa, modelo XB 220A, Suíça) foram pesados aparas de algodão e aparas de poliéster, separadamente (d) retalhos de tecidos já pesados; (e) os retalhos de tecidos foram dispostos na forma e embebidos homogeneamente com a mistura de resina e endurecedor; (f) compósito feito com retalhos e resina epóxi flexível (Fotos do autor, 20/09/2011) 


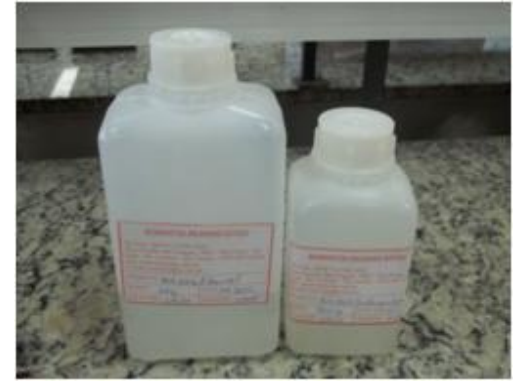

(a)

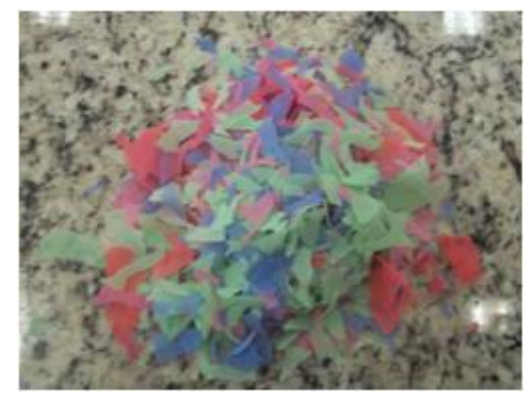

(c)

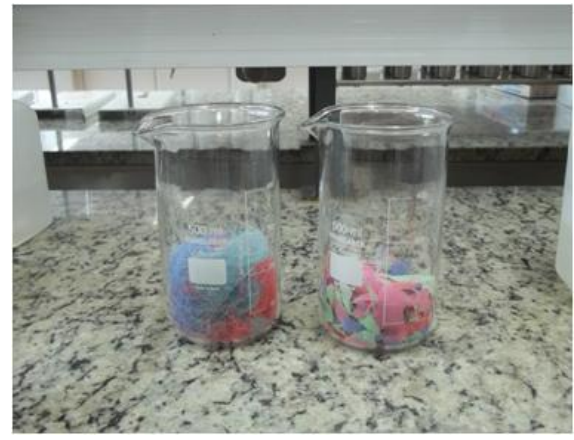

(e)

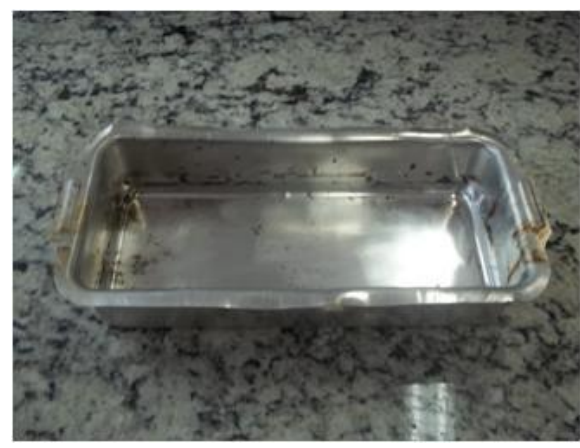

(g)

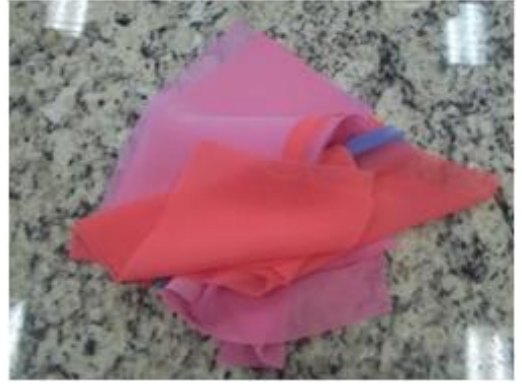

(b)

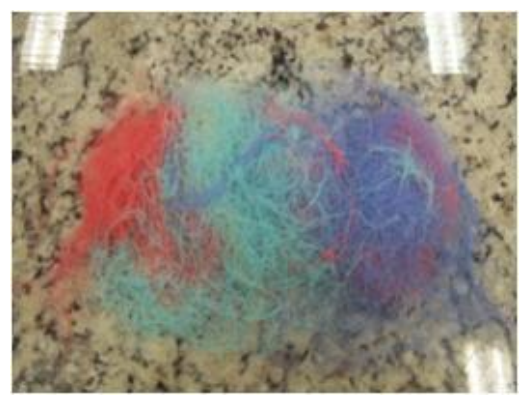

(d)

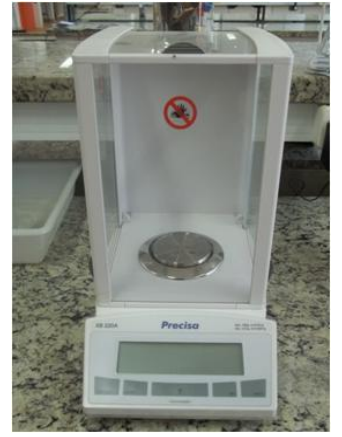

(f)

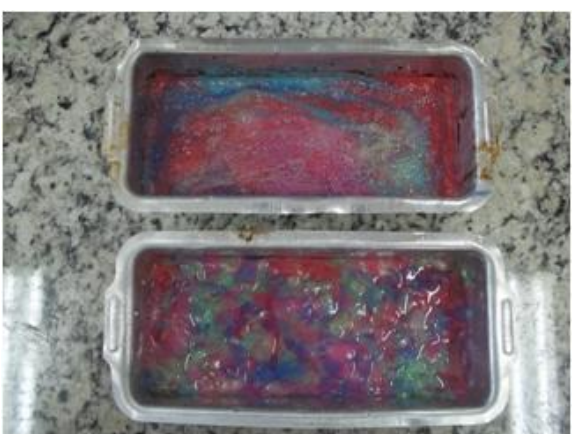

(h)

Figura 4.13. Metodologia de desenvolvimento de um compósito têxtil: (a) Resina BVR 222 endurecedor BVE 0101(Bonivitta, Brasil); (b) retalhos de tecidos $100 \%$ poliéster; (c) retalhos cortados na tesoura; (d) tecido desfibrado manualmente; (e) amostras de retalhos e desfibrados separados em béqueres; (f) balança analítica (Precisa, modelo XB 220 A, Suíça); (g) forma de alumínio (Roldan, Brasil) usada como padrão, de $4 \mathrm{~cm}$ de altura, $21 \mathrm{~cm}$ de comprimento e $9 \mathrm{~cm}$ de profundidade; (h) resultado final da mistura entre as fibras têxteis e resina epóxi (Fotos do autor, 20/02/2012) 
Após o endurecimento, os compósitos foram fatiados com o auxílio de uma tesoura caseira e de um estilete por ser tratar de um material extremamente flexível e foi realizado o ensaio de alongamento e tração no dinamômetro da marca Instron (modelo 5569, Norwood, Estados Unidos), conforme descrito no item 3.4.1 de Material e Métodos.

Para cada teste foram utilizadas 4 (quatro) amostras de compósitos com reforço de aparas têxteis (Figura 4.14.g) e 4 (quatro) amostras de compósitos com reforço de fios têxteis (Figura 4.14.h).

Foram determinadas a tenacidade (capacidade que o material tem de absorver energia antes de fraturar) e a extensão até a ruptura e módulo de Young (o qual proporciona uma medida de rigidez do material) (Figuras 4.14a a 4.14h).

Com esses ensaios, conseguiu-se definir a metodologia de trabalho e calibrar o dinamômetro para os demais testes finais que foram realizados posteriormente com os resíduos oriundos da fibra de algodão.

Os resultados foram expressos em média e desvio-padrão, sendo:

i) tenacidade de $0,4 \pm 0,2 \mathrm{MPa}$, módulo de Young de 0,7 $\pm 0,2 \mathrm{MPa}$ e extensão de $22 \pm 5 \mathrm{~mm}$ para os compósitos com reforço de aparas;

ii) tenacidade de 0,7 $\pm 0,2 \mathrm{MPa}$, módulo de Young de 1,0 $\pm 0,2 \mathrm{MPa}$ e extensão de $24 \pm 5 \mathrm{~mm}$ para os compósitos com reforço de fios.

A título de comparação, a Tabela 4.4 expressa valores aproximados de tenacidade e do módulo de Young para alguns materiais. 


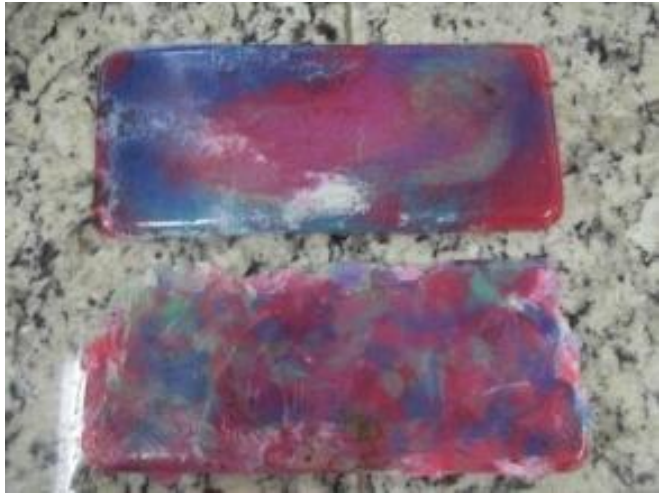

(a)

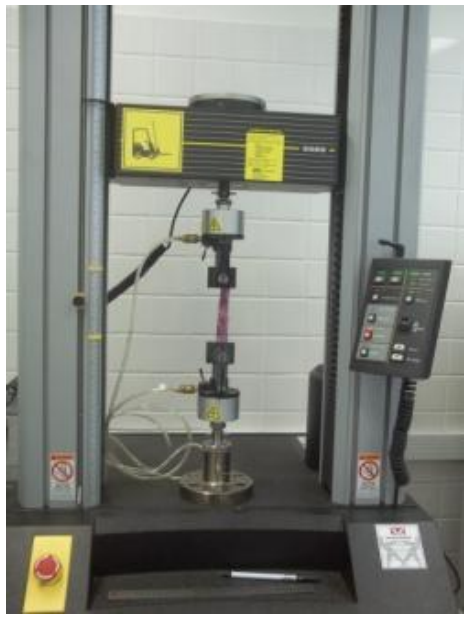

(c)
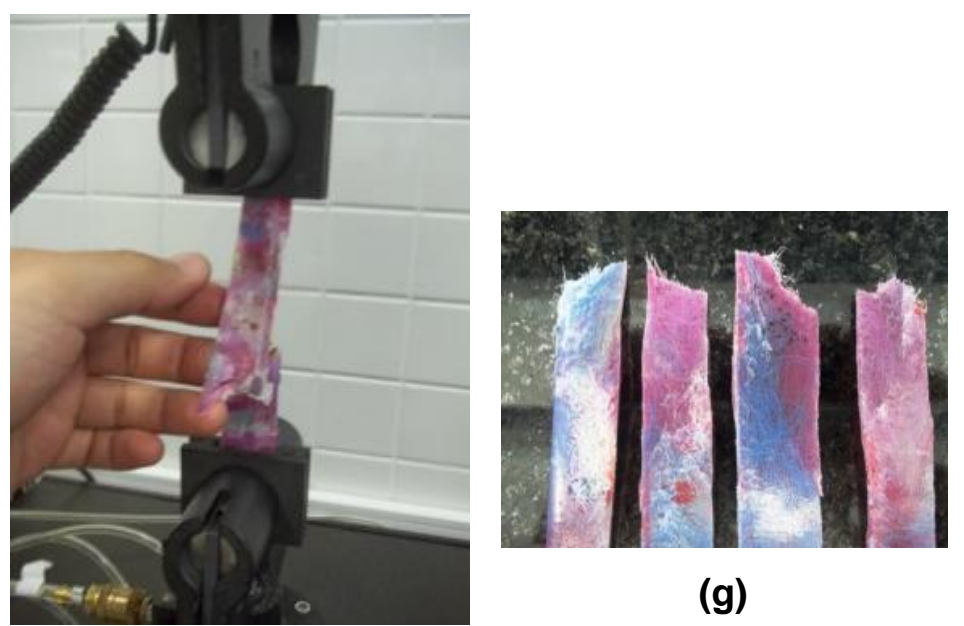

(g)

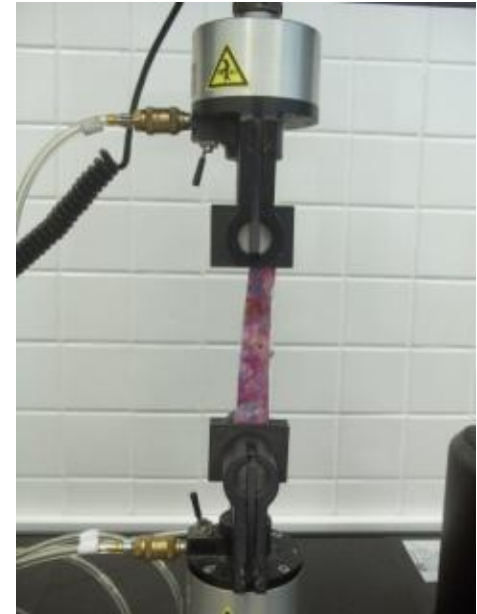

(d)

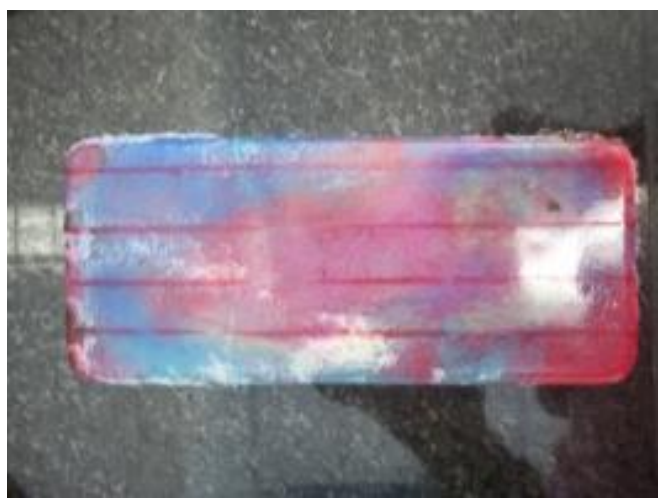

(b)

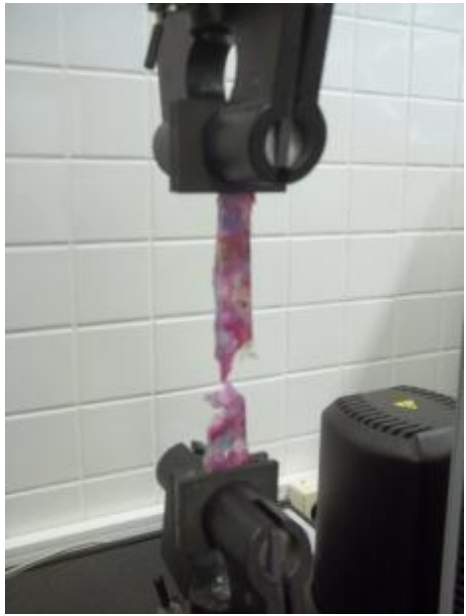

(e)

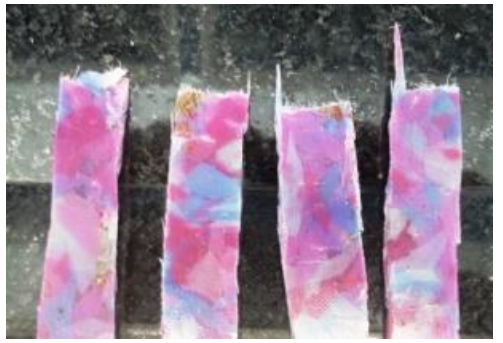

(h)

(f)

Figura 4.14. Metodologia para testes de tração: (a) compósitos feitos com aparas de tecidos, fios e resina epóxi; (b) as placas de compósitos foram medidas e fatiadas, tendo $2 \mathrm{~cm}$ de largura, $10 \mathrm{~cm}$ de altura e aproximadamente mm de espessura; (c) dinamômetro da marca Instron, (modelo 5569, Norwood, Estados Unidos); (d) amostra de compósito sendo tracionada no dinamômetro; (e) ruptura da amostra de compósito após determinada força de tração; (f) amostra de compósito após sua ruptura; (g) amostras de compósitos reforçados com fios; (h) amostras de compósitos reforçados com retalhos (Fotos do autor, 20/02/2012) 
Tabela 4.4. Valores aproximados de tenacidade $\left(\sigma_{p}\right)$ e do módulo de Young $(E)$ para alguns materiais (RESMAT, 2012).

\begin{tabular}{lcc|c|cc}
\cline { 4 - 6 } Material & Acrílico & Aço médio & Borracha & Cobre & Duralumínio \\
\hline$\sigma_{\mathrm{p}}(\mathrm{MPa})$ & 14 & 310 & 2 & 28 & 124 \\
$\mathrm{E}(\mathrm{MPa})$ & 3.400 & 206.000 & 1 & 118.000 & 72.000 \\
\hline
\end{tabular}

Pelos valores obtidos para os compósitos produzidos e os apresentados, nota-se que as amostras testadas possuem tenacidade e módulo de Young semelhantes aos da borracha por ter se tratar de um produto feito com resina flexível. Portanto, a aplicação deste tipo de material seria destinada à área de moda e decoração e teria o aspecto estético, para este tipo de material, como característica mais relevante do que suas propriedades mecânicas - no que diz respeito à resistência.

Verificou-se também que as amostras feitas com resina e aparas eram menos resistentes que amostras feitas de resina e fios, concluindo que os compósitos fibrosos possuem maior ancoragem (coesão entre as interfaces) e, consequentemente, maior resistência.

\subsection{Ensaios Finais com Resinas Epóxi, de Poliéster e de Poliuretano}

O ideal seria o emprego de resinas biodegradáveis, mas não foi possível utilizá-las em virtude da inexistência de empresas que fornecessem tal material em pequenas quantidades. Logo, foram utilizadas resinas não-biodegradáveis como matrizes para a produção de compósitos em caráter de protótipos em pequena escala. Assim, foram utilizadas as resinas epóxi, de poliéster e de poliuretano (Figura 4.15), com características técnicas já descritas nos itens

\subsubsection{1 a 4.1.5.3.}

Através de ensaios no dinamômetro, foram determinadas as médias, desvios-padrão e coeficientes de variação dos valores de carga máxima $(\mathrm{N})$, tenacidade máxima (MPa), extensão na carga de ruptura $(\mathrm{mm})$ e módulo de Young (MPa). 
Os principais resultados são apresentados na Tabela 4.5:

Tabela 4.5. Resultados obtidos em dinamômetro com as resinas epóxi, de poliéster e de poliuretano puras e reforçadas com fibras de algodão provenientes de tecido denim. Os valores estão expressos em média e desviopadrão e, em parênteses, se encontram os valores dos coeficientes de variação.

\begin{tabular}{|c|c|c|c|c|c|}
\hline & Amostras & $\begin{array}{l}\text { Carga } \\
\text { Máxima } \\
\text { (N) }\end{array}$ & $\begin{array}{l}\text { Tenacidade } \\
\text { Máxima } \\
\text { (MPa) }\end{array}$ & $\begin{array}{c}\text { Extensão } \\
\text { de } \\
\text { Ruptura } \\
(\mathbf{m m}) \\
\end{array}$ & $\begin{array}{l}\text { Módulo } \\
\text { (MPa) }\end{array}$ \\
\hline $\begin{array}{l}\text { Resina Époxi } \\
\text { pura }\end{array}$ & 3 & $\begin{array}{c}9 \pm 1 \\
(11 \%)\end{array}$ & $\begin{array}{c}0,09 \pm 0,01 \\
(11 \%)\end{array}$ & $\begin{array}{l}35 \pm 4 \\
(11 \%)\end{array}$ & $\begin{array}{c}0,5 \pm 0,1 \\
(23 \%)\end{array}$ \\
\hline $\begin{array}{l}\text { Resina Époxi com } \\
\text { fibras de algodão }\end{array}$ & 5 & $\begin{array}{l}17 \pm 1 \\
(7 \%) \\
\end{array}$ & $\begin{array}{c}0,16 \pm 0,01 \\
(7 \%)\end{array}$ & $\begin{array}{l}21 \pm 4 \\
(17 \%) \\
\end{array}$ & $\begin{array}{c}1,2 \pm 0,2 \\
(13 \%) \\
\end{array}$ \\
\hline $\begin{array}{c}\text { Resina Poliéster } \\
\text { pura }\end{array}$ & 5 & $\begin{array}{c}654 \pm 58 \\
(9 \%)\end{array}$ & $\begin{array}{c}6,5 \pm 0,6 \\
(9 \%)\end{array}$ & $\begin{array}{c}5,6 \pm 0,4 \\
(7 \%)\end{array}$ & $\begin{array}{c}193 \pm 19 \\
(10 \%)\end{array}$ \\
\hline $\begin{array}{c}\text { Resina Poliéster } \\
\text { com fibras de } \\
\text { algodão }\end{array}$ & 5 & $\begin{array}{c}1.379 \pm 72 \\
(5 \%)\end{array}$ & $\begin{array}{c}13,8 \pm 0,7 \\
(5 \%)\end{array}$ & $\begin{array}{c}2,7 \pm 0,3 \\
(10 \%)\end{array}$ & $\begin{array}{c}772 \pm 120 \\
(16 \%)\end{array}$ \\
\hline $\begin{array}{c}\text { Resina } \\
\text { Poliuretano pura }\end{array}$ & 5 & $\begin{array}{c}1.607 \pm 408 \\
(25 \%)\end{array}$ & $\begin{array}{l}16 \pm 4 \\
(25 \%)\end{array}$ & $\begin{array}{c}3,6 \pm 0,5 \\
(15 \%)\end{array}$ & $\begin{array}{c}679 \pm 152 \\
(22 \%)\end{array}$ \\
\hline $\begin{array}{c}\text { Resina } \\
\text { Poliuretano com } \\
\text { fibras de algodão }\end{array}$ & 5 & $\begin{array}{c}1.618 \pm 427 \\
(26 \%)\end{array}$ & $\begin{array}{c}16 \pm 4 \\
(26 \%)\end{array}$ & $\begin{array}{l}4 \pm 0,8 \\
(20 \%)\end{array}$ & $\begin{array}{c}702 \pm 225 \\
(32 \%)\end{array}$ \\
\hline
\end{tabular}

Comparativamente com diversos materiais compósitos produzidos (Tabela 4.5) e com relação aos encontrados em literatura (Tabela 4.4 e 4.5), os compósitos produzidos no presente trabalho com resina époxi apresentam módulos compatíveis com os da borracha, tais quais os dos testes preliminares do item anterior (4.2.3), mas menores (da ordem de 1000 vezes menor) do que os de materiais poliméricos usualmente empregados em aplicações de engenharia (Tabela 4.6).

Com relação aos compósitos produzidos com resinas de poliéster ortoftálico e poliuretano, os valores dos módulos são de ordem de grandeza compatível, ainda que inferiores aos dos materiais poliméricos apresentados na Tabela 4.6. Por exemplo, com relação aos valores mínimos de módulo do náilon $(1.590 \mathrm{MPa})$, os valores obtidos variam de um mínimo de 10 vezes menor (para a resina poliéster ortoftálico pura) até 2 vezes menor (caso das resinas poliéster com fibras de algodão, poliuretano pura e poliuretano com fibras de algodão). 


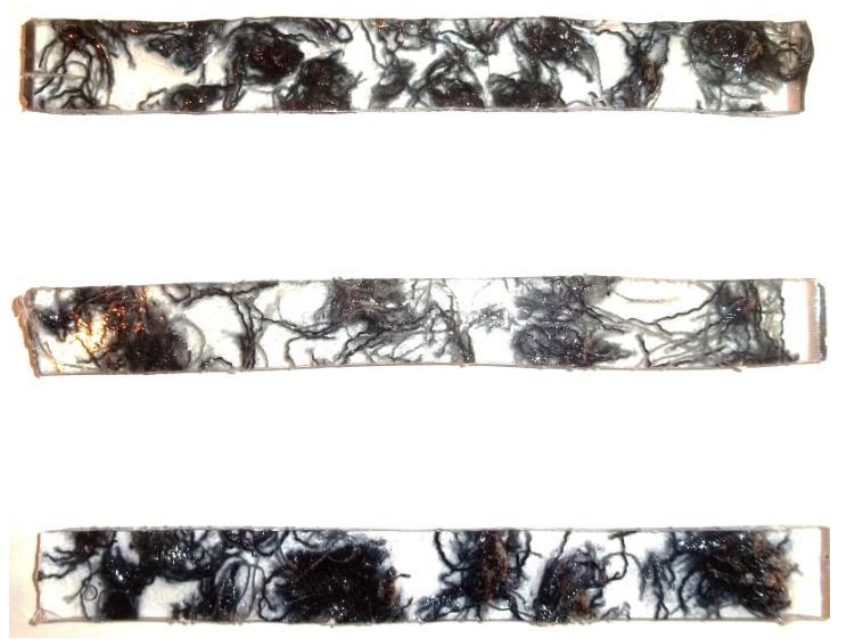

Figura 4.15. Corpos de prova de compósitos produzidos com fibras de algodão de tecido denim. De cima para baixo: compósito de resina époxi, de resina de poliéster ortoftálico e de resina de poliuretano (Fotos do autor, 08/12/12)

Tabela 4.6. Comparação de resistências (Módulo de Young) entre diferentes materiais (CALLISTER 2007 apud COSSOLINO; PEREIRA, 2010)

\begin{tabular}{|c|c|c|}
\hline Classe & Material & Módulo de Young (MPa) \\
\hline \multirow[t]{6}{*}{ Metais } & Aço & 207.000 \\
\hline & Cobre & 110.000 \\
\hline & Latão & 97.000 \\
\hline & Alumínio & 69.000 \\
\hline & Estanho & 44.300 \\
\hline & Chumbo & 13.500 \\
\hline \multirow[t]{6}{*}{ Polímeros ${ }^{1}$} & Polietileno & $2.460-4.140$ \\
\hline & Cloreto de polivinila & $2.410-4.140$ \\
\hline & Épóxi ${ }^{2}$ & 2.410 \\
\hline & Policarbonato & 2.380 \\
\hline & Poliéster $^{3}$ & $2.040-4.410$ \\
\hline & Náilon & $1.590-3.790$ \\
\hline \multirow[t]{6}{*}{ Cerâmicas } & Diamante (sintético) & $800.000-925.000$ \\
\hline & Óxido de alumínio ( $99,9 \%$ de pureza) & 380.000 \\
\hline & Nitreto de Silício (sinterizado) & 304.000 \\
\hline & Vidro de sílica, cal e soda & 69.000 \\
\hline & Concreto civil ${ }^{4}$ & $25.400-36.600$ \\
\hline & Grafita (extrudada) & 11.000 \\
\hline
\end{tabular}

${ }^{1}$ Plásticos de engenharia, ${ }^{2}$ Plástico de engenharia; ${ }^{3}$ Polietileno tereftálato; ${ }^{4} \mathrm{~A} 25 \%$ do limite de resistência à ruptura.

Após alguns ensaios preliminares em relação ao uso de materiais e aos testes mecânicos, optou-se por utilizar as resinas epóxi, de poliéster ortoftálico e de poliuretano juntamente com resíduos têxteis oriundos da fibra de algodão 
em substituição à uma resina biodegradável, de difícil obtenção no mercado nacional.

Foram feitos 20 ensaios de cada tipo de resina, 10 amostras com resina pura e 10 amostras com resina e reforço de resíduos têxteis, totalizando 60 amostras. Contudo, a espessura das amostras foi aproximada em $5 \mathrm{~mm}$ e não exata. Deste modo, algumas "tiras" ficaram mais grossas ou mais finas, influenciando na elasticidade e no ponto de fratura do material e, consequentemente, influenciando também nos resultados finais. Assim, foram escolhidas 5 amostras com resultados menos discrepantes entre si para a elaboração dos gráficos (Apêndice 8.2) e comparação das propriedades dos materiais.

Primeiramente, testaram-se amostras de resina epóxi sem nenhum reforço; para este ensaio, apenas 3 amostras foram utilizadas no resultado final, posto que a resina - extremamente frágil - se deformava com facilidade assim que era presa nas garras do dinamômetro. Contudo, a partir de 3 amostras, é possível ter uma significância estatística de modo a determinar quantitativamente as propriedades do referido material.

Após os ensaios com a resina epóxi pura, foram feitos os testes com os compósitos de resina epóxi reforçados com resíduos de fibra de algodão. Conclui-se que o reforço de resíduos se mostrou eficiente para aumentar a resistência e a tenacidade do material. Assim como na resina epóxi, para as resinas de poliéster e poliuretano, ambas rígidas, também foram utilizadas em amostras puras e amostras reforçadas com resíduos têxteis.

De acordo com a Tabela 4.4, a qual expressa a comparação dos resultados do teste preliminar descrito no item 4.2.3 - onde foi realizado o ensaio de tração dos compósitos produzidos com resina epóxi e reforçados com aparas e com fios de resíduos de poliéster, observa-se que os valores obtidos se assemelham aos da borracha. No entanto, naquele teste preliminar, os valores referentes à tenacidade das amostras são maiores que os valores obtidos nos testes com resina époxi pura e resina époxi reforçada com fibras de algodão. Com relação aos valores de Módulo de Young, os valores foram similares entre os testes efetuados com retalhos e fibras de poliéster e os dos testes finais das amostras de compósitos feitas com resina epóxi reforçadas com fibras de algodão. Possivelmente, os retalhos de tecido e fibras sintéticas 
(poliéster) utilizados nos testes preliminares podem ter tido uma maior aderência com a resina epóxi do que as fibra de algodão. Além disso, foi utilizado um volume maior de resíduos de poliéster nos testes preliminares do que resíduos de fibra de algodão nos testes finais. Ainda, observou-se que depois de retalhados e desfibrados, as aparas e fios de poliéster são mais facilmente acondicionados no fundo dos recipientes no momento do preparo do compósito do que as fibras de algodão, podendo haver gerado uma maior coesão entre a matriz époxi e esses resíduos e, consequente, uma maior interface entre as fases (resina e fibras).

Nos testes finais, as resina epóxi, de poliéster e poliuretano também foram utilizadas em amostras puras e amostras reforçadas com resíduos têxteis de algodão. De acordo com os resultados expressos na Tabela 4.5, em todos os casos constata-se que as resistências de todos os materiais aumentaram com o reforço de resíduos têxteis: no caso dos compósitos feitos com resina epóxi, houve um aumento de aproximadamente 2 vezes em relação à sua resistência e módulo. Para os compósitos de resina de poliéster ortoftálico, aqueles com reforço de fibras se mostraram aproximadamente 2 vezes mais resistentes e com o módulo 3 vezes maior. Apenas para a resina de poliuretano, sem e com o reforço de fibras, não houve uma variação expressiva na resistência e no valor de módulo.

No entanto, observa-se que os valores experimentais de módulo de Young apresentados na Tabela 4.5 são menores do que os valores dos polímeros (plásticos de engenharia) apresentados na Tabela 4.6. Uma hipótese plausível para isto se deve ao fato de que no presente trabalho foram empregadas resinas de uso corrente na área de artesanato e produção customizada de artigos para os quais são exigidas resistências menores do que os empregados corriqueiramente em aplicações de engenharia. No entanto, comparando-se os valores experimentais da Tabela $4.5 \mathrm{com}$ os da Figura 2.30, observa-se que os valores dos módulos das amostras de resina époxi, sem e com reforço de fibras, são compatíveis com os de espumas e borrachas, enquanto que os valores dos módulos das amostras de resina de poliéster ortoftálico e poliuretano, sem e com reforço de fibras, são compatíveis com os do poliuretano e náilon. Deste modo, a aplicação dos compósitos 
produzidos para as áreas de moda ou em outros segmentos do design devem ter o aspecto estético como característica mais relevante do que suas propriedades mecânicas.

A boa aderência (interface) dos dois materiais utilizados - resina e resíduos têxteis - também foi comprovada pelo aumento das resistências e dos valores de módulo de Young mostrados na Tabela 4.5, uma vez que a falta de coesão influi diretamente nas tensões intermateriais e, em alguns casos, os materiais compósitos possuem tendência à formação de vazios e trincas no interior e na superfície de seus componentes (ALMEIDA; REZENDE, 2001).

Na Figura 4.16 é possível comprovar, pelas ampliações feitas no microscópio com aumento de 32 vezes, o local de ruptura dos compósitos, após os testes de dinamômetro, onde se pode observar a boa aderência ou ancoragem entre as matérias primas utilizadas, já que não foram observadas fibras arrancadas de dentro da matriz polimérica, nem tampouco trincas ou fraturas no material compósito como um todo.

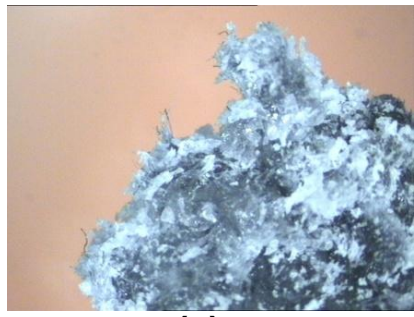

(a)

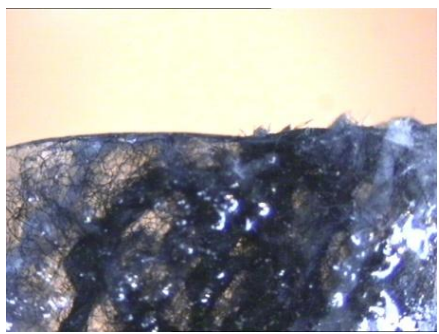

(b)

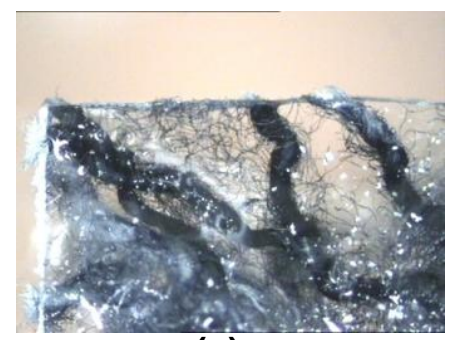

(c)

Figura 4.16. Ampliações de 32 vezes dos compósitos no local de ruptura dos testes de dinamômetro comprovam a boa coesão entre a matriz polimérica e o reforço de resíduos têxteis: (a) compósito de resina epóxi, (b) de resina de poliéster ortoftálico e (c) de resina de poliuretano

A partir desses materiais compósitos produzidos foi possível avaliar preliminarmente suas características e potenciais para aplicações posteriores. Os resultados obtidos no presente trabalho poderão servir como base para outras pesquisas de produção e aplicação de compósitos feitos de resinas poliméricas e fibras têxteis. Em adição, espera-se, em estudos futuros, que seja possível a obtenção de resinas biodegradáveis no mercado nacional. 


\subsection{O Processo Criativo e as Sugestões de Aplicação dos Compósitos na área de Moda}

Para o desenvolvimento de um produto, o designer parte da necessidade de transformação do homem e da sociedade, exigindo observações detalhadas da realidade por meio de sua criatividade (FERRARI, 2011) e de seus "documentos de processo" (SALLES, 2008), que seriam o repertório que o profissional utiliza para o desenvolvimento de seu projeto.

A criatividade, entendida como a interação entre processos cognitivos, características de personalidade e de elementos ambientais, educacionais, sociais e culturais (WECHSLER, 2008), tem o desenho como forma de representação gráfica, no qual se demonstra uma intenção artística ou projetual. Assim, o croqui compreende o registro de um processo em desenvolvimento (FERRARI, 2011).

O designer, além de desenvolver as ideias no papel, também avalia e combina técnicas, métodos, tecnologias, custos, normas técnicas e legais, para atender a todos os requerimentos do projeto de forma compatível com o investimento e necessidades do cliente, bem como analisa e determina quais materiais e processos de fabricação são mais viáveis na produção (LDSM UFRGS, 2012).

Em relação à seleção dos materiais, é fundamental a escolha do mais adequado no desenvolvimento de um projeto e a aceitação do público e o bom desempenho do produto são consequências desta etapa (LDSM - UFRGS, 2012).

A crescente inovação de produtos e de processos de fabricação necessitou de uma grande quantidade de recursos naturais para sua expansão: os atuais padrões de produtividade requerem mudanças de posicionamento diante do novo paradigma ambiental, oportunizando a contribuição do design na concepção de novos produtos e a preocupação de aplicar uma metodologia de inovação sustentável, utilizando uma visão tríplice de reunir crescimento econômico, qualidade ambiental e igualdade social (LDSM - UFRGS, 2012).

O presente trabalho visou contribuir com uma proposta de metodologia de projeto de produto pelo viés do eco-design baseado no reuso dos resíduos têxteis, extremamente abundantes segundo a Loga (2011), sugerindo uma 
destinação mais correta do descarte têxtil. Neste estudo, resíduos têxteis foram utilizados como reforço em compósitos de matrizes termorrígidas (resinas cristalinas).

Alguns designers renomados, como os irmãos Campana e o carioca $\mathrm{R}$. Sobral, utilizam ou já se utilizaram de refugos têxteis, entre outros, e de resinas para comporem suas peças. Eles serviram de referência para a presente proposta de metodologia projetual do produto.

Os irmãos Campana fizeram a série de móveis Sushi (2000 - 2004) embasados na utilização de diferentes texturas e tipos de tecidos sobrepostos (IRMÃOS CAMPANA, 2012) (Figura 4.17.a) e o designer Carlos Alberto Rezende Sobral, mais conhecido como R. Sobral, famoso por utilizar diferentes tipos de resinas em suas criações de bijuterias (R. SOBRAL, 2012) (Figura 4.17.b).

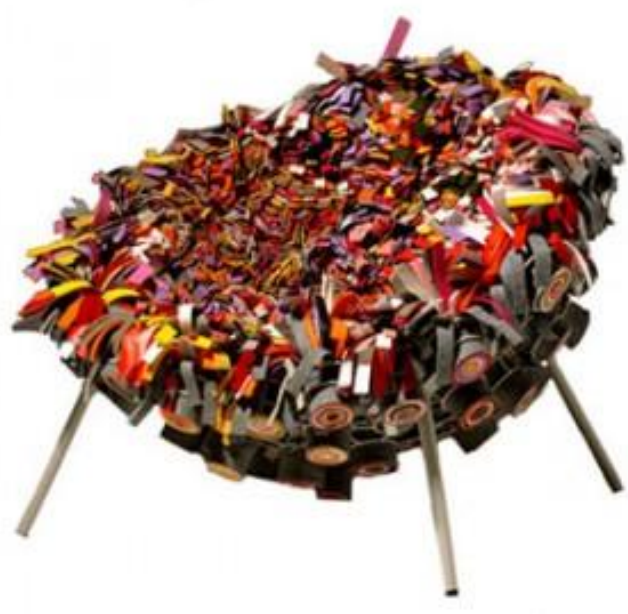

(a)

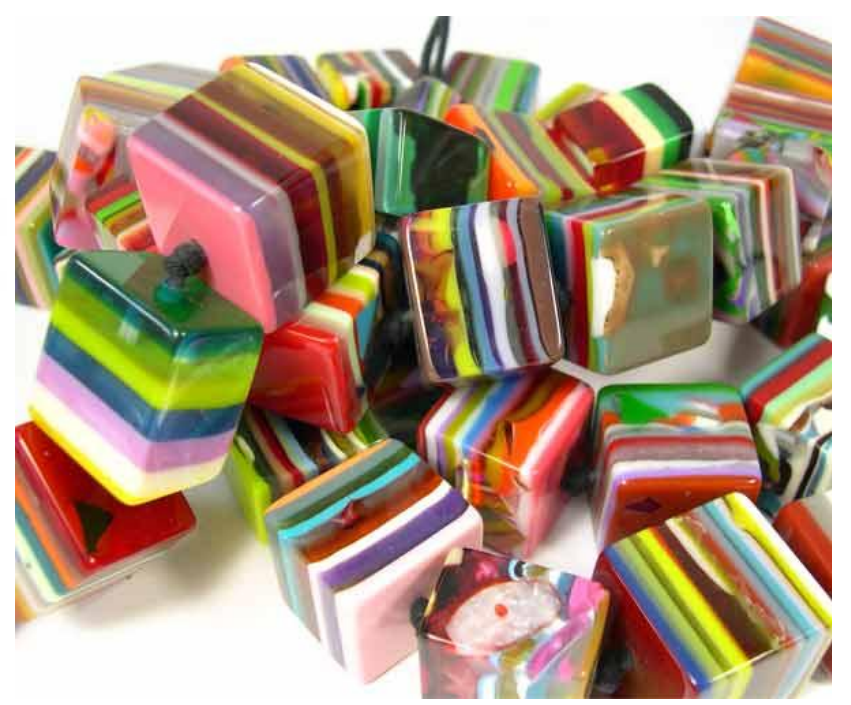

(b)

Figura 4.17. Diferentes inspirações entre têxteis e resinas: (a) poltrona da série Sushi dos irmãos Campana (IRMÃOS CAMPANA, 2012); (b) colar de resina do designer de bijuterias R. Sobral (R. SOBRAL, 2012)

Deste modo, foram desenvolvidos croquis envolvendo possibilidades de criação e utilizações dos compósitos na área de moda, compondo acessórios e utilitários e visando demonstrar, principalmente, seus atributos estéticos (Figuras 4.18 a 4.21 ): 

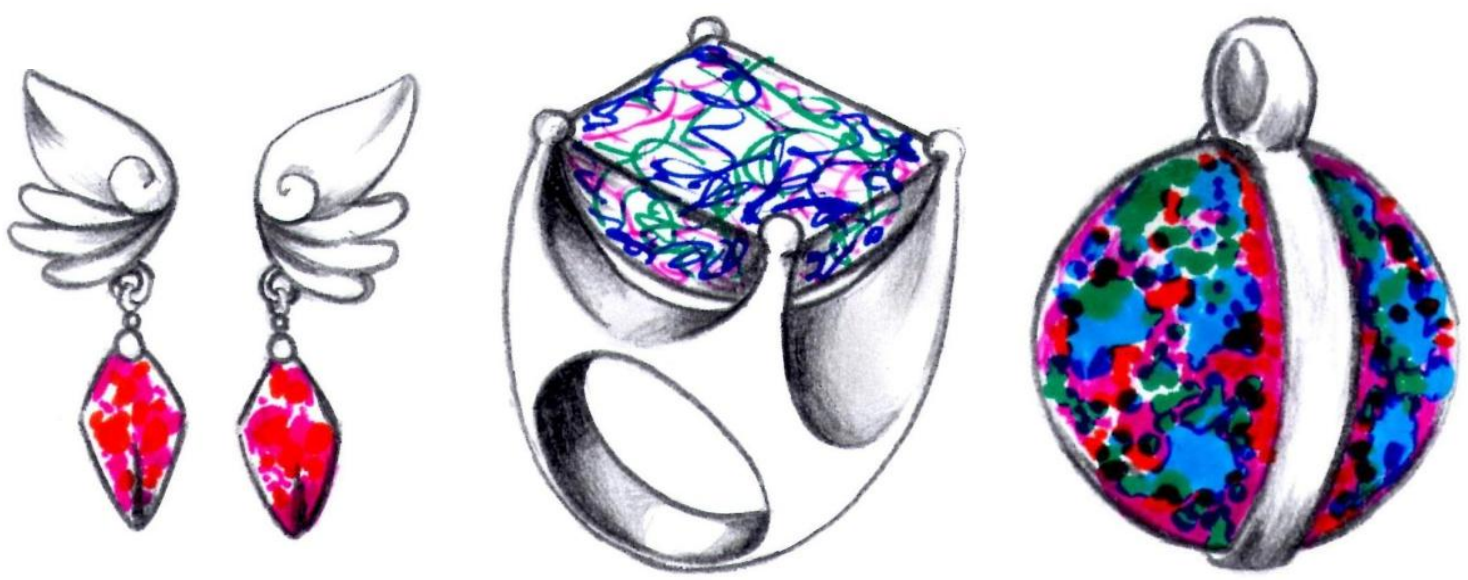

Figura 4.18. Bijuterias feitas com compósitos têxteis - resina rígida ou flexível e reforço com fibras (llustrações do autor, 08/09/2012)
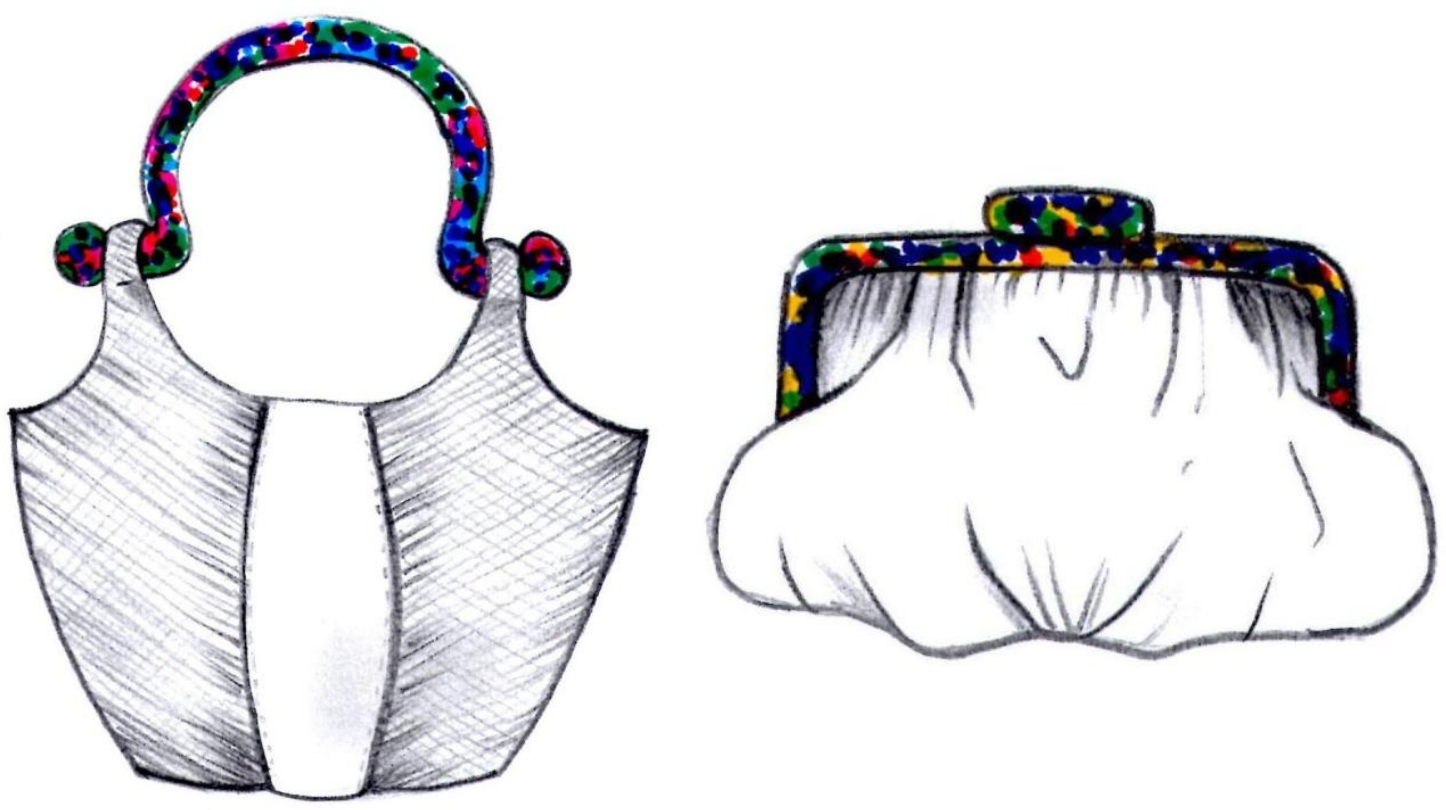

Figura 4.19. Alças e fechos de bolsas feitas com compósitos têxteis - resina rígida e reforço com fibras (Ilustrações do autor, 08/09/2012) 

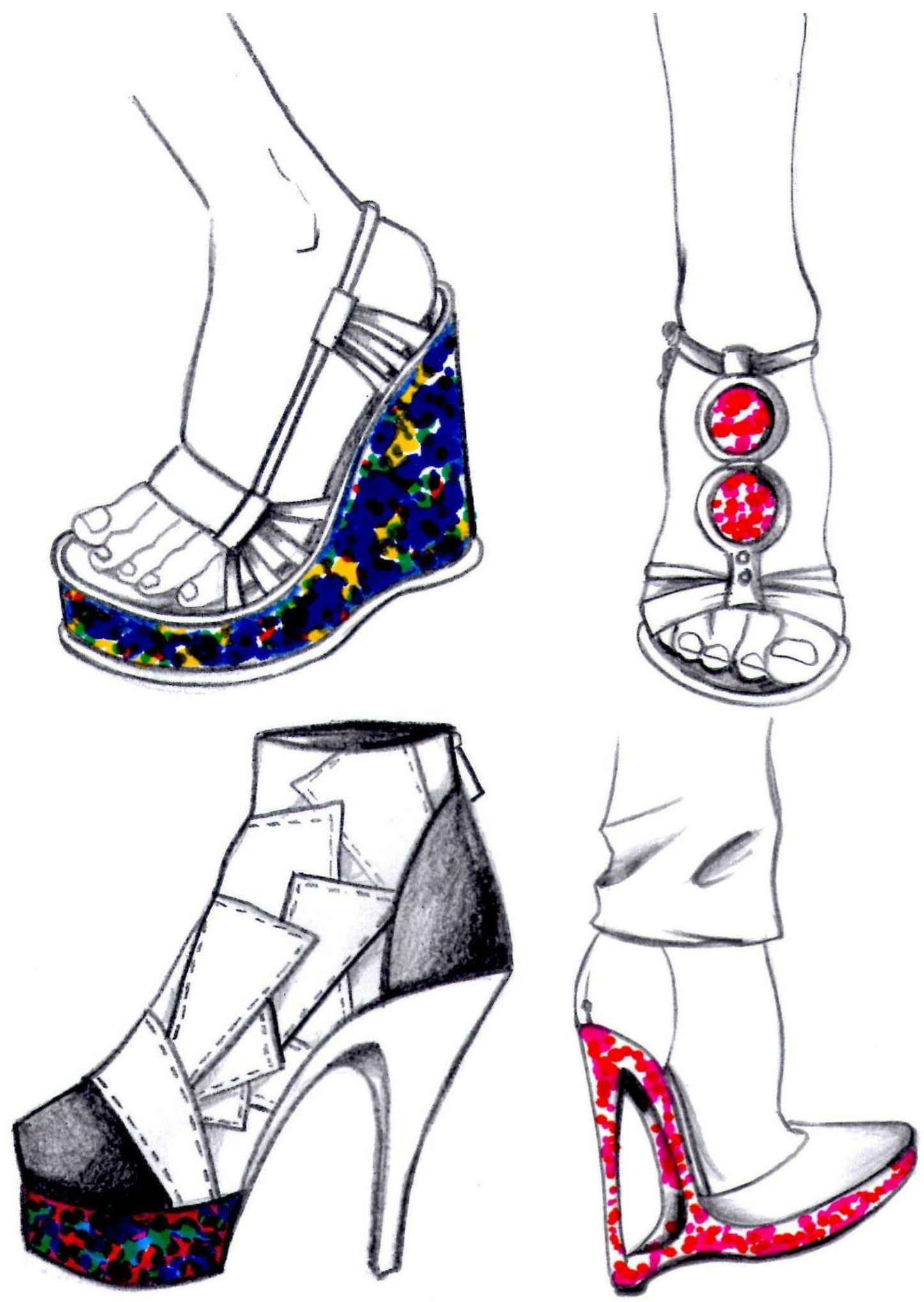

Figura 4.20. Saltos e ornamentos de sapatos feitos com compósitos têxteis resina rígida e reforço com fibras (llustrações do autor, 09/09/2012) 

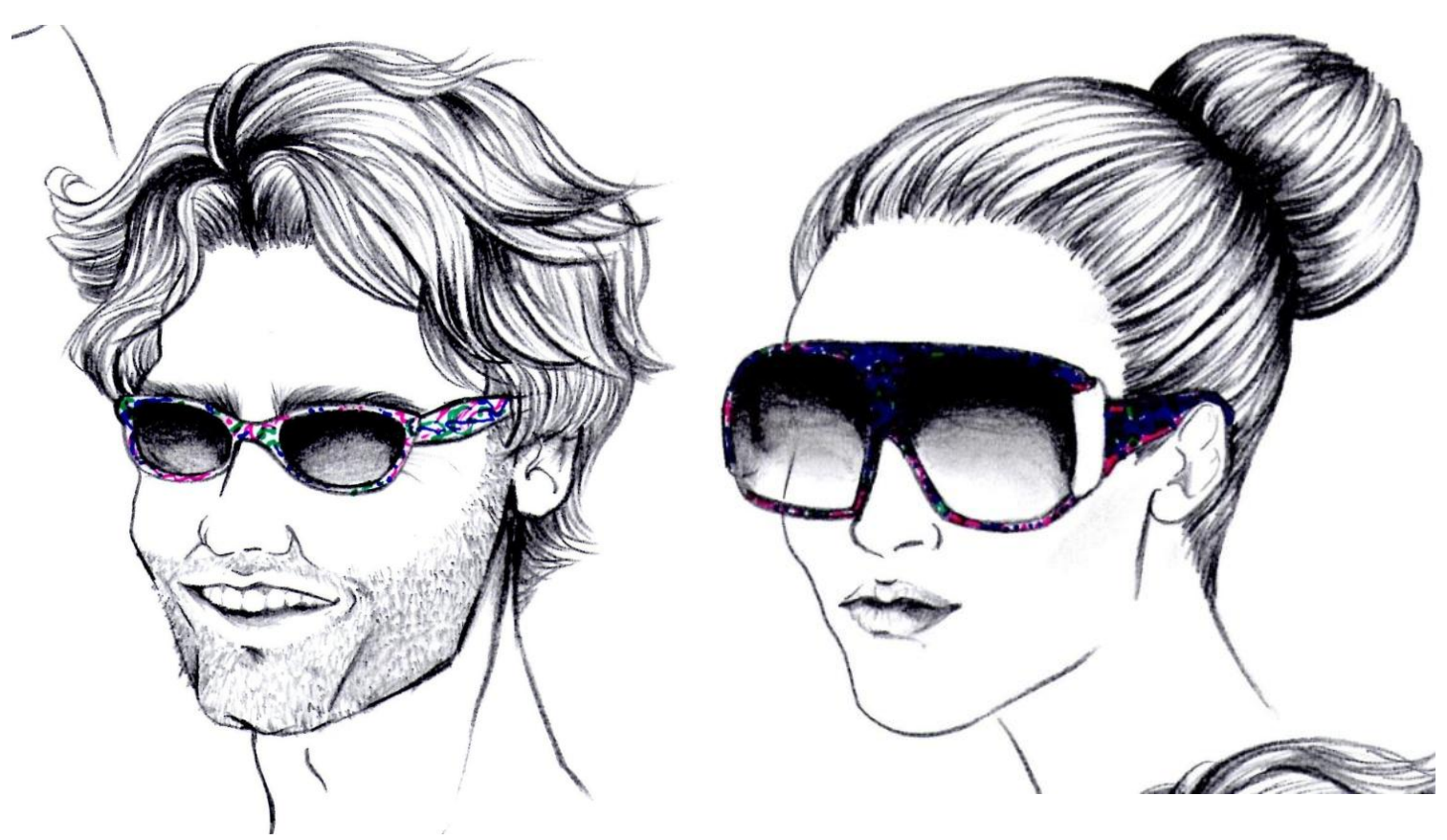

Figura 4.21. Armações de óculos feitas com compósitos têxteis - resina rígida e reforço de fibras (llustrações do autor, 08/09/2012)

Depois de esboçados os croquis no papel, foi feita a parte prática do estudo de desenvolvimento das peças de bijuteria. Os materiais escolhidos foram: refugos têxteis oriundos da fibra de algodão, majoritariamente; refugos oriundos de tecidos de poliéster (Figura 4.22); e resina cristalina epóxi flexível BVR 222 (Bonivitta, Brasil) com o endurecedor BVE 0101 (Bonivitta, Brasil).

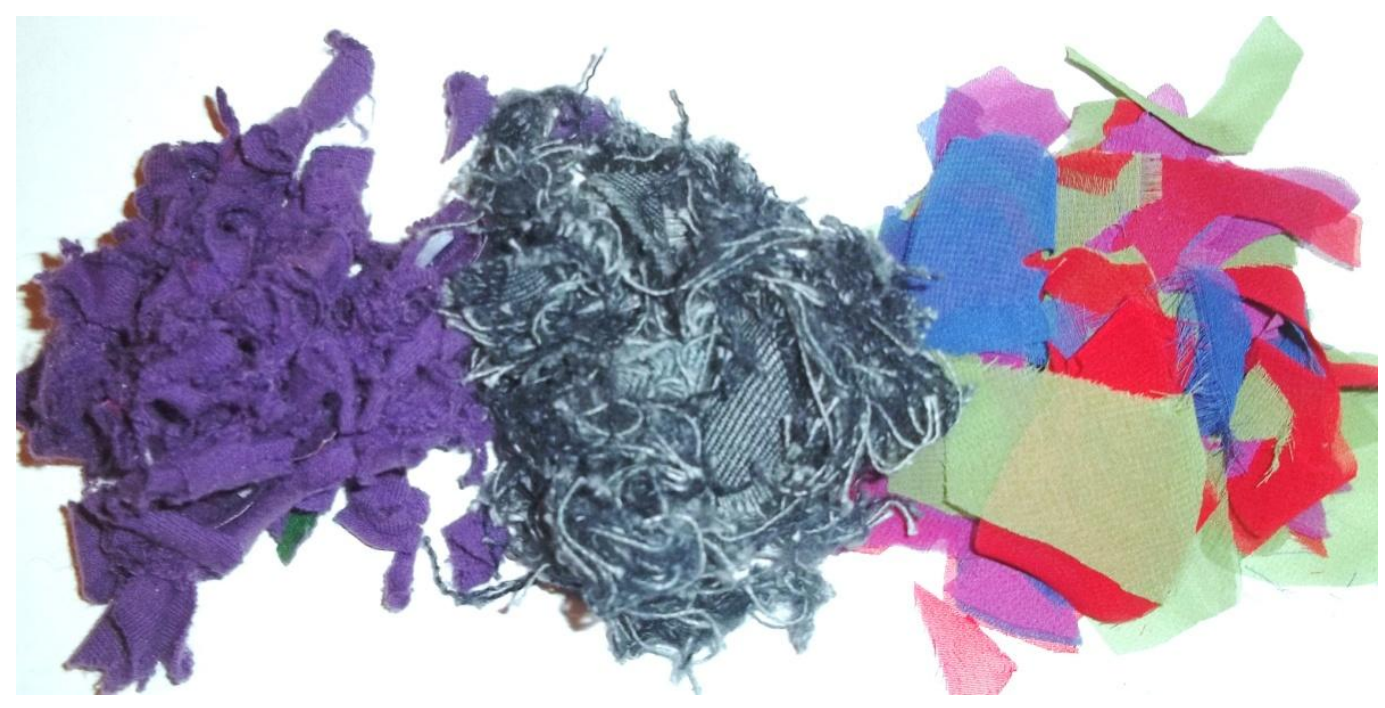

Figura 4.22. Materiais selecionados: resíduos têxteis de origem natural e sintética (foto do autor, 07/12/2012) 
O tipo e volume de resina utilizada, bem como o tipo e volume das fibras utilizadas como reforço, influenciarão nas propriedades de resistência e tenacidade do compósito. Após os testes realizados nos compósitos produzidos, onde foram avaliadas características mecânicas e também visuais do produto, optou-se por criar uma pequena coleção de bijuterias em caráter de protótipos para demonstrar o potencial aplicativo desse material.

Algumas peças de bijuterias e suas "gemas" foram moldadas utilizando uma borracha de silicone (Moldflex, modelo RTV-2, Brasil) e endurecedor (Moldflex, modelo T-Catalyst, Brasil). Depois de prontos e desenformados os moldes em silicone, eles foram preenchidos com resina epóxi e resíduos têxteis conforme descrito no item 3.5 de Material e Métodos.

A partir dos moldes, foram replicadas as peças de bijuterias tendo como principal atributo a estética visual. Confirma-se, sobretudo, que, para qualquer projeto desenvolvido, a escolha dos materiais e processos de fabricação são extremamente importantes, pois influenciam diretamente nas características finais do produto.

Assim, tratando-se de peças mais conceituais utilizadas na área da moda, optou-se pela escolha de uma resina cristalina que deixasse em evidência os refugos têxteis usados internamente como reforços. Optou-se também por misturar diferentes tipos e cores de refugos têxteis como forma de criar efeitos únicos e diversificados inspirados nas obras dos irmãos Campana.

$O$ resultado pode ser conferido a seguir, como apresentado nas Figuras

\subsection{3 a 4.26 .}



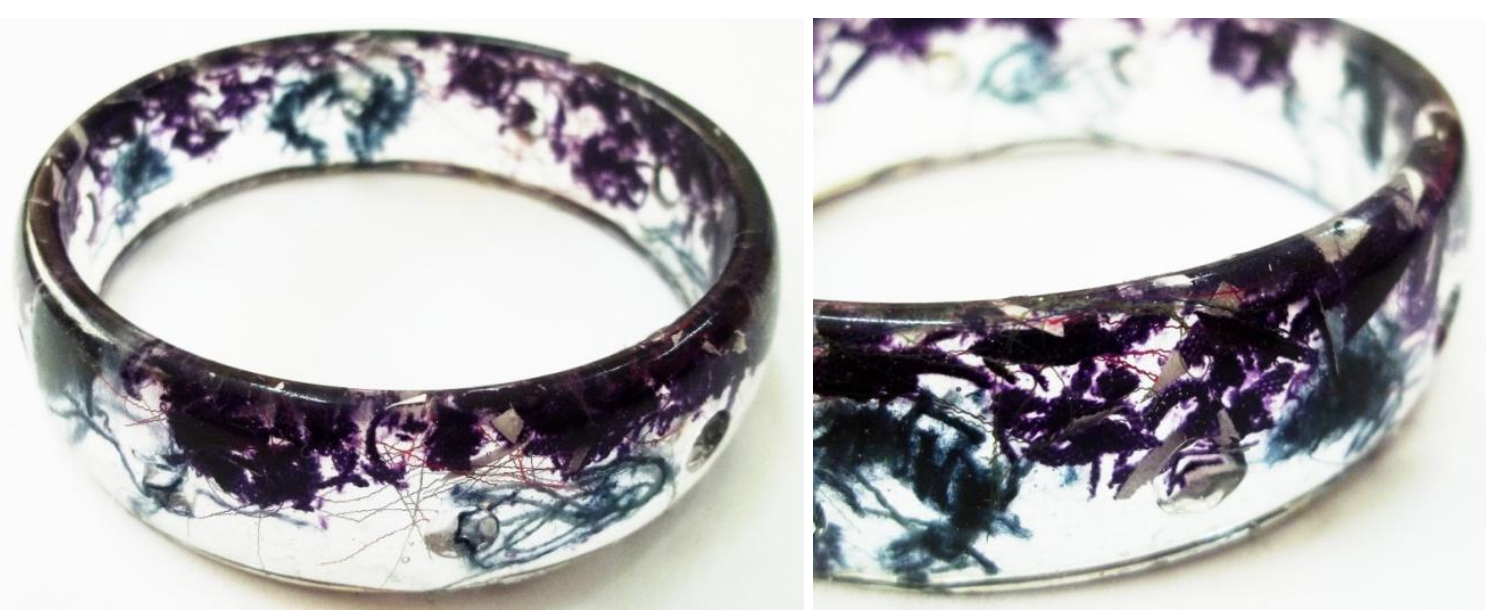

Figura 4.23. Bracelete produzido com resina epóxi e fibras têxteis oriundas dos resíduos da calça jeans e de uma camiseta (fotos do autor, 21/09/2012)
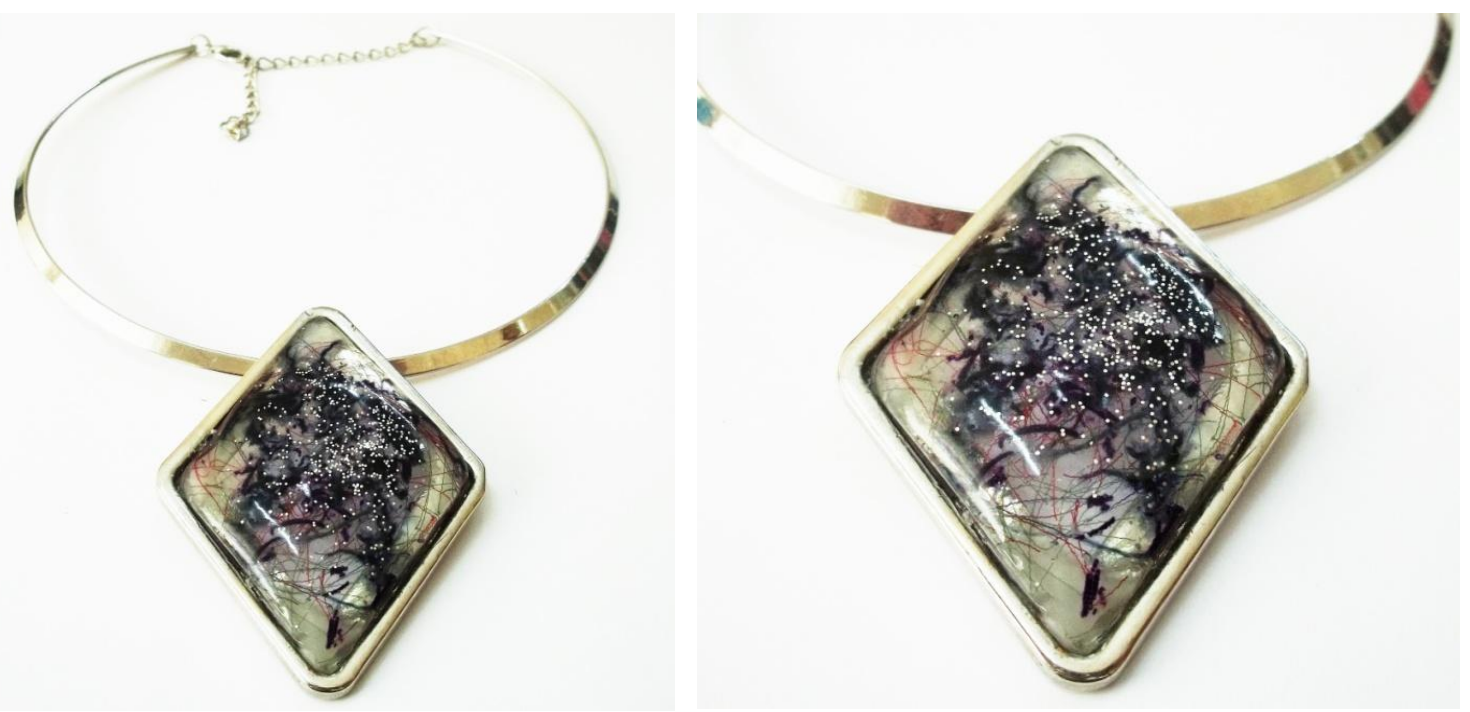

Figura 4.24. Gema de colar produzido com resina epóxi e resíduos têxteis (fotos do autor, 21/09/2012) 

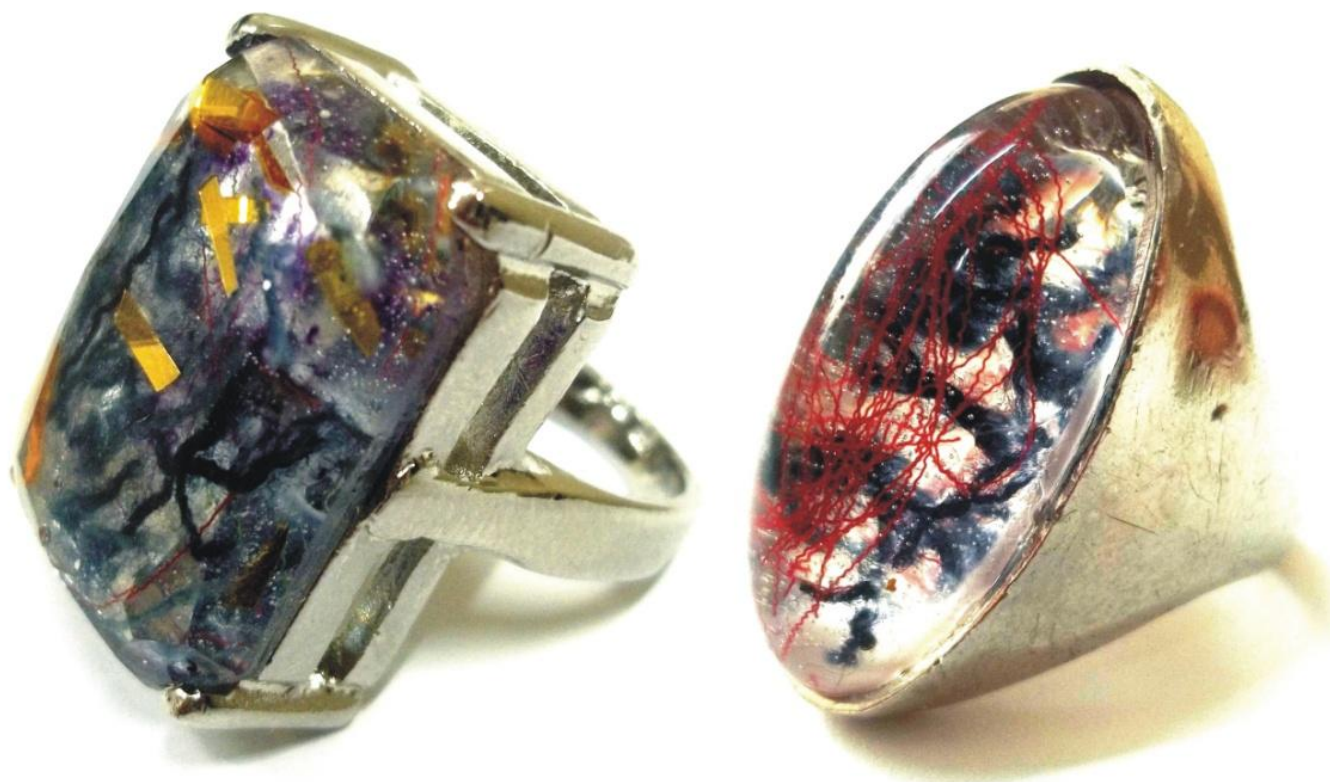

Figura 4.25. Gemas de anéis feitas de compósitos têxteis (fotos do autor, 21/09/2012)

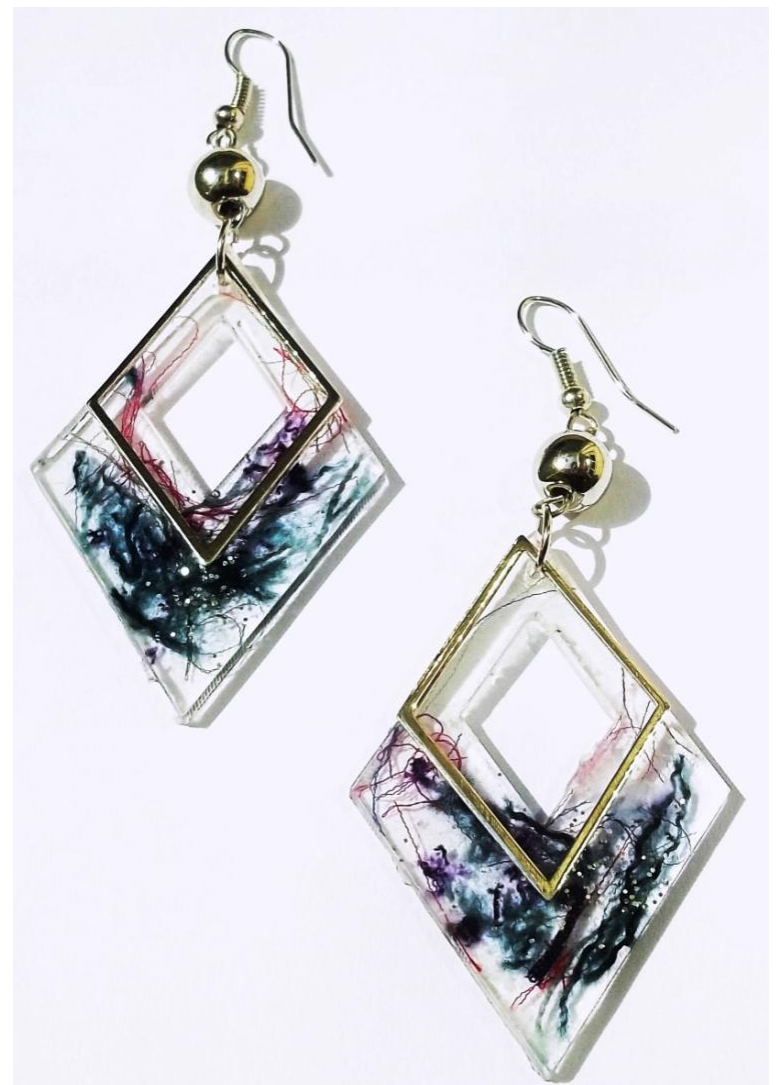

Figura 4.26. Brincos produzidos com resina epóxi e fibras de algodão (fotos do autor, 21/09/2012) 
Assim, conclui-se que os compósitos produzidos além de satisfazerem aspectos técnicos - como aumento da tenacidade e resistência, também contemplam atributos estéticos do material. Visualmente, a mistura da resina cristalina com fibras têxteis resulta num produto final com apelo visual; percebe-se que inúmeras combinações de cores podem ocorrer, além de efeitos diversificados dependendo do tipo de fibra e/ou refugo que se usa. 


\section{CONCLUSÕES}

No presente estudo, após a pesquisa sobre reciclagem e reutilização de fibras oriundas de artigos têxteis, como de conceitos relacionados à ecologia industrial, ao design de moda e ao eco design, aspectos técnicos e de criação sobre os materiais compósitos produzidos, seguem considerações gerais sobre este trabalho como um todo.

A moda, que significa "modo" (LARVER, 1995) e é um conceito originário do século XIX (CALDAS, 1999), se baseia nas mudanças obrigatórias de gosto dos indivíduos (LIPOVETSKY, 1989), que são impulsionadas por propagandas sedutoras em meios de comunicação (DEMETRESCO, 2001) e por movimentos sociais que acontecem nas ruas das grandes cidades, conhecido como o movimento da "moda de rua" (POLHEMUS, 1994).

Para a maioria das pessoas, há um desejo de pertencer a determinado grupo social - e, em contrapartida, de se afastar de outros grupos - e a moda é usada como arma fundamental para isso. As grifes que o indivíduo usa, o modo como se veste e compõe seu look dialogam a todo instante com o mundo que o cerca, passando informações sobre seu comportamento e estilo de vida, que podem ser totalmente reais ou podem corresponder apenas à uma representação ou à uma pequena fração da realidade (SIMMEL, 1989).

Neste âmbito, o do consumo exacerbado e o da ostentação como forma de autoafirmação e de realização pessoal, a produção de vestuário e de acessórios contemplam os desejos de seus consumidores dando a eles, a cada temporada, modos e estilos diferenciados de se vestir, de se sentirem únicos e dando a possibilidade de se inserirem em determinados grupos (ABIT, 2011).

Nos anos 1970, começava-se a falar em ecologia industrial, não exatamente com esta nomenclatura. Com o passar dos anos, os estudos sobre ecologia e tudo o que afeta o meio ambiente foi se intensificando (ARAÚJO et al, 2012). Uma das constatações dos ecologistas e estudiosos do assunto é que a indústria têxtil e da moda são uma das mais poluidoras do mundo, atingindo o meio ambiente em diversos modos: cultivo de monoculturas e uso intenso de pesticidas nas lavouras de algodão, por exemplo, uma das principais fibras têxteis manufaturadas pelo homem; envenenamento do solo e dos lençóis freáticos por meio de pesticidas e outros produtos químicos; uso do 
petróleo, uma fonte não renovável, como matéria-prima dos filamentos (fibras químicas); gasto considerável com energia e água na produção dos fios e tecidos; e uso de corantes tóxicos e outras substâncias químicas usadas no beneficiamento têxtil e que são despejados nos afluentes dos rios indiscriminadamente (ERKMAN et al, 2005).

Não bastasse a produção de têxtil e moda ser bastante agressiva ao meio ambiente, os bens que ela produz são extremamente efêmeros, havendo sua substituição a todo momento, conforme os desejos reais dos indivíduos e a vontade das empresas de moda de criarem novos desejos nessas pessoas (LÖBACH, 2001).

A vida útil de um artigo têxtil pode ser de 3 anos, contudo, havendo a efemeridade como característica fundamental da moda, este tempo pode ser reduzido drasticamente. Além do alto consumo de artigos têxteis fazer com que as indústrias produzam mais - e, na maioria das vezes, sem a competência e consciência ecológica necessárias - 0 uso desses bens também acarretam um impacto ao meio ambiente, uma vez que há a necessidade de manutenção deles (uso de sabão em pó para sua limpeza e posterior descarte das embalagens, uso de água, uso de energia para passadoria, entre outros (WASTE ON LINE, 2011).

Com a alta volatilidade da moda, os artigos têxteis, mesmo os em bom estado, são descartados indiscriminadamente pelos consumidores, ávidos por novidades e produtos recém-lançados no mercado. Estes artigos, bem como os resíduos industriais, se configuram num grande problema ambiental, sugerindo que a reciclagem e a reutilização deles é a melhor saída para a diminuição do lixo nos aterros sanitários (RICKEN; POZZA; TEIXEIRA, 2008).

No Brasil, a reciclagem e a reutilização de têxteis ainda é pouca vista e incentivada, mesmo depois da Lei 12.305 de 02/08/2010 que instituiu a Política Nacional de Resíduos Sólidos (BRASIL, 2011), diferentemente do que ocorre na Inglaterra e em outros países que possuem uma política consolidada de descarte de têxteis (WASTE SAVERS, 2011).

Apesar de ser uma atividade bastante lucrativa, uma vez que a matériaprima (aparas e refugos têxteis de vários tipos) é abundante, muitas toneladas de tecidos ainda são despejados em aterros sanitários aqui no Brasil. Só no bairro do Bom Retiro, em São Paulo, a concessionária Loga (2012) retira 
aproximadamente 16 toneladas de resíduos têxteis por dia e aproximadamente 10 toneladas no bairro do Brás, grandes produtores de vestuário. Observa-se que é um número expressivo e que outros produtos poderiam ser desenvolvidos com a utilização desta matéria-prima.

A fibra de algodão, notadamente a mais consumida no país $-60 \%$ dos artigos têxteis são produzidos com esta matéria-prima (ABIT, 2011), poderia ser reciclada em diferentes fases: dentro do próprio processo industrial (ou seja, cada fiação deveria reciclar seus resíduos industriais, passando-os novamente nos processos de manufatura) ou fora do processo industrial (ou seja, deveria haver uma logística/destino aos resíduos industriais, bem como os resíduos têxteis domésticos, que seriam reprocessados em empresas recicladoras e usados como matéria-prima em outros produtos, como mantas para isolamento térmico e acústico, enchimento de pelúcias e até mesmo como matéria-prima para reforço em compósitos).

Como sugestão para o destino dado aos refugos têxteis, a aplicação dessa matéria-prima em compósitos de matrizes termorrígidas, seria uma solução viável economicamente (por ser um material abundante e barato) e que traria grandes benefícios ao meio-ambiente, como a diminuição do descarte têxtil em aterros sanitários. Os compósitos são materiais feitos com 2 ou mais matérias-primas diferentes que, unidas, foram um composto com características impossíveis de se obter separadamente (CARVALHO, 2005). O desenvolvimento de materiais compósitos utilizando fibras vegetais como reforço é crescente e vêm conquistando novos segmentos de mercado, pois as fibras vegetais apresentam baixo custo, biodegradabilidade e boas propriedades mecânicas, físicas e térmicas adequadas às suas aplicações (COSTA; FUJIYAMA, 2011).

A resistência à tração de um compósito polimérico é determinada por vários fatores, incluindo a diminuição da secção transversal da amostra durante o alongamento e o aumento da resistência devido a orientação das fibras na matriz. Este último é influenciado por vários fatores, como por exemplo, a aderência das interfaces das matérias primas, coesão e preenchimento da matriz pelo material de reforço (PUKÁNSZKY, 1990). No presente estudo, foram utilizados 3 tipos diferentes de resinas: epóxi, poliéster e poliuretano em seus estados puros e reforçados com resíduos têxteis de fibra de algodão. Não 
foram utilizadas resinas biodegradáveis por se tratar de experimentos em pequena escala e por não haver empresas, até o dado momento, que fornecessem tal material em pouca quantidade, enfatizando que, se os compósitos estudados forem feitos em larga escala, sejam produzidos com materiais ecológicos e por meio de processos que atendam as normas ambientais vigentes, deixando tal sugestão para ensaios futuros.

As fibras foram dispostas de modo aleatório na matriz, um dos modos possíveis para a aplicação neste tipo de material. Contudo, mesmo com alguns espaços vazios nos corpos de prova, houve uma boa ancoragem entre as interfaces - uma vez que a análise microscópica demonstrou não haver fios arrancados das matrizes poliméricas, sendo que sua presença determinou no aumento da tenacidade e da resistência dos compósitos feitos com cada uma das 3 resinas utilizadas - epóxi, de poliéster e de poliuretano. Comprova-se, então, que os compósitos reforçados com fibras de algodão tiveram melhorias mecânicas em relação aos corpos de provas constituídos apenas de resinas puras.

Além disso, verificou-se que a utilização dos refugos têxteis em compósitos também contempla atributos estéticos do material. Visualmente, a mistura da resina cristalina com fibras têxteis resulta num produto final de grande apelo visual; percebe-se que inúmeras combinações de cores podem ocorrer, além de efeitos diversificados dependendo do tipo de fibra e/ou refugo que se usa.

Conclui-se que os compósitos produzidos a partir de resíduos têxteis, poderiam trazer benefícios ao meio-ambiente, pois além de possuírem atribuições como resistência e coesão, podem ser destinados à área de moda ou em outros segmentos do design pelos atributos visuais que proporcionam. Assim, são capazes de suprir necessidades específicas de consumo do mercado, ávido por novidades, bem como de suprir a demanda por estudos de novos materiais no setor de têxtil e moda, que carece de bibliografia específica que reúna uma análise técnica e estética abrangendo todas as fases produtivas de materiais, processos, criação e design. 


\section{REFERÊNCIA BIBLIOGRÁFICAS}

ABIT. A Real Conjuntura da Indústria Têxtil e de Confecção Brasileira. Disponível em <www.iemi.com.br> Acesso em 10 fev. 2012.

ABIT. ABIT participa de projeto de Formação e Inclusão Social. Disponível em <http://www.abtt.org.br/boletim/boletim12/abit3.htm> Acesso em 09 jan. 2012.

ABIT. I Congresso Brasileiro de Lavanderias, 2010. Disponível em <http://www.anel.com.br/dyn_images/Haroldo\%20Silva\%20-\%20ABIT\%20\%20Uma\%20vis\%C3\%A30\%20geral\%20da\%20ind\%C3\%BAstria\%20e\%20 do\%20mercado\%20t\%C3\%AAxtil\%20e\%20de\%20confec\%C3\%A7\%C3\%A 3o.pdf> Acesso em 07 Jan. 2012.

$A B I T$. Pesquisa de usos, hábitos e costumes do consumidor de vestuário - Edição 2011. Ministério do desenvolvimento, indústria e comércio exterior. 2011.

ABIT. Guia Têxtil 2011. Disponível em $<$ http://www.guiatextil.com/site/noticias/industria/abit_esclarece_principais_d uvidas_das_normas_de_vestibilidade> Acesso em: 08 Set. 2012.

ABRELPE. A sociedade não pode mais sofrer com remendos ambientais. Disponível em <http://www.abrelpe.org.br/noticias_clipping_detalhe.cfm?NotClipping ID=91 9> Acesso em: 02 Set. 2012.

ADEME - AGENCE DE L'ENVIRONNEMENT ET DE LA MAîTRISE DE L'ENERGIE. An Environmental Product Declaration of Jeans. What to do to reduce the environmental impacts of one's pair of jeans. France, 2006.

ALFIERI, Paulo. Tecnologia das Fibras Têxteis III (apostila). Faculdade de Engenharia Industrial - FEl. Departamento de Engenharia Têxtil. São Bernardo - SP, 2012. 
ALVES, Salete Martins; OLIVERIA, João Fernando Gomes de. Adequação ambiental dos processos usinagem utilizando Produção mais Limpa como estratégia de gestão ambiental. São Paulo: Departamento de Eng. Mecânica - EESC-USP, 2007.

ALMEIDA, Cecília M. V. B.; GIANNETTI, Biagio F. Ecologia Industrial Conceitos, ferramentas e aplicações. São Paulo: Ed. Edgard Blucher, 2009.

ALMEIDA, Michelle; REZENDE, Mirabel. Resistência ao Cisalhamento Interlaminar de Compósitos com Resina Epóxi com Diferentes Arranjos das Fibras na Presença de Vazios. Polímeros, vol.1, no.4, ISSN 0104-1428, São Carlos, 2001.

ALVA, Gerson Moacyr Sisniegas. Comportamento dos Materiais e das Estruturas.

Disponível

em <http://www.ufsm.br/decc/ECC1006/Downloads/Aulas_5_6_2sem_2010.pdf $>$ Acesso em 27 nov. 2012.

ALYA ECO. Alya Fibra. Disponível em <http://www.alya.com.br/site/alya/pt/fibras-alya/alya-eco/alya-eco.aspx> Acesso em: 08 de jan. 2012.

ALWOOD, Julian et al. Well dressed? The present and future sustainability of clothing and textiles in the United Kingdom. London: University of Cambridge Institute for Manufacturing, 2006.

APEX-BRASIL. Exportação da Moda Brasileira. Disponível em: http://www.apexbrasil.com.br/portal/. Acesso em: 12 dez. 2010.

ARAÚJO, Eli Santos et al. Ecologia Industrial: um Pouco de História. Disponível em <http://www.hottopos.com/regeq12/art2.htm> Acesso em: 12 fev. 2012.

ARDUIN, Rachel Horta. PACCA, Sérgio Almeida. O Estado da Arte da Aplicação da Avaliação do Ciclo de Vida no Setor Têxtil e do Vestuário. $2^{\circ}$ Congresso Brasileiro em Gestão de Ciclo de Vida em Produtos e Serviços. Florianópolis - SC, 2010. 
ART. Woman in the Garden c. 1867. Disponível em <http://www.art.com/products/p13209323-sa-i2320876/claude-monetwomen-in-the-garden-c1867.htm> Acesso em: 10 Abril 2012.

ARTSOL FIBER GLASS. Ficha Técnica das Resinas. Disponível em $<$ http://www.artsolfiberglass.com.br/show_book.php?story=4878> Acesso em 09 dez. 2012.

ASSOCIAÇÃO BRASILEIRA DO ALUMÍNIO - ABAL. Reciclagem no Brasil. Disponível em < http://www.abal.org.br/reciclagem/brasil.asp> Acesso em: 09 de abril 2012.

ASSOCIAÇÃO BRASILEIRA DO ALUMÍNIO - ABAL. São Paulo regulamenta Política Estadual de Resíduos Sólidos. Disponível em <http://www.abal.org.br/noticias/lista_noticia.asp?id=613> Acesso em 23 fev. 2012.

BARBIERI, José C. Desenvolvimento e meio ambiente. As estratégias de mudanças da agenda 21. 5. ed. Petrópolis: Vozes, 2002.

BASRA, Amarjit S.; MALIK, C. P. Development of the Cotton Fibrer. Departament of Botany - Punjab Agricultural University. International Review of Cytology, vol. 89. ISBN 0-12-364489-5, Ludhiana - India, 1989.

BERSEN, Jens. Design: defina primeiro o problema. Florianópolis: Ed. SENAI/LBDI, 1995.

BEZERRA, Marcelo. Interações no Ensino e na Prática do Design e da Arquitetura. Dissertação (Mestrado em Artes) - Pontifícia Universidade Católica do Rio de Janeiro, Departamento de Artes e Design, Rio de Janeiro - RJ, 2004.

BIOMATER.

Bioplásticos.

Disponível

em <http://www.biomater.com.br/pt/bioplastico/> Acesso em 17 Nov. 2012.

BONIVITTA. Resina Bonivitta. Disponível em <http://www.bonivitta.com.br/> Acesso em: 17 Set. 2011. 
BUARQUE, Sergio C. Construindo o desenvolvimento sustentável local. Metodologia de planejamento. Ed. Garamond. Rio de Janeiro. 2008.

BRAGA, João. História da Moda: uma narrativa. São Paulo: Ed. AnhembiMorumbi, 2004.

BRASIL, lei ํㅜ 12.305, de 2 de agosto de 2010. Institui a Política Nacional de Resíduos Sólidos; altera a Lei no 9.605, de 12 de fevereiro de 1998; e dá outras providências. Disponível em <ttp://www.planalto.gov.br/ccivil_03/_ato2007-2010/2010/lei/12305.htm> Acesso em: 05 de Julho de $201 \overline{1}$.

BRASÍLIA CAPITAL BLOG. Eden: Marca utiliza algodão 100\% orgânico. Disponível em <http://www.bsbcapital.com.br/2011/04/eden-marca-utilizaalgodao-100-organico.html> Acesso em: 10 Abril 2012.

BROEGA, Cristina; CARVALHO, Cristina; MORAES, Carla. Metodologia de Eco-Design no Ciclo da Moda: Reutilização e reciclagem do desperdício de vestuário. In: Anais do VI Congresso Nacional de Pesquisa em Design, 2011.

BROWN, H.C. et al. Baude, E.A. and Nachod, F.C., Determination of Organic Structures by Physical Methods, Academic Press, New York, 1955.

CALDAS, Dario. Universo da Moda. São Paulo: Ed. Anhembi-Morumbi, 1999.

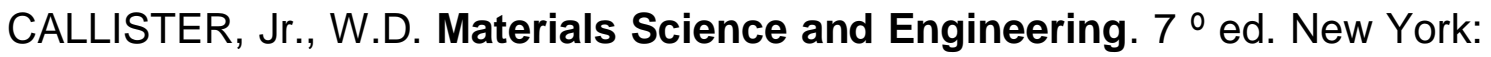
John Wiley \& Sons, Inc, 2007.

CARVALHO, Ricardo Fernandes. Compósitos de fibras de sisal para uso em reforço de estruturas de madeira. Tese (Doutorado em Ciência e Engenharia de Materiais). Universidade de São Paulo - Escola de Engenharia de São Carlos - Instituto de Física e Instituto de Química de São Carlos. São Carlos - SP, 2005. 
CELSO LIMA ESTAMPARIA. Linho. Disponível em <http://celsolima.zip.net/arch2007-08-26_2007-09-01.html> Acesso em 10 Abril 2012.

CENESTAP - Centro de Estudos Têxteis Aplicados. Mercados Mundiais para Têxteis Técnicos: Previsões para 2010. Braga (Portugal): 2004.

CNTL - CENTRO NACIONAL DE TECNOLOGIAS LIMPAS. Centro Nacional de Tecnologias Limpas. Disponível em: <http://www.senairs.org.br/cntl/>. Acessado em 23 fev. 2012.

CETESB (São Paulo). Manual para implementação de um programa de prevenção à poluição. 4.ed. São Paulo, 2002. (Relatórios ambientais). Disponível em: <http://www.cetesb.sp.gov.br/Tecnologia/producao_limpa/documentos/man ual_implem.pdf>. Acesso em: 23 fev. 2012.

CIETTA, Enrico. A Revolução do fast-fashion: estratégias e modelos organizativos para competir nas indústrias híbridas. São Paulo: Ed. Estação das Letras e Cores, 2010.

COLLIER, Ann M. A Handbook of Textiles. Pergamon Press: Oxford, 1970.

COSSOLINO, L.C.; PEREIRA, A. H. A. Módulos elásticos: visão e modo de caracterização. Informativo Técnico-Científico ITC-ME/ATCP Física. Disponível em <www.atcp.com.br> Acesso em 08 Dez. 2012.

COSTA, Deibson Silva. FUJIYAMA, Roberto Tetsuo. Fibras de Bambu como Agregação de Valor: do Artesanato a Materiais de Engenharia. In: I Congresso Internacional de Criatividade e Inovação. Anais - Trabalhos Completos, UFAM, Amazonas - AM, 2011

COOPA-ROCA. Quem somos. Disponível em http://www.cooparoca.rj.gov.br/quem_somos.asp> Acesso em: 09 jan. 2012.

CORRÊA, L. A. Comércio e meio ambiente: atuação diplomática brasileira em relação ao selo verde. Brasília: Instituto Rio Branco; Fundação Alexandre de Gusmão, 1998. 
CULTURA MIX. Broche de flor de fuxico. Disponível em $<$ http://artesanato.culturamix.com/tecido/fuxico/broche-de-flor-de-fuxicopasso-a-passo> Acesso em 10 Abril 2012.

CHEHEBE, José Ribamar. Análise do Ciclo de Vida dos produtos ferramenta gerencial da ISO 14.000. Ed. Qualitymark. Rio de Janeiro. 1998.

CLOSET ON LINE. Pesquisa inédita traça perfil do consumidor brasileiro de vestuário. Disponível em <http://www.closetonline.com.br/noticia/jornalismo+de+moda/\%20Todas\%20-

/6286/Pesquisa+in\%C3\%A9dita+tra\%C3\%A7a+perfil+do+consumidor+brasil eiro+de+vestu\%C3\%A1rio> Acesso em 01 abril 2012.

CNI - CONFEDERAÇÃO NACIONAL DAS INDÚSTRIAS e ABIT ASSOCIAÇÃO BRASILEIRA DA IND. TÊXTIL E DE CONFECÇÃO. Têxtil e confecção: Inovar, desenvolver e sustentar. CNI. Brasília, 2012.

DAHLLÖF, L. Methodological Issues in the LCA Procedure for the Textile Sector - A case study concerning fabric for a sofa. Chalmers University of Technology, 2004.

DEMETRESCO, Sylvia. Vitrinas em diálogos urbanos. São Paulo. Ed: Anhembi-Morumbi, 2005.

DIÁRIO DE SP. Comerciantes, compradores e moradores querem solução para lixo acumulado nas ruas. Disponível em <http://textileindustry.ning.com/forum/topics/bom-retiro-quer-limpeza> Acesso em 01 Abril 2012.

DINÂMICA LAVANDERIA. Tecido sarja. Disponível em $<$ http://www.dinamicalavanderia.com.br/curiosidades2.php> Acesso em 09 dez. 2012.

DONA DE CASA. Patchwork - um luxo. Disponível em <http://donadonadecasa.blogspot.com.br/2009/06/patchwork-um-luxo.html> Acesso em: 10 Abril 2012. 
ECCOTEXTIL. Brasil é o 4 maior produtor têxtil mundial. Disponível em <http://www.gestaotextil.com> Acesso em 07 jan. 2012.

ECOFASHIONMAG. Conselho americano de reciclagem têxtil lança site e promove educação ambiental. Disponível em <http://www.ecofashionmag.com/portal/tag/reciclagem-da-industria-textil/> Acesso em: 20 fev. 2012.

ECOTECE. Sustentabilidade. Disponível em <http://www.ecotece.org.br/definicao.php?i=71> Acesso em: 19 fev. 2012.

EMPLASA. Centro Urbano - Bom Retiro. Disponível em <http://www.emplasa.sp.gov.br/portalemplasa/uit/CENTRO/BOMRETIRO.pd f> Acesso em: 25 Mar. 2012.

EMPRAPA - Empresa Brasileira de Pesquisa Agropecuária. Algodão (Bt). Disponível em <http://www.cnpma.embrapa.br/projetos/index.php3?sec=bioss::.23>, acesso em: 14 nov. 2011.

ERKMAN S.; FRANCIS, C.; RAMASWAMY R. Ecologia Industrial: uma agenda para a evolução do sistema industrial. Cadernos de Preposições para o Século XXI, 12. São Paulo: Instituto Pólis, 2005.

FABRICLINK. Fiação a anel. Disponível em $<$ http://www.fabriclink.com/university/yarnfacts.cfm> Acesso em $08 \mathrm{dez}$. 2012.

FELIPE, Renata Carla. Compósitos (apostila). Disponível em <http://www.ebah.com.br/content/ABAAAA6t0AH/apostila-compositos> Acesso em 24 nov. 2012.

FERRARI, Dalva Olivia Azambuja. Estudo Comparativo entre o Processo Criativo na Arquitetura e na Joalheria com ênfase nas Criações de Frank Gehry. Dissertação (Mestrado em Arquitetura e Urbanismo) Universidade de São Paulo, 2011. 
FFW. Croquis de Yves Saint Laurent. Disponível em <http://ffw.com.br/noticias/category/moda/page/134/> Acesso em $01 \mathrm{dez}$. 2012.

FFW, Croquis de Cláudia Simões. Disponível em <http://ffw.com.br/ffwblog/tag/tng/> Acesso em 01 dez. 2012.

FIESP. Competitividade Sistêmica. Disponível em <www.fiesp.com.br> Acesso em 08 Abril. 2011.

FINKIELSZTEJN, Beatriz. Sistemas Modulares Têxteis como aproveitamento de fibras naturais Uma alternativa sustentável em Arquitetura \& Design. Dissertação (Mestrado em Artes) - Programa de Pós-Graduação em Artes da PUC-Rio. Rio de Janeiro - RJ, 2006.

FINKLER, Maira et al. Compósitos de HDPE com Resíduos de Fibras Têxteis. Parte I: Caracterização Mecânica. Polímeros: Ciência e Tecnologia, vol. 15, n 3, p. 171-175, 2005.

FLETCHER, K; GROSE, L. Moda e Sustentabilidade: Design para mudança. São Paulo: Ed. Senac, 2011.

FROSH, R. A.; GALLOPOULOS, N. E. Strategies for Manufacturing. Scientific American, Washington D.C. (EUA), v. 261, p. 144-152, 1989.

GAVRONSKI, luri et al. A learning and knowledge approach to sustainable operations. In: International Journal of Production Economics. Volume 140, Issue 1, November 2012, Pages 183-192.

GHAVAMI, K. Application of bamboo as a low-cost construction material. Proceedings of the Int'I Bamboo Workshop, nov. 1988.

GIANETTI, Biagio F. et al. Inventário de ciclo de vida da manufatura de seringas odontológicas. Associação Brasileira de Engenharia de Produção. São Paulo v.18, n.1, ISSN 0103-6513, 2008. 
GNT - GLOBO. Looks Moda do Futuro. Disponível em <http://gnt.globo.com/platb/tamanhounico/category/videos/> Acesso em: 10 Abril 2012.

GRAEDEL, T. E. Streamlined Life Cycle Assessment. By Bell Laboratories, Lucent Technologies. New Jersey: Ed. Pretice Hall, 1998.

HARRINGTON, D. R. Two-stage adoption of different types of pollution prevention (P2) activities. In: Resource and Energy Economics. Volume 34, Issue 3, September 2012, Pages 349-373.

HOLTZ, Marcos; SILVEIRA, Márcia Luciane L.; WISBECK, Elisabeth. Caracterização e utilização do resíduo de algodão da indústria têxtil para a produção de corpos frutíferos de Pleurotus ostreatus. In: VI CONGRESSO BRASILEIRO DO ALGODÃO, Paraíba, 2007. Disponível em: <http://www.cnpa.embrapa.br/produtos/algodao/publicacoes/cba6/trabalhos/ Biotecnologia/Trabalho\%20B05.pdf> Acesso em: 18 fev. 2012.

HOTEL-TOWEL. Fio produzido por fiação a anel e por fiação a rotor. Disponível em < http://www.hotel-towel.com/study.html> Acesso em 08 dez. 2012.

IDEC. Cadeia de valor do algodão, têxtil e vestuário: um estudo prospectivo. 2005.2 Disponível em <http://www.idec.org.br/arquivos/relatorio_cadeia_algodao.pdf> Acesso em: 13 nov. 2011.

IPT-SEBRAE. Cooperativa de Catadores de Materiais Recicláveis - Guia para Implantação. São Paulo: Publicação IPT, 2003.

IRMÃOS CAMPANA. Série de móveis Sushi. Disponível em $<$ http://arteparaocoracao.blogspot.com.br/2009/07/made-in-brasildesigners-irmaos-campana.html> Acesso em 03 dez. 2012.

ITMF - International Textile Manufactures Federation. World Textile Summit 2011. Disponível em < http://www.worldtextilesummit.com/> Acesso em 04 nov. 2012. 
JENSEN, Allan et al. Life Cycle Assessment (LCA) - A guide to approaches, experiences and information sources. 1997. Disponível em <http://themes.eea.eu.in/index.php> Acesso em 19 fev. 2012.

KASWELL, E. R. Wellington Sears Handbook of Industrial Textiles. Massachusetts Institute of Technology (MIT) e Wellington Sears Company, Cambridge, Estados Unidos, 1963.

LAVER, James. A Concise History of Costume. Londres, Ed. Thames \& Hudson, 1995

LDSM - UFRGS. Laboratório de design e seleção de materiais. Disponível em <http://www.ndsm.ufrgs.br/> Acesso em 06 dez. 2012.

LESKO, Jim. Design Industrial - Guia de Materiais e Fabricação. 2a edição. São Paulo: Ed. Edgard Blucher, 2012.

LEVI STRAUSS \& CO. A Product Lifecycle Approach to Sustainability. San Francisco, CA, 2009.

LIMA, Angela Maria Ferreira. Avaliação do Ciclo de Vida no Brasil - Inserção de Perspectivas. Dissertação (Mestrado Profissional em Gerenciamento e Tecnologias Ambientais no Processo Produtivo) - Escola Politécnica, Universidade Federal da Bahia. Salvador - BA, 2007.

LIPOVETSKY, Gilles. O Império do Efêmero. São Paulo: Companhia das Letras, 1989.

LIPOVETSKY, G. O luxo eterno. São Paulo. Companhia das letras, 2004.

LLAGOSTERA, Enric Granzotto; HILDEBRAND, Hermes Renato. Estudo de Metodologias para Roteirização em Hipermídias. Disponível em $<$ http://www.trilhas.iar.unicamp.br/texto/lC_Enric.pdf> Acesso em $01 \mathrm{dez}$. 2012. 
LÖBACH, Bernd. Design industrial: bases para a configuração dos produtos industriais. Tradução: Freddy Van Camp. 1. ed. São Paulo: Editora Edgard Blücher Ltda. 2001, 206p.

LOGA - Logística Ambiental de São Paulo. Entrevista realizada com o Sr. Francisco Vianna no dia 18/08/2011.

LOGA - Logística Ambiental de São Paulo. Disponível em <www.loga.com.br> Acesso em 26 fev. 2012.

LOJÃO DO BRÁS. Calça Jeans Masculina. Disponível em $<$ http://www.lojaodobras.com.br/produtop.php?id=18> Acesso em: 10 Abril 2012.

LUMI, Cassiano Tiago. Estudo de Caso para Redução da Geração de Sucata de Alumínio de uma Empresa do Setor Metal-Mecânico Dissertação (Mestrado Profissional em Engenharia: Energia, Ambiente e Materiais) - Universidade Luterana do Brasil. Canoas - RS, 2009.

MACEDO, Angela Maria Kuasne da Silva. Fibras Têxteis. Disponível em $<$ https://wiki.ifsc.edu.br/mediawiki/images/9/9c/Apostila_de_fibras.pdf > Acesso

em

05

dez.

2012.

MALUF, E.; KOLBE, W. Manual - Dados técnicos para a indústria têxtil. $2^{\text {a }}$ ed. São Paulo, IPT - Instituto de Pesquisas Tecnológicas e ABIT Associação Brasileira da Indústria Têxtil e da Confecção, 2003.

MANZINI, Ezio; VEZZOLI, Carlo. O Desenvolvimento de Produtos Sustentáveis. São Paulo: Ed. Edusp, 2009.

MARQUES, Antonio Torres. Materiais Compósitos: um desafio permanente. Instituto de Engenharia Mecânica e Gestão Industrial. Disponível em <http://www.spmateriais.pt/INEGI.htm> Acesso em: 03 Set. 2012.

MARSH, Graham. Denim: l'épopée illustrée d'un tissu de legend. Éd. du Collectionneur, 2003. 
MARTINS, S. B.; SAMPAIO, C. P. Ecodesign e design sustentável: proposta de método para um workshop. In: Congresso Brasileiro de Pesquisa e Desenvolvimento em Design, P\&D DESIGN, 7, Curitiba, 2006.

MARUM, Luana Lasincki e GOMES, José Antonio. O Bom Retiro: a formação de uma centralidade. USP/FFLCH. São Paulo, 2005.

MATTOS, Paulo Todescan Lessa. O Novo Estado Regular no Brasil: Eficiência e Legitimidade. São Paulo: Ed. Singular, 2006.

MESDAN-LAB. Operating instructions \& maintenance: Video Analyser 2000, Microlab Advance, Macrolab Advanced. Ed. Prima: Itália, 2005.

MILAN, G.S.; VITORAZZI, C.; REIS, Z.C. Um estudo sobre a redução de resíduos têxteis e de impactos ambientais em uma indústria de confecções do vestuário. VI Congresso Nacional em Excelência de Gestão. ISSN 1984-9354. Rio de Janeiro, 2010. Disponível em <http://www.excelenciaemgestao.org/Portals/2/documents/cneg6/anais/T10 _0237_0980.pdf> Acesso em: 28 jan. 2011.

MIU MIU. Catálogo Miu Miu. Disponível em <www.miumiu.com> Acesso em: 10 abril 2012.

MODA ECOLÓGICA. Moda ecológica estimula consumo consciente. Disponível em <http://modaecologica.blogspot.com/> Acesso em: 20 fev. 2012.

MOLDFLEX. Ficha técnica da resina poliuretano Poly-Optic 1411. 2012.

NETCOMPOSITES. Resina epóxi. Disponível em $<$ http://www.netcomposites.com/guide/epoxy-resins/10> Acesso em $09 \mathrm{dez}$. 2012.

OLX. Manta de Fuxicos. Disponível em <http://marilia.olx.com.br/manta-defuxico-iid-5574013> Acesso em: 10 Abril 2012. 
ORÉFICE, Rodrigo. Compósitos. Disponível em <http://www.demet.ufmg.br/docentes/rodrigo/compositos.htm> Acesso em: 05 de Julho de 2011.

PAPANEK, Victor. Design for a Real World: Human Ecology and Social Change. Chicago: Academy Chicago, 1985.

PENCE FUNDAMENTAL. Moda sustentável: eco fashion. Disponível em $<$ http://pencefundamental.wordpress.com/tag/acessorios-reciclados/> Acesso em: 10 Abril 2012.

PEREIRA, Gislaine de Souza. Materiais e Processos Têxteis (apostila). Instituto Federal de Educação, Ciência e Tecnologia. Departamento Têxtil. Campus Araranguá - SC, 2009.

PICCOLI, H.H. Determinação do comportamento tintorial de corantes naturais em substrato de algodão. Dissertação (Mestrado em Engenharia Química) - Universidade Federal de Santa Catarina, Centro Tecnológico, Florianópolis, 2008.

POLHEMUS, Ted. Street Style. Londres: Ed. Thames and Hudson, 1994.

POLHEMUS, Ted. Surfing Style. Londres: Thames and Hudson, 1997.

POLIRESINAS. Resinas poliéster. Disponível em <http://www.poliresinas.com.br/blog/noticias-e-novidades/ortoftalicatereftalica-ou-isoftalica/> Acesso em 09 dez. 2012.

PORTAL JOINVILLE. Lonas são transformadas em aventais. Disponível em $<$ http://www.portaljoinville.com.br/v3/?call=noticias.view\&id=19718> Acesso em: 02 Set. 2012.

PUKÁNSZKY, B. Influence of interface interaction on the ultimate tensile properties of polymer composites. In: Composites, Volume 21, Issue 3, May 1990, Pages 255-262.

PREUSSLER, Maria Fernanda et. al. Rotulagem Ambiental - Um Estudo Sobre NR'S. In: 1st International Workshop Advances in Cleaner Production e IV Semana Paulista de P+L/Conferência Paulista de P+L, São Paulo-SP, 2007. 
QUEIROZ, Leila Lemgruber. O lixo urbano e a questão do Ecodesign: a relevância do plástico biodegradável. Dissertação (mestrado em Design) - Departamento de artes e Design, PUC-Rio, Rio de Janeiro -RJ, 2003.

QUEIROZ, R.S. Aplicabilidade de Fibras Vegetais Alternativas Brasileiras na Produção de Materiais Têxteis. 2007. Monografia (Iniciação Científica CNPq - Escola de Artes, Ciências e Humanidades) - Universidade de São Paulo, São Paulo - SP, 2007.

RABELO, M. Aditivação de Polímeros. São Paulo: Ed. Artliber, 2000.

RAFAELLA HARDMAN. Patchwork. Disponível em $<$ http://rafaellahardman.wordpress.com/tag/patchwork/> Acesso em 10 Abril 2012.

RANDALL, D. The Polyurethanes Book. New York: Ed. Wiley, 2002.

RECICLÁVEIS. Garrafas plásticas viram jeans. Disponível em <http://www.reciclaveis.com.br/noticias/00408/0040812jeans.htm> Acesso em 08 de jan. 2012.

RECH, Sandra. Moda Palavra - Fundamentos da gestão do design de moda. Vol. 3. Florianópolis: Centro de Artes (CEART)/UDESC, 2004.

RECICLANTO. Poltrona Butterfly. Disponível em <http://reciclanto.blogspot.com.br/> Acesso em: 28 Ago. 2012

RECITEX RECICLADOS TÊXTEIS LTDA. Processos. Rio Grande do Sul. Disponível em: <http://recitex.com.br/processos/cont_processos.htm>. Acesso em: $18 \mathrm{fev}$. 2012.

RECYCLED PRODUCTS. Recycled Products. Disponível em <http://www.recycledproducts.org.uk/view/>. Acesso em: 10 fev. 2012.

REDLEASE. Ficha técnica da resina poliéster ortoftálico Arazyn 1.0. 2012. 
RESMAT. Aula de resistência dos materiais. Disponível em http://www.mspc.eng.br/matr/resmat0140.shtml. Acesso em 23 de Mar. 2012.

REVISTA FATOR. Setor de nãotecidos e tecidos técnicos é o maior reciclador de PET do país. Disponível em $<$ http://www.revistafator.com.br/ver_noticia.php?not=178368> Acesso em: 09 jan. 2012.

REVISTA GLOBO RURAL. Área plantada com algodão no Cerrado da Bahia cresce 48\% em 2010/2011. Disponível em <http://revistagloborural.globo.com/Revista/Common/0,,EMI206061$18078,00-$

AREA+PLANTADA+COM+ALGODAO+NO+CERRADO+DA+BAHIA+CRES CE+EM.html> Acesso em 10 Abril 2012.

RICKEN, L. C.; POZZA, P. P.; TEIXEIRA, J. A. Eco-design: escolha de materiais visando sustentabilidade e processos de fabricação. In: Anais do $8^{\circ}$ Congresso Brasileiro de Pesquisa e Desenvolvimento em Design. ISBN: 978-85-60186-03-7. Associação de Ensino e Pesquisa de Nível Superior de Design do Brasil. São Paulo, 2008.

R. SOBRAL. Coleção Bijuterias. Disponível em <www.rsobral.com.br $>$ Acesso em 03 dez. 2012.

SALLES, Cecília Almeida. Crítica Genética: fundamentos dos estudos genéticos sobre o processo de criação artística. $3^{a}$ ed. revista. São Paulo: EDUC, 2008.

SANTANA TEXTILES. Linha Absynto. Disponível em <http://www.santana.ind.br/pt/santana-loco/> Acesso em 05 dez. 2012.

SANTANENSE. Glossário - mercerização. Disponível em $<$ http://www.santanense.com.br/central-detreinamento/glossario.aspx?idSetor=1\&letra=M> Acesso em 05 dez. 2012.

SAVILLE, B.P. Physical testing of textiles. The Textile Institute Woodhead Publishing Limited, Cambridge, 2007. 
SBRT - Serviço Brasileiro de Respostas Técnicas. Tecido reciclado 1. Disponível em <http://dc270.4shared.com/doc/KMclc6Ny/preview.html> Acesso em: 18 fev. 2012.

SBRT - Serviço Brasileiro de Respostas Técnicas. Tecido reciclado 2. Disponível em < http://www.sbrt.ibict.br> Aceso em: 13 fev. 2012.

SCARLATO, F.; PONTIM, J. A. Do nicho ao lixo: sociedade, ambiente e educação. São Paulo: Ed. Atual, 1992.

SCHWARZ, Henrique. Três axiomas da economia ecológica. Disponível em <http://www.scielo.oces.mctes.pt/scielo.php?script=sci_arttext\&pid=S087374442009000300004\&lang=pt>. Acesso em 2 março 2011.

SCHWAB, Klaus. The Global Competitiveness Report 2010 - 2011. In: World Economic Forum. Genebra, Suíça, 2010.

SETAC - Society for Environmental Toxicology and Chemistry. Guidelines for LifeCycle Assessment: A Code of Practice. 1르 edição. Bruxelas. 1993.

SETOR RECICLAGEM. Gary Harvey. Disponível em $<h t t p: / / w w w . s e t o r r e c i c l a g e m . c o m . b r / m o d u l e s . p h p ? s e t \_a l b u m N a m e=a l b u m 1$ 8\&id=gary_harveys_creation1_9\&op=modload\&name=gallery\&file=index\&in clude=view_photo.php> Acesso em: 10 Abril 2012.

SHOES FOR FUN BY VH. Croquis da New Order. Disponível em < http://shoesforfunbyhv.wordpress.com/category/windows/page/2/> Acesso em 01 dez. 2012.

SILAEX. Epóxy. Disponível em < http://www.silaex.com.br/epoxi.htm > Acesso em 09 dez. 2012.

SIMMEL, Georg. Aufsätze 1887 bis 1890 . Über soziale Differenzierung. Die Probleme der Geschichtsphilosophie (1892). Gesamtausgabe Bd. 2. Frankfurt/M, Suhrkam, 1989. 
SP FASHION WEEK. São Paulo Fashion Week. Disponível em <http://sp.fashionweek.com.br/tag/semana-de-moda/> Acesso em 27 Mar. 2012.

STYLE. Louis Vuitton. Disponível em <http://www.style.com/fashionshows/review/F2010RTW-LVUITTON> Acesso: em 10 Abril 2012.

SILVA, Arlindo. Compósitos - Materiais II. Instituto Superior Técnico. Lisboa. Portugal. 2011.

SLATER, DON. Cultura do consumo e modernidade. Editora Abril S.A. São Paulo, 2002.

STURCH, K.. Entrevista concedida ao portal Valor Econômico. Disponível em <http://www.valor.com.br/cultura/blue-chip/2493214/vida-pos-fastfashion> Acesso em: 19 fev. 2012.

TEIXEIRA, Maria Bernadete Santos. O que é design. Belo Horizonte: SEBRAE/MG, 2009.

TEXTILE INDUSTRY. Biotecnologia Aplicada à Indústria Têxtil. Disponível em <http://textileindustry.ning.com/profiles/blogs/biotecnologia-aplicada-a$6<>$ Acesso em 05 dez. 2012.

TEXTILE ON LINE. Textiles. Disponível em:<www.textileonline.com $>$ Acesso em: 13 Abril 2011.

THE FREE DICTIONARY. Resina poliuretano. Disponível em $<$ http://encyclopedia2.thefreedictionary.com/polyurethane+resin> Acesso em 09 dez. 2012.

TRIGUEIRO, André. Mundo Sustentável: abrindo espaço na mídia para um planeta em transformação. São Paulo: Editora Globo, 2005. 
UTL - Universidade Técnica de Lisboa. Propriedades Mecânicas de Metais, Cerâmicos e $\quad$ Polímeros. Disponível em <http://disciplinas.ist.utl.pt/qgeral/mecanica/MetCerPol.pdf> Acesso em 24 nov. 2012.

VALOR ECONÔMICO. A economia pós-industrial. Disponível em <http://www.valor.com.br/opiniao/2534946/economia-pos-industrial> Acesso em 18 fev. 2012.

WAIZBORT, Leopoldo. Gerog Simmel sobre a Moda - uma aula. Disponível em<http://xa.yimg.com/kg/groups/17786142/1847774889/name/03_IARA_Si mmel_versao_final.pdf> Acesso em 19 fev. 2012.

WASTE ON LINE. Textile recycling information sheet. Disponível em <www.wasteonline.com> Acesso em: 28 Fev. 2011.

WASTE SAVERS. Waste Savers. Disponível em <http://www.wastesavers.co.uk> Acesso em 10 fev. 2012.

WECHSLER, S. M. Criatividade: descobrindo e encorajando. 3a. edição. IDB/LAMP-PUC-Campinas, 2008.

ZARA. Catálogo Zara. Disponível em <www.zara.com.br> Acesso em: 10 Abril 2012. 


\section{NORMAS TÉCNICAS}

ABNT- Associação Brasileira de Normas Técnicas.NBBR 13370. Coletânea de

Normas Técnicas de Nãotecidos. Rio de Janeiro: ABNT, 2002.

Norma da "American Association of Textile Chemists and Colorists" (para análise de fibras). AATCC 20-1995: Fiber analysis: qualitative. v. 71, p. 50-59. Research Triangle Park, 1996. $10 \mathrm{p}$

Norma da Associação Brasileira de Normas Técnicas (para análise microscópica). ABNT NBR 13 538-1995: Material têxtil - Análise qualitativa. 20p.

Norma da Associação Brasileira de Normas Técnicas. ABNT ISO 139:2005: Têxteis Atmosferas normais de condicionamento de ensaios. $6 p$.

Normas da "American Society of Testing Materials" (para alongamento e resistência no ensaio de tração). ASTM D 3 822-2001: Standard test method for tensile properties of single textile fibers. West Conshohocken, 2006. 10p.

Normas da "American Society of Testing Materials" (para alongamento e resistência no ensaio de tração). ASTM D 1445-05: Standard test methods for breaking strength and elongation of cotton fibers (Flat Bundle Method). West Conshohocken, 2006. $8 p$.

Norma "International Standards Organization" (para determinação do regain das fibras). SO/TR 6741-4 -1987: Textiles - Fibres and yarns - Determination of commercial mass of consignments- Part 4: Values used for the commercial allowances and the commercial moisture regains. $6 \mathrm{p}$. 


\section{APÊNDICES}

\subsection{Roteiro de Entrevista Feita Com a Concessionária Loga}

1- Qual o volume total de lixo produzido?

2 - Qual o volume do lixo têxtil produzido?

3 - Existe algum tipo de separação do lixo recebido? Se sim, como se dá?

4 - Existe algum programa de reciclagem do lixo recebido?

5 - Quem são/quais são os maiores produtores de lixo têxtil em São Paulo?

6 - A LOGA financia ou incentiva projetos sociais/ONG's?

7 - Qual é o perímetro urbano que a Loga atende? 


\subsection{Testes no Dinamômetro}

\subsubsection{Resina Epóxi Pura}

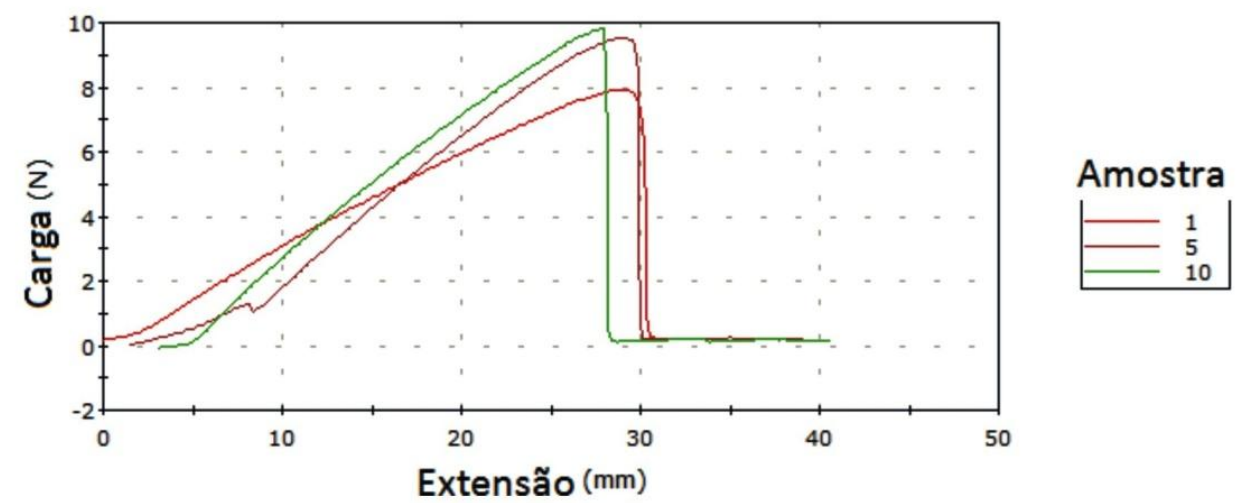

Figura 8.1. Resina epóxi pura: carga $(\mathrm{N})$ versus extensão $(\mathrm{mm})$

Tabela 8.1. Valores referentes à Carga Máxima $(\mathrm{N})$, Tenacidade (MPa), Extensão de Ruptura e Módulo ( $\mathrm{MPa}$ ) das amostras produzidas com resina epóxi. Os valores são dados com média, desvio padrão e coeficiente de variação.

\begin{tabular}{ccccc}
\hline & $\begin{array}{c}\text { Carga Máxima } \\
(\mathbf{N})\end{array}$ & $\begin{array}{c}\text { Tenacidade } \\
(\mathbf{M P a})\end{array}$ & $\begin{array}{c}\text { Extensão de Ruptura } \\
(\mathbf{m m})\end{array}$ & $\begin{array}{c}\text { Módulo } \\
(\mathbf{M P a})\end{array}$ \\
\hline 1 & 7,91951 & 0,07920 & 30,82350 & 0,33812 \\
5 & 9,53160 & 0,09532 & 37,43000 & 0,48129 \\
10 & 9,81218 & 0,09812 & 37,44312 & 0,53542 \\
\hline Média & $\mathbf{9 , 0 8 7 7 6}$ & $\mathbf{0 , 0 9 0 8 8}$ & $\mathbf{3 5 , 2 3 2 2 0}$ & $\mathbf{0 , 4 5 1 6 1}$ \\
$\begin{array}{c}\text { Desvio Padrão } \\
\text { Coeficiente de } \\
\text { Variação }\end{array}$ & $\mathbf{1 , 0 2}$ & $\mathbf{0 , 0 1}$ & $\mathbf{3 , 8 2}$ & $\mathbf{0 , 1 0}$ \\
\hline
\end{tabular}




\subsubsection{Resina Epóxi Reforçada com Fibras de Algodão}

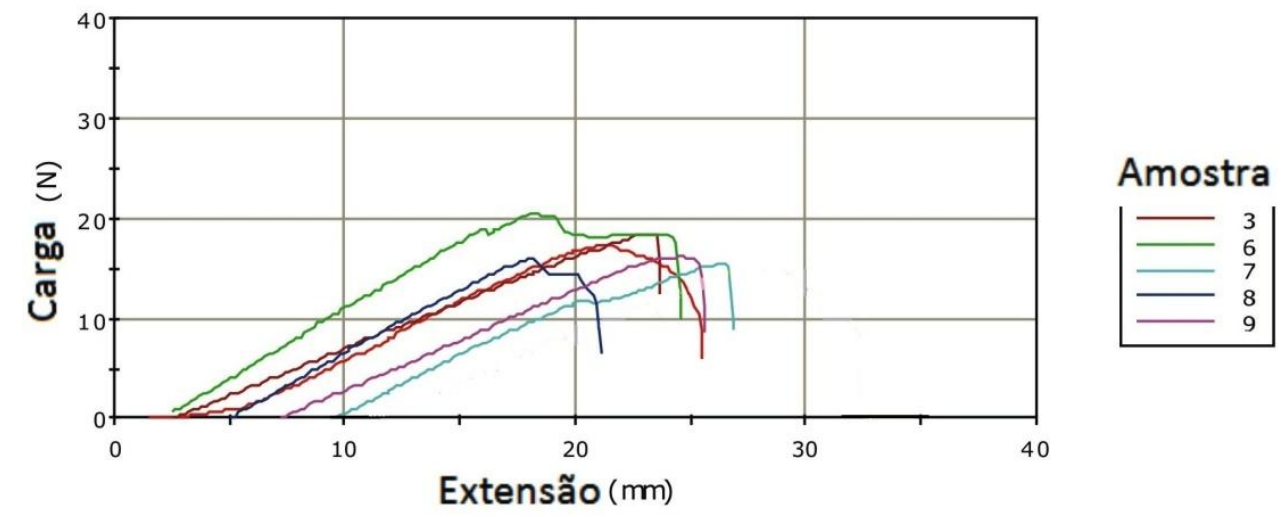

Figura 8.2. Resina epóxi reforçada com fibras de algodão: carga $(\mathrm{N})$ versus

$$
\text { extensão }(\mathrm{mm})
$$

Tabela 8.2. Valores referentes à Carga Máxima $(\mathrm{N})$, Tenacidade (MPa), Extensão de Ruptura e Módulo (MPa) das amostras produzidas com resina epóxi e reforçadas com fibras de algodão. Os valores são dados com média, desvio padrão e coeficiente de variação.

\begin{tabular}{ccccc}
\hline & $\begin{array}{c}\text { Carga } \\
\text { Máxima (N) }\end{array}$ & $\begin{array}{c}\text { Tensão da Carga } \\
\text { Máxima (MPa) }\end{array}$ & $\begin{array}{c}\text { Extensão de } \\
\text { Ruptura (mm) }\end{array}$ & $\begin{array}{c}\text { Módulo } \\
(\mathbf{M P a})\end{array}$ \\
\hline 3 & 17,35367 & 0,17354 & 25,49987 & 1,21979 \\
6 & 18,60067 & 0,18601 & 22,33337 & 0,95645 \\
7 & 15,58728 & 0,15587 & 22,83350 & 1,18474 \\
8 & 16,13886 & 0,16139 & 15,99987 & 1,33709 \\
9 & 16,26188 & 0,16262 & 19,16675 & 1,03172 \\
\hline Média & $\mathbf{1 6 , 7 8 8 4 7}$ & $\mathbf{0 , 1 6 7 8 8}$ & $\mathbf{2 1 , 1 6 6 6 7}$ & $\mathbf{1 , 1 4 5 9 6}$ \\
$\begin{array}{c}\text { Desvio Padrão } \\
\begin{array}{c}\text { Coeficiente de } \\
\text { Variação }\end{array}\end{array}$ & $\mathbf{1 , 2 0}$ & $\mathbf{0 , 0 1}$ & $\mathbf{3 , 6 6}$ & $\mathbf{0 , 1 5}$ \\
\hline & $\mathbf{7 , 1 4}$ & $\mathbf{7 , 1 4}$ & $\mathbf{1 7 , 3 0}$ & $\mathbf{1 3 , 2 7}$ \\
\hline
\end{tabular}




\subsubsection{Resina de Poliéster Pura}

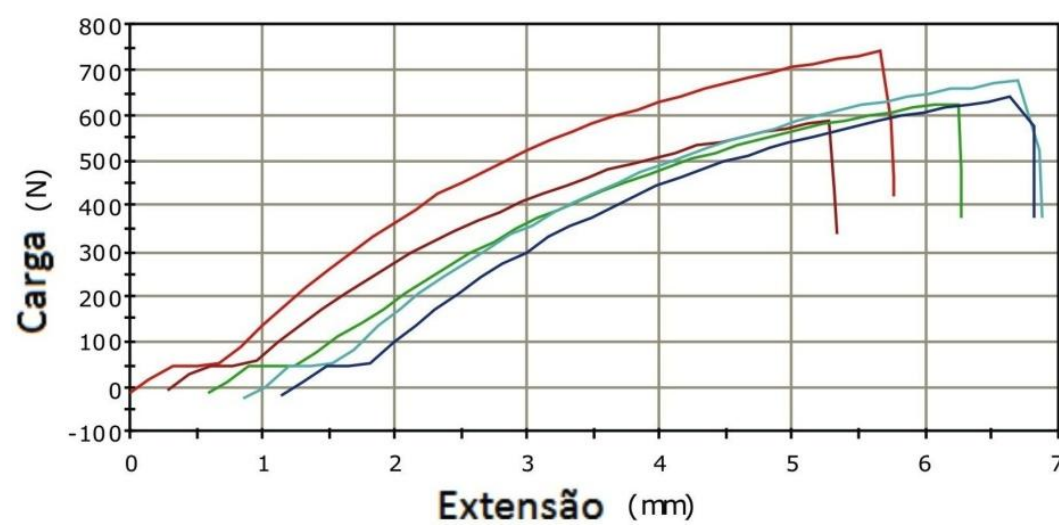

\section{Amostra}

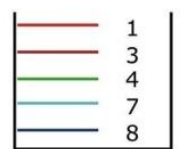

Figura 8.3. Resina de poliéster pura: carga $(\mathrm{N})$ versus extensão $(\mathrm{mm})$

Tabela 8.3. Valores referentes à Carga Máxima $(N)$, Tenacidade (MPa), Extensão de Ruptura e Módulo (MPa) das amostras produzidas com resina de poliéster pura com média. Os valores são dados com desvio padrão e coeficiente de variação.

\begin{tabular}{ccccc}
\hline & $\begin{array}{c}\text { Carga Máxima } \\
(\mathbf{N})\end{array}$ & $\begin{array}{c}\text { Tenacidade } \\
(\mathrm{MPa})\end{array}$ & $\begin{array}{c}\text { Extensão de } \\
\text { Ruptura }(\mathbf{m m})\end{array}$ & $\begin{array}{c}\text { Módulo } \\
(\mathrm{MPa})\end{array}$ \\
\hline 1 & 742,85893 & 7,42859 & 5,66669 & 227,64614 \\
3 & 589,62177 & 5,89622 & 5,00012 & 184,08476 \\
4 & 625,27829 & 6,25278 & 5,66662 & 178,70023 \\
7 & 674,91382 & 6,74914 & 5,99356 & 187,61903 \\
8 & 637,09635 & 6,37096 & 5,66675 & 191,91437 \\
\hline Média & $\mathbf{6 5 3 , 9 5 3 8 3}$ & $\mathbf{6 , 5 3 9 5 4}$ & $\mathbf{5 , 5 9 8 7 5}$ & $\mathbf{1 9 3 , 9 9 2 9 1}$ \\
& $\mathbf{5 8 , 2 8}$ & $\mathbf{0 , 5 8}$ & $\mathbf{0 , 3 6}$ & $\mathbf{1 9 , 4 3}$ \\
$\begin{array}{c}\text { Desvio Padrão } \\
\begin{array}{c}\text { Coeficiente de } \\
\text { Variação }\end{array}\end{array}$ & $\mathbf{8 , 9 1}$ & $\mathbf{8 , 9 1}$ & $\mathbf{6 , 4 9}$ & $\mathbf{1 0 , 0 1}$ \\
\hline
\end{tabular}




\subsubsection{Resina de Poliéster Reforçada com Fibras de Algodão}

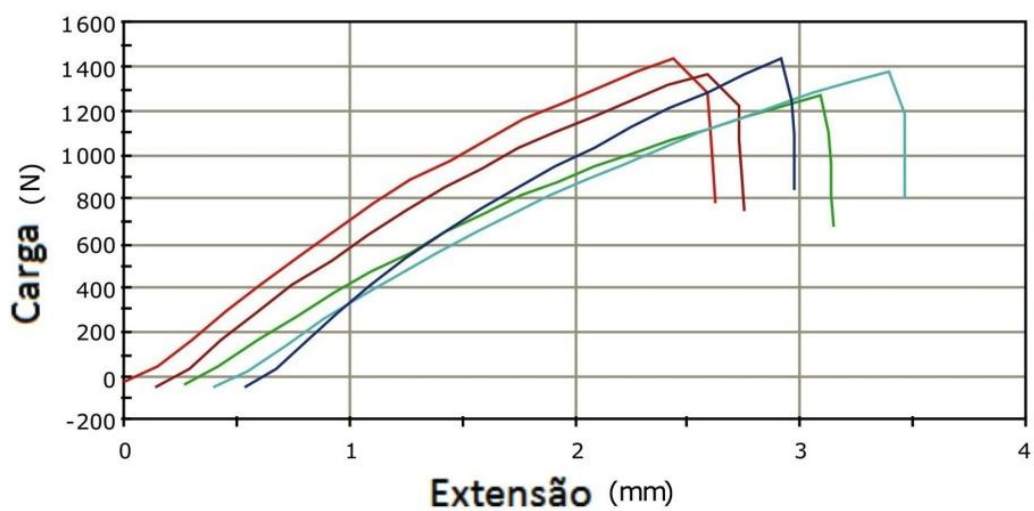

Amostra

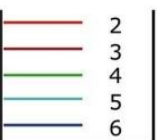

Figura 8.4. Resina de poliéster reforçada com fibras de algodão: carga (N) versus extensão $(\mathrm{mm})$

Tabela 8.4. Valores referentes à Carga Máxima (N), Tenacidade (MPa), Extensão de Ruptura e Módulo (MPa) das amostras produzidas com resina de poliéster e reforçada com fibras de algodão. Os valores são dados com desvio padrão e coeficiente de variação.

\begin{tabular}{|c|c|c|c|c|}
\hline & $\begin{array}{l}\text { Carga Máxima } \\
\text { (N) }\end{array}$ & $\begin{array}{l}\text { Tensão da Carga } \\
\text { Máxima (MPa) }\end{array}$ & $\begin{array}{l}\text { Extensão de } \\
\text { Ruptura (mm) }\end{array}$ & $\begin{array}{l}\text { Módulo } \\
\text { (MPa) }\end{array}$ \\
\hline 2 & $1.441,15798$ & 14,41158 & 2,59675 & 828,46601 \\
\hline 3 & $1.370,01704$ & 13,70017 & 2,45337 & 803,80627 \\
\hline 4 & $1.266,60271$ & 12,66603 & 2,83344 & 654,60337 \\
\hline 5 & $1.374,14634$ & 13,74146 & 3,00006 & 646,14566 \\
\hline 6 & $1.442,02551$ & 14,42025 & 2,39306 & 927,88106 \\
\hline Média & $1.378,78992$ & 13,78790 & 2,65534 & 772,18047 \\
\hline Desvio Padrão & 71,72 & 0,72 & 0,26 & 120,54 \\
\hline $\begin{array}{l}\text { Coeficiente de } \\
\text { Variação }\end{array}$ & 5,20 & 5,20 & 9,67 & 15,61 \\
\hline
\end{tabular}




\subsubsection{Resina de Poliuretano Pura}

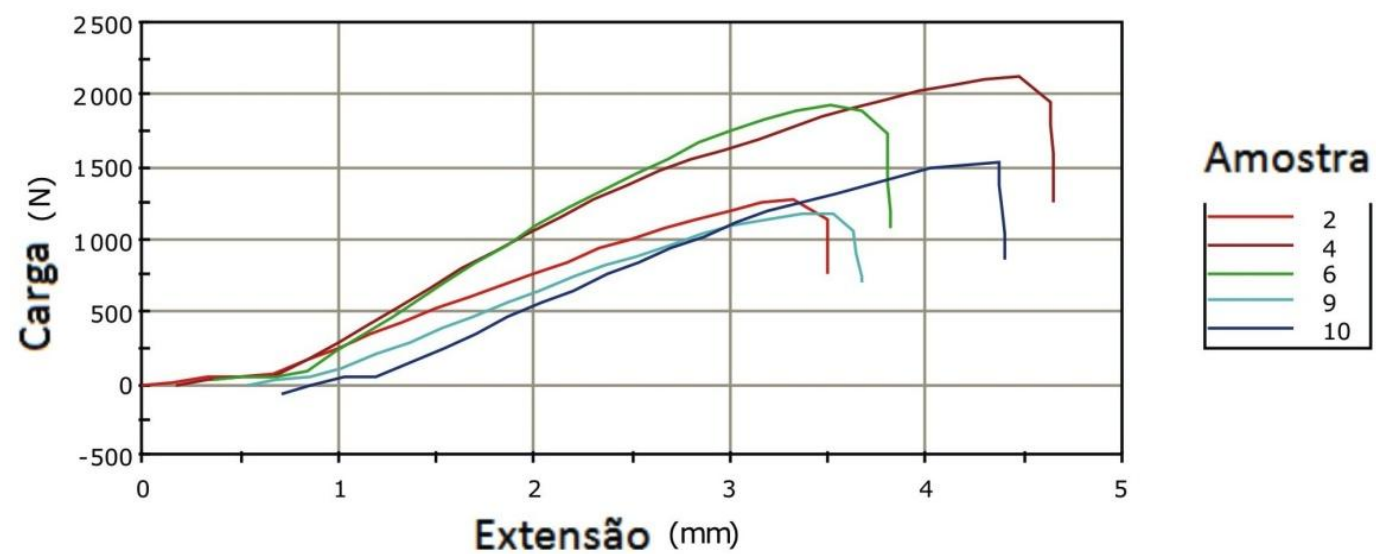

Figura 8.5. Resina de poliuretano: carga (N) versus extensão (mm)

Tabela 8.5. Valores referentes à Carga Máxima $(\mathrm{N})$, Tenacidade (MPa), Extensão de Ruptura e Módulo (MPa) das amostras produzidas com resina de poliuretano pura. Os valores são dados com desvio padrão e coeficiente de variação.

\begin{tabular}{ccccc}
\hline & $\begin{array}{c}\text { Craga Máxima } \\
(\mathbf{N})\end{array}$ & $\begin{array}{c}\text { Tenacidade } \\
(\mathbf{M P a})\end{array}$ & $\begin{array}{c}\text { Extensão de } \\
\text { Ruptura }(\mathbf{m m})\end{array}$ & $\begin{array}{c}\text { Módulo } \\
(\mathrm{MPa})\end{array}$ \\
\hline 2 & $1.277,74058$ & 12,77741 & 3,49019 & 546,55819 \\
4 & $2.120,26313$ & 21,20263 & 4,45700 & 767,23075 \\
6 & $1.929,51579$ & 19,29516 & 3,32625 & 901,81328 \\
9 & $1.176,74926$ & 11,76749 & 3,00012 & 562,68181 \\
10 & $1.532,39248$ & 15,32393 & 3,66687 & 618,75050 \\
\hline Média & $\mathbf{1 . 6 0 7 , 3 3 2 2 5}$ & $\mathbf{1 6 , 0 7 3 3 2}$ & $\mathbf{3 , 5 8 8 0 9}$ & $\mathbf{6 7 9 , 4 0 6 9 1}$ \\
& $\mathbf{4 0 8 , 2 1}$ & $\mathbf{4 , 0 8}$ & $\mathbf{0 , 5 4}$ & $\mathbf{1 5 1 , 7 6}$ \\
$\begin{array}{c}\text { Desvio Padrão } \\
\text { Coeficiente de } \\
\text { Variação }\end{array}$ & $\mathbf{2 5 , 4 0}$ & $\mathbf{2 5 , 4 0}$ & $\mathbf{1 5 , 1 7}$ & $\mathbf{2 2 , 3 4}$ \\
\hline
\end{tabular}




\subsubsection{Resina de Poliuretano Reforçada com Fibras de Algodão}

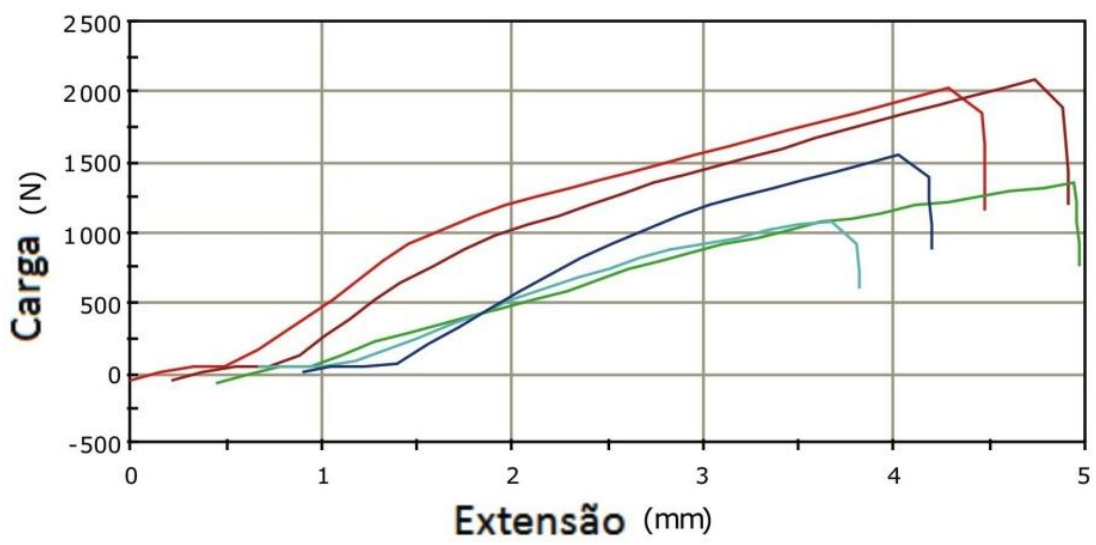

Amostra

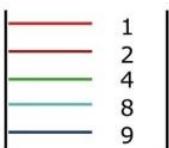

Figura 8.6. Resina de poliuretano reforçada com fibras de algodão: carga (N) versus extensão $(\mathrm{mm})$

Tabela 8.5. Valores referentes à Carga Máxima $(\mathrm{N})$, Tenacidade $(\mathrm{MPa})$, Extensão de Ruptura e Módulo (MPa) das amostras produzidas com resina de poliuretano e reforçada com fibras de algodão. Os valores são dados com desvio padrão e coeficiente de variação.

\begin{tabular}{ccccc}
\hline & $\begin{array}{c}\text { Craga } \\
\text { Máxima } \\
(\mathbf{N})\end{array}$ & $\begin{array}{c}\text { Tensão da Carga } \\
\text { Máxima (MPa) }\end{array}$ & $\begin{array}{c}\text { Extensão de } \\
\text { Ruptura }(\mathbf{m m})\end{array}$ & $\begin{array}{c}\text { Módulo } \\
(\mathbf{M P a})\end{array}$ \\
\hline 1 & 2022,88385 & 20,22884 & 4,46031 & 894,56811 \\
2 & 2076,70424 & 20,76704 & 4,67025 & 895,13473 \\
4 & 1356,61485 & 13,56615 & 4,50006 & 404,05078 \\
8 & 1084,78209 & 10,84782 & 2,99994 & 525,05990 \\
9 & 1550,87700 & 15,50877 & 3,28631 & 794,39131 \\
\hline Média & $\mathbf{1 6 1 8 , 3 7 2 4 1}$ & $\mathbf{1 6 , 1 8 3 7 2}$ & $\mathbf{3 , 9 8 3 3 7}$ & $\mathbf{7 0 2 , 6 4 0 9 6}$ \\
$\begin{array}{c}\text { Desvio Padrão } \\
\text { Coeficiente de }\end{array}$ & $\mathbf{4 2 7 , 6 4}$ & $\mathbf{4 , 2 8}$ & $\mathbf{0 , 7 8}$ & $\mathbf{2 2 5 , 2 8}$ \\
Variação & $\mathbf{2 6 , 4 2}$ & $\mathbf{2 6 , 4 2}$ & $\mathbf{1 9 , 5 2}$ & $\mathbf{3 2 , 0 6}$ \\
\hline
\end{tabular}




\subsection{Legislação/Normas ABNT/CETESB - Resíduos Sólidos}

\section{GERAIS}

NBR 10004/04 - Resíduos Sólidos - Classificação

NBR 10005/04 - Procedimento para obtenção de extrato lixiviado de resíduos sólidos

NBR 10006/04 - Procedimento para obtenção de extrato solubilizado de resíduos sólidos

NBR 10007/04 - Amostragem de resíduos sólidos

NBR ISO/IEC 17025/05 - Requisitos gerais para a competência de laboratórios de ensaio e calibração

NBR 10703/89 - Degradação do Solo - Terminologia

NBR 12988/93 - Líquidos livres - Verificação em amostra de resíduos

Decreto Estadual N. 8.468 de 8 de setembro de 1976 - dispõe sobre a prevenção e o controle da poluição do meio ambiente.

Lei Estadual N. 997 de 31 de maio de 1976 - dispõe sobre o controle da poluição do meio ambiente.

Lei Estadual N. 12.300 de 16 de março de 2006 - institui a política estadual de resíduos sólidos e define princípios e diretrizes.

Lei Nacional N. 12.305 de 02 de agosto de 2010 - Política Nacional de Resíduos Sólidos - institui a política nacional de resíduos sólidos e define princípios e diretrizes.

\section{ATERROS SANITÁRIOS/INDUSTRIAIS}

NBR 8418/83 - Apresentação de projetos de aterros de resíduos industriais perigosos - procedimento NBR 10157/87 - Aterros de resíduos perigosos - critérios para projeto, construção e operação - procedimento NBR 8419/92 - Apresentação de projetos de aterros sanitários de resíduos sólidos urbanos - procedimento NBR 13896/97 - Aterros de resíduos não perigosos - Critérios para Projeto, Implantação e Operação - procedimento NBR 12553/03 - Geossintéticos - terminologia 
NBR 15495-1/07 - Poços de monitoramento de águas subterrâneas em aquíferos granulares - Parte 1: Projeto e construção

Resolução CONAMA N. 1 de 23 de janeiro de 1986 - disciplina o EIA/RIMA exigências, conteúdo, elaboração, responsabilidades e audiência pública.

Resolução CONAMA N. 396 de 03 de abril de 2008 que dispõe sobre a classificação e diretrizes ambientais para o enquadramento das águas subterrâneas e dá outras providências.

Resolução SMA N. 42 de 29 de dezembro de 1994 - aprova procedimentos de análise de EIA/RIMA no âmbito da Secretaria do Meio Ambiente.

Resolução SMA N. 51 de 25 de julho de 1997 - dispõe sobre a exigência ou dispensa de Relatório Ambiental Preliminar - RAP para os aterros sanitários e usinas de reciclagem e compostagem de resíduos sólidos domésticos operados por municípios.

Resolução SMA N. 54 de 30 de novembro de 2004 - dispõe sobre procedimentos para o licenciamento ambiental no âmbito da Secretaria do Meio Ambiente.

\section{ARMAZENAMENTO/TRANSPORTE}

NBR 12235/92 - Armazenamento de resíduos sólidos perigosos - procedimento NBR 11174/90 - Armazenamento de resíduos classes II - não inertes e III inertes - procedimento

NBR 13221/07 - Transporte terrestre de resíduos

Decreto Federal N. 875 de 19 de julho de 1993 - promulga o texto da convenção sobre o controle de movimentos transfronteiriços de resíduos perigosos e seu depósito.

Resolução CONAMA N. 23 de 12 de dezembro de 1996 - dispõe sobre o movimento transfronteiriço de resíduos.

Decreto Federal N. 4.581 de 27 de janeiro de 2003 - promulga a emenda ao anexo I e adoção dos anexos VIII e IX à Convenção de Basiléia sobre o controle do movimento 3 transfronteiriço de resíduos perigosos e seu depósito. 


\section{DIVERSAS}

NBR 13741/96 - Destinação de bifenilas policloradas - procedimento

NBR 8371/05 - Ascarel para transformadores e capacitores - características e riscos

NBR 13882/05 - Líquidos isolantes elétricos - deteminação do teor de bifenilas policloradas (PCB)

NBR 13968/97 - Embalagem rígida vazia de agrotóxico - procedimentos de lavagens

NBR 14719/01 - Embalagem rígida vazia de agrotóxico - destinação final da embalagem lavada - procedimento

NBR 14935/03 - Embalagem vazia de agrotóxico - Destinação final de embalagem não lavada - procedimento.

NBR 14283/99 - Resíduos em solos - determinação da biodegradação pelo Método respirométrico

Norma CETESB P4.230/99 - Aplicação de lodos de sistemas de tratamento biológico em áreas agrícolas - critérios para projeto e operação (Manual Técnico)

Norma CETESB P4.233/99 - Lodos de curtumes - critérios para o uso em áreas agrícolas e procedimentos para apresentação de projetos (Manual Técnico)

Norma CETESB P4.263/03 - Procedimento para utilização de resíduos em fornos de produção de clínquer

Norma CETESB P4.231/06 - Vinhaça - critérios e procedimentos para aplicação no solo agrícola.

Norma CETESB L1.022/07 - Utilização de produtos biotecnológicos para tratamento de efluentes líquidos, resíduos sólidos e recuperação de locais contaminados

Portaria Interministerial MINTER/MIC/MME N. 19 de 29 de janeiro de 1981 proíbe a implantação de processos que tenham como finalidade principal a produção de bifenil policlorados - PCBs

Instrução Normativa SEMA/STC/CRS N. 1 de 10 de junho de 1983 - disciplina as condições a serem observadas no manuseio, armazenamento e transporte de bifenilas policloradas PCB's e ou resíduos contaminados com PCB's. 
Resolução CONAMA N. 19 de 19 de setembro de 1994 - autoriza, excepcionalmente, a exportação de resíduos perigosos, contendo bifenilas policloradas PCB's.

Lei Estadual N. 12.288 de 22 de fevereiro de 2006 que dispõe sobre a eliminação controlada dos PCBs e dos seus resíduos, a descontaminação e da eliminação de transformadores, capacitores e demais equipamentos elétricos que contenham PCBs, e dá providências correlatas.

Lei Federal N. 7.802 de 11 de julho de 1989 - dispõe sobre a pesquisa, a experimentação, a produção, a embalagem e rotulagem, 0 transporte, 0 armazenamento, a comercialização, a propaganda comercial, a utilização, a importação, a exportação, o destino final dos resíduos e embalagens, o registro, a classificação, o controle, a inspeção e a fiscalização de agrotóxicos, seus componentes e afins, e dá outras providências.

Decreto Federal N. 4.074 de 4 de janeiro de 2002 - regulamenta a Lei N. 7.802, de 11 de julho de 1989, que dispõe sobre a pesquisa, a experimentação, a produção, a embalagem e rotulagem, o transporte, o armazenamento, a comercialização, a propaganda comercial, a utilização, a importação, a exportação, o destino final dos resíduos e embalagens, o registro, a classificação, o controle, a inspeção e a fiscalização de agrotóxicos, seus componentes e afins, e dá outras providências.

Resolução CONAMA N. 334 de 03 de abril de 2003 - dispõe sobre os procedimentos de licenciamento ambiental de estabelecimentos destinados ao recebimento de embalagens vazias de agrotóxicos.

Lei Estadual N. 4.002 de 05 de janeiro de 1984. - dispõe sobre a distribuição e comercialização de produtos agrotóxicos e outros biocidas no território do Estado de São Paulo.

Resolução SMA N. 7 de 31 de janeiro de 2006 - dispõe sobre o licenciamento prévio de unidades de recebimento de embalagens vazias de agrotóxicos, a que se refere a Lei Federal n. 7.802, de 11.07.89, parcialmente alterada pela Lei n. 9.974, de 06.06.00, e regulamentada pelo Decreto Federal n. 4.074, de 04.01.02.

Resolução CONAMA N. 264 de 26 de agosto de 1999 - aplica-se ao licenciamento de atividades de reaproveitamento de resíduos sólidos em fornos rotativos de produção de clínquer. 
Resolução CONANA N. 313, de 29 de outubro de 2002 - que dispõe sobre o Inventário Nacional de Resíduos Sólidos Industriais.

Resolução CONAMA N. 348 de 16 de agosto de 2004 - altera a Resolução CONAMA n. 307, de 5 de julho de 2002, incluindo o amianto na classe de resíduos perigosos.

Resolução CONAMA N. 362 de 23 de junho de 2005 - estabelece diretrizes para o recolhimento e destinação de óleo lubrificante usado ou contaminado.

Resolução CONAMA N. 375 de 29 de agosto de 2006 - define critérios e procedimentos, para o uso agrícola de lodos de esgoto gerados em estações de tratamento de esgoto sanitário e seus produtos derivados, e dá outras providências.

Resolução SMA N. 39 de 21 de julho de 2004 - estabelece as diretrizes gerais à caracterização do material a ser dragado para o gerenciamento de sua disposição em solo.

Decisão de Diretoria CETESB N. 152/2007/C/E de 08 de agosto de 2007 que dispõe sobre procedimentos para gerenciamento de areia de fundição. 